CAMILA DE JESUS MELLO GONÇALVES

\title{
A TRANSEXUALIDADE SOB A ÓTICA DOS DIREITOS HUMANOS: UMA PERSPECTIVA DE INCLUSÃO
}

Tese de doutorado

Orientador: Professor Titular Celso Lafer

Faculdade de Direito da Universidade de São Paulo

São Paulo

2012 
Esta tese é carinhosamente dedicada:

Ao meu pai, Marcos Peixoto Mello Gonçalves, de quem herdei o gosto pela indagação filosófica.

À minha mãe, Ana Maria Oliveira de Jesus, cuja generosidade e eterna preocupação com o outro serviram de inspiração.

Ao Mario Ernesto Humberg, em agradecimento pela ajuda no recolhimento de notícias envolvendo transexuais nos últimos três anos.

Aos meus filhos Daniel e Manuela, sempre...

Ao Claudio Godoy, com quem tenho a imensa alegria de dividir a vida, especialmente agradeço o incentivo, a paciência e a disponibilidade para trocar ideias no desenvolvimento do trabalho. 


\section{AGRADECIMENTO}

Ao professor Celso Lafer, pelo voto de confiança, apoio e orientação com que sempre pude contar, desde o mestrado, sem os quais esta tese certamente não existiria. 


\section{RESUMO}

Os transexuais são pessoas que se identificam com o gênero oposto ao seu sexo biológico: homens que acreditam e se comportam como se fossem mulheres, e vice-versa. Tal identificação gera um desconforto ou sentimento de inadequação em relação ao próprio corpo, com sofrimento significativo e um desejo de viver e de ser aceito como pessoa pertencente ao outro sexo. Com base nessa crença, promovem alterações em seus corpos, aproximando-os da aparência própria ao seu gênero de identificação.

Cria-se, então, uma contradição entre a imagem e modo de vida da pessoa e seu estado civil, gerando constrangimentos que dificultam o gozo dos direitos civis, econômicos, sociais e culturais.

A violência e discriminação dirigidas às pessoas transexuais ao redor do mundo têm sido denunciadas perante os órgãos internacionais da Organização das Nações Unidas e da Organização dos Estados Americanos. Diante dos fatos, tais órgãos recomendaram o levantamento de dados e a pesquisa interna, no âmbito de cada país, em busca de soluções jurídicas às questões de identidade suscitadas pelos transexuais.

No Brasil, há especial interesse na questão, visto que o País permite a realização da cirurgia de transgenitalização desde 1997, atualmente nos moldes da Resolução $n^{\circ}$ 1.955/2010, do Conselho Federal de Medicina, sem que haja previsão legal quanto aos respectivos efeitos jurídicos.

A falta de legislação contribui para a invisibilidade dos transexuais como vítimas de exclusão, tornando relevantes as contribuições doutrinária e jurisprudencial para a implementação de seus direitos humanos.

Nesse contexto, a partir das concepções moral e jurídica de identidade e da essencialidade do seu reconhecimento social para a preservação da dignidade da pessoa humana, propõe-se a mudança do nome e do sexo, no estado civil da pessoa, como forma de inclusão do transexual, pela tutela de sua identidade de gênero.

Palavras-chave: Transexual - direitos humanos personalidade - identidade de gênero ou sexual 


\begin{abstract}
The transsexuals are people who identify themselves with the opposite gender to their biological sex: men who believe and behave like they were women and vice versa. Such identification generates an inconvenience or a feeling of inadequacy concerning their own body, with a meaningful suffering and desire of living and being accepted as anyone belonging to the other sex. They make changes in their own bodies, based on this belief, getting close to the appearance itself related to the gender of identification.

As a result, it's created a contradiction between the image and the person's way of life and his/her marital status, making embarrassments which raise difficulties for the fruition of civil, economy, social and cultural rights.

The violence and discrimination addressed to transsexual people throughout the world have been denounced before the international organizations of the United Nations and the Organization of American States. Accordingly to the facts, these organizations have recommended the data survey and in-house research, in the range of each country, in order to find juridical solutions to the identity questions raised by the transsexuals.

In Brasil, there is special interest on the question, considering the country allows the realization of transgenitalization surgery since 1997, currently according to the Resolution $\mathrm{n}^{\circ} 1.955 / 2010$, from the Medicine Federal Council, with no legal prediction related to the respective juridical effects.

The lack of legislation contributes to the invisibility of the transsexuals as victims of exclusion, becoming relevant the doctrinaire and jurisprudential contribution for the implementation of their human rights.

Inside this context, from the moral and juridical conceptions of identity and the essentiality of its social recognition for the maintenance of human being dignity, it's proposed a change on the name and sex, in the person's marital status, as a manner of inclusion of the transsexual, by the tutelage of his/her gender identity.
\end{abstract}

Key words - transsexual - human rights - personality - gender or sexual identity 


\section{RÉSUMÉ}

Les transsexuels, ce sont des indivudus qui s'identifient au genre opposé à leur sexe biologique: des hommes qui se voient comme des femmes et qui se comportent comme des femmes, et vice-versa. Une telle identification provoque un malaise ou un sentiment d'inadéquation par rapport à leur corps, avec une souffrance significative et le désir de vivre et d'être accepté comme appartenant à l'autre sexe. À partir de ce fait, ces individus cherchent à promouvoir des altérations sur leur corps, en les approchant d'une apparence propre à leur genre d'identification.

Il se crée alors une contradiction entre l'image et le mode de vie de la personne et son état civil, engendrant des contraintes qui rendent difficiles la jouissance des droits civils, économiques, sociaux et culturels.

La violence et la discrimination adressées à des personnes transsexuelles autour du monde ont été dénoncées auprès des organismes internationaux de l'Organisation des Nations Unies et de l'Organisation des États Américains. Face à ces faits, ces organismes ont recommandé un relevé des données et une enquête interne dans le cadre de chaque pays, à la recherche de solutions juridiques aux questions d'identité suscitées par les transsexuels.

Au Brésil il y a un intérêt particulier porté à cette question, vu que le Pays permet la réalisation de la transgénitalisation depuis 1997, à présent sur le modéle de la Résolution n. 1.955/2010, du Conselho Federal de Medicina (Conseil Fédéral de Médecine), sans qu'il y ait de prévision légale par rapport aux effets juridiques respectifs.

Le manque de législation contribue à l'invisibilité des problèmes des transsexuels tels que l'exclusion, rendant importantes les contributions doctrinaires et de jurisprudence pour la mise en place de leurs droits.

Dans ce contexte, à partir des conceptions morales et juridiques de l'identité et de l'essentialité de leur reconnaissance sociale pour la préservation de la dignité de la personne humaine, est proposé le changement de prénom et du sexe sur l'état civil de la personne, comme forme d'inclusion sociale du transsexuel, par la tutelle de son identité de genre.

Mots-clé: Transsexuel - droits de l'homme - personnalité identité de genre ou sexuelle 


\section{SUMÁRIO}

Introdução - p. 12.

\section{I) A DIGNIDADE DA PESSOA, OS DIREITOS HUMANOS E A TRANSEXUALIDADE}

1) A dignidade da pessoa humana no direito natural e no direito positivo -

p. 15

2) A especificação do sujeito protegido para a concretização da dignidade: a pessoa transexual - p. 18

3) A proposta metodológica para tornar concreto o princípio da dignidade da pessoa humana em relação aos transexuais - p. 21

4) Limitação do objeto - p. 22

\section{II) A BIOÉTICA E OS DIREITOS HUMANOS}

1) O princípio da dignidade da pessoa humana: uma intersecção entre o direito e a reflexão bioética - p. 26

2) Bioética: conceito e objeto - p. 28

3) Princípios da bioética - p. 30

a) O princípio da autonomia - p.31

a.1) O princípio da autonomia em pesquisa com seres

humanos - p. 33

b) O princípio da beneficência - p. 35

c) O princípio da não-maleficência - p. 35

d) O princípio da justiça - p. 35

e) Outros paradigmas para a reflexão bioética - p. 35

4) O Princípio Responsabilidade de Hans Jonas e a transexualidade

a) Os limites da ética fundada na simultaneidade entre a ação e o resultado, no atual estado da técnica - p. 38

b) Os contornos do Princípio Responsabilidade proposto por

Hans Jonas - p. 40 
c) A bioética e o Princípio Responsabilidade - p. 41

d) Perspectiva crítica: a utilização da técnica como meio de controle social, segundo Hans Jonas - p. 44

5) A bioética e o biodireito - p. 46

6) Nomenclatura:

a) Transexualidade ou transexualismo? - p. 51

b) O que se entende por transexual masculino e feminino - $\mathrm{p}$.

52

7) Transexualidade: conceito e distinções. Transexual primário e secundário - 52

8) Critérios de diagnóstico e formas de tratamento da transexualidade no brasil: normas do conselho federal de medicina e do ministério da saúde - p. 58

9) A pessoa transexual: transexualidade ou transexualidades? - p. 60

10) Transexualidade: questão de identidade de gênero e não de orientação sexual - p. 64

11) Breves noções sobre gênero - p. 66

12) Teorias sobre as causas da transexualidade - p. 69

13) A cirurgia para a mudança de sexo e a dignidade humana: uma alternativa de tratamento a critério do paciente - p. 73

\section{III) FUNDAMENTOS JURÍDICOS PARA A PROTEÇÃO DOS TRANSEXUAIS}

Introdução - p. 72

\section{A) O DIREITO INTERNACIONAL DOS DIREITOS HUMANOS}

1) Nota introdutória - p. 79

2) $\mathrm{O}$ combate à violência e discriminação por identidade de gênero - p. 79

3) Relevância da Resolução $n^{\circ} 17 / 1.9 / \operatorname{Rev} .1$ da ONU e da Resolução $n^{\circ}$ $2653($ XLI-O/11) da OEA - p. 83

\section{B) A LIBERDADE}

1) A liberdade como direito humano fundamental - p. 86

2) Liberdade antiga e moderna. Liberdade positiva e negativa. Liberdade na esfera pública e na esfera privada - p. 87 
3) Liberdade e individualismo: da autodeterminação à autorrealização pessoal - p. 92

4) A autonomia, pela perspectiva filosófica - p. 97

5) A identidade como expressão moral da pessoa - p. 101

6) Direitos de liberdade no ordenamento brasileiro: a vida privada e o livre desenvolvimento da personalidade

a) $\mathrm{O}$ direito à vida privada - p. 104

b) $\mathrm{O}$ direito à vida privada em proteção ao transexual - p. 109

c) O direito ao livre desenvolvimento da personalidade como

direito autônomo - p. 112

d) Os conteúdos do direito ao livre desenvolvimento da personalidade - p. 114

e) O livre desenvolvimento da personalidade e a transexualidade - p. 115

\section{C) A IGUALDADE}

1) A situação dos transexuais: vítimas de discriminação por motivo de sexo - p. 119

2) Proposta de aplicação do princípio da igualdade para a tutela dos transexuais - p. 122

3) O princípio da igualdade no direito positivo e sua leitura sob o enfoque dos direitos humanos: a tutela da diferença - p. 123

4) A admissão do tratamento diferenciado em nome da igualdade: a existência de razão suficiente (Robert Alexy) ou de correlação lógica e de fundamento constitucional que o justifique (Celso Antônio Bandeira de Mello) - p. 126

5) A luta por reconhecimento na teoria de Axel Honneth: os planos do amor e da solidariedade - p. 131

6) A negativa de reconhecimento no plano jurídico: violação da igualdade e ofensa à dignidade - p. 135

7) A discriminação e o preconceito - p. 139

8) O reconhecimento jurídico da identidade como forma de inclusão - p. 143 


\section{IV) OS DIREITOS DA PERSONALIDADE E A TRANSEXUALIDADE}

Introdução - p. 147

1) Os direitos da personalidade - p. 148

2) O corpo humano: uma unidade material e imaterial - p. 151

a) O direito ao corpo no ordenamento brasileiro - p. 153

b) A cirurgia para a mudança de sexo, à luz do art. 13, do

Código Civil Brasileiro - p. 156

c) O pressuposto da indicação médica para a realização da cirurgia: uma limitação à autonomia? - p. 161

d) O direito ao corpo e a ofensa aos bons costumes - p. 167

3) As pretensões de mudança de nome e sexo - p. 168

a) $\mathrm{O}$ direito ao nome e a possibilidade de alteração do prenome, em consequência da transexualidade - p. 170

b) Breves considerações sobre o estado civil e a possibilidade de alteração do sexo do transexual - p. 173

\section{V) O DIREITO À IDENTIDADE DE GÊNERO OU SEXUAL}

1) A abertura dos direitos da personalidade como emanações da pessoa humana: a possibilidade de identificação de novos direitos - p. 178

2) A identidade no âmbito do direito - p. 180

3) Sexo x identidade de gênero ou sexual - p. 183

4) $\mathrm{O}$ direito à identidade de gênero ou sexual na doutrina - p. 186

5) $\mathrm{O}$ direito à identidade de gênero na jurisprudência da Corte Europeia de Direitos Humanos - p. 189

a) Análise do caso Christine Goodwin contra o Reino Unido p. 190

6) Uma proposta de reconhecimento do direito à identidade de gênero ou sexual independentemente da intervenção cirúrgica para a redesignação do sexo - p. 195

7) A tutela da segurança jurídica e da ordem pública no reconhecimento do direito à identidade de gênero ou sexual - p. 203

8) $\mathrm{O}$ direito à identidade de gênero independentemente da cirurgia de redesignação do sexo, na legislação comparada - p. 206 
9) $\mathrm{O}$ direito à identidade de gênero ou sexual no Brasil: a ação dos Poderes Legislativo, Executivo e Judiciário

a) A regulação da transexualidade pelo Poder Legislativo - p. 210

b) Ações do Poder Executivo: Regulação do uso do nome social e estabelecimento da Política Nacional de Saúde Integral de Lésbicas, Gays, Bissexuais, Travestis e Transexuais (Política Nacional de Saúde Integral - LGBT) - p. 212

c) $\mathrm{O}$ direito à identidade sexual na jurisprudência - p. 215

10) Reflexos do direito à identidade de gênero ou sexual - p. 218

a) O Registro Civil: conteúdo da anotação, forma, efeitos temporais e publicidade - p. 219

a.1) Conteúdo da anotação - p. 220

a.2) Forma para a mudança do prenome e do sexo no

Registro Civil - p. 222

a.3) Efeitos temporais da averbação da mudança de prenome e sexo no assento de nascimento: irretroatividade - p. 223

a.4) A publicidade da averbação da mudança de prenome e sexo no assento de nascimento - p. 224

b) Casamento - p. 233

b.1) a situação do transexual solteiro - p. 233

6.2) a situação do transexual anteriormente casado - $p$.

236

c) Filiação - p. 240

c.1) a possibilidade de ter filhos após o reconhecimento

da identidade sexual - p. 240

c.2) a situação dos filhos anteriores - p. 243

CONCLUSÃO - p. 247 


\section{Introdução}

O transexual é a pessoa que sente pertencer ao gênero oposto, identificando-se com o papel social contrário ao seu sexo biológico.

$\mathrm{Na}$ área do direito, o debate dominante sobre a transexualidade tradicionalmente se refere a aspectos cirúrgicos, relativos à mudança do sexo, sob o enfoque do direito ao corpo.

Em 1997, no Brasil, o Conselho Federal de Medicina editou a primeira regulamentação da cirurgia de transgenitalização, que passou a ser realizada experimentalmente, no âmbito da pesquisa.

A técnica evoluiu, e atualmente se permite a operação de neocolpovulvoplastia nos casos com indicação precisa de transformação do fenótipo masculino para feminino, inclusive em serviços de hospitais particulares, embora a transformação do fenótipo feminino para o masculino ainda seja autorizada apenas a título experimental (art. $2^{\circ}$, da Resolução CFM 1955/2010).

A par dos avanços cirúrgicos e das formas de tratamento da transexualidade ao redor do mundo, a violência e discriminação contra os transexuais têm chamado a atenção dos órgãos internacionais de proteção dos direitos humanos.

No âmbito da ONU e da OEA, verifica-se a preocupação com o levantamento de dados e com a promoção de discussões sobre as melhores formas de proteção dos transexuais pela legislação internacional de direitos humanos e pelos ordenamentos internos de cada país.

Entre nós, com o advento da Constituição Federal de 1988 e da vigência do novo Código Civil a partir de 2003, sob a influência do princípio da dignidade humana e diante da repersonalização do direito civil, abriu-se uma nova perspectiva de estudo. Essa via caracteriza-se pelo deslocamento da discussão do direito ao corpo, que sempre dominou o debate, para o direito ao desenvolvimento e à expansão da personalidade da pessoa transexual.

A reflexão orientou-se pela crença de que o direito possui instrumentos que podem auxiliar no combate à violência e discriminação, ainda que o Brasil careça de lei específica regulamentadora da transexualidade. Trata-se dos princípios e valores que lhe são subjacentes, necessários de serem realizados e tornados efetivos pelo trabalho hermenêutico dos operadores do direito. 
Essa a abordagem que se pretendeu aprofundar, em busca de alternativas de solução jurídica para o conflito de identidade de gênero apresentado pelos transexuais.

A pesquisa iniciou-se pela fixação do objeto e delimitação do tema, no Capítulo I, voltando-se à reflexão bioética sobre os limites da intervenção humana na natureza, no capítulo seguinte. As definições e classificações estabelecidas pelos profissionais da área da saúde e a regulamentação administrativa da transexualidade no Brasil igualmente foram tratadas no Capítulo II.

Em seguida, fixados os conceitos técnicos básicos, ingressou-se na investigação sobre as Recomendações dos Órgãos do Sistema Internacional e dos Sistemas Regionais de proteção e sobre as normas constitucionais brasileiras, concorrentes na promoção dos direitos humanos enunciados nos planos internacional e interno.

No Capítulo III, partiu-se do direito fundamental à liberdade, percorrendo seus respectivos desdobramentos, como o livre desenvolvimento da personalidade e a vida privada. Seguiu-se pelo direito à igualdade, no que toca ao combate à discriminação, ressaltando-se a importância do reconhecimento jurídico, até alcançar os direitos da personalidade, no Capítulo IV.

Do direito civil, foram buscadas lições sobre a tutela do corpo, do nome e do estado, na investigação sobre as hipóteses em que autorizadas as respectivas mudanças.

O último capítulo, propositivo do direito à identidade de gênero ou sexual entre os direitos da personalidade, tratou da tentativa de constribuição para a tutela dos transexuais no Brasil.

Pretendeu-se defender a possibilidade de mudança do nome e do sexo no Registro Civil, a fim de assegurar a correspondência entre a identidade de gênero e a identificação jurídica da pessoa. Sob esse aspecto, enfrentou-se a hipótese de admissão da identidade de gênero independentemente da cirurgia para a modificação dos caracteres sexuais primários, considerando o teor das recentes leis europeias que regulamentaram a mudança de nome e sexo dos transexuais.

A adequação do nome e do sexo civil ao sentir, agir e aparentar que se completam na identidade de alguém foi percebida como singela contribuição, senão para evitar, ao menos para diminuir o constrangimento e a discriminação experimentados pelos transexuais por ocasião de sua identificação perante a sociedade. 
Pelo reconhecimento jurídico da identidade de gênero, ou sexual, definida no exercício da liberdade, espera-se facilitar o compartilhamento da vida pública, alçando a pessoa à condição de efetiva parceira de interação, na implementação da igualdade. Almeja-se, assim, tornar efetiva a dignidade da pessoa transexual. 


\section{I) A DIGNIDADE DA PESSOA, OS DIREITOS HUMANOS E A TRANSEXUALIDADE}

\section{1) A dignidade da pessoa humana no direito natural e no}

direito positivo

A importância que se deu à pessoa individualmente considerada variou no tempo e no espaço, o que revela um componente cultural na compreensão do que hoje se entende por dignidade humana. Marcos históricos devem ser assinalados.

$\mathrm{Na}$ antiguidade clássica, a dignidade da pessoa humana estava relacionada à posição social, variando de acordo com o status do indivíduo, do que resultava a possibilidade de admitir pessoas com maior ou menor dignidade. ${ }^{1}$

Para os estoicos, a dignidade consistia em qualidade que distinguia os humanos dos demais seres, entendida como atributo inerente à natureza humana, intimamente ligada às noções de liberdade pessoal e de igualdade natural entre os homens. ${ }^{2} \mathrm{O}$ estoicismo atribuiu ao indivíduo uma nova dignidade, de alcance universal, ${ }^{3}$ com base na universalidade da natureza. O estoico Panécio contribuiu para o conceito de pessoa, pois, ao fazer uso simbólico da palavra persona (máscara teatral identificadora de cada personagem), distinguiu a qualidade de pessoa como atributo da natureza universal do ser humano, da personalidade própria de cada indivíduo e, assim, colocou pedra fundamental para o edifício dos direitos humanos na era moderna. ${ }^{4}$

Lembra Celso Lafer que o valor da pessoa humana está presente no Velho Testamento, ${ }^{5}$ no qual o homem é assinalado como o ponto culminante da criação, moldado à imagem e semelhança de Deus.

No mundo romano antigo, a partir dos estudos de Cícero, a dignidade adquire um duplo significado: um sentido moral, baseado na posição ocupada pelo homem na hierarquia da natureza, como único animal racional; e um sentido

\footnotetext{
${ }^{1}$ SARLET. Ingo Wolfgang. Dignidade da pessoa humana e direitos fundamentais na Constituição de 1988. Porto Alegre: Livraria do Advogado Editora, 2010, p. 32.

${ }^{2}$ Idem, mesma página.

3 LAFER, Celso. O caso Ellwanger: anti-semitismo como crime da prática do racismo. In A internacionalização dos Direitos Humanos. Barueri, SP: Manole, 2005, p. 34.

${ }^{4}$ COMPARATO. Fabio Konder. Ética, Direito, Moral e religião no mundo moderno. São Paulo: Companhia das Letras, 2006, p. 117/118.

5 LAFER, Celso. O caso Ellwanger: anti-semitismo como crime da prática do racismo. In A internacionalização dos Direitos Humanos, cit., p. 34.
} 
sociopolítico, vinculado à posição social do indivíduo, e que poderia ser alterado durante a vida. ${ }^{6}$

Durante a Idade Média, Anicio Manlio Severino Boécio introduziu um novo conceito de pessoa como "substância individual de natureza racional", 7 que foi retomado por São Tomás de Aquino, para quem a dignidade humana fundamentava-se não só na ideia de que o homem foi feito à imagem e semelhança de Deus, mas também na capacidade de autodeterminação inerente à natureza humana. ${ }^{8}$

Com o pensamento jusnaturalista dos séculos XVII e XVIII, a concepção de dignidade da pessoa humana passou por um processo de racionalização e laicização, mantendo-se a noção fundamental da igualdade de todos os homens em dignidade e liberdade, como direitos inatos, ${ }^{9}$ negando-se a fundamentação metafísica ou religiosa da dignidade da pessoa. ${ }^{10}$

A tese do contrato social como explicação para a origem do Estado, própria do jusnaturalismo, inspirou a tutela dos direitos humanos pelas Constituições, resultante da preocupação de estabelecer limites ao poder absoluto do soberano. Com a positivação, assegurou-se uma maior segurança e estabilidade aos direitos humanos. $^{11}$

Do ponto de vista da filosofia do direito, igualmente podem ser identificadas influências das diversas escolas, autorizando afirmar que a atual noção de dignidade do ser humano, como valor incondicional, guarda imensa densidade e tradição.

$\mathrm{Na}$ análise de Roberto Andorno, a assimilação de valores na composição da dignidade pode ser assim explicitada: à filosofia grega deve-se a ideia segundo a qual o núcleo mais profundo de cada ser humano é de natureza espiritual, a partir da racionalidade humana; ao cristianismo, a visão do homem como único ser dotado de alma, razão e vontade, à imagem e semelhança de Deus; do renascentismo italiano a ideia do ser humano como microcosmos, ou síntese do universo, superior ao resto da criação; e a Kant, a ênfase na capacidade do ser humano de submeter-se voluntariamente à

\footnotetext{
${ }^{6}$ SARLET. Ingo Wolfgang. Dignidade da pessoa humana e direitos fundamentais na Constituição de 1988, cit., p. 33/34.

${ }^{7}$ Idem, p. 34.

${ }^{8}$ Idem, mesma página.

9 LAFER, Celso. O caso Ellwanger: anti-semitismo como crime da prática do racismo. In A internacionalização dos Direitos Humanos, cit., p. 35.

${ }^{10}$ SARLET. Ingo Wolfgang. Dignidade da pessoa humana e direitos fundamentais na Constituição de 1988, cit., p. 35.

11 LAFER, Celso. O caso Ellwanger: anti-semitismo como crime da prática do racismo. In A internacionalização dos Direitos Humanos, cit., p. 36.
} 
lei moral, captada pela razão, acrescentada da noção do ser humano com um fim em si mesmo, a impedir sua instrumentalização. ${ }^{12}$

Kant, ao vincular a dignidade à autonomia, entendida como faculdade de determinar a si mesmo e agir conforme essa determinação, contribuiu para o fim do processo de secularização da noção de dignidade. ${ }^{13}$ Cabe mencionar, dada a relevância para a dogmática atual dos direitos humanos, o imperativo categórico de Kant, desdobrado na ideia de que a pessoa deve ser encarada como um fim nela mesma, e nunca como meio, ${ }^{14}$ acrescendo às noções de autonomia e racionalidade uma dimensão axiológica da dignidade. ${ }^{15}$

No plano do Direito, a dignidade humana é princípio reconhecido tanto para os adeptos do Direito Natural, quanto para os defensores do Direito Positivo, incluído nas Constituições e Declarações Internacionais após a Segunda Guerra Mundial.

Para Francisco Amaral, o valor da pessoa humana é anterior e preexistente ao ordenamento e à tutela da personalidade, ${ }^{16}$ atribuindo ao cristianismo a criação e o desenvolvimento da ideia de dignidade humana, acima das circunstâncias políticas que determinavam em Roma os requisitos para o conceito de pessoa. ${ }^{17}$

Roberto Andorno, por sua vez, sustenta que a dignidade corresponde a uma realidade pré-jurídica, que precede e fundamenta o ordenamento em seu conjunto. Nesse sentido, afirma que os direitos fundamentais não constituem concessão da autoridade política que pudesse por ela ser caprichosamente retirada. ${ }^{18}$ Acrescenta que o valor único e incondicional de todo ser humano, independentemente de qualquer qualidade assessória, gera um dever de respeito para com o indivíduo, sem que seja exigível nenhum outro requisito adicional. ${ }^{19}$

Atualmente, a discussão própria da Filosofia do Direito sobre a existência do Direito Natural, ou sobre o reconhecimento de um núcleo de realidade

12 "Liberdade" e "Dignidade" da pessoa: dois paradigmas opostos ou complementares na bioética? In MARTINS-COSTA, Judith e MOLLER, Letícia Ludwig. Bioética e responsabilidade. Rio de Janeiro: Editora Forense, 2009, p. 83/84.

${ }^{13}$ SARLET. Ingo Wolfgang. Dignidade da pessoa humana e direitos fundamentais na Constituição de 1988, cit., p. 37.

${ }^{14}$ KANT, Immanuel. Fundamentação da metafísica dos costumes. Lisboa: Edições 70, 2000, p. 69.

${ }^{15}$ SARLET. Ingo Wolfgang. Dignidade da pessoa humana e direitos fundamentais na Constituição de 1988, cit., p. 39.

${ }^{16}$ AMARAL, Francisco, Direito Civil, p., 287.

${ }^{17}$ Idem, p., 289.

18 "Liberdade" e "Dignidade" da pessoa: dois paradigmas opostos ou complementares na bioética? In MARTINS-COSTA, Judith e MOLLER, Letícia Ludwig. Bioética e responsabilidade, cit., p. 81.

${ }^{19}$ Idem, p. 82. 
jurídica anterior e independente da vontade humana, inerente à pessoa e à sociedade, não altera a obrigação de observância e o dever de respeito aos Direitos Humanos, em razão de sua incorporação aos ordenamentos nacionais e internacionais.

Como anota Celso Lafer, a positivação dos direitos humanos resulta da integração de valores percebidos, no curso da história, como essenciais para a boa convivência coletiva. Destaca o autor os seguintes valores: a liberdade e pluralidade do pensamento, provindos da Grécia; a consciência do valor autônomo do Direito, de Roma; o valor da igualdade baseada na natureza humana, independentemente de invólucros políticos e sociais, próprio do Cristianismo; a distribuição e a limitação do poder, advindos do liberalismo; e o valor da igualdade de acesso aos bens e serviços, como contribuição do socialismo. $^{20}$

Assim, sem ingressar no mérito da discussão sobre a existência de direitos preexistentes ao ordenamento, certo é que a dignidade da pessoa humana acabou incorporada ao direito positivo, no pós Segunda Guerra Mundial, notando-se uma ligação jurídico-positiva entre direitos fundamentais e dignidade da pessoa humana que, na retrospectiva de Jorge Miranda, "surge em resposta aos regimes que $<$ tentaram sujeitar e degradar a pessoa humana> (preâmbulo da Constituição Francesa de 1946); quando se proclama que a <dignidade da pessoa humana é sagrada> (art. $1^{\circ}$ da Constituição Alemã de 1949)",; fazendo-se presente também no preâmbulo e no art. $1^{\circ}$, da Declaração Universal: "Todos os seres humanos nascem livres e iguais em dignidade e em direitos. Dotados de razão e de consciência devem agir uns para com os outros em espírito de fraternidade". ${ }^{22}$

\section{2) A especificação do sujeito protegido para a concretização}

\section{da dignidade: a pessoa transexual}

Pela etapa de especificação inserida no processo de afirmação dos direitos humanos, identificam-se categorias de sujeitos passíveis de proteção, com base em características concretas como o gênero, por exemplo. De acordo com Bobbio, a proteção do ser humano em abstrato vai se especificando na proteção de categorias de seres humanos vulneráveis, à semelhança do que ocorreu com o direito à liberdade, cuja ideia

${ }^{20}$ LAFER, Celso. O cinqüentário da declaração universal. A tutela dos direitos humanos no plano internacional no limiar do século XXI: resistência e razoabilidade. In Comércio, Desarmamento, Direitos Humanos. São Paulo: Paz e Terra, 1999, p. 182/183.

${ }^{21}$ MIRANDA, Jorge. Manual de Direito Constitucional. Tomo IV. Coimbra: Coimbra Editora, 2008, p. 195.

${ }^{22}$ Idem, p. 198/199. 
abstrata foi progressivamente sendo concretizada especificadamente nas liberdades de opinião, de consciência, de imprensa, de reunião, de associação. ${ }^{23}$

Daí a aprovação de diversas Declarações no âmbito do Direito Internacional, para a proteção de grupos específicos, como os refugiados e as mulheres, por exemplo. No campo dos direitos sexuais, entre os quais se inclui a temática da identidade de gênero do transexual, ${ }^{24}$ ainda não foi adotada nenhuma Declaração de Direitos pela ONU, ${ }^{25}$ o que inspira o aprofundamento da reflexão.

O princípio da dignidade humana encontra-se insculpido nas Declarações Internacionais e nas Constituições Modernas ocidentais, consistindo em valor a ser observado na interpretação e aplicação do direito.

A insuficiência da generalidade e abstração da "pessoa universal" idealizada na norma tornou necessária a especificação do sujeito protegido, bem como o desenvolvimento dos direitos que lhe são próprios, em busca da efetiva concretização da dignidade. De fato, afirmar a dignidade humana, quer como realidade pré-jurídica para aqueles que a admitem, quer abstratamente na norma, não se mostrou suficiente para a tutela de direitos da pessoa transexual, como se demonstrará.

Os transexuais não compõem um número elevado. De acordo com pesquisa francesa realizada em 2001, correspondem a um em trinta mil homens e a uma em cem mil mulheres. ${ }^{26}$ No Brasil, pesquisa mais recente não encontrou resultado substancialmente discrepante. Trabalho publicado em 31/10/2006, ${ }^{27}$ com base em pesquisa do Programa de Transtorno de Identidade de Gênero do Hospital das Clínicas de Porto Alegre, indica que um em cada quarenta mil homens e uma em cada cem mil mulheres é transexual, suspeitando-se da existência de distorção desses números, atribuível ao medo dos transexuais e ao preconceito da sociedade. ${ }^{28}$

\footnotetext{
${ }^{23}$ BOBBIO, Norberto. A era dos direitos. In A era dos direitos. Tradução de Carlos Nelson Coutinho. Rio de Janeiro: Campus, 1992, p. 62.

${ }^{24}$ De acordo com a Comissão de Direitos Humanos de Ontário, no Canadá, a proibição de discriminação por identidade de gênero está incluída na proibição de discriminação por motivo de sexo. In: Www.ohrc.on.ca/en/issues/gender_identity, acesso em 25/09/2011.

${ }^{25}$ Desde 2008, encontram-se abertas para assinaturas na ONU a proposta das Nações Unidas sobre orientação sexual e identidade de gênero, de iniciativa holandesa e francesa, apoiada pela União Europeia, e outra declaração em sentido oposto, proposta pela Liga Árabe. Nenhuma delas foi oficialmente adotada pela Assembleia Geral da ONU.

${ }^{26}$ CHILAND, Colette. O transexualismo. Tradução de Maria Stela Gonçalves. São Paulo: Edições Loyola, 2008 , p. 105.

${ }^{27}$ Publicação on line, Arch Sex Behav (2006) 35:711-715 DOI 10.1007/s10508-006-9074-y.

${ }^{28}$ LOBATO, Maria Inês; Koff, Walter José; Manenti, Carlo; Seger, Débora da Fonseca; Salvador, Jaqueline; Fortes, Maria da Graça Borges; Petry, Analídia Rodolpho; Silveira, Esalba; Henriques, Alexandre Annes. Follow-Up of Sex Reassignment Surgery in Transsexuals: a Brazilian Cohort, p. 711.
} 
Sob o ponto de vista da proteção dos direitos humanos, o fato de a transexualidade atingir pequena parcela da população não implica a irrelevância do tema, dentro da perspectiva de que qualquer violação de direitos humanos atinge a humanidade inteira, em consequência da indivisibilidade e da universalidade desses direitos. Acresce que, sem embargo da diminuta expressão numérica em relação à população em geral, existem muitos programas de atendimento aos transexuais espalhados pelo mundo, em virtude das graves consequências da transexualidade e da complexidade da cirurgia para a mudança de sexo, ${ }^{29}$ o que corrobora a necessidade de aprofundamento do estudo, sob a perspectiva dos direitos humanos.

A violência e a discriminação de que são vítimas as pessoas transexuais revelam-se nos trabalhos realizados pelos profissionais de campo que acompanham o cotidiano dessa população.

Como assevera William Siqueira Peres, os processos de estigmatização sofridos pelos transexuais interferem na organização de suas subjetividades, construídas com base nas relações que estabelecem com os outros e consigo mesmos, ${ }^{30} \mathrm{o}$ que acaba prejudicando o desenvolvimento de suas personalidades sob vários aspectos da vida social. Já na infância detecta o psicólogo o início das dificuldades, uma vez que a escola não está preparada para o trato com os alunos transexuais, acabando por corporificar a exclusão, por meio da discriminação, expulsão, ou descaso da dor. Lembra o autor que, ao chegar à escola, o aluno já experimentou transtornos na esfera familiar e social e apresenta uma base emocional fragilizada, não possuindo recursos para lidar com a estigmatização e a discriminação, o que gera agressividade e revolta, podendo levar ao abandono da escola. Forma-se, então, um círculo vicioso que, como anota o mesmo autor, contribui para a marginalização, dada a importância do estudo em nossa sociedade. ${ }^{31}$ Nesse contexto, os transexuais estigmatizados e discriminados acabam na prostituição, "empurrados para os espaços de batalha em consequencia da violência estrutural", prejudicados em sua socialização e fadados a um universo existencial bastante restrito. ${ }^{32}$

\footnotetext{
${ }^{29}$ Idem, mesma página.

${ }^{30}$ PERES, Wiliam Siqueira. Cenas de Exclusões Anunciadas: travestis, transexuais, transgêneros e a escola brasileira. In Diversidade Sexual na Educação: problematizações sobre a homofobia nas escolas. (Org) Junqueira, Rogério Diniz. Brasília: Ministério da Educação, UNESCO, 2009, p. 237.

${ }^{31}$ Idem, p. 245.

${ }^{32}$ Idem, p. 246.
} 
No mesmo sentido, constata o sociólogo Richard Miskolci que os transexuais, ao lado dos travestis, pobres, negros, portadores de HIV e efeminados, ocupam a base da respeitabilidade sexual e social, tratando-se de pessoas estigmatizadas. ${ }^{33}$

O quadro que se esboça revela, assim, a acentuada discriminação de que são vítimas os transexuais, levando ao resultado mais grave, da estigmatização e efetiva exclusão. Como anota Julieta Lemaitre Ripoll, professora associada da Faculdade de Direito da Universidade dos Andes, em Bogotá, e diretora do Centro de Pesquisas Sociojurídicas da mesma Universidade, forte na lição de Maria Mercedes Gómez, a discriminação importa em violência dirigida a pessoas consideradas parte da sociedade, mas em posição de subordinação. Desse modo, "o objetivo dessa violência, tanto instrumental quanto simbólica, é manter a subordinação". ${ }^{34}$ Já a exclusão "pretende expulsar do corpo social certos elementos que não podem fazer parte dele", ${ }^{35} \mathrm{o}$ que pode ser apontado como um dos fatores que contribuem para a violação dos direitos humanos das pessoas transexuais.

Sob esse aspecto, vale lembrar que a violência e discriminação de que são vítimas os transexuais no Brasil foi denunciada na audiência realizada em 25 de outubro de 2010, perante a Comissão Interamericana de Direitos Humanos, em seu $140^{\circ}$ período de Sessões, tudo a justificar o interesse na pesquisa sobre formas de inclusão jurídica do transexual.

Constatada a violação de direitos humanos, conclusão necessária é a insuficiência da dignidade humana declarada nas normas internacionais e nacional para assegurar o respeito a essa população. Daí a necessária elaboração de normas protetivas no processo de especificação do sujeito vulnerável, na tentativa de tornar concreta e efetiva a dignidade abstratamente enunciada.

\section{3) A proposta metodológica para tornar concreto o princípio}

\section{da dignidade da pessoa humana em relação aos transexuais}

Como ensina Larenz, os princípios ético-jurídicos, que se distinguem dos demais por seu conteúdo material de justiça, são ideias diretrizes que pressupõem uma atividade legislativa e jurisprudencial, no processo de aplicação da

\footnotetext{
${ }^{33}$ Apud AGUIAR, Joselia. Amores Silenciados. Como a política da elite do século XIX modelou a nossa sexualidade. São Paulo: Revista de Pesquisa FAPESP, nº 174, agosto de 2010, p. 84.

${ }^{34}$ RIPOLL, Julieta Lemaitre. O amor em tempos de cólera: direitos LGBT na Colômbia. Tradução de Pedro Maia Soares. In SUR - Revista Internacional de Direitos Humanos, v. 6, n. 11, dez 2009, p. 87.

35 Idem, mesma página.
} 
norma, ${ }^{36}$ o que se estende ao princípio da dignidade. Nesse sentido, não basta a enunciação do valor para sua realização pela norma, fazendo-se necessária atividade ulterior que torne efetivo o princípio.

A metodologia que se procurou observar, destarte, parte da constatação da insuficiência da declaração do princípio da dignidade humana e, portanto, da necessidade de construir fundamentos que auxiliem sua concretização, a fim de tornar efetiva sua aplicação. Assume-se a dificuldade de operar com princípios em razão de sua generalidade, tornando necessária "uma concretização através de sub-princípios e valores singulares, com conteúdo material próprio", ${ }^{37}$ encontrando-se, nos princípios da liberdade e igualdade e seus desdobramentos, os caminhos para a implementação da dignidade que se pretende alcançar por meio do reconhecimento do direito à identidade sexual.

A partir daí, inspirada pela ideia de Hannah Arendt, difundida por Celso Lafer, de que "o primeiro direito humano é o direito a ter direitos" com o presente estudo, buscar fundamentos jurídicos para a efetivação da dignidade no plano da realidade, tornando concretos os direitos humanos universalmente enunciados nas normas.

Para tanto, e dada a amplitude das possibilidades de concretização da dignidade, necessária a definição do ângulo pelo qual se pretende abordar o tema.

\section{4) Limitação do objeto}

$\mathrm{Na}$ presente tese, circunscreve-se o objeto do estudo aos direitos civis, sob as perspectivas da liberdade e da igualdade, pois a investigação está voltada ao reconhecimento do direito ao nome e à identidade de gênero da pessoa transexual, entre os direitos da personalidade. A transexualidade, nesses termos, não será aprofundada exclusivamente sob o enfoque do direito ao corpo, propondo-se uma visão que permita a abordagem do tema sob o ângulo dos direitos humanos.

A separação entre os direitos da personalidade, propriamente civis, e os direitos econômicos e sociais é apenas teórica, tanto mais quando o tema da transexualidade envolve uma dimensão de discriminação e exclusão não raro acompanhada

\footnotetext{
${ }^{36}$ LARENZ, Karl. Metodologia da Ciência do Direito. Tradução de José Lamego. $3^{\text {a }}$ ed. Lisboa: Calouste Gulbenkian, 1997, p. 599.

${ }^{37}$ CANARIS, Claus-Wilhelm. Pensamento Sistemático e Conceito de Sistema na Ciência do Direito. Tradução de Menezes Cordeiro. 2a ed. Lisboa: Calouste Gulbenkian, 1996, p. 88.

${ }^{38}$ LAFER, Celso. A Reconstrução dos Direitos Humanos: um diálogo com o pensamento de Hannah Arendt. São Paulo: Companhia das Letras, 2003, p. 153/154.
} 
da negativa de acesso aos bens de mercado. De fato, a experiência mostra que a intensidade da discriminação do transexual varia de acordo com outros fatores de exclusão, como a pobreza, a cor da pele, comportamento e idade. ${ }^{39}$ E, como alerta Axel Honneth ao tratar da luta por reconhecimento motivada pelo desrespeito, as relações de estima social "estão acopladas de forma indireta com os padrões de distribuição de renda", de forma que "os confrontos econômicos pertencem constitutivamente a essa forma de luta por reconhecimento". 40

Nesses termos, deixar de lado a discussão econômica ao tratar de tema de direitos humanos, por característica indivisíveis, pode resultar no insucesso ou na frustração do objetivo de inclusão que se busca alcançar. Como alerta Richard Rorty (Achieving our Country - Harvard University Press, 1998), citado por Zygmunt Bauman, a tendência a "não falar sobre dinheiro" na defesa de causas relacionadas a grupos ou categorias, leva à incapacidade de engajamento na luta política, para o que seria necessário "falar mais sobre dinheiro, ainda que à custa de falar menos sobre estigma". 41

Ocorre que, como alerta Nancy Fraser, a injustiça decorrente da má distribuição dos bens e a injustiça provocada por padrões institucionalizados de valores culturais na sociedade, ainda que não necessariamente se excluam e possam concorrer uma para outra, são combatidas por diferentes políticas, de distribuição e de reconhecimento, respectivamente, o que permite, salvo melhor juízo, o enfrentamento das injustiças em separado.

No que toca à economia, o gênero estabelece distinções entre o trabalho remunerado e o trabalho doméstico, assim como diferente acesso a cargos e remunerações, reclamando uma justiça redistributiva. Sob a perspectiva do status, diversamente, a injustiça provocada pelo gênero reclama políticas de reconhecimento, voltadas a combater danos que são injustiças de reconhecimento, como a violência sexual, a violência doméstica, a negação da integridade corporal, a liberdade reprodutiva e de

\footnotetext{
${ }^{39}$ PERES, Wiliam Siqueira. Cenas de Exclusões Anunciadas: travestis, transexuais, transgêneros e a escola brasileira. In Diversidade Sexual na Educação: problematizações sobre a homofobia nas escolas. (Org) Junqueira, Rogério Diniz. Brasília: Ministério da Educação, UNESCO, 2009, p. 260.

${ }^{40}$ HONNETH, Axel. Luta por reconhecimento. A gramática moral dos conflitos sociais. Tradução de Luiz Repa. São Paulo: Ed. 34, 2a Ed., 2009, p. 208.

${ }^{41}$ Identidade: entrevista a Benedetto Vecchi. Tradução de Carlos Alberto Medeiros. Rio de Janeiro: Jorge Zahar, 2005, p. 42/43.
} 
autodeterminação sexual, a estereotipagem, a reificação, a perseguição e depreciação na vida cotidiana, entre outros. ${ }^{42}$

Assentada a distinção entre a política de redistribuição e a política de reconhecimento no combate à injustiça, pode-se adiantar que o tema será aprofundado sob a perspectiva do status e, portanto, da violação de direitos dirigida à pessoa transexual em razão da divergência entre seu nome civil e sexo biológico, de um lado, e seu nome social e identidade de gênero, de outro, ensejando a privação de direitos e a diminuição do status dela decorrente, a reclamar políticas de reconhecimento, especificamente no âmbito jurídico.

Mesmo porque, ainda que se reconheça a dificuldade de melhoria da situação dos transexuais sem que haja também um esforço em lhes proporcionar maior acesso à educação, ao mercado e aos bens de consumo, a tutela da pessoa contra a discriminação em si e sem conteúdo econômico direto é possível e inclusive prevista, por exemplo, no direito norte-americano, por meio da cláusula de igual proteção.

Na lição de Eduardo Appio, “A cláusula de igual proteção não tem a finalidade de propiciar as mesmas condições materiais para todos os cidadãos ou o mesmo padrão básico de vida (mínimo existencial) para todos os indivíduos. Seu escopo é certo e determinado, ou seja, combater a discriminação em suas mais diversas variantes", estabelecendo "que nenhuma pessoa será tratada com menosprezo pelo Estado, como decorrência de características que a definem em sua singularidade". ${ }^{43}$

E, como anota Gustavo Zagrebelsky, o direito constitucional europeu contemporâneo aproximou-se do direito norte-americano, ao reconhecer direitos individuais originários, independentes e protegidos contra a lei, ${ }^{44}$ o que igualmente se aplica ao direito brasileiro.

No mesmo sentido, acrescenta Sueli Dallari que o edifício dos direitos humanos inclui uma estrutura de proteção que abarca tanto os interesses mais amplos da comunidade quanto aqueles mais imediatamente ligados às pessoas que nela

\footnotetext{
${ }^{42}$ FRASER, Nancy. Redistribuição, Reconhecimento e Participação: Por uma Concepção Integrada de Justiça. In Sarmento, Daniel, Ikawa, Daniela e Piovesan, Flavia. Igualdade, Diferença e Direitos Humanos. Rio de Janeiro: Lúmen Juris, 2008, p. 175.

${ }^{43}$ APPIO, Eduardo. Direito das minorias. Editora Revista dos Tribunais, 2009, p. 217.

${ }^{44}$ ZAGREBELSKY, Gustavo. El derecho dúctil. Ley, derechos, justicia. Tradução de Marina Gascón. Madri: Trotta, $5^{\text {a }}$ ed., 2003, p. 54.
} 
vivem, ${ }^{45}$ podendo-se admitir o aprofundamento dos direitos humanos civis, individuais, subjetivos, íntimos e inerentes à personalidade em si, ao lado dos direitos políticos, econômicos e sociais.

Nesse contexto, a necessária limitação do objeto torna-se viável e, longe de significar desconsideração à relevância dos direitos sociais e econômicos, resulta do critério metodológico eleito para a investigação científica sob a perspectiva que se optou por aprofundar, fundada na premissa de que a garantia dos direitos da personalidade é condição para o gozo dos demais direitos humanos. Busca-se, desse modo, propor formas de promoção do respeito à pessoa transexual, a fim de evitar a violação à dignidade decorrente da falta de reconhecimento e da privação de direitos individuais.

Por fim, cabe reiterar que o enfrentamento do tema pelo ângulo dos direitos ligados à personalidade e à subjetividade do transexual não importa a defesa da suficiência do reconhecimento no plano jurídico para a implementação da justiça social. Apenas que, entre as várias formas de luta pela justiça, a do reconhecimento de direitos ao nome e à identidade de gênero, pelo ordenamento, não deve ser desconsiderada, inclusive em razão das consequências da negativa de mudança de gênero e do nome, para o gozo dos direitos econômicos, sociais e culturais.

\footnotetext{
${ }^{45}$ DALLARI, Sueli Gandolfi. A proteção do Direito à intimidade, a Confidencialidade e o Sigilo na Pesquisa em Saúde. In Benevides, Maria Victoria de Mesquita, Bercovici, Gilberto, Melo, Claudinei. Direitos Humanos, Democracia e República: Homenagem a Fábio Konder Comparato - São Paulo: Quartier Latin, 2009, p. 907.
} 


\section{II) A BIOÉTICA E OS DIREITOS HUMANOS}

\section{1) O princípio da dignidade da pessoa humana: uma intersecção entre o direito e a reflexão bioética}

No campo da medicina, o avanço da ciência e da técnica vem crescentemente ampliando as alternativas que se abrem ao indivíduo, desejoso de expandir seu poder e controle sobre a vida e sobre a natureza. Esse desejo é identificado por Habermas, para quem, enquanto a tecnicização da natureza humana for conduzida pela expectativa de obter uma vida mais saudável e mais longa, não haverá empecilhos à aceitação social das novas técnicas. ${ }^{46}$

Supõe-se a conquista do domínio total sobre as coisas e sobre o próprio homem como forma de realização do destino humano, valendo transcrever a reflexão de Hans Jonas: "Somos tentados a crer que a vocação dos homens se encontra no contínuo progresso desse empreendimento, superando-se sempre a si mesmo, rumo a feitos cada vez maiores". 47

Ocorre que a velocidade da mudança e os avanços tecnológicos, ainda que aceitos porque responsivos aos anseios sociais, trazem um risco às sociedades contemporâneas, que passam a ser denominadas como "de risco", realidade essa em que devem ser examinados os aspectos éticos e jurídicos envolvidos no trato da pesquisa em saúde e proteção da intimidade, ${ }^{48}$ pois a tecnologia, "divorciada da ética, conduz à inevitável fratura da humanidade". ${ }^{49}$ Como pondera Sueli Gandolfi Dallari, "Exatamente porque no começo do século XXI a humanidade sabe que não consegue controlar o risco dito "tecnológico", assiste-se ao retorno agressivo do julgamento moral ou disciplinar". 50

Nesse contexto, surge clara a necessidade da existência e atuação de princípios jurídicos com função moderadora, que protejam o homem do risco de violação da própria dignidade e da destruição da vida em consequência da imprevisão dos resultados produzidos pelas novas técnicas.

\footnotetext{
${ }^{46} \mathrm{O}$ futuro da natureza humana. Tradução Karina Jannini. São Paulo: Martins Fontes, 2004, p. 35.

${ }^{47}$ JONAS, Hans. O princípio responsabilidade, p. 43.

${ }^{48}$ DALLARI, Sueli Gandolfi. A proteção do Direito à intimidade, a Confidencialidade e o Sigilo na Pesquisa em Saúde. In Benevides, Maria Victoria de Mesquita, Bercovici, Gilberto, Melo, Claudinei. Direitos Humanos , Democracia e República: Homenagem a Fábio Konder Comparato. São Paulo: Quartier Latin, 2009, p. 908.

${ }^{49}$ COMPARATO, Fabio Konder. Ética: direito, moral e religião no mundo moderno. São Paulo: Companhia das Letras, 2006, p.435.

${ }^{50}$ DALLARI, Sueli Gandolfi. A proteção do Direito à intimidade, a Confidencialidade e o Sigilo na Pesquisa em Saúde. In Benevides, Maria Victoria de Mesquita, Bercovici, Gilberto, Melo, Claudinei. Direitos Humanos , Democracia e República: Homenagem a Fábio Konder Comparato, cit., p. 909.
} 
Para tanto, o princípio da dignidade humana funda a estrutura jurídica protetiva da pessoa, veiculando o sistema normativo e influenciando as áreas de conhecimento que se debruçam sobre a vida humana.

A reflexão bioética, destarte, inspira-se no princípio da dignidade da pessoa humana, expresso na Declaração Universal dos Direitos do Homem, de 1.948 , e no art. $1^{\circ}$, III, da Constituição Brasileira, espraiando-se pelo ordenamento e estendendo-se a todos os sistemas normativos que fixam no homem um ponto de referência, na concretização da função de expansão axiológica, de que trata Celso Lafer. ${ }^{51}$

O princípio da dignidade humana, assim, orienta a atividade humana em pesquisa e o sentido de interpretação das demais normas do sistema jurídico, veiculando o valor da pessoa, cuja positivação pelo legislador tornou de observância obrigatória.

Nesse sentido, o princípio e o valor nele contido acabam por atuar como moderadores do potencial agressivo, desagregador e destrutivo da vontade individual, ${ }^{52}$ respondendo ao anseio de que as respostas do Direito às novas questões não provenham de uma ética meramente formal. ${ }^{53}$

Além disso, o princípio constitucional oferece um critério objetivo para a solução de conflitos entre os valores da ciência e das humanidades, evitando o subjetivismo ou o moralismo e contribuindo para a solução democrática dos conflitos.

O princípio constitucional da dignidade da pessoa humana impede, assim, qualquer construção teórica contrária à dignidade, quer por razões moralistas, quer por ambições científicas, atuando como norte para todos.

Nessa quadra, pode-se afirmar que o princípio da dignidade limita a técnica e traduz a medida da intervenção humana na natureza, estendendo-se para além do direito, às áreas da saúde, reconhecendo a doutrina não só que a dignidade "ilumina e dá sentido à atividade biomédica", 54 mas também que os direitos humanos atuam como verdadeiro paradigma dos bioeticistas, ${ }^{55}$ no pressuposto de que "o sistema dos

\footnotetext{
${ }^{51}$ Filosofia do Direito e princípios gerais. In O que é Filosofia do Direito?, p. 57.

${ }^{52}$ ZAGREBELSKY, Gustavo. El derecho dúctil. Tradução Marina Gascón. Madri: Trotta, p. 94.

${ }^{53}$ COMPARATO, Fabio Konder. O direito como parte da ética. In O que é Filosofia do Direito?, p. 4.

${ }^{54}$ ANDORNO, Roberto. "Liberdade" e "Dignidade" da pessoa: dois paradigmas opostos ou complementares na bioética? In MARTINS-COSTA, Judith e MOLLER, Letícia Ludwig. Bioética e responsabilidade, cit., p. 91.

${ }^{55}$ DINIZ, Maria Helena. O estado atual do biodireito. $4^{\text {a }}$ ed. São Paulo: Saraiva, 2007, p. 16.
} 
direitos humanos vem sendo apropriado pelos cultores da bioética", ${ }^{56}$ exigindo-se a proteção da integridade e da identidade do gênero humano como tarefas da bioética. ${ }^{57}$

O inverso também é verdadeiro, podendo-se vislumbrar o desenvolvimento de temas jurídicos relacionados aos direitos humanos, impulsionados pelas conquistas científicas e técnicas, que trouxeram ameaças à integridade física, intelectual e moral do homem, diante do que a doutrina civilista reconhece um favorecimento ao desenvolvimento dos direitos da personalidade, ${ }^{58}$ apoiado na noção substancial de pessoa e no princípio da dignidade da pessoa humana, que não pode ser entendido em sentido formal, mas, sim, fundado na noção ontológica de pessoa. ${ }^{59}$

Nesse contexto, pode-se apontar a existência de uma relação dialética e complementar entre o direito e o desenvolvimento da técnica, pela qual o princípio da dignidade humana, ao mesmo tempo queserve de norte e limite ao avanço científico, tem seu conteúdo aprofundado e delineado pelas novas descobertas. É dizer, a transformação física da aparência de um homem em uma mulher, e vice-versa, tornada possível pela ciência, força a ampliação do rol de direitos da personalidade, em busca da tutela jurídica dessa nova realidade, percebendo-se um compasso entre o avanço da técnica e a expansão de direitos do homem.

Daí porque Maria Helena Diniz, ao analisar a relação entre a bioética e os direitos humanos, conclui pela existência de íntima ligação, afirmando: "A bioética e o biodireito andam necessariamente junto com os direitos humanos". ${ }^{60}$

Essa a perspectiva do aprofundamento do tema, não sem antes estabelecer alguns conceitos e definições próprios da bioética.

\section{2) Bioética: conceito e objeto}

Na origem, o conceito de bioética estava ligado à preocupação ecológica, em virtude do uso indiscriminado de agrotóxicos, animais em pesquisa, experiências biológicas, poluições aquática, atmosférica e sonora, tratando-se de sentido

\footnotetext{
${ }^{56}$ DALLARI, Sueli Gandolfi. A proteção do Direito à intimidade, a Confidencialidade e o Sigilo na Pesquisa em Saúde. In Benevides, Maria Victoria de Mesquita, Bercovici, Gilberto, Melo, Claudinei. Direitos Humanos , Democracia e República: Homenagem a Fábio Konder Comparato, cit., p. 904.

${ }^{57}$ ANDORNO, Roberto. "Liberdade" e "Dignidade" da pessoa: dois paradigmas opostos ou complementares na bioética? In MARTINS-COSTA, Judith e MOLLER, Letícia Ludwig. Bioética e responsabilidade, cit., p. 82

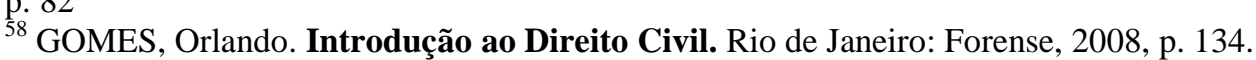

${ }^{59}$ ASCENSÃO, José de Oliveira. Pessoa, Direitos Fundamentais e Direito da Personalidade. In Estudos de Direito da Bioética, José de Oliveira Ascensão (coord), vol III, Almedina, p. 64.

${ }^{60} \mathrm{O}$ estado atual do biodireito, cit., p. 18.
} 
totalmente diverso do atual, em que a bioética é entendida como ética das ciências da vida. $^{61}$

A doutrina atribui a criação da expressão bioética ao americano Van Rensselaer Potter, autor da obra Bioethics:bridge to the future (Bioética: ponte para o futuro), de 1.971, na qual o autor propunha a construção de uma nova disciplina: a bioética.

Segundo Potter, a cultura da ciência baseava-se no conhecimento, e a cultura das humanidades, na sabedoria, resultando a bioética da união do trabalho dos cientistas com o trabalho dos humanistas, destinada a acompanhar o desenvolvimento científico com uma vigilância ética isenta de interesses morais, com preocupações majoritariamente ecológicas.

De lá pra cá, o objeto da bioética ampliou-se, passando a incluir reflexões sobre os problemas éticos derivados das descobertas e das aplicações das ciências biológicas, que muito se desenvolveram na segunda metade do século XX.

Nesse sentido, Berlinguer exemplifica as possibilidades de conhecer e transformar o patrimônio genético das espécies vivas, de vivenciar a sexualidade sem procriação, de procriar sem relações sexuais, de transplantar órgãos e de prolongar artificialmente a vida, como aquisições recentes que provocam reflexões bioéticas, para além das preocupações com o meio ambiente. ${ }^{62}$

REICH (1978) definiu Bioética como o "estudo sistemático da conduta humana, na área das ciências da vida e dos cuidados de saúde, quando se examina esse comportamento à luz dos valores e dos princípios morais". ${ }^{63}$

Na segunda edição da Encyclopedia of bioethics, de 1995, a definição supra deixou de incluir a alusão aos "valores e princípios morais". O autor passou a definir a boética como o "estudo sistemático das dimensões morais das ciências da vida e do cuidado da saúde, utilizando uma variedade de metodologias éticas em um contexto multidisciplinar", adaptando o pluralismo ético atual à área da bioética. ${ }^{64}$

No Dicionário Latino-americano de Bioética, dirigido por Juan Carlos Tealdi, a bioética é definida como "parte da ética que estuda os problemas inerentes à tutela da vida física e, em particular, às implicações éticas das ciências biomédicas”.

${ }^{61}$ DINIZ, Maria Helena. O estado atual do biodireito. São Paulo: Saraiva, 2007, p. 09.

${ }^{62}$ BERLINGUER, Giovanni. Questões de vida (Ética, Ciência, Saúde). Título original "Questioni di Vita: Etica,scienza, salute". Torino, Giulio Einaudi, 1991. Tradução de Maria Patrícia de Sabóia Orrico e Mauro Porru. APCE-HUCITEC-CEBES: Salvador, São Paulo, Londrina: 1993, p.19.

${ }^{63}$ Encyclopedia of bioethics, editada por Stephen G. Post.

${ }^{64}$ DINIZ, Maria Helena. O estado atual do biodireito, cit., p. 10. 
Carla Faralli entende a bioética como uma fronteira da filosofia do direito contemporânea, aberta em razão das transformações rápidas e profundas da sociedade. ${ }^{65}$ Trata-se, na visão da autora, não de uma nova ética ou de nova disciplina, mas de "um conjunto de pesquisas, de discursos e de práticas, geralmente pluridisciplinares, cujo objeto é o esclarecimento ou a solução de questões de caráter ético, suscitadas pelas inovações científicas e tecnológicas que tornaram possível agir sobre fenômenos vitais de maneiras, há algumas décadas, consideradas impensáveis". 66

Na definição de Maria Helena Diniz, bioética é um "conjunto de reflexões filosóficas e morais sobre a vida em geral e sobre as práticas médicas em particular", versando sobre problemas que envolvem conflitos de valores, além de questões materiais e subjetivas de difícil solução. ${ }^{67}$

A par das diversas definições, Berlinguer identifica quatro planos de reflexão bioética: a bioética cotidiana, a bioética deontológica, a bioética legal e a bioética filosófica.

A primeira refere-se aos comportamentos e ideias de cada pessoa diante dos novos conflitos; a segunda, aos códigos morais dos deveres dos profissionais envolvidos com a pesquisa e com o uso das descobertas biomédicas. A bioética legal ou bioius, também denominada biodireito, inclui as normas em sentido amplo, leis e regulamentos destinados a regrar a atividade de pesquisa, editadas e interpretadas pelo Estado.

Por fim, tem-se a bioética filosófica, como o plano da bioética voltado à compreensão dos princípios e valores que estão na base das reflexões e das ações humanas, concluindo: "A riqueza e complexidade do tema estão na interseção destes quatro planos". 68

A partir dessa classificação, pode-se situar este trabalho no âmbito da bioética legal e da bioética filosófica, posto que enfoca as normas relativas à transexualidade, objeto da primeira, e pretende fomentar a reflexão sobre a transexualidade a partir dos valores positivados no ordenamento, corporificados nos princípios da

\footnotetext{
${ }^{65}$ A filosofia do direito contemporânea: temas e desafios. Tradução de Candice Premaor Gullo. São Paulo: 2006 , p. 73.

${ }^{66}$ Idem, p. 74.

${ }^{67}$ DINIZ, Maria Helena. O estado atual do biodireito, cit., p. 11.

${ }^{68}$ BERLINGUER, Giovanni. Questões de vida (Ética, Ciência, Saúde). Título original "Questioni di Vita: Etica,scienza, salute. Torino, Giulio Einaudi, 1991Tradução de Maria Patrícia de Sabóia Orrico e Mauro Porru. APCE-HUCITEC-CEBES: Salvador, São Paulo, Londrina: 1993, p.20.
} 
dignidade, liberdade e igualdade, temas da bioética filosófica, em busca de seus desdobramentos no direito positivo.

O enfoque bioético, destarte, refere-se à reflexão sobre a transformação da vida, que se identifica nos tratamentos e na cirurgia voltados à transformação do corpo do transexual. Inclui refletir também sobre o binômio saúdedoença, considerando a existência de um sofrimento psíquico em um corpo saudável, acompanhado do desejo por intervenções físicas de larga proporção.

Os códigos morais dos profissionais da saúde, assim como o relacionamento entre o homem e o meio ambiente não serão objeto de aprofundamento, sem embargo da relevância do tema, por se tratar de campos da bioética não diretamente relacionados ao tema que se está a desenvolver.

\section{3) Princípios da bioética}

Os primeiros princípios da bioética resultaram das conclusões da Comissão Nacional criada pelo Congresso dos Estados Unidos, com o objetivo de identificar os princípios éticos básicos que deveriam ser observados pelas ciências de comportamento e pela biomedicina, na investigação sobre seres humanos. Os trabalhos iniciaram-se em 1974 e, quatro anos depois, a referida Comissão publicou o Informe Belmont, contendo os princípios da autonomia, da beneficência, e da justiça. ${ }^{69}$

Posteriormente, Tom L. Beauchamp e James F. Childress acrescentaram o princípio da não maleficência, pela publicação da obra Principles of biomedical ethics, em 1979. ${ }^{70}$

\section{3.a) O princípio da autonomia}

O princípio da autonomia, em razão do particular interesse que desperta para o tema da transformação corporal, será objeto de maior aprofundamento.

Esse princípio refere-se à autonomia das pessoas sob uma perspectiva individual. Por isso, compreende-se que não estivesse esboçado no juramento hipocrático, de época marcada pelas noções de universalismo e totalidade, não se falando

\footnotetext{
${ }^{69}$ BARBOZA, Heloisa Helena. Princípios do biodireito, in Novos Temas de Biodireito e bioética. Renovar, p. 55.

${ }^{70}$ Idem, mesma página.
} 
em "autonomia da pessoa" na democracia grega da Antiguidade, fundada na harmonia entre o homem e o cosmos como critérios éticos. ${ }^{71}$

Modernamente, a ideia de pessoa singular e do individualismo como paradigmas da filosofia, a partir do século XVIII, propiciou o desenvolvimento da noção de autonomia, estendida à área da saúde.

Roberto Andorno sustenta a aproximação da autonomia com a liberdade, baseado nos conceitos interno e externo de liberdade: o primeiro corresponde ao livre arbítrio, que supõe a razão humana; e o segundo refere-se à ausência de obstáculos para a realização da ação desejada, ${ }^{72}$ concluindo que, na bioética, a liberdade se expressa pelo termo autonomia, ${ }^{73}$ ou seja, pela possibilidade de tomar a decisão e implementá-la, ainda que de forma a exigir uma abstenção do médico.

Define-o Maria Helena Diniz como "a capacidade de atuar com conhecimento de causa e sem qualquer coação ou influência externa". ${ }^{74}$

O reconhecimento da relevância da vontade livre e racional expressada pelo paciente contribuiu para a superação do paternalismo nas relações médicopaciente, consistindo na "base do novo enfoque das relações entre os profissionais da saúde e os pacientes nas Cartas dos direitos dos doentes", representando a superação da “infantilização do paciente". 75

$\mathrm{Na}$ área da biomedicina e pesquisa, outrossim, tratando-se da saúde física e psíquica do indivíduo, é o interesse e a vontade individual que devem prevalecer, em consequência do conceito da não-instrumentalização do ser humano, que jamais poderá ser considerado objeto de experiências e será sempre sujeito de seu destino e de suas escolhas, ${ }^{76}$ como expresso na Declaração de Helsinque, de 1964 e ainda em vigor: “Os interesses e o bem-estar do ser humano deverão prevalecer sobre o interesse exclusivo da sociedade ou da ciência" (tradução livre). ${ }^{77}$

\footnotetext{
${ }^{71}$ DALLARI, Sueli Gandolfi. A proteção do Direito à intimidade, a Confidencialidade e o Sigilo na Pesquisa em Saúde. In Benevides, Maria Victoria de Mesquita, Bercovici, Gilberto, Melo, Claudinei. Direitos Humanos , Democracia e República: Homenagem a Fábio Konder Comparato, cit., p. 904.

72 "Liberdade" e "Dignidade" da pessoa: dois paradigmas opostos ou complementares na bioética? In MARTINS-COSTA, Judith e MOLLER, Letícia Ludwig. Bioética e responsabilidade, cit., p. 75.

${ }^{73}$ Idem, p. 76.

${ }^{74} \mathrm{O}$ estado atual do biodireito, cit., p. 14.

${ }^{75}$ FERNANDÉZ, Javier Gavo, 10 palavras-chave em bioética. São Paulo: Paulinas, 2000, p. 25.

${ }^{76}$ MORAES, Maria Celina Bodin de. O princípio da dignidade humana. in Princípios do direito civil contemporâneo. Maria Celina Bodin de Moraes (coordenadora). Rio de Janeiro: Renovar, 2006, p. 33/34.

77 "Primacy of the human being. The interests and welfare of the human being shall prevail over the sole interest of society or science".
} 
O princípio da autonomia envolve também uma dimensão moral, de promoção da tolerância na sociedade plural, naquilo que implica o respeito aos valores do paciente. Como ressalta Heloisa Helena Barboza, o princípio da autonomia impõe o respeito às pessoas por suas opiniões e escolhas, segundo seus valores e crenças pessoais. $^{78}$

Pode-se dizer, então, que, em bioética, o princípio da autonomia significa o respeito à vontade do paciente, considerado capaz de se autogovernar, fazer suas opções e agir de acordo com elas, em seu próprio interesse.

Entretanto, considerar a capacidade de escolha da pessoa submetida a tratamento, pela consagração do princípio da autonomia na bioética, não significa, nem poderia ser diferente, a transferência integral da responsabilidade sobre a decisão quanto à melhor conduta para o cuidado da pessoa, do médico para o paciente. Em outras palavras, o fato de se atribuir relevo à vontade expressada pelo paciente não torna $\mathrm{o}$ médico um veículo mecânico e acrítico da realização do desejo alheio, devendo a autonomia, como todos os demais valores e princípios que compõem o sistema normativo, recuar diante dos limites postos pelo mesmo sistema.

José de Oliveira Ascenção, ao referir-se à autonomia do doente em relação ao próprio tratamento, prefere o termo autodeterminação, como algo que permita fixar o que queremos para nós mesmos. Lembra o autor português que nada é absoluto, sequer a autodeterminação do paciente em relação ao que pode determinar ao profissional, em relação à conduta médica. Em suas palavras: “Assim como nem tudo nos é permitido, também nem tudo pode ser determinado para que os outros façam". ${ }^{79}$

Do mesmo modo, pondera Roberto Andorno que a autonomia do paciente não deve ser entendida como uma imposição de desejos irracionais ao médico, já que a autonomia também se submete a critérios de razão. A avaliação racional, orientada por parâmetros objetivos, que transcendem os sujeitos em questão, evita o relativismo moral e traduz-se em esforço ético, evitando que o profissional da saúde se converta em agente a serviço do paciente, privado do sentido da arte de curar. Assim, afirma Roberto Andorno: "a autonomia não é o único nem o mais importante dos princípios bioéticos, senão que está subordinado a outros imperativos, sobretudo à busca do bem do paciente,

\footnotetext{
${ }^{78}$ BARBOZA, Heloisa Helena. Princípios do biodireito, in Novos Temas de Biodireito e bioética. Renovar, p. 55.

${ }_{79}$ A terminalidade da vida. In Martins-Costa Judith e Möller Letícia Ludwig. Bioética e Responsabilidade. Rio de Janeiro: Forense, 2009, p. 436.
} 
entendido este em sua significação mais ampla que inclui a exigência primordial de não lhe causar danos (primum non nocere)" ${ }^{80}$

No caso do transexual, assume-se a existência do desejo de realizar a cirurgia para a adaptação corporal ao gênero a que a pessoa se sente pertencer. Tal expressão de desejo, ainda que possa ser considerada como o exercício da autonomia individual, não é suficiente para que se proceda de imediato à transformação corporal, já que, como visto, a autonomia do paciente não tem o condão de subtrair a responsabilidade dos profissionais da saúde sobre a melhor forma de cuidado. Por isso, é necessário o acompanhamento da pessoa transexual por uma equipe multidisciplinar por prazos que variam de país para país, estabelecendo-se um processo preparatório, findo o qual a cirurgia poderá ou não ser indicada, sem necessariamente implicar o desrespeito à autonomia.

\section{a.1) O princípio da autonomia em pesquisa com seres}

\section{humanos}

O princípio da autonomia aplica-se também às pesquisas com seres humanos, colhendo-se a concordância do sujeito por meio da assinatura do termo de consentimento esclarecido.

Trata-se da hipótese da transformação corporal de uma mulher para um homem, cuja cirurgia se encontra em fase experimental no Brasil, nos termos da

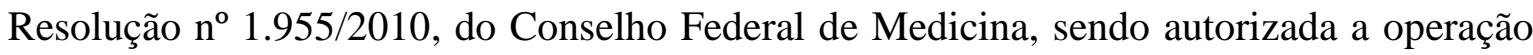
somente no âmbito da pesquisa. Por isso, exige-se a formalização da ciência e concordância da pessoa com o procedimento, por meio da assinatura do termo de consentimento informado.

O consentimento informado, na definição de Lydia Buisan Espeleta, consiste na "expressão máxima do princípio da autonomia constituindo um direito do paciente ou do sujeito da pesquisa e um dever do médico". ${ }^{81}$ A partir dessa definição, Heloísa Helena Barbosa entende que o princípio da autonomia, no âmbito da saúde, protege o paciente de tudo o que possa limitar ou reduzir sua autonomia, desde que

80 "Liberdade" e "Dignidade" da pessoa: dois paradigmas opostos ou complementares na bioética? In MARTINS-COSTA, Judith e MOLLER, Letícia Ludwig. Bioética e responsabilidade, cit., p. 78.

${ }^{81}$ Bioética y principios básicos de ética médica. In Materiales de Bioética y Derecho. Coord. María Casado. Barcelona: Cedecs Editorial S. L., 1996, p. 114/115. 
o sujeito tenha capacidade para compreender as informações sobre sua situação e as consequências de sua decisão, e de comunicar tal decisão de forma clara e reiterada. ${ }^{82}$

Diante da particularidade dos interesses envolvidos na área de pesquisa com seres humanos: o avanço científico, de um lado, e a saúde ou o corpo/mente do indivíduo, de outro, cumpre apontar diferença no sentido que se empresta ao princípio da autonomia na bioética, em contraposição àquele próprio dos negócios jurídicos patrimoniais. Como ensina Heloisa Helena Barboza: "O princípio da autonomia da vontade na relação pesquisador-sujeito de pesquisa transcende, e muito, a relação contratual" ${ }^{83}$

Sustenta a respeitada professora que as relações entre o pesquisador e o sujeito de pesquisa, em razão da particularidade de seu objeto, não devem ter natureza contratual, ainda que seja possível a existência de contrato para regular outras relações que não a pesquisa em si. Por isso, o consentimento deve ser interpretado à luz do princípio da dignidade humana, dos direitos fundamentais do homem e dos direitos da personalidade, aplicando-se apenas supletivamente as regras relativas à autonomia da vontade como aplicadas aos negócios jurídicos, concluindo: "Toda interpretação deve ser voltada para a proteção da pessoa humana, por definição vulnerável (quando já não vulnerada) no caso de pesquisa". ${ }^{84}$

Assim, o princípio da autonomia na bioética está ligado à capacidade de compreender o próprio estado de saúde e os riscos envolvidos, e de decidir e ser respeitado em sua decisão, dividindo com o profissional da saúde os rumos do tratamento, somente possível a participação em pesquisa, mediante a assinatura do termo de consentimento esclarecido.

\section{3.b) O princípio da beneficência}

O princípio da beneficência, por sua vez, dirige-se ao médico e ao profissional da saúde, estipulando que o tratamento só pode ser utilizado para o bem do enfermo, e nunca para fazer o mal ou praticar injustiça, segundo a capacidade e juízo do médico ${ }^{85}$ traduzindo-se na "obrigação de não causar dano e de extremar os benefícios e minimizar os riscos". ${ }^{86}$

\footnotetext{
${ }^{82}$ BARBOZA, Heloisa Helena. Responsabilidade Civil em Face de Pesquisas em Seres Humanos: Efeitos do Consentimento Livre e Esclarecido. In Martins-Costa Judith e Möller Letícia Ludwig. Bioética e Responsabilidade. Rio de Janeiro: Forense, 2009, p. 227.

${ }^{83}$ Idem, p. 228

${ }^{84}$ Idem, mesma página.

${ }^{85}$ DINIZ, Maria Helena. O estado atual do biodireito, cit., p. 14.

${ }^{86}$ BARBOZA, Heloisa Helena. Princípios do biodireito, in Novos Temas de Biodireito e bioética, cit., p. 55
} 


\section{3.c) O princípio da não-maleficência}

O princípio da não-maleficência é um desdobramento do da beneficência, "por conter a obrigação de não acarretar dano intencional" 87 ao paciente, inexistindo distinção significante entre um e outro princípio. ${ }^{88}$

\section{3.d) O princípio da justiça}

Por fim, o princípio da justiça representa a dimensão política e social da saúde da pessoa humana. ${ }^{89}$

Significa a imparcialidade na distribuição dos riscos e benefícios, não podendo uma pessoa ser tratada de modo diferente da outra, salvo haja uma diferença relevante entre elas. ${ }^{90}$

Trata da justiça distributiva, com o objetivo de tratamento igual aos iguais, no que tange à distribuição dos benefícios dos serviços de saúde. ${ }^{91}$

Possui, também, uma acepção comunicativa, por terceiros ou grupos de defesa da vida ou outro interesse, com influência na opinião pública, objetivando combater a discriminação. ${ }^{92}$

\section{3.e) Outros paradigmas para a reflexão bioética}

Uma das críticas dirigidas à dogmática dos princípios refere-se à falta de unidade sistemática da bioética principialista, já que cada princípio está calcado em uma matriz diferente da filosofia moral: o da beneficência, no utilitarismo de Stuart Mill; o da autonomia, na filosofia moral kantiana; e o princípio da justiça, no contratualismo, o que acabaria levando a uma aplicação mecânica e dogmática dos princípios. ${ }^{93}$

Nessa quadra, defende Vicente de Paulo Barretto, citando Monique Castillo, a necessidade de uma nova resposta ética aos desafios colocados pelo progresso científico e tecnológico, construída sobre duas, não excludentes, concepções de responsabilidade: "a responsabilidade do bem - que obriga a preservação - e a

\footnotetext{
${ }^{87}$ DINIZ, Maria Helena. O estado atual do biodireito, cit., p. 14.

${ }^{88}$ BARBOZA, Heloisa Helena. Princípios do biodireito, in Novos Temas de Biodireito e bioética, cit., p. 55.

${ }^{89}$ GAMA, Guilherme Calmon Nogueira da. A nova filiação: o biodireito e as relações parentais. Rio de Janeiro: Renovar, 2003, p. 67.

${ }^{90}$ Idem, mesma página.

${ }^{91}$ CORREIA, Francisco de Assis. Alguns desafios atuais da bioética. In Fundamentos da bioética. Pessini, Léo e Barchifontaine, Christian de Paul de (orgs), Paulus, p. 42.

${ }^{92}$ DINIZ, Maria Helena. O estado atual do biodireito, cit., p. 15.

93 BARRETTO, Vicente de Paulo. Bioética, Responsabilidade e Sociedade Técnocientífica". In MARTINSCOSTA, Judith e MOLLER, Letícia Ludwig. Bioética e responsabilidade. Editora Forense, p. 19
} 
responsabilidade do melhor - que determina o progresso ou o aperfeiçoamento qualitativo da vida humana". 94

De acordo com o citado autor, os princípios clássicos da bioética afiguram-se insuficientes para normatizar o progresso, considerando sua abstração e a impossibilidade de dogmatizar o comportamento de um agente moral. Diante disso, Vicente Barreto propõe uma concepção humanista da ética, resultante do embate entre a responsabilidade do bem e a responsabilidade do melhor, na tentativa de harmonizar o respeito à dignidade da pessoa humana com as aspirações de progresso, em benefício dessa mesma pessoa. Com base nas duas vertentes da responsabilidade, afirma o autor: "Dessa forma, teríamos uma ética que refletisse e fornecesse argumentos para preservar o ritmo do progresso científico e técnico, próprio da contemporaneidade, e o bem maior que reside na qualidade de vida da pessoa humana", concluindo: "O componente propriamente ético dessa cultura, que se constrói em torno da ciência, servirá, assim, não como limitador do progresso científico, mas como elemento humanizador". ${ }^{95}$

A par do paradigma principialista que institui a análise bioética com base nos princípios supra, identifica a doutrina outros modelos de análise teórica das questões bioéticas. São eles o paradigma libertário, o paradigma das virtudes, o paradigma casuístico, o paradigma fenomenológico e hermenêutico, o paradigma narrativo, o paradigma do cuidado, o paradigma do direito natural, o paradigma contratualista e o paradigma antropológico personalista, aprofundados por Leo Pessini e Christian de Paul de Barchifontaine, ${ }^{96}$ ora brevemente mencionados apenas a título de ilustração.

Segundo os autores, o paradigma libertário inspira-se na tradição filosófica do liberalismo norte-americano e é defendido por Tristam Engelhardt (The foundation of bioethics), baseado na defesa dos direitos e da propriedade dos indivíduos, assumindo o corpo como propriedade do paciente na venda de sangue e órgãos. ${ }^{97} \mathrm{O}$ paradigma das virtudes, reativamente, enfatiza o papel do agente da saúde, que deve fazer da virtude um hábito para a prática do bem, sendo defendido por Edmund Pellegrino e David Thomasma (For the patient's good). O paradigma casuístico, como o nome sugere, preconiza que a decisão para a ação deve ser tomada em cada caso, não se apoiando em princípios orientadores para a ação, mas, sim, em casos paradigmáticos formadores de uma

\footnotetext{
${ }^{94}$ Idem, mesma página.

95 Idem, mesma página.

${ }^{96}$ PESSINI, Leocir. BARCHIFONTAINE, Christian de Paul de. Problemas atuais de bioética. $9^{\text {a }}$ Ed. São Paulo: Centro Universitário São Camilo; Loyola, 2010, p. 46/49.

${ }^{97}$ Idem, p. 46.
} 
plataforma comum para comparações e contrastes, tratando-se do modelo defendido por Albert Jonsen e Stephen Toulmin, na obra The abuse of casuistry. O paradigma fenomenológico e hermenêutico pretende separar a dimensão subjetiva da interpretação, da dimensão objetiva da situação em si, a fim de clarear significados que possam ser analisados e partilhados, em fuga da superficialidade dos princípios abstratos para dirigir uma escolha moral. O paradigma narrativo, por sua vez, assume que toda situação confrontada pelo eticista possui uma dimensão narrativa, inseparável da vida, que deve ser considerada em complemento aos princípios formais; enquanto o paradigma do cuidado, desenvolvido por Carol Gilligan em In a different voice, propõe o cuidado como noção fundamental para o desenvolvimento moral. O paradigma do direito natural parte da existência de bens fundamentais em si mesmos (o conhecimento, a vida, a vida estética, a vida lúdica, a racionalidade prática, a religiosidade, a amizade), cuja validade moral é consensual. A partir dessa premissa, John Finnis entende como moral toda ação que contribuir para o desenvolvimento desses valores. O paradigma contratualista, de Robert Veatch, na obra $A$ theory of medical ethics, defende um triplo contato: entre o médico e o paciente; o médico e a sociedade; e entre os princípios da beneficência, da proibição de matar, de dizer a verdade e de manter as promessas, na relação médico-paciente. Por fim, o paradigma antropológico personalista, o mais abrangente no cenário europeu, parte de características que entende essenciais ao ser humano: unicidade da subjetividade individual, caráter relacional da intersubjetividade ("a pessoa é, por natureza e condição, um ser aberto aos outros e ao mundo"), ${ }^{98}$ e comunicação e solidariedade em sociedade, para desenvolver raciocínio de fundamentação teleológica, que considera o ser humano o valor supremo do agir.

Como anotam os autores Leo Pessini e Christian de Paul de Barchifontaine, os diversos paradigmas bioéticos são caminhos diferentes para uma plataforma comum, que pretendem ampliar as discussões éticas para fora do círculo dos princípios, "uma vez que a grandeza e a profundidade da experiência humana sempre estarão além de qualquer sistema filosófico ou teológico". 99

\footnotetext{
${ }^{98}$ PESSINI, Leocir. BARCHIFONTAINE, Christian de Paul de. Problemas atuais de bioética, cit., p. 49.

${ }^{99}$ Idem, mesma página.
} 


\section{4) O Princípio Responsabilidade de Hans Jonas e a}

transexualidade

\section{4.a) Os limites da ética fundada na simultaneidade entre a} ação e o resultado, no atual estado da técnica

O tema da responsabilidade foi objeto de aprofundamento por Hans Jonas, cujas lições são pertinentes de serem trazidas.

Constata Hans Jonas que a técnica moderna e a amplitude das possibilidades de intervenção humana na natureza introduziram ações de tal ordem de grandeza que a ética antiga, baseada na simultaneidade entre a ação e o resultado e limitada no espaço, não consegue lidar. Diante disso, aponta o autor a necessidade de impor à ética uma nova dimensão de responsabilidade: a natureza como responsabilidade humana. ${ }^{100}$

Essa nova ética, porque preocupada com a natureza como algo necessário à sobrevivência humana, mantém uma orientação antropocêntrica, mas com diferenças substanciais em comparação com a filosofia antiga. Tais diferenças remontam ao desaparecimento das limitações de proximidade e simultaneidade, à irreversibilidade e ao caráter cumulativo dos efeitos, que vão se somando, de modo a transformar o cenário de atuação dos próximos atores, ${ }^{101}$ formando um contexto substancialmente diverso daquele que inspirou os cultores da ética antiga.

O desenvolvimento da técnica, outrossim, em constante avanço, deixa clara nossa ignorância. Admitir essa ignorância torna-se o outro lado da obrigação do saber e passa a integrar a ética. Isso porque o reconhecimento do limite do saber resulta na consciência da ignorância quanto aos resultados da ação a longo prazo, consciência essa que deve instruir o autocontrole do homem sobre seu poder. Como assevera Hans Jonas: "Reconhecer a ignorância torna-se, então, o outro lado da obrigação do saber, e com isso torna-se uma parte da ética que deve instruir o autocontrole, cada vez mais necessário, sobre o nosso excessivo poder". ${ }^{102}$

A grandeza das ações proporcionadas pela técnica moderna introduz um novo problema ético. Assim, inserem-se na doutrina do agir considerações sobre a condição global da vida humana e o futuro distante, inclusive da espécie humana.

\footnotetext{
100 JONAS, Hans. O princípio responsabilidade: ensaio de uma ética para a civilização tecnológica. Tradução do original alemão Marijane Lisboa e Luiz Barros Montez. Rio de Janeiro: Contraponto: ED. PUCRio, 2006, p. 39.

${ }^{101}$ Idem, p. 40

102 Idem, p. 41.
} 
Nesse aspecto, a modificação de premissas básicas - limitação temporal e espacial entre ação e resultado - implica a impossibilidade de aplicar os conhecidos princípios da ética e da metafísica na tarefa de pensar os problemas atuais, procurando-se uma nova concepção de direitos e deveres. Nas palavras de Hans Jonas: "Nenhuma ética anterior vira-se obrigada a considerar a condição global da vida humana e o futuro distante, inclusive a existência da espécie. $\mathrm{O}$ fato de que hoje eles estejam em jogo exige, numa palavra, uma nova concepção de direitos e deveres, para a qual nenhuma ética e metafísica antigas podem sequer oferecer princípios, quanto mais uma doutrina acabada". ${ }^{103}$

Hans Jonas constrói sua concepção ética em contraposição à kantiana, trazida como paradigma da ética da simultaneidade. Para H. Jonas, o imperativo categórico "Aja de modo que tu também possas querer que tua máxima se torne lei geral" era voltado para o indivíduo, sugerindo uma avaliação atual sobre o que aconteceria se a ação individual fosse transformada em um princípio de legislação geral, como forma de colocar à prova a escolha privada. Nesse sentido, o autor sugere a necessidade de uma nova ética, que leve em consideração a preocupação com o futuro das gerações, reformulando o imperativo Kantiano: “Aja de modo a que os efeitos da tua ação sejam compatíveis com a permanência de uma autêntica vida humana sobre a Terra". ${ }^{104}$

Outro aspecto ressaltado por Hans Jonas, ao analisar o impacto da tecnologia sobre as ações humanas e concluir pela necessidade de uma nova ética, refere-se à inserção do próprio homem entre os objetos da técnica. $\mathrm{O}$ risco de tornar o homem objeto da técnica é apontado por Hans Jonas por meio da definição do homo faber: “o homem quer tomar em suas mãos a própria evolução, a fim não meramente de conservar a espécie em sua integridade, mas de melhorá-la e modificá-la segundo seu próprio projeto". 105

O autor exemplifica como obra do homo faber na era da técnica as conquistas da ciência frente à mortalidade, inovando em tema antes encarado como um fato natural diante do qual nada havia a ser feito. Nas palavras do autor, ao tratar do tema da morte: "A questão era apenas a de como se comportar diante do que era dado". ${ }^{106}$ Tal realidade, modificada no que toca à relação do homem com o fim da vida, traz novas questões éticas, como na indagação do autor, a necessidade de escolha entre o

\footnotetext{
${ }^{103}$ Idem, mesma página.

${ }^{104}$ Idem, p. 47.

${ }^{105}$ Idem, p. 61.

${ }^{106}$ JONAS, Hans. O princípio responsabilidade, cit., p. 58.
} 
prolongamento da vida dos mais velhos e a abertura do mundo para a ocupação dos não nascidos.

Após constatar a insuficiência da ética baseada na simultaneidade entre a ação e o resultado para fornecer critérios de solução às questões resultantes do avanço tecnológico, Hans Jonas reafirma a necessidade de preenchimento do vazio, convencido de que uma ética tem de existir: "Ela tem de existir porque os homens agem, e a ética existe para ordenar suas ações e regular seu poder de agir", ${ }^{107}(\ldots)$ "indicando-nos como uma estrela-guia aquilo que é o bem ou o permitido". 108

\section{4.b) Os contornos do Princípio Responsabilidade proposto}

por Hans Jonas

Após o aprofundamento dos conflitos atuais, Hans Jonas encontra no Princípio Responsabilidade uma alternativa ética para fazer frente às novas questões colocadas pelo desenvolvimento científico e tecnológico.

Segundo o autor, o fenômeno original de responsabilidade encontra traços comuns na responsabilidade pessoal e íntima que se verifica entre pais e filhos e na responsabilidade do homem público ou legislador sobre os indivíduos numerosos e anônimos da sociedade, ignorados na própria identidade. Tais traços comuns podem ser resumidos em três conceitos: totalidade, continuidade e futuro. ${ }^{109}$

De acordo com suas lições, há uma afinidade entre sujeito e objeto na relação de responsabilidade, baseada no arquétipo de toda responsabilidade, que é aquela do homem pelo homem, simbolizada pelos cuidados parentais. Nas palavras de $\mathrm{H}$. Jonas, "Nesse paradigma arquetípico evidencia-se de forma cristalina a ligação da responsabilidade com o Ser vivo. Somente o Ser vivo, em sua natureza carente e sujeita a riscos - e por isso, em princípio, todos os seres vivos - , pode ser objeto de responsabilidade". ${ }^{110}$

A primeira responsabilidade é garantir a possibilidade de que haja responsabilidade, pela garantia da existência do homem. ${ }^{111}$ Ou seja, sem o homem não haveria o sujeito da responsabilidade, pelo que se explica a afirmação de que a primeira

\footnotetext{
${ }^{107}$ Idem, p. 65.

${ }^{108}$ Idem, p. 66.

${ }^{109}$ Idem, p. 174/175.

${ }^{110}$ Idem, p. 175.

${ }^{111}$ JONAS, Hans. O princípio responsabilidade, cit., p. 177.
} 
responsabilidade é a de garantir a continuação da existência humana, concluindo que a responsabilidade se refere sobretudo à vida humana. ${ }^{112}$

A característica da totalidade significa que a responsabilidade abarca o Ser total do objeto, desde sua existência bruta até seus interesses mais elevados. Preocupa-se não só com a sobrevivência do Ser, mas também com a qualidade de sua vida. $^{113}$

A característica da continuidade significa que o exercício da responsabilidade não pode ser interrompido, procedendo-se de modo histórico, a fim de garantir uma continuidade do objeto em sua historicidade : "na questão da continuidade através do tempo há uma identidade a ser garantida, que integra a responsabilidade coletiva". 114

Derradeiro traço característico da responsabilidade é aquele que se ocupa prioritariamente com o futuro, mais do que com o presente imediato. $\mathrm{O}$ conceito de responsabilidade pelo futuro impõe a renúncia atual em prol do direito daquele que ainda não existe e cujo futuro a responsabilidade objetiva garantir. Nesse sentido, "a responsabilidade não é nada mais do que o complemento moral para a constituição ontológica do nosso Ser temporal". 115

\section{4.c) A bioética e o Princípio Responsabilidade}

O Princípio Responsabilidade faz-se presente na reflexão

bioética.

A bioética pode ser entendida como indagação filosófica sobre os limites da intervenção humana na natureza, operando como restrição a tudo aquilo que a ciência e a tecnologia possibilitam e cada vez mais possibilitarão, em nome do princípio da dignidade.

Percebe-se, destarte, que a preocupação com a manutenção das condições necessárias à existência atemporal, contínua e de qualidade do ser humano na terra, ainda que às custas da imposição de limites ao desenvolvimento científico, é comum e encontra-se no Princípio Responsabilidade e na bioética, que ganham relevância no mundo moderno marcado por um novo tipo de risco.

\footnotetext{
112 Idem, p. 179.

113 Idem, p. 180.

${ }^{114}$ Idem, p. 186.

115 Idem, p. 187.
} 
Além do risco criado pela natureza, admite-se um risco fabricado, decorrente do impacto do conhecimento e do progresso científico e tecnológico. A existência do risco sempre foi inerente à sociedade, mas a imponderabilidade dos resultados em consequência do desenvolvimento da técnica tornou mais difícil o equilíbrio entre os benefícios e os perigos advindos do progresso. ${ }^{116}$ Daí a importância do oferecimento de parâmetros para a orientação do desenvolvimento científico, na tentativa de administrar o risco e proteger a existência da humanidade, em atenção à primeira responsabilidade identificada por Hans Jonas: garantir a possibilidade de que haja responsabilidade, pela garantia da existência do homem. ${ }^{117}$

Assim, constata-se que o Princípio Responsabilidade na reflexão bioética se faz notar na atenção ao risco inerente ao avanço tecnológico e na preocupação com o futuro da humanidade.

O desenvolvimento da técnica, outrossim, abriu possibilidades de intervenção no próprio homem, tornando possível o que antes era impensado, como a transformação de um órgão sexual externo masculino em feminino, para citar um exemplo. Diante disso, abre-se outra perspectiva de risco inerente à inclusão do homem entre os objetos da técnica: a reificação do ser humano, assim entendida a "transformação experimentada pela atividade produtiva, pelas relações sociais e pela própria subjetividade humana, sujeitadas e identificadas cada vez mais ao caráter inanimado, quantitativo e automático dos objetos ou mercadorias circulantes no mercado", ${ }^{118}$ que resultaria do tratamento da pessoa como coisa, em violação à sua dignidade.

A reificação do corpo é assim entendida como risco indesejável, representativa de perigo, como aponta a doutrina colacionada por Guilherme Calmon Nogueira da Gama. ${ }^{119}$

À tentativa de controle desse risco, socorrem os princípios da responsabilidade e da dignidade humana, vetor máximo de orientação da reflexão bioética, que em sua essência repudia qualquer conotação do ser humano como coisa. Reconhece a doutrina que, embora exista uma dificuldade de determinar o conteúdo material dos valores intrínsecos à dignidade, seu fundamento reside na concepção de que a subjetividade

\footnotetext{
${ }^{116}$ BARBOZA, Heloisa Helena. Responsabilidade Civil em Face de Pesquisas em Seres Humanos: Efeitos do Consentimento Livre e Esclarecido, cit., p. 211/212.

117 JONAS, Hans. O princípio responsabilidade, cit., p. 177.

118 Dicionário Houaiss da Língua Portuguesa.

${ }^{119}$ A nova filiação: o biodireito e as relações parentais: o estabelecimento da parentalidade-filiação e os efeitos jurídicos da reprodução assistida heteróloga. Rio de Janeiro: Renovar, 2003, p. 16 e nota de rodapé $\mathrm{n}^{\mathrm{o}} 11$.
} 
humana não pode ser reificada, presente na consciência coletiva, ${ }^{120}$ afastando-se a possibilidade de disposição do indivíduo como se coisa fosse.

Nessa quadra, o paradigma do valor supremo da pessoa humana, de sua vida, dignidade, liberdade e autonomia, comum à bioética e ao princípio responsabilidade, implica a averiguação da legitimidade do uso de novas tecnologias para transformar a qualidade de vida das pessoas, sem reduzir a espécie humana, como alerta Rifkin, a um produto tecnologicamente projetado. ${ }^{121}$

No que diz respeito ao tema da transexualidade sob o enfoque da bioética, as lições de Hans Jonas provocam reflexões sobre o direito ao próprio corpo e os limites de sua transformação, a partir do pressuposto de que a possibilidade técnica, por si só, é insuficiente para legitimar a ação humana sobre a natureza, em atenção ao princípio responsabilidade e suas notas de totalidade, continuidade e futuro.

Essa perspectiva ética da responsabilidade, que é complementar mas não se confunde com a dignidade, não pode ser perdida de vista no enfrentamento do tema, considerando que uma das soluções pensadas para a situação dos transexuais é a construção de um novo órgão sexual, por meio da intervenção cirúrgica.

Tal cirurgia representa delicada intervenção na natureza, tornada possível pelo avanço da técnica. Mas suas consequências podem não ser confortáveis do ponto de vista físico e funcional, visto que importam na transformação de um corpo saudável em um corpo que passará a requerer constantes acompanhamentos e cuidados, além da ingestão de hormônios. Nesse sentido, o traço da totalidade, próprio do princípio responsabilidade, deve orientar a decisão quanto à conveniência da cirurgia, reafirmando a preocupação em tornar boa a vida do Ser, de forma durável (continuidade) e sem riscos para o futuro da espécie humana.

Ou seja, a defesa da dignidade que se pretende alcançar por meio do tratamento cirúrgico-hormonal não prescinde da avaliação da situação também sob o enfoque do princípio responsabilidade, somente convindo a modificação substancial da natureza em hipóteses em que se possam obter resultados efetivamente satisfatórios para o Ser, em sua totalidade.

Essa assertiva não significa deixar a pessoa transexual desamparada ou sem alternativa, nem tampouco dificultar sua inclusão social. Apenas que

\footnotetext{
${ }^{120}$ D'AGOSTINO, Francesco. A dignidade, princípio bioético. Bioética segundo o enfoque da filosofia do direito. Título original: Bioetica nella prospettiva della filosofia del diritto, cit., p. 78.

${ }^{121}$ DINIZ, Maria Helena. O estado atual do biodireito, cit., p. 13.
} 
a defesa da pessoa em sua totalidade implica uma reflexão interdisciplinar, sobre as consequências da cirurgia para a saúde e sobre o papel do Direito na normatização do estado civil, de modo a criar alternativas para aquele que sofre de transtorno de identidade de gênero, independentemente da intervenção cirúrgica.

Pelo exposto, pode-se concluir que o avanço tecnológico e científico responsivos ao desejo onipotente do ser humano pode não encontrar freios em si mesmo, tornando necessário não perder de vista o princípio da dignidade, os demais princípios da bioética e o princípio responsabilidade, como vetores de orientação para a tomada de decisão e a avaliação de condutas.

\section{4.d) Perspectiva crítica: a utilização da técnica como meio de}

\section{controle social, segundo Hans Jonas}

A cirurgia transformadora do sexo anatômico de um homem em órgão feminino, e vice-versa, é tema que inspira indagações no campo da bioética, como já afirmado. Agora, cumpre analisar a questão pelo ângulo da utilização das técnicas da medicina e da biologia como meio de controle social, tratando-se de outra abordagem ética.

Lembra o autor alemão que, além de aliviar o paciente, os remédios e tratamentos muitas vezes aliviam a sociedade. Isso porque os sintomas da patologia podem ser sentidos como inconvenientes sociais, decorrentes de comportamentos individuais difíceis, que os tratamentos e remédios ajudariam a neutralizar. Dessa forma, o avanço da técnica sobre o homem teria não só uma aplicação médica, mas também uma aplicação social, de neutralização da diferença naquilo que parecesse inconveniente para a sociedade de massa.

Essa função social e não medicinal da técnica, aponta Hans Jonas, traz questões éticas inquietantes relativas à manipulação do homem, transcendentais à medicina, porque referidas à finalidade diversa, voltada à intervenção na natureza humana com propósitos sociais.

$\mathrm{Na}$ exata lição do autor: "Libertar doentes mentais de sintomas dolorosos e perturbadores parece ser algo claramente benfazejo. Mas uma discreta transição leva do alívio do paciente - um objetivo em total consonância com a tradição médica - a aliviar a sociedade da inconveniência de comportamentos individuais difíceis entre seus membros. Isso significa a transição da aplicação médica para o social e abre um campo indefinível, que contém potencialidades inquietantes. Os renitentes problemas da 
ordem e da anomia na moderna sociedade de massas tornam extremamente sedutora, para os fins de manipulação social, a aplicação desses métodos de controle de forma nãomedicinal". ${ }^{122}$

A utilização da técnica com a função social de neutralizar a diferença contraria o propósito de desenvolver a tolerância, inspirador da sociedade democrática. De fato, o apaziguamento social passível de ser obtido por meio da medicalização do diferente subtrai a possibilidade de promoção do respeito e do reconhecimento social dessa mesma diferença. Nessa medida, atenta contra a dignidade da pessoa, ao sujeitá-la à satisfação das expectativas de padronização, suprimindo-lhe a individualidade e autonomia próprias e essenciais do Ser.

Como aponta Hans Jonas, ao tratar do uso da técnica com finalidade social: "sempre que contornamos dessa maneira o caminho humano para enfrentar os problemas humanos, substituindo-o pelo curto-circuito de um mecanismo impessoal, subtraímos algo da dignidade dos indivíduos e damos mais um passo à frente no caminho que nos conduz de sujeitos responsáveis a sistemas programados de conduta". ${ }^{123}$

Tomado o exemplo do transexual, a situação poderia ser posta da seguinte maneira: o conflito do Ser é um dado, vislumbrado pelo descompasso entre o sexo biológico da pessoa e o gênero ao qual se sente e deseja pertencer, o que colide com a expectativa de aceitação do papel social e, nessa medida, é fonte de desconforto individual e social.

A partir daí, o avanço da técnica passou a permitir o tratamento cirúrgico e hormonal para transformar a pessoa, ao menos externamente, no sexo desejado. Realizada a cirurgia, deixa a pessoa de ser o que era, adaptando-se àquilo previamente conhecido e socialmente reconhecido, o que pode resultar na supressão de sua individualidade e dignidade, na hipótese em que a autorização para a cirurgia estivesse mais voltada ao controle e apaziguamento social do que ao bem da pessoa.

Para que tal não ocorra, releva não perder de vista a realidade do transexual, em sua singularidade e autonomia, buscando-se alternativas de tutela jurídica inclusive para aqueles que não desejem se submeter à operação, a fim de que o tratamento cirúrgico seja sempre orientado pela perspectiva de cuidado com a saúde e respeito ao corpo da pessoa, e não pela finalidade social de que trata Hans Jonas.

\footnotetext{
${ }^{122}$ JONAS, Hans. O princípio responsabilidade, cit., p. 60.

${ }^{123}$ Idem, mesma página.
} 
Somente assim haverá efetivamente uma contribuição para a proteção da dignidade dos transexuais, em respeito à sua diferença.

\section{5) A bioética e o biodireito}

A ciência promove mudanças na realidade, trazendo novas questões que exigem solução jurídica para a regulação de fatos e conflitos não previsíveis na época em que as leis foram elaboradas.

Nas palavras de Francesco D’agostino, professor de filosofia do direito e teoria geral na Universidade de Roma: "Em seu horizonte paradigmático tradicional, o direito gere ao mesmo tempo a natureza e o artifício; mas os problemas da bioética nascem justamente quando se manifesta a percepção social de que a dimensão da naturalidade tornou-se evanescente e que foi ultrapassado o umbral de suportabilidade da artificialização da vida". ${ }^{24}$

Pode-se daí extrair, ao que parece, a capacidade do direito para lidar tanto com eventos da natureza, quanto com fatos artificiais, dentro de certos limites, fixando nas questões bioéticas as situações de dificuldade de resposta jurídica para o problema posto, considerando a perplexidade social à vista dos resultados da técnica.

A transexualidade situa-se nessa fronteira, como exemplifica Maria Helena Diniz ao ilustrar as questões bioéticas da atualidade. ${ }^{125}$

$\mathrm{Na}$ avaliação da autora, diante dos desafios postos pela medicina, surge o biodireito como uma nova disciplina que toma por fontes diretas a bioética e a biogenética, tendo a vida por objeto principal, na consideração de que a verdade científica não pode se sobrepor à ética ou ao direito. ${ }^{126}$

De fato, as conclusões da reflexão bioética, aprofundadas pelos profissionais da saúde por ocasião das pesquisas, não substituem o estudo dos mesmos temas pelos juristas, uma vez que a fixação das consequências jurídicas das novas realidades tornadas possíveis pela ciência incumbe exclusivamente ao direito, único instrumento regulador do "momento do início e do fim da produção de efeitos jurídicos de cada fenômeno". ${ }^{127}$

\footnotetext{
${ }^{124}$ A bioética como problema jurídico. in Bioética segundo o enfoque da filosofia do direito. Título original: Bioetica nella prospettiva della filosofia del diritto, cit., p. 99.

${ }^{125} \mathrm{O}$ estado atual do biodireito, cit., p. 10.

${ }^{126}$ Idem, p. 07/08.

${ }^{127}$ BARBOZA, Heloisa Helena. Princípios do Biodireito. In Novos temas de biodireito e bioética, cit., p. 79.
} 
Nesse sentido, entende Guilherme Calmon Nogueira da Gama que a distinção entre a bioética e o biodireito corresponde à tradicional distinção entre a moral e o direito, ${ }^{128}$ apontando a necessária complementaridade entre os princípios éticos e as normas jurídicas à luz dos novos temas relacionados à vida.

Para o autor, diante da necessidade de formulação de regras em temas ligados à bioética, os Poderes do Estado são pressionados a editar novas normas, na tentativa de preenchimento do vazio jurídico, propiciando o desenvolvimento de um novo campo do conhecimento, denominado biodireito, ${ }^{129}$ resultante da "juridicização de determinados aspectos de temas bioéticos em virtude dos desdobramentos que a existência de um vazio normativo poderia causar a respeito de certas questões nos conflitos intersubjetivos de interesses". 130

O biodireito corresponderia, assim, às soluções jurídicas para as novas questões que se tornaram reais em consequência do avanço da técnica.

Decorre da extensão da bioética ao campo jurídico, ${ }^{131}$ e pode ser definido como a disciplina dedicada a estudar os fatos bioéticos pelo ângulo do direito, por meio da doutrina, legislação e jurisprudência, para regulamentar a conduta humana diante dos avanços da biotecnologia e da biomedicina. ${ }^{132}$

Exemplo de positivação de regras pelo biodireito, citado por Guilherme Calmon Nogueira da Gama, é a Declaração Universal do Genoma Humano e dos Direitos Humanos, de 1997, da Unesco, criadora de limites e de deveres ao direito interno dos países signatários quanto aos temas tratados, na tentativa de criar uma ordem ético-jurídica intermediária entre a bioética e o biodireito. ${ }^{133}$

Como a ciência está em constante desenvolvimento, possível imaginar que o mesmo ocorra com o biodireito, em sua corporificação e afirmação. Na citação de Heloisa Helena Barboza: "a imposição dos fatos faz com que o Biodireito, pouco a pouco se afirme, reunindo doutrina, legislação e a jurisprudência próprias,

\footnotetext{
${ }^{128} \mathbf{O}$ biodireito e as relações parentais, cit., p. 41 .

${ }^{129}$ Idem, p.37.

${ }^{130}$ Idem, p.53.

${ }^{131}$ BARBOZA, Heloisa Helena. Direito ao corpo e doação de gametas. In Rios, André Rangel (org) Bioética no Brasil. Espaço e Tempo, p. 42.

132 BARBOZA, Heloisa Helena. Responsabilidade Civil em Face de Pesquisas em Seres Humanos: Efeitos do Consentimento Livre e Esclarecido. In Martins-Costa Judith e Möller Letícia Ludwig. Bioética e Responsabilidade, cit., nota de rodapé n. 52, p. 227.

${ }^{133} \mathbf{O}$ biodireito e as relações parentais, cit., p. 110 .
} 
regulando, enfim, a conduta humana em face dos avanços da biotecnologia e da biomedicina". 134

Concorrem para a formação do biodireito as mesmas fontes normativas do direito em geral: princípios, regras, doutrina e jurisprudência.

Os princípios, na lição do professor Celso Lafer, promovem a expansão axiológica do direito, propiciando uma interpretação extensiva no campo dos direitos humanos. ${ }^{135}$

Em relação à doutrina, seu papel de fonte normativa é apontado por Orlando Gomes, que lhe reconhece suma importância, pois "São os doutrinadores que constroem as noções gerais, os conceitos, as classificações, as teorias, os sistemas, contribuindo para a criação, reforma e aplicação do Direito". ${ }^{136}$ Ao tratar da jurisprudência como fonte normativa, Caio Mario da Silva Pereira, após reconhecer que a função do Poder Judiciário não é formular regras, mas aplicá-las, atribui ao julgador um papel atualizador da lei, adaptando-a às transformações sociais e econômicas, concluindo: "Nesse sentido, é irrecusável que jurisprudência atua como força científica, induzindo até o legislador a elaborar novas normas de disciplina e de solução de problemas que repercutem no pretório antes de nas assembléias legislativas". ${ }^{137}$

No que toca aos costumes, tradicional fonte do direito, talvez não tenham larga aplicação no biodireito, pelo menos por enquanto, já que o objeto de regulação jurídica é novo. De fato, os costumes são cristalizados pela reiteração de condutas no tempo, criando expectativas da repetição de determinados padrões de ação. Também podem ser denominados como standards, ou formas de comportamento social típico, com caráter normativo integrado na consciência daqueles que atuam ou julgam determinada comunidade, identificados com a moral social dominante, referida na fórmula "bons costumes". 138

Pela sua própria essência, o costume pressupõe a prévia existência dos fatos sociais por algum tempo, para que diante deles se repitam

\footnotetext{
${ }^{134}$ BARBOZA, Heloisa Helena. Princípios do Biodireito. In Novos temas de biodireito e bioética, cit., p. $57 / 58$.

${ }^{135}$ Prefácio ao livro Ativismo Judicial: parâmetros dogmáticos. RAMOS, Elival da Silva. São Paulo: Saraiva, 2010, p. 14.

${ }^{136}$ GOMES, Orlando. Introdução ao Direito Civil. $19^{\mathrm{a}}$ ed. Revista e atualizada por Edvaldo Brito e Reginalda Paranhos de Brito. Rio de Janeiro: Forense, 2008, p. 44.

${ }^{137}$ Instituições de Direito Civil, vol I. $20^{\mathrm{a}}$ ed. Revista e atualizada por Maria Celina Bodin de Moraes. Rio de Janeiro: Forense, 2004, p. 58/59.

${ }^{138}$ LARENZ, Karl. Metodologia da Ciência do Direito. $3^{\text {a }}$ ed. Tradução José Lamego. Lisboa: Fundação Calouste Gulbenkian, 1997, p. 660.
} 
determinados padrões de comportamento, cuja força normativa decorre da expectativa de repetição.

Assim, no biodireito, a novidade dos temas implica que se aguarde certo período para a formação de costumes.

$\mathrm{O}$ biodireito constitui um microssistema orientado por princípios próprios, que devem se integrar aos demais princípios e normas do ordenamento vigente. ${ }^{139}$ Assim, as soluções jurídicas das difíceis questões devem ser buscadas principalmente nos valores que pautam a sociedade, importando mais as referências coletivas do que a consciência pessoal de cada um para a definição jurídica do fato social.

Nessa quadra, aponta Nogueira da Gama a inviabilidade de tornar o biodireito uma representação de particular concepção de vida ou moralidade específica, ${ }^{140}$ para o que socorrem os princípios constitucionais, expressões democráticas dos valores dominantes.

Mesmo assim, tratando-se de questões relativas à vida, à morte, à mudança de sexo, entre outras, subsistem pontos em que não há consenso. Nessa hipótese, defende Nogueira da Gama que “a normatização jurídica deverá buscar atender todos os valores morais e anseios das diversas comunidades", ${ }^{141}$ para o que propõem Maria de Fátima F. de Sá e Bruno T. de Oliveira Naves a necessidade de promover discussões sobre os polêmicos temas do biodireito, a fim de alcançar soluções legítimas. ${ }^{142}$

Sob esse aspecto, releva anotar a importância das audiências públicas previstas nas leis regulamentadoras da Ação Direta de Inconstitucionalidade e Declaratória de Constitucionalidade e da Arguição de Descumprimento de Preceito Fundamental (art. $9^{\circ}, \S 1^{\circ}$, da Lei $n^{\circ} 9.869 / 1999$ e art. $6^{\circ}, \S 1^{\circ}$, da Lei $n^{\circ} 9.882 / 99$ ), que preveem a possibilidade de participação pública no controle de constitucionalidade, a critério do relator. A audiência pública, nessa medida, realiza a dialética pluralista e a interdisciplinariedade próprias da bioética, no biodireito. ${ }^{143}$

Cotidianamente, contudo, não havendo audiência pública, são os princípios que auxiliam no desate das difíceis questões envolvendo a bioética.

\footnotetext{
${ }^{139}$ BARBOZA, Heloisa Helena. Princípios do Biodireito. In Novos temas de biodireito e bioética, cit., p. 50.

${ }^{140}$ GAMA, Guilherme Calmon Nogueira da. O biodireito e as relações parentais, cit., p. 57.

${ }^{141}$ Idem, mesma página.

${ }^{142}$ Da bioética ao biodireito. in Manual de Biodireito. Belo Horizonte: Del Rey, 2009, p. 18.

143 BORBA, Marina de Neiva. Bioética e Direito: Biodireito? Dissertação de mestrado em bioética apresentada no Centro Universitário São Camilo, 2010, p. 61.
} 
Na lição de Heloisa Helena Barboza, "a questão de fundo do Biodireito assenta, necessariamente, nos valores eleitos pelo sistema jurídico vigente, nos princípios gerais que traçam sua base estrutural". ${ }^{144}$ Tais valores consistem nos princípios constitucionais e não se confundem com os princípios gerais do Direito mencionados no art. $4^{\circ}$, da Lei de Introdução ao Código Civil Brasileiro, estes últimos "extraídos implicitamente da legislação pelo método indutivo", e somente utilizados em caso de omissão e insuficiência dos recursos à analogia e aos costumes. ${ }^{145}$

Os princípios constitucionais orientadores do biodireito, diversamente, correspondem àqueles positivados pela Constituição, como a vida, a dignidade humana, a liberdade e a solidariedade, que se tornaram pedras angulares da bioética moderna. ${ }^{146}$

Entre os princípios gerais do biodireito, Guilherme Calmon Nogueira da Gama ainda acrescenta o princípio da igualdade em sentido material, respeitando a singularidade e a diversidade de cada pessoa; o princípio da justiça social, ao lado do solidarismo; o princípio do pluralismo, que admite diversas convicções de valores morais e culturais; e o princípio da democracia, assegurador da cidadania. ${ }^{147}$

O autor identifica ainda princípios especiais do biodireito, como o princípio da disposição de partes do corpo humano, ainda que não de forma absoluta; o princípio da paternidade responsável; e o tema do direito à saúde, entendido pela OMS Organização Mundial da Saúde - como um estado de completo bem-estar físico, mental e social, e não apenas como ausência de doença. ${ }^{148}$

O biodireito, destarte, não resulta da mera transposição da bioética para o direito nem consiste em um sistema à parte, orientando-se por princípios próprios do ordenamento jurídico, cujo macrossistema prevalece em sua unidade e completude, a par do diálogo multidisciplinar.

Nesse sentido, vale transcrever trecho lapidar de Heloisa Helena Barbosa, ao tratar da interface entre o biodireito e a bioética: "Como indicado, tem a bioética princípios que lhe são próprios, mas a análise e regulamentação jurídicas dos

\footnotetext{
${ }^{144}$ Princípios do Biodireito. In Novos temas de biodireito e bioética, cit., p. 61.

${ }^{145}$ Tepedino, Gustavo. Temas de Direito Civil. $4^{\mathrm{a}}$ ed. Rio de Janeiro: Renovar, 2008, p. 18.

${ }^{146}$ BARBOZA, Heloisa Helena. Princípios do Biodireito, cit., p. 73.

${ }^{147}$ GAMA, Guilherme Calmon Nogueira da. O biodireito e as relações parentais, cit., p.119/122.

${ }^{148}$ Idem, p.123/125.
} 
problemas bioéticos, insista-se, deverão observar outra ordem de valores, outro método e diversa formulação, pertinentes ao direito". ${ }^{149}$

Pelo exposto, pode-se afirmar que a nomenclatura "biodireito" corresponde à regulação jurídica, pelo direito, das novas realidades materiais tornadas possíveis pelo desenvolvimento da técnica. Consiste, destarte, no cumprimento do papel do direito como instrumento regulador da conduta humana frente às novas questões, objetivando oferecer resposta aos conflitos de interesses e valores, em prol da harmonização social.

Para tanto, necessário debruçar-se, ainda que indiretamente e não com o aprofundamento próprio dos estudiosos das áreas da saúde, sobre o resultado científico que se problematiza em fato social não previsto, nos limites necessários a embasar uma reflexão no âmbito do direito. Tal estudo faz-se relevante para que a resposta jurídica tenha caráter de regulação efetiva e concreta e não de mera proposição teórica e distante da realidade, o que apenas enfraqueceria o direito por conta de sua provável ineficácia.

Com base nessa premissa teórica é que se propõe a analisar a transexualidade, a fim de encontrar alternativas para o enquadramento jurídico das questões suscitadas pelos transexuais, relativas à identidade, individualidade, aos direitos da personalidade e à tutela da dignidade.

\section{6) Nomenclatura:}

\section{6.a) transexualidade ou transexualimo?}

Este trabalho adotará, em regra, a nomenclatura transexualidade, no lugar de transexualismo, objetivando evitar a conotação de doença atribuída pelo sufixo "ismo".

Em que pese a manutenção do transexualismo na Classificação Internacional das Doenças em vigor, $10^{\mathrm{a}}$ versão, CID 10, sob o código F64, a abordagem do tema pela perspectiva dos direitos humanos implica uma maior flexibilidade na avaliação das formas individuais de expressão, a fim de não limitar o estudo à rigidez de um diagnóstico médico, que embace o olhar sobre a realidade da pessoa.

Não se exclui, outrossim, que o transexualimo venha a ser retirado da Classificação Internacional de Doenças, como aconteceu com a

${ }^{149}$ BARBOZA, Heloisa Helena. Princípios do Biodireito. In Novos temas de biodireito e bioética, cit., p. 74. 
homossexualidade, originalmente homossexualismo e hoje excluída do rol de doenças da mesma Classificação, valendo anotar que tal já ocorreu na França, primeiro país a promover a exclusão da transexualidade de sua lista nacional de doenças, em 2010.

Na reflexão de Pierre-Henri Castel, "Desde o momento em que a disforia de gênero não tem de médico senão o fato contingente de ser repertoriada entre as síndromes psiquiátricas, não existe mais razão em conservá-la que conservar a homossexualidade entre as doenças mentais", ${ }^{150}$ lembrando o autor que a homossexualidade foi retirada da lista de patologias em 1973.

Nesse contexto, optou-se pelo uso da palavra transexualidade, em geral, em substituição ao termo transexualismo, somente utilizado nas referências específicas a trabalhos que adotaram essa nomenclatura.

\section{6.b) O que se entende por transexual masculino e feminino}

A transexualidade caracteriza-se por uma contradição entre a identidade sexual ou de gênero com o sexo biológico, o que suscita uma dificuldade terminológica.

Neste trabalho, será adotada a nomenclatura utilizada por Yolanda B. Bustos Moreno, que privilegia o sexo de identificação.

Assim, será considerada "mulher transexual" o indivíduo que nasce com anatomia masculina e se identifica com o gênero feminino, e como "homem transexual" a pessoa que nasce com anatomia feminina, identificando-se com o sexo masculino. $^{151}$

\section{7) Transexualidade: conceito e distinções. Transexual} primário e secundário

A literatura médica especializada é farta na descrição da transexualidade, cujas lições acabaram assimiladas por aqueles que se debruçaram sobre o tema na área do direito.

Foram trazidas algumas dessas definições e referências, mais com o propósito de entender o sofrimento da pessoa transexual do que de esgotar os

\footnotetext{
${ }^{150}$ Algumas reflexões para estabelecer a cronologia do "fenômeno transexual" (1910-1995). Revista Brasileira de História. Vol. 21. no. 41. São Paulo: 2001. Disponível em: http://dx.doi.org/10.1590/S010201882001000200005, último acesso em 03/01/2012.

${ }_{151}$ MORENO, Yolanda B. Bustos. La Transexualidad (De acuerdo a la Ley 3/2007, de 15 de marzo). Madri: Dykinson, 2008, p. 27.
} 
critérios de diagnóstico da transexualidade, no pressuposto de que a contribuição acadêmica, se possível, não se dará na área da saúde.

Optou-se por limitar o estudo sobre as definições da transexualidade àquilo que pareceu suficiente para compreender os mecanismos envolvidos, sem a preocupação de esgotar todos os autores, de modo a manter o foco nos direitos humanos daqueles que vêm sendo reiteradamente discriminados e violentados pela sociedade, sempre com vistas a encontrar a melhor forma para a tutela de sua dignidade.

A existência de pessoas transexuais, inconformadas com o sexo biológico e convictas de pertencer ao sexo oposto, não é novidade. O que mudou foi a possibilidade de realização do desejo de mudança de sexo, tornado possível pelo avanço da medicina e da técnica cirúrgica.

Segundo Alexandre Saadeh, doutor sobre a transexualidade pelo Instituto de Psiquiatria do Hospital das Clínicas da USP, em junho de 2004, "Pessoas inconformadas com seu gênero de origem - seu sexo anatômico - sempre existiram na história humana. Mas foi a partir do século 20 que esses indivíduos puderam ser vistos pela moral e pela polícia". ${ }^{152}$

Na literatura, encontra-se a descrição do fenômeno desde o século XIX, nos relatos dos sexólogos Havelock Ellis e sobretudo Krafft-Ebing, embora, na época, não se usasse a nomenclatura transexuais, mas, sim, a indicação de delírios de metamorfose sexual descritos pelos sexólogos do século XIX, sem solicitação de mudança de sexo. ${ }^{153}$

Sob esse aspecto, a transexualidade é um fenômeno social que pode ser considerado um sintoma da civilização moderna, pois o pedido dos transexuais de modificação do próprio corpo para sua conformação à aparência do sexo oposto supõe uma prévia oferta introduzida pela ciência, possibilitada pelo avanço da tecnologia e da técnica no mundo moderno. De fato, "Nada de transexual sem cirurgião e sem endocrinologista". 154

A primeira menção à palavra transexual foi ocasional, pelo sexólogo alemão Magnus Hirschfeld, em 1923, sob a forma seelischer Transsexualism; atribuindo-se a D.O. Cauldwell a descrição do fenômeno com o sentido atual, em artigo intitulado Psychopathia transexualis, de 1949, em que relatava um caso de transexual

152 Boletim ICAPS, junho de 2005, n. 231, p. 8 .

${ }^{153}$ Millot, Catherine. Extrasexo: ensaio sobre o transexualismo. Tradução de Maria Celeste Marcondes e Nelson Luis Barbosa. São Paulo: escuta, 1992, p. 17 e 121.

${ }^{154}$ Idem, p. 17. 
feminino para masculino. ${ }^{155}$ A nomenclatura atual, transexualismo, é atribuída por Collette Chiland e Catherine Millot a Harry Benjamin, ${ }^{156}$ cunhada nos anos cinquenta, posto que não utilizada em artigo dos anos quarenta, sobre o assunto, denominado "Forma epidêmica de um mal antigo", 157

Para Edvaldo Souza Couto, "O transexual é aquele que recusa totalmente o sexo que lhe foi atribuído civilmente. Identifica-se psicologicamente com o sexo oposto, embora biologicamente não seja portador de nenhuma anomalia. Geralmente possui genitália perfeita, interna e externa, de um único sexo, mas a nível psicológico responde a estímulos de outro. Costumam considerar-se um "erro da natureza", ${ }^{158}$

Acentua Collette Chiland que não se trata de mero mal-estar ou desconforto, mas recusa total ao sexo de atribuição, que é lhe inaceitável e fonte de horror. 159

Os autores que enfrentaram o tema no direito incorporaram as lições da área da saúde.

Para Maria Helena Diniz, a transexualidade implica um drama jurídico-existencial, decorrente da cisão entre a identidade sexual física e a identidade psíquica, drama esse que transcende o incômodo psicológico e leva à efetiva rejeição do fenótipo, resultando em tendência à automutilação, genital ou dos seios, ou ao autoextermínio. $^{160}$

Para Aracy Klabin, o transexual é um indivíduo anatomicamente de um sexo que acredita pertencer ao outro. Nas palavras da autora: "Esta crença é tão forte que o faz obcecado pelo desejo de ter o corpo alterado, a fim de ajustar-se ao 'verdadeiro' sexo, isto é, ao seu sexo psicológico". ${ }^{161}$

Após assentar que o transexual é um indivíduo biologicamente perfeito, mas que acredita pertencer ao sexo contrário à sua anatomia e não se reconhece no próprio corpo, Antonio Chaves conclui que se comportar de acordo com o sexo

\footnotetext{
${ }^{155}$ SAADEH, Alexandre. Boletim ICAPS, junho de 2005, n. 231, p. 8.

${ }^{156}$ CHILAND, Colette. O transexualismo. Tradução de Maria Stela Gonçalves. Edições Loyola, 2008, p. 12 e MILLOT, Catherine. Extrasexo: ensaio sobre o transexualismo. Tradução de Maria Celeste Marcondes e Nelson Luis Barbosa. São Paulo: Escuta, 1992, p. 43.

${ }^{157}$ MILLOT, Catherine. Extrasexo: ensaio sobre o transexualismo, cit., p. 17.

${ }^{158}$ Transexualidade: o corpo em mutação. Salvador: Editora GGB, 1999, p. 26.

${ }^{159}$ CHILAND, Colette. O transexualismo, cit., p. 42.

160 DINIZ, Maria Helena. O estado atual do biodireito, p. 250/251; RIOS, Roger Raupp. Direito da Antidiscriminação, Sexo, Sexualidade e Gênero: a Compreensão da Proibição Constitucional de Discriminação por Motivo de Sexo. In Sarmento, Daniel, Ikawa, Daniela e Piovesan, Flavia. Igualdade, Diferença e Direitos Humanos. Rio de Janeiro: Lúmen Juris, 2008, p. 706.

161 Aspectos jurídicos do transexualismo. In Revista da Faculdade de Direito da Universidade de São Paulo. Vol. 90, 1995, p. 203.
} 
biológico lhe é estressante, podendo chegar ao ponto da automutilação da genitália e até do suicídio. $^{162}$

Elimar Szaniawski, com base nas lições da medicina, afirma que a transexualidade é uma anomalia da sexualidade humana pela inversão da identidade psicossocial do indivíduo, caracterizada por um sentimento difuso e profundo de pertencer ao sexo oposto e a vontade extremada de reversão sexual. ${ }^{163}$

No Dicionário Jurídico, Maria Helena Diniz assim define o transexual:

"Transexual: Medicina legal e psicologia forense. 1. Aquele que não aceita o seu sexo, identificando-se psicologicamente com o sexo oposto (Hojda), sendo, portanto, um hermafrodita psíquico (H. Benjamin). 2. Aquele que, apesar de aparentar ter um sexo, apresenta constituição cromossômica do sexo oposto e mediante cirurgia passa para outro sexo (Othon Sidou). Tal intervenção cirúrgica para a mulher consiste na retirada dos seios, fechamento da vagina e confecção de pênis artificial e, para o homem, na emasculação e posterior implantação de uma vagina (Paulo Matos Peixoto). 3. Para a Associação Paulista de Medicina, é o indivíduo com identificação psicossexual oposta aos seus órgãos genitais externos, com o desejo compulsivo de mudá-los. 4. Aquele que, tendo morfologia genital masculina, sente-se psicologicamente mulher, rejeitando seu papel de gênero masculino até buscar a alteração de sua anatomia para assumir aparência física feminina. Correspondentemente, há mulheres em situação análoga (Aldo Pereira)". 164

Matilde Josefina Sutter, com apoio no cirurgião Roberto Farina, distingue entre o transexual primário e o secundário, com base na estabilidade do desejo de mudança de sexo. Enquanto o transexual primário apresenta uma obsessão de mudança de sexo "compulsiva, precoce, imperativa e perene", o transexual secundário alterna fases de atividade homossexual e travestismo, "apresentando impulsos transitórios e ocasionais de transexualidade". 165

Essa distinção acabou adotada por vários outros autores, com base na estabilidade da convicção de pertencer ao gênero oposto ao do sexo biológico, e consta inclusive no Dicionário Jurídico. Maria Helena Diniz assim define o transexualismo secundário: "Transexualismo secundário: Psicologia forense e medicina legal. É transitório

\footnotetext{
${ }^{162}$ CHAVES, Antônio. Direito à vida e ao próprio corpo. São Paulo: RT, 1994, p. 140.

${ }^{163}$ Limites e possibilidades do direito de redesignação do estado sexual. São Paulo: RT, 1998, p. 52.

${ }^{164}$ Dicionário Jurídico. São Paulo: Saraiva, vol. 4, 1998, p. 604.

${ }^{165}$ Determinação e mudança de sexo. Aspectos médico-legais. São Paulo: RT, 1993, p. 109.
} 
e traduz apenas uma transhomossexualidade, ou seja, um transexualismo episódico e fortuito (Roberto Farina)". ${ }^{166}$

Assim, o desejo expressado pelo transexual secundário é intermitente, variando de acordo com a circunstância, como ilustrado no exemplo de Colette Chiland. A psicanalista cita o caso de um paciente que provocou o crescimento de seus seios pela aplicação de hormônios, para agradar um companheiro. Mais tarde, por ele abandonado, pediu que lhe cortassem os seios e, finalmente, externou pretender recuperálos para satisfazer um novo amigo. ${ }^{167}$ A autora aponta que, diversamente, no transexual primário, o sujeito sentiu-se pertencer ao outro sexo desde a primeira infância, sem variação nem concessão ao sexo de atribuição. ${ }^{168}$

Diante da flutuação que caracteriza o transexual secundário, a doutrina classifica-o como transexual não verdadeiro, ${ }^{169}$ que em determinadas circunstâncias aproxima-se do homossexual e do travesti. ${ }^{170}$

Para Wiliam Siqueira Peres, psicólogo e professor da UNESP com experiência clínica com travestis e transexuais, a principal distinção entre travestis e transexuais consiste na demanda pela cirurgia de mudança de sexo e de identidade civil, que somente aparece nos transexuais, já que a aplicação de silicone e a ingestão de hormônios é comum a ambos. Já os transgêneros caracterizam-se esteticamente por orientação do gênero oposto, mas não se mantêm estáveis nessa caracterização, compondo o grupo dos drag queens e transformistas. A distinção entre os transgêneros e os transexuais, para o autor, consistiria exatamente na estabilidade da identificação com o gênero oposto. ${ }^{171}$ Nesse caso, os transgêneros corresponderiam aos transexuais secundários.

Yolanda Moreno, em nota, após identificar debate na doutrina e a utilização de várias nomenclaturas para a transexualidade (transexualismo, pessoa transexualizada, síndrome de Harry Benjamin, disforia de gênero, transtorno de identidade sexual, transtorno de identidade de gênero, transgênero, transgenerismo ou transgeneridade), reconhece que também se utiliza a palavra transgênero para referir às pessoas que, apesar de não se sentirem bem com o próprio sexo legal, não desejam uma

\footnotetext{
${ }^{166}$ Dicionário Jurídico, Saraiva, vol 4, 1998, p. 605.

${ }^{167}$ CHILAND, Colette. O transexualismo, cit., p. 48/49.

${ }^{168}$ Idem, p. 52.

${ }^{169}$ SUTTER, Matilde Josefina. Determinação e mudança de sexo. São Paulo: RT, 1993, p. 109.

${ }^{170}$ KLABIN. Aracy Augusta Leme. Aspectos jurídicos do transexualismo, cit., p. 206.

${ }^{171}$ Cenas de Exclusões Anunciadas: travestis, transexuais, transgêneros e a escola brasileira. In Diversidade Sexual na Educação: problematizações sobre a homofobia nas escolas. (Org) Junqueira, Rogério Diniz. Brasília: Ministério da Educação, UNESCO, 2009, p. 236.
} 
transformação completa ao sexo legal contrário, por sentirem que sua convicção pode se alterar no futuro, ${ }^{172}$ o que as aproximaria do transexual secundário.

Já Sonja Shield, em artigo denominado "O médico não vai atendê-lo agora: direitos dos adolescentes transgêneros ao tratamento de redesignação sexual" (tradução livre), ${ }^{173}$ utiliza a palavra transgênero como sinônimo de transexual. A autora, ao definir a terminologia empregada, estabelece: "Neste artigo eu uso o termo transgênero para referir aos indivíduos cuja identidade de gênero difere do sexo físico atribuído pelo nascimento" (tradução livre), ${ }^{174}$ sem qualquer alusão específica à perenidade da convicção.

Para Colette Chiland, por sua vez, o transgenerismo estaria ligado à ocupação de lugar socialmente pertencente ao sexo oposto, sem a mudança de sexo propriamente dita. Mas a mesma autora alerta para o fato de que o sentido do termo transgênero ainda é indefinido: "ora engloba os transexuais, os travestis etc., ora designa aqueles que desejam mudar de gênero, e não de sexo, o que pode abranger hormônios sem cirurgia ou com uma cirurgia parcial, por exemplo, limitada a uma mamectomia, com uma mudança do nome". ${ }^{175}$ De todo modo, para a autora francesa, a distinção não se relacionaria à estabilidade da vivência como alguém do sexo oposto.

Neste trabalho, a transexualidade primária desperta interesse maior, pois é exatamente a estabilidade da identificação que leva à busca por uma nova identidade e produz reflexos diretos no direito, ensejando uma reflexão. Por isso, as referências que serão feitas no decorrer do desenvolvimento do tema versarão sobre o transexual primário.

Cabe, por fim, anotar que o reconhecimento da transexualidade não é isento de críticas.

Gilbert Hottois traz os argumentos daqueles que lhe são contrários, calcados no fato de que o diagnóstico médico se baseia essencialmente na percepção interna do paciente, sem se caracterizar como uma patologia propriamente dita,

${ }^{172}$ La transexualidad, cit., p. 29.

173 "The doctor won't see you now: rights of transgender adolescents to sex reassignment treatment". Disponível www.law.nyu.edu/ecm_dlv4/groups/public/@nyu_law_website_law_and_social_change/documents/docume nts/ecm_pro_064020.pdf, último acesso em 13/12/2011.

${ }_{174}$ "In this article I use the term transgender to refer to individuals whose gender identity differs from the physical sex they were assigned at birth". Disponível em: www.law.nyu.edu/ecm_dlv4/groups/public/@ nyu_law_website_law_and_social_change/documents/docume nts/ecm_pro_064020.pdf, último acesso em 13/12/2011.

${ }^{175} \mathrm{O}$ transexualismo, cit., p. 128. 
sendo que a medicina e a sociedade não devem dar sequência às monomanias individuais. Acrescenta que "o tratamento médico-cirúrgico é extremamente pesado, mutilador e irreversível, e não pode ser considerado terapêutico pois é incapaz de dar ao transexual mais do que a mera aparência do outro sexo". ${ }^{176}$

A posição contrária ao reconhecimento da transexualidade é largamente minoritária, tratando-se de fenômeno reconhecido pela comunidade internacional, tanto assim que está catalogada pela Classificação Internacional das Doenças, $10^{\mathrm{a}}$ versão, CID 10, F64, existindo inclusive diretrizes para o diagnóstico do transexual:

"Transexualismo. Trata-se de um desejo de viver e ser aceito como pessoa pertencente ao sexo oposto. Esse desejo é habitualmente acompanhado de um sentimento de mal-estar ou de inadaptação ao próprio sexo anatômico e da vontade de submeter-se a uma intervenção cirúrgica ou a um tratamento hormonal a fim de tornar o corpo na maior conformidade possível com o sexo desejado. Diretrizes para o diagnóstico. Para fazer esse diagnóstico a identidade de tipo transexual deve ter estado presente de uma maneira persistente durante ao menos dois anos, não ser um sintoma de outra perturbação mental, tal como uma esquizofrenia, e não estar associada a outra anomalia sexual genética ou cromossômica". A Associação Americana de Psiquiatria igualmente indica critérios para o diagnóstico da perturbação de identidade sexual, nos códigos 302.6 e 302.85, do DMS-IV (Diagnostic and Statistcs Manual). São quatro os critérios de diagnóstico: 1) identificação intensa e persistente com o outro sexo; 2) sentimento persistente de desconforto em relação ao próprio sexo ou sentimento de inadequação à identidade de papel (gender role) correspondente; 3) inexistência de hermafroditismo; e 4) sofrimento clinicamente significativo, ou alteração do funcionamento social, profissional ou de outros domínios importantes. ${ }^{177}$

\section{8) Critérios de diagnóstico e formas de tratamento da} transexualidade no Brasil: normas do Conselho Federal de Medicina e do Ministério da Saúde

No Brasil, a primeira regulamentação da transexualidade pelo Conselho Federal de Medicina é de 1997, Resolução nº 1.482. Essa Resolução foi

176 HOTTOIS, Gilbert. Missa, Jean-Nöel. Nova enciclopédia da bioética: medicina, ambiente e biotecnologia. Tradução de Maria Carvalho. Lisboa: Instituto Piaget, 2003. Verbete transexualismo, p. 652. ${ }^{177}$ CHILAND, Colette. O transexualismo, cit., p. 41/42. 
substituída pela Resolução CFM n ${ }^{\circ}$ 1.652/2002, expressamente revogada pela Resolução $\mathrm{CFM} \mathrm{n}^{\mathrm{o}} 1.955$, de 12/08/2010, atualmente em vigor. ${ }^{178}$

Pelo art. $3^{\circ}$, da Resolução $\mathrm{n}^{\mathrm{o}} 1.955 / 2010$, o diagnóstico do transexual deve observar, no mínimo, os seguintes critérios: 1) Desconforto com o sexo anatômico natural; 2) Desejo expresso de eliminar os genitais, perder as características primárias e secundárias do próprio sexo e ganhar as do sexo oposto; 3) Permanência desses distúrbios de forma contínua e consistente por, no mínimo, dois anos; 4) Ausência de outros transtornos mentais.

Acrescenta o art. $4^{\circ}$ que a seleção dos pacientes para a cirurgia de transgenitalismo obedecerá à avaliação de equipe multidisciplinar constituída por médico psiquiatra, cirurgião, endocrinologista, psicólogo e assistente social, após, no mínimo, dois anos de acompanhamento conjunto, devendo ser observados os seguintes critérios: 1) Diagnóstico médico de transgenitalismo; 2) Pessoa maior de 21 (vinte e um) anos; 3) Ausência de características inapropriadas para a cirurgia.

A norma administrativa editada pelo Conselho Federal de Medicina em agosto de 2010, destarte, ao regulamentar a realização da cirurgia plásticoreconstrutiva da genitália externa, interna e caracteres sexuais secundários, enumera critérios para a definição da transexualidade, que devem ser observados como condição para a realização da cirurgia.

$$
\text { Mas a cirurgia não é a única forma de tratamento }
$$
regulamentada. De fato, a possibilidade de tratamento diverso é expressamente prevista em norma do Ministério da Saúde do Brasil.

Em 18 de agosto de 2008, foi publicada a Portaria n. 1.707, do Ministério da Saúde, que institui "no âmbito do Sistema Único de Saúde (SUS) o Processo Transexualizador a ser empreendido em serviços de referência devidamente habilitados à atenção integral à saúde aos indivíduos que dele necessitem”, seguida da Portaria n. 457, da Secretaria de Atenção à Saúde do Ministério da Saúde.

Essa Portaria explicita que a aptidão para se submeter à cirurgia, diagnosticada após o prazo de acompanhamento de dois anos estabelecido nas Resoluções n. 1652/2002 e 1955/2010, não significa que o transexual deva necessariamente ser submetido ao tratamento cirúrgico.

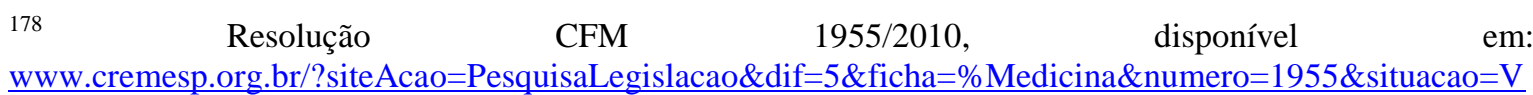
$\underline{\text { WWW.cremesp.org.br/?siteAcao=PesquisaLegislacao\&dif }=5 \& \text { IGENa }=12-08-2010, \text { último acesso em 12/12/2011. }}$ 
A Portaria é expressa ao consignar: "A cirurgia de transgenitalização deve ser concebida como um dentre outros recursos terapêuticos dos quais dispõe o indivíduo transexual em seu processo transexualizador", acrescentando que a escolha pela intervenção na genitália deve ser precedida de processo psicoterapêutico e social para proporcionar ao transexual: 1) conhecimentos sobre os aspectos cirúrgicos e seus resultados estéticos e funcionais; 2) consideração crítica das expectativas que acompanham a demanda de transgenitalização e das consequências estéticas e funcionais na intervenção cirúrgica na experiência pessoal e relacional do indivíduo transexual; e 3) considerações críticas de outras alternativas necessárias para melhoria da qualidade de vida.

Para alcançar tais objetivos, a Portaria incumbe os profissionais que compõem a equipe multidisciplinar de incitar o questionamento da demanda de transgenitalização, com especial atenção à função da transgenitalização de facilitação do processo de inclusão social, e não de mero atendimento a expectativas estéticas (Anexo III).

De acordo com a Portaria, é possível que seja feito o diagnóstico da transexualidade e que, mesmo assim, o tratamento não envolva a cirurgia de transgenitalização, optando-se por outros recursos terapêuticos, como ministrar hormônios. A Portaria não distingue entre o operado e o não operado, determinando que: "Em caso de internação hospitalar, o (a) transexual será internado (a) na enfermaria em conformidade ao sexo com o qual se identifica socialmente, a despeito do nome que conste no registro civil" (Anexo III).

\section{9) A pessoa transexual: transexualidade ou}

\section{transexualidades?}

A ideia universal e absoluta de transexualidade, típica do dogma científico, parece não encontrar respaldo na realidade constatada pelos pesquisadores de campo que desenvolveram pesquisas com transexuais.

Wiliam Siqueira Peres aponta para a necessidade de utilizar a referência aos travestis, transexuais e transgêneros (TTT) no plural, em combate a estereótipos e em respeito à individualidade de cada pessoa, pois "não podemos tomar um 
modo de ser e transformá-lo numa matriz reprodutiva, de modo fabril, em que todas as TTT's seriam vistas como cópias de uma única matriz". ${ }^{179}$

Catherine Millot, psicóloga francesa, concluiu seu estudo no mesmo sentido, reagindo à ideia de estabilidade da convicção dos transexuais: "Dizer que o transexualismo se baseia sobre o sentimento íntimo de ser mulher ou homem é uma das falsas certezas que os testemunhos dos transexuais vêm abalar. É uma outra certeza que é importante questionar. A certeza de que o remédio para o mal-estar dos transexuais só possa consistir na mudança de sexo", logo acrescentando: "O caráter monolítico de sua posição parece mítico. (...) sua identidade sexual estava longe de ser tão isenta de contradições quanto se pretendia". ${ }^{180}$

Idênticos os resultados encontrados por Berenice Alves de Melo Bento, em pesquisa de campo desenvolvida por três anos sobre a experiência transexual, a primeira parte em um hospital público brasileiro que realiza cirurgias de transgenitalização; e a segunda parte, em uma associação de pessoas transexuais em Valência, na Espanha.

Suas conclusões revelam o questionamento da concepção universalizada da transexualidade, segundo a qual o verdadeiro transexual desejaria necessariamente a cirurgia como condição para vivenciar sua sexualidade; e seria necessariamente heterossexual.

Segundo a autora, muitos transexuais entrevistados não queriam a cirurgia e reivindicavam exclusivamente a mudança nos documentos, baseados na aparência do gênero oposto, obtida com o uso de hormônios, silicone e maquiagem. ${ }^{181} \mathrm{O}$ desejo pela cirurgia, quando manifestado, igualmente não estava necessariamente ligado à sexualidade ou ao mal-estar com a própria anatomia. Vinculava-se, diversamente, à necessidade de reconhecimento da pessoa como parte de um determinado gênero, em busca de inteligibilidade social, como no exemplo de Andréa, cuja intenção de se submeter à operação justificava-se pelo constrangimento de tomar banho com outra mulher sem despertar dúvida quanto à sua identidade feminina. ${ }^{182}$ Nas palavras da pesquisadora: "Se a

\footnotetext{
${ }^{179}$ PERES, Wiliam Siqueira. Cenas de Exclusões Anunciadas: travestis, transexuais, transgêneros e a escola brasileira. In Diversidade Sexual na Educação: problematizações sobre a homofobia nas escolas. (Org) Junqueira, Rogério Diniz, cit., p. 258.

${ }^{180}$ MILLOT, Catherine, Extrasexo: ensaio sobre o transexualismo, cit., p. 121e p. 122

${ }^{181} \mathrm{Da}$ transexualidade oficial às transexualidades. In Piscitelli, Adriana; Gregori, Maria Filomena; Carrara, Sergio (orgs). Sexualidade e saberes: convenções e fronteiras. Rio de Janeiro: Garamond, 2004, p. 169.

182 BENTO, Berenice Alves de Melo. Da transexualidade oficial às transexualidades. In Piscitelli, Adriana; Gregori, Maria Filomena; Carrara, Sergio (orgs). Sexualidade e saberes: convenções e fronteiras. Rio de Janeiro: Garamond, 2004, p. 168
} 
sociedade divide-se em corpos-homens e corpos-mulheres, aqueles que não apresentam essa correspondência fundante tendem a estar fora da categoria do humano". ${ }^{183}$

Nessa quadra, parece necessário admitir mais de uma possibilidade de vivenciar o conflito que caracteriza a transexualidade, como corroborado pelos depoimentos dos transexuais.

Lea T, 28, filha de Toninho Cerezo, nasceu Leandro e tornou-se Lea, estrela de campanha da marca francesa Givenchy. Em entrevista à revista Veja afirmou que pretende fazer a cirurgia de mudança de sexo: "Sempre fui feminina. Dizia 'prazer, Leandro' e ficava aquele silêncio na sala". ${ }^{184}$

Diferentemente, Renato Fonseca, 43, nascido Rosane Oliveira da Fonseca, em depoimento para o jornal Folha de São Paulo, revelou que gostaria de extirpar os seios, mas não de se submeter à redesignação de sexo. Sobre o órgão sexual afirmou: "Minha esposa - sou casado há 11 anos com uma mulher muito feminina - diz que não tem necessidade de eu fazer a operação na parte de baixo. Ela já está bem contente [risos]". 185

Em relação ao desejo pela mudança de sexo nos homens transexuais, o urologista Carlos Cury, especialista na cirurgia de transgenitalização e entrevistado na mesma reportagem, informou que boa parte dos transexuais já se satisfaz em retirar os seios: "Isso já causa um impacto emocional, esses pacientes tem uma necessidade muito grande de se mostrar como homens". ${ }^{186}$

Diante de tais revelações, a tutela dos transexuais pela perspectiva dos direitos humanos, quer parecer, não prescinde de uma compreensão mais aberta da transexualidade, de modo a aceitar as diferentes manifestações do conflito em cada um.

Outra constatação que abala a abstração universal do transexual refere-se à sexualidade.

De acordo com as definições trazidas, o transexual não manteria relações sexuais enquanto não transformado, por conta da falta de prazer e do horror provocado pelo sexo anatômico, que o privaria de vida sexual. ${ }^{187}$

\footnotetext{
183 Idem, p. 170.

${ }^{184}$ Revista Veja, de 28/07/2010. Edição 2175, ano 43, n. 30, p. 102.

185 Jornal Folha de São Paulo, edição de 12/09/2010, p. C 15

${ }^{186}$ Idem, mesma página.

187 SZANIAWSKI. Elimar. Limites e possibilidades do direito de redesignação do estado sexual. São Paulo: RT, 1998, p. 56.
} 
Contudo, não foi o que a socióloga Berenice A. M. Bento verificou nas entrevistas, encontrando vários transexuais com uma vida sexual ativa, levando a pesquisadora a refletir: "Essas histórias desconstroem pouco a pouco a imagem de um sujeito transexual assexuado". 188

A distinção entre a transexualidade e a orientação sexual fica clara pela pesquisa de Berenice Bento, ao defender a desconstrução da categoria universal do transexual relacionada à heterossexualidade. Com base nos estudos de Robert Stoller e Henry Benjamin, sempre haveria no transexual a manifestação do desejo de se relacionar sexualmente com o sexo oposto àquele correspondente à sua identificação psíquica. Ou seja, um homem que se sentisse mulher desejaria se relacionar com homens, não porque fosse homossexual, mas em consequência da identidade de gênero manifestada, feminina, em busca de um parceiro do sexo oposto. Ocorre que a existência de transexuais gays e lésbicas indica uma nova categoria interna da experiência transexual: a das mulheres transexuais lésbicas, biologicamente homens, social e aparentemente mulheres, com desejos por outra mulher.

A partir daí, pode-se falar em radicalização dos deslocamentos iniciados pela experiência transexual, caracterizada pela divergência entre o sexo biológico e a identidade de gênero, acrescida de uma sexualidade deslocada de um referente biológico heterossexual. ${ }^{189}$

As assertivas das pesquisadoras, longe de negar a existência de transexuais ou a necessidade de abertura dos ordenamentos jurídicos para sua tutela, vêm apenas corroborar a impossibilidade de redução da pessoa humana a uma classificação estanque. De fato, tratando-se de conceito abstrato, pelo qual se pretende classificar o ser humano, não surpreende a divergência entre o modelo científico e a realidade concreta, a qual não pode ser desconsiderada no enfrentamento da questão.

Por isso, cabe repetir, neste estudo sobre a transexualidade na área de direitos humanos, a ênfase está no sofrimento experimentado pelos transexuais, sem a preocupação de esgotamento de todas as definições e conceitos fornecidos pela literatura das áreas da saúde e sociologia, em respeito à complexidade humana impossível de ser descrita e esgotada pela ciência.

\footnotetext{
${ }^{188}$ BENTO, Berenice Alves de Melo. Da transexualidade oficial às transexualidades. In Piscitelli, Adriana; Gregori, Maria Filomena; Carrara, Sergio (orgs). Sexualidade e saberes: convenções e fronteiras, cit., p. 164.

${ }^{189}$ Idem, p. 166.
} 
No mais, suficientemente constatada a existência de pessoas que enfrentam graves contradições entre o sexo biológico e a identidade de gênero, de forma permanente, estável e intensa, objetiva-se encontrar meios para a tutela efetiva de seus direitos, em respeito à sua dignidade.

\section{0) Transexualidade: questão de identidade de gênero e não}

\section{de orientação sexual}

Roger Raupp Rios, forte na lição de Elizabeth Zambrano, afirma: "É muito comum homossexuais, travestis e transexuais serem percebidos como fazendo parte de um mesmo grupo, numa confusão entre a orientação sexual (homossexualidade, heterossexualidade, bissexualidade) e as 'identidades de gênero' (homens masculinos, mulheres femininas, travestis, transexuais femininos e masculinos, entre outras)". 190

Nessa quadra, relevante deixar clara a diferença entre a orientação sexual, que define homossexuais, heterossexuais e bissexuais, e a identidade de gênero, cujo conflito caracteriza os transexuais, com o objetivo de encontrar os mais eficientes meios de tutela dos direitos dos transexuais. Almeja-se, assim, contribuir para o incremento da tolerância, já que o reconhecimento do diferente é condição e antecedente lógico do respeito à diferença.

$\mathrm{Na}$ definição dos relatores dos Princípios de Yogyakarta, a orientação sexual refere-se "à capacidade de cada pessoa de sentir uma profunda atração emocional, afetiva e sexual, por pessoas de um gênero diferente ao seu, de seu mesmo gênero, ou de mais de um gênero, assim como a capacidade de manter relações íntimas e sexuais com estas pessoas" (tradução livre). ${ }^{191} \quad$ A identidade de gênero, por sua vez, refere-se "à vivência interna e individual de gênero, a como cada pessoa se sente profundamente, a qual pode ou não corresponder ao sexo adquirido pelo nascimento, incluindo a vivência pessoal do corpo (que pode incluir a modificação da aparência ou da função corporal através de meios médicos, cirúrgicos, ou de outra índole, sempre que a

\footnotetext{
${ }^{190}$ Direito da Antidiscriminação, Sexo, Sexualidade e Gênero: a Compreensão da Proibição Constitucional de Discriminação por Motivo de Sexo. In SARMENTO, Daniel, IKAWA, Daniela e PIOVESAN, Flavia. Igualdade, Diferença e Direitos Humanos. Rio de Janeiro: Lúmen Juris, 2008, p. 716.

191 "La orientación sexual se refiere a la capacidad de cada persona de sentir una profunda atracción emocional, afectiva y sexual por personas de un género diferente al suyo, o de su mismo género, o de más de un género, así como a la capacidad mantener relaciones intimas y sexuales con estas personas”. In Introducción a los princípios de yogyakarta, p. 6, nota (1). Disponível em:www.yogyakartaprinciples.org/principles_sp.pdf, último acesso em 02/01/2012.
} 
mesma seja livremente escolhida) e outras expressões de gênero, incluindo a vestimenta, o jeito de falar e os modos" (tradução livre). ${ }^{192}$

A orientação sexual refere-se, então, à forma pela qual o sujeito vivencia sua sexualidade e encontra prazer, dirigindo a atração sexual do indivíduo para pessoa do mesmo sexo, no caso da homossexualidade, ou para pessoa do sexo oposto, na denominada heterossexualidade, ou ainda alternativamente, na bissexualidade. Não há qualquer conflito identitário. A pessoa percebe-se como alguém do sexo biológico, aceitando a ele pertencer, havendo harmonia entre a identidade pessoal e a identidade sexual.

O conflito de identidade de gênero que caracteriza a transexualidade, diversamente, implica uma dissociação entre o sexo biológico e o gênero, ou o papel social com o qual a pessoa se identifica e assume no curso da vida.

Nas palavras da psicóloga Marlene Inácio, que acompanha pessoas com ambiguidade sexual no Hospital das Clínicas há vinte e oito anos, "a identidade de gênero é ser e ao mesmo tempo sentir-se homem ou mulher", ${ }^{193} \mathrm{em}$ contrariedade com o sexo biológico. Daí afirmar-se que, na experiência transexual, "o gênero está em disputa com o corpo-sexuado". ${ }^{194}$

Por isso, pode-se falar, como visto, em transexuais hetero, homo, ou bissexuais, em clara demonstração da independência entre os conteúdos da orientação sexual e da identidade de gênero, do que resulta a necessidade de "interpretar a identidade de gênero, a sexualidade, a subjetividade e o corpo como modalidades relativamente independentes". 195

Pelos fins propostos, este trabalho não aprofunda o tema da orientação sexual, centrando-se a pesquisa na ideia de transexualidade como uma identificação da pessoa com o gênero oposto: uma pessoa nascida em corpo masculino que se sente mulher, ou vice-versa, independentemente da orientação sexual assumida.

\footnotetext{
192 "La identidad de género se refiere a la vivencia interna e individual del género tal como cada persona la siente profundamente, la cual podría corresponder o no con el sexo asignado al momento del nacimiento, incluyendo la vivencia personal del cuerpo (que podría involucrar la modificación de la apariencia o la función corporal a través de medios médicos, quirúrgicos o de otra índole, siempre que la misma sea libremente escogida) y otras expresiones de género, incluyendo la vestimenta, el modo de hablar y los modales”. In Introducción a los princípios de yogyakarta, p. 6, nota (2). Disponível em:www.yogyakartaprinciples.org/principles_sp.pdf, último acesso em 02/01/2012.

193 Apud FIORAVANTI, Carlos. Limites Incertos. Grupo de pesquisa paulista caracteriza 23 disfunções orgânicas do desenvolvimento sexual. In Revista de Pesquisa FAPESP, n 170, abril de 2010, p. 21.

${ }^{194}$ BENTO, Berenice Alves de Melo. Da transexualidade oficial às transexualidades. In Piscitelli, Adriana; Gregori, Maria Filomena; Carrara, Sergio (orgs). Sexualidade e saberes: convenções e fronteiras, cit., p. 169.

${ }^{195}$ Idem, p. 171.
} 
Isso porque, em que pese a relevância da experiência sexual para o desenvolvimento da personalidade e sua inegável natureza de direito fundamental da pessoa humana, o enfrentamento da questão proposta, do modo em que se a percebe, depende menos da orientação sexual em si e mais da relação entre a identidade de gênero e seu reconhecimento jurídico-social, no pressuposto de que a transexualidade, nas palavras da psicanalista Norma Lottenberg Semer, "É mais um problema de identidade do que de sexualidade". ${ }^{196}$

Bem por isso, o desenvolvimento do tema pela ótica dos direitos humanos, voltado ao reconhecimento jurídico da identidade sexual ou de gênero entre os direitos da personalidade, prescinde do aprofundamento da orientação sexual da pessoa, restrita à sua intimidade.

\section{1) Breves noções sobre gênero}

Assumida a premissa da identidade de gênero como o ponto central da transexualidade, necessário tecer breves considerações sobre o conceito de gênero.

Na lição de Judith Butler, as normas de gênero, enraizadas na cultura, explicam nossa noção de masculino e feminino e atuam como um pano de fundo sob a superficial aparência idealizada dos gêneros. As pessoas passam a atuar de acordo com os padrões de determinado gênero e a observância dessa regulamentação opera como condição de inteligibilidade cultural do sujeito entre seus pares. ${ }^{197}$

Daí a relevância da coerência entre o gênero do indivíduo e as normas por ele observadas. Contudo, para a definição do gênero não concorrem apenas elementos físico-biológicos.

A perspectiva de gênero é sempre relacional, baseada em uma categoria social construída historicamente, na qual se inserem as relações entre homens e mulheres em espaços e momentos temporais concretos. Transcende as características naturais que definem os sexos, envolvendo uma visão de mundo, a qual sintetiza

\footnotetext{
${ }^{196}$ Apud FIORAVANTI, Carlos. Limites Incertos. Grupo de pesquisa paulista caracteriza 23 disfunções orgânicas do desenvolvimento sexual. In Revista de Pesquisa FAPESP, n 170, abril de 2010, p. 21.

${ }^{197}$ Undoing Gender. New York: Routledge, 2004, p. 52.
} 
idealmente as diferenças, os contrastes e as especificidades concretas do fenômeno estudado. $^{198}$

Para elucidar o conceito, vale transcrever trecho da socióloga Berenice Alves de Melo Bento: "O gênero só existe na prática, na experiência, e sua realização se dá mediante reiterações cujos conteúdos são interpretações sobre o masculino e o feminino (...). O ato de pôr uma roupa, escolher uma cor, acessórios, o corte de cabelo, a forma de andar, enfim, a estética e a estilística corporais são atos que fazem o gênero, que visibilizam e estabilizam os corpos na ordem dicotomizada dos gêneros". 199

Assim, parece claro que o corpo físico não é a única variante que atua na determinação do gênero da pessoa, existindo uma intersecção entre o que herdamos geneticamente e o que aprendemos como sujeitos de uma determinada cultura.

Nesse sentido, enfatiza Dagmar E. Estermann Meyer que "intersecção" difere de "adição": "não é a cultura adicionada a uma natureza preexistente, mas uma imbricação em que nossa materialidade é invadida, nomeada, descrita e moldada pelos processos de significação - dentre eles os processos de significação de gênero - que configuram os mundos plurais em que vivemos e nos movimentamos". ${ }^{200}$

Após apontar para uma concepção de sexo como algo complexo, resultante da interação de fatores biológicos, sociológicos e jurídico-sociais, Sessarego sugere uma distinção entre gênero e sexo. Defende que se utilize a expressão sexo para se referir aos aspectos anatômicos e fisiológicos, reservando à palavra gênero um conteúdo mais amplo, compreendido como: "tudo aquilo de inato e de adquirido, encontrado na sexualidade humana, em determinado momento sociológico e cultural” (tradução livre). ${ }^{201}$

Bem por isso, os caracteres biológicos adquiridos pelo nascimento afiguram-se insuficientes para garantir o pertencimento da pessoa ao gênero correspondente, haja vista que a identificação ao gênero não prescindirá da experiência da pessoa como membro de uma determinada comunidade.

198 FLORES. Joaquín Herrera Flores. La construcción De Las Garantías. Hacia Una Concepción Antipatriarcal De La Libertad Y La Igualdad. In SARMENTO, Daniel, IKAWA, Daniela e PIOVESAN, Flavia. Igualdade, Diferença e Direitos Humanos. Rio de Janeiro: Lúmen Juris, 2008, p. 122.

${ }^{199}$ BENTO, Berenice Alves de Melo. Da transexualidade oficial às transexualidades. In Piscitelli, Adriana; Gregori, Maria Filomena; Carrara, Sergio (orgs). Sexualidade e saberes: convenções e fronteiras, cit., p. 144.

200 Corpo, violência e educação: uma abordagem de gênero. In Diversidade Sexual na Educação: problematizações sobre a homofobia nas escolas. (Org) Junqueira, Rogério Diniz. Brasília: Ministério da Educação, UNESCO, 2009, p. 218.

201 "todo aquello que deinnato y de adquirido se encuentra en la sexualidad humana y, sobre todo, el momento sicológico y cultural”. SESSAREGO, Carlos Fernández. El cambio de sexo y su incidencia en las relaciones familiares. In Revista de Direito Civil, Imobiliário, Agrário e Empresarial. Ano 15, vl. 56, abriljunho/1991, p. 8. (7-50). 
A partir daí, pode-se definir a identidade de gênero como: "a forma de um indivíduo se perceber e ser percebido pelos outros como masculino ou feminino, de acordo com os significados desses termos construídos pela cultura à qual pertence". 202

A noção de gênero, porque calcada em padrões culturais, remete à noção de standards, definidos por Larenz como "pautas normais de comportamento social correcto, aceites na realidade social", ${ }^{203}$ tratando-se de ideias consolidadas em cada cultura sobre o que é ser do sexo masculino e o que é ser do sexo feminino, em um certo tempo e espaço.

Outra abordagem sobre a identificação sexual pode ser trazida, agora com base na psicanálise.

Segundo Collette Chiland, o núcleo da identidade sexuada constrói-se nos três primeiros anos de vida, ligado ao sentimento de ser macho ou fêmea, desenvolvendo-se em seguida o sentimento de que se é masculino ou feminino, de acordo com o padrão de determinada cultura. ${ }^{204}$

Para a psicologia, a diferença entre os sexos remete ao simbólico e a suas bipartições, e ao imaginário que fixa os papéis feminino e masculino. Nessa medida, ela representa algo incontornável, pertencente à ordem do irredutível, ${ }^{205}$ naquilo que envolve o intangível.

Por isso, a ideia que serve de paradigma às mulheres transexuais, no processo de identificação com o universo feminino, é aquela da mulher conformada aos papéis de vedete e doméstica, na assimilação de um estereótipo sexual de submissão, ${ }^{206}$ o que demonstra o simbolismo no processo de identificação de gênero.

Pelo até aqui exposto, pode-se concluir que a concepção de gênero envolve uma remissão a padrões de comportamento entendidos como referências do significado de pertencer ao gênero masculino ou feminino, em cada cultura.

Em regra, pode-se afirmar que o gênero coincide com o sexo biológico da pessoa.

\footnotetext{
202 ZAMBRANO, Elizabeth. In Lima, Antônio Carlos de Souza (org), Antropologia e Direito: Bases para um Diálogo Interdisciplinar, Brasília, Associação Brasileira de Antropologia, 2007, apud RIOS, Roger Raupp. Direito da Antidiscriminação, Sexo, Sexualidade e Gênero: a Compreensão da Proibição Constitucional de Discriminação por Motivo de Sexo. In SARMENTO, Daniel, IKAWA, Daniela e PIOVESAN, Flavia. Igualdade, Diferença e Direitos Humanos. Rio de Janeiro: Lúmen Juris, 2008, p. 715.

${ }^{203}$ Metodologia da ciência do direito, cit., p. 660.

${ }^{204}$ CHILAND, Colette. O transexualismo, cit., p. 109.

${ }^{205}$ MILLOT, Catherine. Extrasexo: ensaio sobre o transexualismo, cit., p. 15.

${ }^{206}$ Idem, p. 14
} 
No caso do transexual, diversamente, o indivíduo identifica-se com o gênero oposto àquele correspondente ao seu sexo biológico, por causas ainda não perfeitamente elucidadas.

\section{2) Teorias sobre as causas da transexualidade}

A transexualidade desafia diversas áreas do conhecimento e a ciência ainda não identificou precisamente a explicação para a rejeição do gênero correspondente ao sexo, pelo indivíduo sadio do ponto de vista biológico.

Inegáveis as contribuições de dois autores, Harry Benjamin, endocrinologista, e Stoller, psicanalista, referências comuns nos trabalhos sobre transexuais. Trata-se de abordagens diferentes e complementares, uma mais psicanalítica, apoiada em Stoller, e outra biológica, baseado em Benjamin. Em razão da área de concentração, direitos humanos, foram buscadas fontes indiretas, sem maior preocupação com a literatura médica propriamente dita.

A análise de Berenice Alves de Melo Bento auxilia a compreender como e em que se distinguiram as pesquisas e propostas de cada um desses dois autores,

Atribui-se a Harry Benjamin a escola biológica sobre a transexualidade, atualmente representada pelo cientista holandês Jos Megens, membro da principal associação de pesquisas aplicadas sobre transexualidade, a Associação Internacional Harry Benjamin de Disforia de Gênero (WPATH - World Professional Association for Transgender Health, formalmente conhecida como HBIADG - Harry Benjamin International Gender Disphoria Association).

Para Benjamin, na lição de Berenice Alves de Melo Bento, o sexo é composto de vários sexos: o cromossômico ou genético, o gonádico, o fenotípico, o psicológico e o jurídico, reservando-se papel fundamental ao primeiro (XX ou XY) na determinação da identidade de gênero. ${ }^{207} \mathrm{O}$ transexual apresentaria uma oposição no sexo psicológico, o mais flexível entre os sexos, ${ }^{208}$ tratando-se de percepção íntima e interna do ser consigo mesmo, sem sinais biológicos de desajuste.

\footnotetext{
${ }^{207}$ BENTO, Berenice Alves de Melo. Da transexualidade oficial às transexualidades. In Piscitelli, Adriana; Gregori, Maria Filomena; Carrara, Sergio (orgs). Sexualidade e saberes: convenções e fronteiras, cit., p. 159.

${ }^{208}$ Idem, p. 161.
} 
Talvez por isso, o autodiagnóstico é considerado legítimo dentro dessa matriz teórica, defendendo-se a cirurgia como a única terapia possível. ${ }^{209}$ Como afirma Collette Chiland, Harry Benjamin passou a ministrar hormônios para aliviar o sofrimento de seus pacientes, diante do sintoma de identificação com o gênero oposto, afirmando que a psicoterapia era impotente. ${ }^{210}$

$\mathrm{Na}$ avaliação de Benjamin, o transexual é assexuado, no sentido de repudiar seu órgão sexual e não conseguir tocá-lo, e deseja a cirurgia tanto para desfrutar do status social do gênero com o qual se identifica, quanto para exercer sua sexualidade com o órgão apropriado. ${ }^{211}$

Em que pese a inegável contribuição de Harry Benjamin, Catherine Millot atribui a estruturação do transexualismo a Stoller, que identificou sua origem no momento de formação do núcleo fundamental da identidade de gênero, em oposição ao sexo biológico, ${ }^{212}$ aprofundando uma abordagem psicanalítica.

Segundo Berenice Bento, Stoller, no livro A experiência transexual, escrito em 1975, desenvolve sua teoria sobre a transexualidade com base na análise da relação do transexual com sua mãe, na infância, a partir da matriz freudiana, propondo que a criança seja submetida a intensa terapia como forma de integrá-la ao gênero correspondente a seu sexo biológico.

Denomina o tratamento de “complexo de Édipo terapeuticamente induzido", ${ }^{213}$ sustentando a possibilidade de recuperação da masculinidade mediante a terapia. Segundo Stoller, nesse caso, teria ocorrido o sucesso do desempenho do terapeuta como “..representante da sociedade, da saúde, e de conformidade com a realidade externa". 214

No testemunho de Catherine Millot, os transexuais efetivamente passaram a questionar seu desejo de transformação corporal, após o uso das técnicas de sugestão, hipnose, terapias comportamentais e de condicionamento: "Funciona: os transexuais são sensíveis à sugestão. Chegam a colocar em questão sua identidade

\footnotetext{
${ }^{209}$ Idem, mesma página.

${ }^{210}$ CHILAND, Colette. $O$ transexualismo, cit., p. 12.

${ }^{211}$ BENTO, Berenice Alves de Melo. Da transexualidade oficial às transexualidades. In Piscitelli, Adriana; Gregori, Maria Filomena; Carrara, Sergio (orgs). Sexualidade e saberes: convenções e fronteiras, cit., p. 163.

${ }^{212}$ MILLOT, Catherine. Extrasexo: ensaio sobre o transexualismo. Tradução de Maria Celeste Marcondes e Nelson Luis Barbosa, cit., p. 43.

${ }^{213}$ BENTO, Berenice Alves de Melo. Da transexualidade oficial às transexualidades. In Piscitelli, Adriana; Gregori, Maria Filomena; Carrara, Sergio (orgs). Sexualidade e saberes: convenções e fronteiras, cit., p. 153.

${ }^{214}$ Idem, p. 154.
} 
transexual, assim como sua escolha do objeto sexual e renunciam, ao menos provisoriamente, a uma transformação hormonal e cirúrgica". ${ }^{215}$

A experiência de Colette Chiland aparentemente confirma a tese de existirem causas relacionais, independentes de fator biológico, a partir do tratamento de crianças pequenas que recusavam o sexo de atribuição e que passaram a aceitá-lo por meio do atendimento da criança e de seus pais. ${ }^{216}$

Por outro lado, admitia Stoller que, se não houvesse intervenção nos primeiros anos de vida, em tempo de corrigir os rumos da identidade de gênero pela terapia, o tratamento ficaria comprometido. ${ }^{217}$

Essa ideia de Stoller é bastante difundida, sintetizada pela noção de inexistência de cura para a transexualidade no adulto, a quem a única alternativa viável seria a cirurgia.

As pesquisas de Stoller e Benjamin, desenvolvidas a partir dos anos cinquenta, permanecem referências no estudo da transexualidade, pouco se tendo avançado no sentido de encontrar uma única explicação para a transexualidade, provavelmente resultante da interação de várias causas.

O Prof. Roberto Farina, citado por Antonio Chaves, aproxima-se da visão de Benjamin, afirmando que a criança já nasce transexual, com horror à sua genitália e jamais buscando um companheiro homossexual, pois está identificada com o outro sexo desde a infância, o que, no entanto, se aplica somente ao transexual primário. ${ }^{218}$ Jole Baldaro Verde ${ }^{219}$ e Alessandra Graziottin, ${ }^{220}$ após afirmarem que a transexualidade consiste na forma mais extrema e inquietante de disforia de gênero, caracterizada pelo progressivo deslocamento do sentimento de identidade até a identificação com o outro sexo, concluem que provavelmente resulte de uma complexa interação entre fatores pré e pós-natais, biológicos e psicológicos. ${ }^{221}$

\footnotetext{
${ }^{215}$ MILLOT, Catherine, Extrasexo: ensaio sobre o transexualismo. Tradução de Maria Celeste Marcondes e Nelson Luis Barbosa, cit., p. 122.

${ }^{216}$ CHILAND, Colette. O transexualismo, cit., p. 35.

${ }^{217}$ BENTO, Berenice Alves de Melo. Da transexualidade oficial às transexualidades. In Piscitelli, Adriana; Gregori, Maria Filomena; Carrara, Sergio (orgs). Sexualidade e saberes: convenções e fronteiras, cit., p. 159.

${ }^{218}$ CHAVES, Antonio. Direito à vida e ao próprio corpo, cit., p. 144.

219 Doutora em estudos literários e em medicina e cirurgia e professora de teorias da personalidade na Universidade de Gênova e na Escola Superior para a Pesquisa e a Formação em Sexologia de Gênova.

${ }^{220}$ Ginecologista oncologista e terapeuta em sexologia.

221 Transexualismo. O enigma da identidade. Tradução de Sérgio Schirato. São Paulo: Paulus, 1997, p. 174.
} 
No mesmo sentido, da impossibilidade de explicação da origem da transexualidade, as conclusões de Maria Helena Diniz, após ampla pesquisa na literatura médica.

A autora cita as causas apontadas por diversos autores, naturais e sociais, ora afirmando que o transexual apresenta anomalia na estrutura nervosa central, desenvolvida durante o estado embrionário; sofre impregnação hormonal no hipotálamo, pelo hormônio contrário, nos últimos dias de vida fetal ou nas primeiras semanas de vida; apresenta alteração numérica ou estrutural dos cromossomos sexuais; possui testículo fetal pouco funcionante; decorre da ingestão de substâncias pela gestante; ou de insensibilidade dos tecidos ao hormônio masculino; ora indicando a origem da transexualidade no estresse inusitado da gestante; ou em fatores ambientais adversos, com prejuízo da identificação da criança com a figura materna ou paterna na infância, ${ }^{222}$ ou seja, ora explicando a transexualidade com base em fatores biológicos, ora em causas psicológico-sociais, a indicar a atualidade dos estudos de Benjamin e Stoller.

Elimar Szaniawski, por sua vez, localiza a origem da transexualidade por volta dos dois primeiros anos de vida, antes do desenvolvimento da capacidade de discernimento pela criança, ou até mesmo antes do nascimento, durante o período fetal. $^{223}$

Cabe ainda trazer, a título de ilustração, a teoria neurológica, inspirada em Benjamin e formulada pelos holandeses, que conta com bastante aceitação ao explicar a transexualidade a partir do tamanho da região do cérebro em que se desenvolvem os hormônios sexuais:

"Estudando o hipotálamo de cadáveres, região do cérebro responsável pelo desenvolvimento dos hormônios sexuais, os cientistas descobriram que uma parte chamada estria terminal é em média $44 \%$ maior nos homens do que nas mulheres. Ao medir a região em seis transexuais, os pesquisadores descobriram volumes até $52 \%$ menores do que a média masculina. Portanto, a região cerebral ligada à evolução da sexualidade seria, nos transexuais, mais próxima à das mulheres do que à dos homens".224

\footnotetext{
${ }^{222} \mathrm{O}$ estado atual do biodireito, p. 251/252.

${ }^{223}$ Limites e Possibilidades do Direito de Redesignação do Estado Sexual, p. 50.

${ }^{224}$ WEIS, Bruno. No corpo certo. Revista IstoÉ, São Paulo, 29/07/1998.
} 
Pelo exposto, parece correto afirmar que não há uma única causa que explique a transexualidade, tanto mais porque manifestada de diversas formas e em diferentes épocas da vida da pessoa.

Por outro lado, independentemente da indicação precisa da origem, os autores citados, das variadas escolas, não negam a existência de pessoas transexuais, cujo sofrimento é real, tratando-se da perspectiva deste estudo, voltado à promoção de seus respectivos direitos.

\section{3) A cirurgia para a mudança de sexo e a dignidade}

\section{humana: uma alternativa de tratamento a critério do paciente}

$\mathrm{O}$ direito ao corpo tornou-se palco de confronto à luz do desenvolvimento tecnológico, numa sociedade plural como a nossa, em que confluem valores religiosos, morais, sociais, culturais e científicos, muitas vezes apontando para sentidos diversos, o que coloca a bioética no centro da discussão.

A abertura, generalidade e abstração que caracterizam os princípios jurídicos, por sua vez, tornam necessário refletir, a fim de encontrar, em cada caso, o conteúdo e o sentido da dignidade da pessoa humana que se busca concretizar.

No caso do transexual, o debate é profundo, pois, de um lado, poder-se-ia caracterizar a cirurgia de redesignação de sexo como mutilante, o que afastaria a legalidade de sua realização; ${ }^{225}$ e, de outro, a licitude estaria justificada por se tratar da única forma de solucionar o problema do transexual, tratando-se de uma plástica corretiva e de uma "cura social". 226

Cumpre, então, assentar, como conclusão da reflexão desenvolvida nesses tópicos, a convicção de que a realização da cirurgia para a modificação da genitália não é condição para o diagnóstico da transexualidade, mas, sim, a última forma de tratamento a que se chega quando as demais não lograram resultado.

Nesse sentido, é expressa a lição de Elimar Szaniawski: “O fato de estar a pessoa perfeita e corretamente caracterizada como transexual não significa que a mesma deva, obrigatoriamente, ser submetida à cirurgia de mudança de sexo, que, segundo

\footnotetext{
${ }^{225}$ PERES, Ana Paula Ariston Barion. Transexualismo: o direito a uma nova identidade sexual. Rio de Janeiro: Renovar, p. 163.

${ }^{226}$ Idem, p. 164/165.
} 
nosso entender, é de um último e derradeiro recurso, utilizado somente depois da falência das demais terapias adequadas ao caso".227

É dizer, sob o ângulo dos direitos humanos, a identificação com o sexo oposto que caracteriza a transexualidade não necessariamente implica a efetiva transformação do órgão sexual. Tanto assim que a Resolução CFM nº 1955 , partindo da premissa de "ser o paciente transexual portador de desvio psicológico permanente de identidade sexual, com rejeição do fenótipo e tendência à automutilação e/ou autoextermínio" (segundo Considerando, da Resolução), alude à cirurgia como "a etapa mais importante do tratamento de pacientes" transexuais (quinto Considerando), bem marcando a diferença entre o diagnóstico e a forma de tratamento.

Acresce que a operação sequer consiste no único tratamento possível, como expresso na Portaria n. 457, da Secretaria de Atenção à Saúde do Ministério da Saúde, já referida no item 08.

De fato, admitem-se terapias medicamentosa, hormonal, psicopedagógica e psiquiátrica, que chegam a possibilitar que a pessoa viva como alguém do sexo oposto sem jamais se submeter à intervenção cirúrgica. ${ }^{228}$

Significa afirmar: a efetiva mudança da genitália não é necessária para que se considere a pessoa transexual, na consideração de que existem outras formas de transformação corporal aptas a aproximar a aparência do indivíduo ao seu sexo de identificação, situando-se a intervenção cirúrgica no plano do tratamento e não do diagnóstico.

Nessa quadra, a proposta de tutela dos transexuais a ser desenvolvida baseia-se em perspectiva jurídico-humanística, fora dos marcos patologizantes próprios da medicina, como proposto pela socióloga Berenice Bento, ${ }^{229}$ que há muito vem se dedicando ao estudo da transexualidade. Tal perspectiva caracteriza-se pela aproximação da transexualidade do campo do conflito de identidade e dos direitos humanos. $^{230}$

O distanciamento do discurso médico na reflexão sobre a situação jurídica do transexual é igualmente proposto por Roger Raupp Rios, para quem é necessário considerar a transexualidade também por uma abordagem social, ao lado da

\footnotetext{
${ }^{227}$ Limites e possibilidades do direito de redesignação do estado sexual. São Paulo: RT, 1999, p. 68.

228 SZANIAWSKI, Elimar. Limites e possibilidades do direito de redesignação do estado sexual. São Paulo: RT, 1999, p. 68, nota 72.

${ }^{229}$ A reinvenção do corpo: sexualidade e gênero na experiência transexual. Rio de Janeiro: Garamond, 2006, p. 69/70.

${ }^{230}$ BENTO, Berenice. O que é transexualidade? São Paulo: Editora Brasiliense, 2008, p. 113/114.
} 
médica. Segundo o autor, a interpretação constitucional sobre os direitos fundamentais dos transexuais pressupõe uma compreensão das relações sociais, a partir da noção de gênero, transcendente à discussão sobre o direito à intervenção cirúrgica que costuma dominar no debate sobre a transexualidade.

Alerta que a medicalização da discussão limita o tema pela perspectiva do binarismo de gênero, segundo o qual as identidades femininas e masculinas são definidas pelos profissionais da área da saúde, a partir de características genética, gonodal, endócrina, genital e psíquica, combinadas com as percepções socialmente dominantes sobre o que é ser masculino e feminino, de forma rígida e inflexível e, por isso, incompatível com um sistema jurídico protetivo dos direitos humanos.

Nas palavras do autor: "Se tal binarismo for adotado na compreensão das restrições de direitos experimentadas por transexuais, estar-se-á reforçando a rigidez e a determinação por terceiros (os detentores do saber médico e as crenças majoritárias sobre o que ser verdadeiramente feminino e masculino) acerca da identidade sexual e de gênero que cada indivíduo experimenta e desenvolve em sua vida; o que se estará enfraquecendo é o conteúdo jurídico de vários direitos fundamentais, dentre os quais destaco o princípio da igualdade", logo acrescentando: "De fato, eventual perspectiva da transexualidade que legitime a imposição de uma visão rígida e inflexível do fenômeno humano das relações entre os gêneros tem o impacto enorme em face de vários direitos fundamentais, para não dizer dramático". ${ }^{231}$

Nesse contexto, a garantia de reconhecimento da pessoa na sua diferença e a viabilização do exercício de direitos dentro de sua particularidade, quer parecer, deve ser buscada mais à luz da condição de transexual e menos em consequência da submissão à operação plástico-construtiva. Para tanto, popõe-se uma rotação no foco do estudo, da biologia para o direito, mantendo-se o alicerce da investigação no princípio da dignidade da pessoa humana.

Fixada a premissa, cabe aprofundar o estudo da transexualidade sob o ângulo jurídico, com base no direito internacional dos direitos humanos e no direito nacional brasileiro, propondo-se ao final uma reflexão sobre a tutela jurídica tanto do transexual operado quanto do não operado, o que será desenvolvido adiante, no último capítulo deste trabalho.

${ }^{231}$ RIOS, Roger Raupp. Direito da Antidiscriminação, Sexo, Sexualidade e Gênero: a Compreensão da Proibição Constitucional de Discriminação por Motivo de Sexo. In Sarmento, Daniel, Ikawa, Daniela e Piovesan, Flavia. Igualdade, Diferença e Direitos Humanos. Rio de Janeiro: Lúmen Juris, 2008, p. 707/708 e p. 708 . 


\section{III) FUNDAMENTOS JURÍDICOS PARA A PROTEÇÃO}

DOS TRANSEXUAIS

\section{Introdução}

A violação da dignidade da pessoa humana fica clara nos depoimentos de transexuais.

Luciana, operada em 2007, costureira, morava na Marambaia, subúrbio do Rio, em um casebre. Na escola, na Bahia, cada vez que ouvia seu nome masculino na chamada tinha "vontade de morrer" e não ia ao banco buscar o segurodesemprego para não se sentir humilhada: "Vão chamar aquele nome e vai aparecer outra coisa; prefiro não ir". ${ }^{232}$ Também não ia a posto de saúde: "Eu pago meus impostos, mas não me sinto uma cidadã. É um desamparo só". 233

Jô Bernardo, transexual portuguesa, por sua vez, acentua a disparidade das áreas do Direito e da Medicina no enfrentamento da questão: "É uma contradição. Exigem-nos que vivamos dois anos como mulheres e, depois, temos de manter o Boletim de Identidade como homens. Em termos cirúrgicos, são-nos dadas todas as possibilidades que nos são negadas em termos jurídicos. E, para qualquer lado que vá, tenho de apresentar o BI de uma pessoa que já não existe". 234

Os relatos dos transexuais revelam, assim, que a tutela de seus direitos envolve o tratamento do tema sob dois ângulos: uma primeira dimensão íntima e privada, ligada à liberdade e à autonomia para o livre desenvolvimento da personalidade, em cujo processo ocorrerá a identificação de gênero; e uma esfera pública, que pressupõe a igualdade de tratamento, o reconhecimento e o respeito a essa identidade pela coletividade, tratando-se de dimensão igualitária que corresponde à etapa de generalização dos direitos humanos. $^{235}$

A dicotomia entre as esferas pública e privada é explorada pela doutrina. Neste trabalho, releva trazer o ponto que as aproxima, qual seja a dignidade da pessoa humana, que é tutelada pelo direito internacional dos direitos humanos, pelo direito constitucional e pelos direitos da personalidade, nos âmbitos público e privado, respectivamente.

\footnotetext{
${ }^{232}$ Revista Piauí no 43, de abril 2010, p. 42.

${ }^{233}$ Revista Piauí no 43, de abril 2010, p. 42.

${ }^{234}$ Transexual espanhola em visita a Portugal para defender a lei de identidade. In DN Portugal on line, http://dn.sapo.pt/inicio/portugal/interior.aspx?content id=1450543, acesso em 03/01/2011.

${ }^{235}$ LAFER, Celso. A internacionalização dos direitos humanos. Barueri, SP: Manole, 2005, p. 37.
} 
Jorge Miranda, após identificar vários pontos de contato com base no postulado primordial da dignidade da pessoa humana, distingue os direitos fundamentais dos direitos da personalidade com base nos respectivos sentidos, projeções e perspectivas. Afirma que os direitos fundamentais estão assentados em relações de poder e têm incidência publicística; enquanto os direitos da personalidade pressupõem relações de igualdade e possuem incidência privatística, situando os direitos fundamentais no direito constitucional, e os direitos da personalidade no direito civil. ${ }^{236}$

Já para José de Oliveira Ascenção, o âmago da distinção entre direitos fundamentais e direitos da personalidade não se funda na natureza pública ou privada, mas na defesa absoluta da pessoa humana enquanto tal, objetivo central dos direitos da personalidade, apenas lateralmente perseguido pelos direitos fundamentais. ${ }^{237}$

Sob esse aspecto, cabe afirmar, com Cançado Trindade, que a importância da pessoa humana reconhecida pelas normas internacionais e nacionais enfraquece a rígida distinção entre direito público e direito privado, "que não resiste aos imperativos de proteção dos direitos humanos", ${ }^{238}$ em defesa dos ostensivamente mais fracos e vulneráveis, ou seja, das vítimas de violação de direitos humanos.

$\mathrm{O}$ art. $5^{\circ}, \S 2^{\circ}$, da Constituição Brasileira é exemplo de complementação entre os ordenamentos internacional e nacional, estabelecendo a “interação entre a ordem jurídica interna e a ordem jurídica internacional", 239 na implementação dos direitos humanos.

Concorrem, assim, o direito interno e o direito internacional para a proteção do ser humano, no resultado do processo de universalização, que para Cançado Trindade se explica pela crença, sedimentada na consciência coletiva, da dignidade inerente à pessoa humana. ${ }^{240}$ Nesse sentido, sustenta o autor que a fonte material principal do direito internacional dos direitos humanos é a "consciência jurídica universal", formando um ramo autônomo da ciência jurídica, com especificidade própria, voltada à

\footnotetext{
${ }^{236}$ MIRANDA, Jorge. Manual de Direito Constitucional. Tomo IV, cit., p. 69.

${ }^{237}$ Pessoa, Direitos Fundamentais e Direitos da Personalidade. In Estudos de Direito da Bioética, vol III, p. 51/75. Coimbra: Almedina, 2009, p. 54/55.

${ }^{238}$ CANÇADO TRINDADE, Antônio Augusto. Tratado Internacional de Direitos Humanos. Volume I. $2^{\mathrm{a}}$ ed. Porto Alegre: Sergio Fabris, 2003, p. 42.

${ }^{239}$ PIOVESAN, Flavia. Direitos Humanos e Direito Constitucional Internacional. $5^{\text {a }}$ ed. São Paulo: Max Limonad, 2002, p. 65.

${ }^{240}$ CANÇADO TRINDADE, Antônio Augusto. Tratado Internacional de Direitos Humanos, cit., p. 37.
} 
tutela dos seres humanos nos planos nacional e internacional, em toda e qualquer circunstância. $^{241}$

Exemplo dessa especificidade é a natureza não multilateral dos tratados de direitos humanos, que cria regime objetivo, de normas convergentes e representativas de interesses coletivos dos Estados (proteção dos direitos humanos, em benefício do indivíduo), contraposto ao regime de reciprocidade, caracterizado pelas vantagens mútuas aos Estados contratantes. ${ }^{242}$

A internacionalização dos direitos humanos e a assimilação das normas internacionais pelos Estados também encontram fundamento na preocupação dos governantes em legitimar seus governos no plano mundial, ${ }^{243}$ o que torna o tema dos direitos humanos, entendidos como "um conjunto mínimo de direitos necessários para assegurar uma vida do ser humano baseada na liberdade e na dignidade", 244 "um elemento de diálogo entre os povos". 245

Podem-se, então, apontar três níveis de proteção que contribuem para tornar concreta a dignidade dos transexuais: o plano do direito internacional dos direitos humanos, com base nas Declarações e Resoluções; o plano do direito constitucional, especialmente no que se refere à liberdade, à igualdade e à intimidade; e o plano do direito civil e dos direitos da personalidade, relativamente ao corpo, ao nome, ao estado e à vida privada.

Dada a interpenetração das normas protetivas dos direitos humanos no ordenamento interno, os conteúdos dos relevantes direitos à liberdade e à igualdade e respectivos desdobramentos serão analisados a partir do direito nacional, optando-se por limitar o objeto do estudo do direito internacional dos direitos humanos à proteção da identidade de gênero que caracteriza a transexualidade.

Assim, a partir do sistema protetivo dos direitos humanos, voltado ao combate da violência e discriminação por identidade de gênero, e das normas nacionais e internacionais relativas à tutela da pessoa e suas projeções, pretende-se extrair fundamentos para o reconhecimento do direito à identidade de gênero ou sexual, como atributo inerente à personalidade, imanente da eficácia irradiante dos direitos humanos.

241 CANÇADO TRINDADE, Antônio Augusto. Tratado Internacional de Direitos Humanos, cit., p. $38 / 39$.

${ }^{242}$ RAMOS, Andre de Carvalho. Processo Internacional de Direitos Humanos. Rio de Janeiro: Renovar, 2002 , p. $28 / 29$.

${ }^{243}$ LAFER, Celso. Prefácio ao livro: LINDGREN ALVES. Os direitos humanos como tema global. São Paulo: Perspectiva, 1994, XXIV.

${ }^{244}$ RAMOS, Andre de Carvalho. Direitos Humanos em Juízo. Max Limonad, 2001, p. 27.

${ }^{245}$ RAMOS, Andre de Carvalho. Processo Internacional de Direitos Humanos, cit., p. 18. 


\section{A) O DIREITO INTERNACIONAL DOS DIREITOS}

\section{HUMANOS}

\section{1) Nota introdutória}

A proteção internacional dos direitos humanos conta com um sistema global, no âmbito da Organização das Nações Unidas (ONU), e com sistemas regionais, cujo estudo, em razão do foco dado ao tema, limitar-se-á ao Sistema Europeu e ao Sistema Interamericano.

A doutrina identifica duas grandes fases na história do Direito Internacional dos Direitos Humanos: a legislativa e a de implementação. ${ }^{246}$ Em relação aos transexuais, subsiste tanto a necessidade de elaboração de normas de proteção, quanto sua respectiva concretização.

O estágio de desenvolvimento atual do DIDH, como se verá, consiste principalmente na atuação da Comissão de Direitos Humanos, da Organização das Nações Unidas (ONU), e da Comissão Interamericana de Direitos Humanos, da Organização dos Estados Americanos (OEA), diante das denúncias de violência e discriminação contra transexuais ao redor do mundo.

No continente europeu, talvez onde mais se tenha avançado na regulamentação dos efeitos jurídicos da transexualidade, verifica-se uma atuação judicial específica, na salvaguarda do direito à identidade de gênero do transexual. Por razões metodológicas, a ação da Corte será analisada em apartado, no Capítulo V.

\section{2) O combate à violência e discriminação por identidade de}

gênero

A identidade de gênero do transexual, como um bem protegido autonomamente em relação à orientação sexual, é reconhecida no sistema internacional dos direitos humanos.

Em 2007, um grupo de especialistas em legislação internacional de direitos humanos e em orientação sexual e identidade de gênero promoveu a publicação dos Princípios de Yogyakarta, sobre a aplicação da legislação internacional de direitos humanos em relação à orientação sexual e à identidade de gênero. Embora não aprovados com força de norma, tais princípios acabaram incorporados pela comunidade internacional

\footnotetext{
${ }^{246}$ ALMEIDA, Guilherme Assis de. Direitos humanos e não-violência. São Paulo: Atlas, 2001, p. 63.
} 
e utilizados como orientação por Estados membros, na fixação de suas políticas internas. Como lembrou o Comissário de Direitos Humanos do Conselho da Europa, em 2009, Thomas Hammarberg, os Princípios de Yogyakarta foram endossados e considerados importante ferramenta para indentificar a obrigação dos Estados de respeitar, proteger e efetivar os direitos humanos de todos, independentemente de sua identidade de gênero. ${ }^{247}$

Os Princípios de Yogyakarta são expressos ao incluir o direito à identidade de gênero entre os direitos humanos, estabelecendo, logo no primeiro princípio: "Todos os seres humanos nascem livres e iguais em dignidade e direitos. Os seres humanos de todas as orientações sexuais e identidades de gênero têm direito ao pleno desfrute de todos os direitos humanos" (tradução livre). ${ }^{248}$ Vedam a discriminação por orientação sexual ou identidade de gênero, no princípio seguinte, sobre os direitos à igualdade e a não discriminação. ${ }^{249}$

Em 18 de dezembro de 2008, nas comemorações dos 60 anos da Declaração Universal dos Direitos Humanos, a Assembleia Geral da Organização das Nações Unidas demonstrou preocupação com a violência e a discriminação por identidade de gênero, aprovando declaração conjunta de sessenta e seis países, pela qual foi reafirmado o princípio de não discriminação por orientação sexual ou identidade de gênero, e manifestada profunda preocupação com as violações de direitos humanos e liberdades fundamentais, além da violência, discriminação, perseguição, exclusão e estigmatização em razão da orientação sexual ou identidade de gênero. ${ }^{250}$

Em 22/03/2011 nova Declaração foi apresentada perante o Conselho de Direitos Humanos da ONU, em Genebra. Denominada “Declaração conjunta

247 HAMMARBERG, Thomas. Human Rights and gender identity. Estrasburgo, 29/07/2009. CommDH/IssuePaper(2009), II. International Human Rights Law. Disponível em: <wcd.coe.int/ViewDoc.jsp?id=1476365>, último acesso em 02/02/2012.

${ }^{248}$ Principio 1. El derecho al disfrute universal de los derechos humanos: "Todos los seres humanos nacen libres e iguales en dignidad y derechos. Los seres humanos de todas las orientaciones sexuales e identidades de género tienen derecho al pleno disfrute de todos los derechos humanos". In Introducción a los princípios de yogyakarta, p. 10. Disponível em:www.yogyakartaprinciples.org/principles_sp.pdf, último acesso em 02/01/2012.

${ }^{249}$ Principio 2. Los derechos a la igualdad y a la no discriminación: "Todas las personas tienen derecho al disfrute de todos los derechos humanos, sin discriminación por motivos de orientación sexual o identidad de género. Todas las personas tienen derecho a ser iguales ante la ley y tienen derecho a igual protección por parte de la ley, sin ninguna de las discriminationes mencionadas, ya sea que el disfrute de otro derecho humano también esté afectado o no. La ley prohibirá toda discriminación de esta clase y garantizará a todas las personas protección igual y efectiva contra cualquier forma de discriminación de esta clase”. In $\begin{array}{lllllll}\text { Introducción } & a & \text { los } & \text { princípios de yogyakarta, } & \text { p. } & 10 . & \text { Disponível }\end{array}$ em:www.yogyakartaprinciples.org/principles_sp.pdf, último acesso em 02/01/2012. $250 \quad 70^{\mathrm{a}}$ e $71^{\mathrm{a}}$ Sessões Plenárias - sessão da manhã. Disponível in <old.ilga.org/print.asp?LanguageID=5\&FileID=1215\&FileCategory=32\&ZoneID=28\&>， acesso em $14 / 11 / 2011$. 
para fazer cessarem os atos de violência e as violações de direitos humanos a eles relacionadas, dirigidos contra as pessoas por conta de sua orientação sexual ou identidade de gênero" (tradução livre), ${ }^{251}$ a Declaração assemelha-se àquela apresentada na Noruega em 2006, com a diferença de que esta contou com oitenta e cinco assinaturas de EstadosParte, e aquela com cinquenta e quatro, indicando uma maior adesão e um importante apoio das nações asiáticas e africanas. ${ }^{252}$

Em 15 de junho de 2011, o Conselho de Direitos Humanos das Nações Unidas aprovou Resolução A/HRC/17/L.9/Rev.1, sobre direitos humanos, orientação sexual e identidade de gênero.

Expressando forte preocupação com a violência e discriminação, solicitou que o Alto Comissário encomendasse um estudo a ser concluído até dezembro de 2011, para o levantamento da violência por identidade de gênero em todas as regiões do globo e para documentar como a legislação internacional de direitos humanos pode ser utilizada para combatê-la. Resolveu, ainda, convocar um painel de discussão sobre o referido estudo, propondo um diálogo construtivo, informado e transparente, sobre as leis e práticas discriminatórias detectadas, a ser realizado durante a $19^{a}$ Sessão do Conselho de Direitos Humanos, prevista para ocorrer entre 27 de fevereiro e 23 de março, de 2012, decidindo "acompanhar de forma contínua esta questão prioritária". ${ }^{253}$

No sistema regional interamericano, foi aprovada a Resolução sobre "Direitos Humanos, Orientação Sexual e Identidade de Gênero", pela $38^{\mathrm{a}}$ Assembleia Geral da OEA (AG/Res. nº 2435 (XXXVIII-O/08)), seguida pelas Resoluções $n^{\circ} 2504$ (XXXIX-O/09) e no 2600 (XL-O/10), visualizando-se, na alusão em separado da identidade de gênero, um reconhecimento do respectivo direito que se busca assegurar ao transexual.

A violência a que expostos os transexuais, transgêneros e travestis no Brasil foi denunciada em audiência perante a Comissão Interamericana de

\footnotetext{
251 "Declaración conjunta para poner alto a los actos de violencia, y a las violaciones de derechos humanos relacionadas, dirigidos contra las personas por su orientación sexual e identidad de género"

${ }^{252}$ SALUM, Alejandro Nasif. Histórica declaración sobre diversidad sexual en el Consejo de Derechos Humanos de la ONU. Disponível em: www.lgbt.org.ar/00,diversidad-02.php, acesso em 31/08/2011.

${ }^{253}$ UN Resolution on Sexual Orientation and Gender Identity. "The Human Right Council (...) 4. Decides to remain seized of this priority issue”. Texto da Resolução disponível em:www.scribd.com/mobile/documents/58106434/download?secret_password=5zggsd608turz0rct68, último acesso em 04/01/2012.
} 
Direitos Humanos, em seu $140^{\circ}$ período de Sessões, realizada no dia 25 de outubro de 2010, sob o título "Discriminação contra transexuais, transgêneros e travestis no Brasil". 254

$\mathrm{O}$ tema continuou em pauta no âmbito regional. Em 25 de março de 2011 , no $141^{\circ}$ período de audiências da mesma Comissão, a audiência realizada no Salão Rubén Darío versou sobre os direitos humanos, a orientação sexual e a identidade de gênero no Haiti. ${ }^{255}$

Atualmente, a Resolução da OEA em vigor, nº 2653 (XLIO/11), aprovada pela Assembleia Geral na quarta sessão plenária realizada em 07/06/2011, além de afirmar a autonomia da identidade de gênero entre as demais formas de discriminação e condenar a violência e discriminação, instou os Estados a adotarem as medidas necessárias para prevenir, sancionar e erradicar a discriminação, de acordo com os parâmetros jurídicos de seus ordenamentos internos.

Solicitou à Comissão Interamericana de Direitos Humanos e ao Comitê Jurídico Interamericano estudos sobre as implicações jurídicas e desenvolvimentos conceituais e terminológicos relativos à orientação sexual, identidade de gênero e expressão de gênero. Determinou que a Comissão de Assuntos Jurídicos e Políticos “inclua em sua agenda a consideração do resultado dos estudos solicitados, com a participação da sociedade civil interessada, antes do Quadragésimo Segundo Período Ordinário de Sessões da Assembleia Geral" (item 6, da Resolução OEA n. 2653). ${ }^{256}$

A tendência que se verifica na ONU e na OEA, quanto à necessidade de regulamentação dos efeitos jurídicos da transexualidade, segue orientação do Conselho da Europa, cuja Assembleia Parlamentar, em 1.989, adotou a Recomendação $n^{\circ}$ 1117, exortando o Comitê de Ministros a expedir uma Recomendação, aconselhando os Estados Membros a legislarem adequadamente para as comunidades transexuais de seus países (item 11, da Resolução 1117). ${ }^{257}$ Tal Recomendação veio acompanhada do Anexo II, denominado "Resolução sobre a discriminação contra transexuais", tendo o Parlamento

\footnotetext{
${ }^{254}$ Audiência realizada no dia 25 de outubro de 2010, 11:15-12:15 horas, Salón Padilha Vidal (Nível TL del GSB). Disponível em: www.cidh.org/Comunicados/Spanish/2010/calendario140sp.htm, último acesso em $1 \% 01 / 2012$.

${ }_{255}^{255}$ Audiência realizada entre 10:15 - 11:00 horas. Disponível em:<cidh.org/Comunicados/Spanish/2011/CALENDARIO141SP.htm>, último acesso em 01/01/2012.

${ }^{256}$ Íntegra da Resolução disponível em: www.oas.org/consejo/sp/AG/Documentos/AG05485P05.doc, último acesso em 1\%01/2012.

${ }^{257}$ Íntegra da Resolução 1117, de 1989 disponível em:www.looking-glass.greenend.org.uk/rec1117.htm, último acesso em 01/01/2012.
} 
Europeu, há quase quinze anos, estabelecido que a dignidade humana e os direitos individuais devem incluir o direito de viver de acordo com a identidade sexual. ${ }^{258}$

A preocupação dos órgãos internacionais com a violência e discriminação por identidade de gênero aponta para uma preocupação com o indivíduo, em contraposição à sociedade, o que não se confunde com a concepção liberal clássica do individualismo, uma vez que tal retorno apenas implica reconhecer a pessoa em sua singularidade e não mais como categoria abstrata. 259

Nesse contexto, as Resoluções recentemente aprovadas sinalizam uma maior visibilidade da população transexual e, ainda que limitadas a externar preocupação com a violência e discriminação, não deixam de sinalizar uma tendência à especificação, consistente "na passagem gradual, porém cada vez mais acentuada, para uma ulterior determinação dos sujeitos titulares de direitos", 260 como se percebe estar ocorrendo em relação à pessoa transexual.

\section{3) Relevância da Resolução $n^{0}$ 17/L.9/Rev.1, da ONU e da}

\section{Resolução no 2653 (XLI-O/11), da OEA}

A par da importância que se admite a todos os planos normativos, especial importância deve ser reconhecida ao direito internacional dos direitos humanos para conduzir mudanças sociais, dada sua natureza consensual e tendência para a universalização. Sob esse enfoque, o direito internacional dos direitos humanos atua como vetor orientador da ação do Estado, a balizar suas condutas no plano interno. ${ }^{261}$

Trata-se de domínio em que a função promocional do direito, identificada por Bobbio e sintetizada por Lafer como "um Direito que, no mundo contemporâneo, não se circunscreve ao comandar, ao proibir e ao permitir condutas, mas que transita pelo estimular e pelo desestimular comportamentos", ${ }^{262}$ reveste-se de especial relevância.

258 Appendix II. Resolution on discrimination against transsexuals. "The European Parliament, (...)1.Believes that human dignity and personal rights must include the right to live according to one's sexual identity”. Disponível em:www.looking-glass.greenend.org.uk/rec1117.htm, último acesso em 01/01/2012

${ }^{259}$ SALES, Dimitri Nascimento. Direito à visibilidade: direito humano da população GLBTT. In Direitos humanos: fundamento, proteção e implementação, p. 932.

${ }^{260}$ BOBBIO, Norberto. A era dos direitos. In A era dos direitos. Tradução de Carlos Nelson Coutinho. Apresentação de Celso Lafer. Rio de Janeiro: Elsevier, 2004, p. 78.

${ }^{261}$ AMARAL JUNIOR, Alberto do. JUBILUT, Liliana Lyra. O Direito Internacional dos Direitos Humanos e o Supremo Tribunal Federal. In AMARAL JUNIOR, Alberto do. JUBILUT, Liliana Lyra (orgs). O STF e o Direito Internacional dos Direitos Humanos. São Paulo: Quartier Latin, 2009, p. 30.

${ }^{262}$ LAFER, Celso. A internacionalização dos direitos humanos, cit., p. 129. 
Uma contribuição percebida em relação ao papel das Resoluções para a concretização dos direitos humanos dos transexuais, vítimas de violência e discriminação, consiste no estímulo à tolerância.

Como aponta Bobbio, uma razão moral a favor da tolerância é o princípio aboluto de que devemos respeito à pessoa alheia, tratando-se de um dever ético, ${ }^{263}$ que comporta diminuta restrição. De fato, analisa o autor que a imposição de limites lícitos à tolerância não é algo simples, sintetizando: “O único critério razoável é o que deriva da ideia mesma de tolerância, e pode ser formulado assim: a tolerância deve ser estendida a todos, salvo àqueles que negam o princípio da tolerância, ou, mais brevemente, todos devem ser tolerados, salvo os intolerantes". ${ }^{264}$

Além dessa perspetiva ética, Celso Lafer ressalta a importância da tolerância como valor inspirador da democracia. Nas palavras do professor: "a democracia parte do pressuposto de que a convivência coletiva requer a civilidade do princípio da reciprocidade - o do ut des - da tolerância mútua - pois se me atribuo o direito de impor e perseguir, concedo ao outro este mesmo direito". 265

Nessa esteira, as Recomendações dos órgãos internacionais, externando preocupação com a violência e discriminação contra transexuais, propagam o valor da tolerância no plano internacional. Assim, apontam para a obrigação de respeito para com aqueles que ostentam uma identidade de gênero contraditória, ao mesmo tempo quereafirmam a democracia como regime político favorável à proteção dos direitos humanos.

Outra consequência pode ser assinalada.

As Recomendações das Comissões de Direitos Humanos, tanto da ONU quanto da OEA, determinam que se proceda a estudos e levantamentos, não só sobre os números da violência, mas também sobre as consequências jurídicas da transexualidade. Desse modo, acabam por estimular a busca por mecanismos jurídicos de proteção, entre os quais emergem os direitos da personalidade, tratando-se de ramo típico do ordenamento jurídico interno.

O delineamento do direito à identidade sexual, assim, ao admitir a identificação civil de acordo com a aparência sinaliza o respeito à pessoa, pelas

\footnotetext{
${ }^{263}$ As razões da tolerância. In A era dos direitos. Tradução de Carlos Nelson Coutinho. Apresentação de Celso Lafer. Rio de Janeiro: Elsevier, 2004, p. 211/212.

${ }^{264}$ Idem, p. 216.

${ }^{265}$ O liberalismo de inovação e a política da cultura. In Desafios: ética e política. São Paulo: Siciliano, 1995, p. 39.
} 
instituições jurídicas de seu País, preservando o indivíduo da exposição vexatória que acirra sua vulnerabilidade.

Trata-se do oferecimento de uma resposta, a qual, ao possibilitar a alteração do nome e sexo no registro civil, consiste em forma de inclusão auxiliar no combate à violência e discriminação, dado o papel simbólico do direito.

Como anota Julieta Lemaitre Ripoll, professora da Faculdade de Direito da Universidade de Bogotá e diretora do Centro de Pesquisas Sociojurídicas da mesma Universidade: "o direito é uma forma poderosa de criar significados sociais profundamente morais, e o apelo LGBT ao direito também está marcado pelo desejo desses significados morais inclusivos de sua identidade". ${ }^{266}$

Acrescenta a professora a importância do efeito simbólico do direito: "é um antídoto poderoso contra a percepção de si mesmo e da vida social que a experiência de discriminação oferece e talvez seja também uma espécie de antídoto ou conjuro contra as sequelas emocionais da violência - um "contra" que se baseia na possibilidade de resistir ao poder interpretativo da violência usando para isso a força simbólica do direito". ${ }^{267}$

Nessa esteira, eventual solução jurídica nacional que contribua para melhorar a situação dos transexuais como vítimas de exclusão pode produzir efeitos na esfera internacional.

Trata-se da relação de complementaridade existente entre os sistemas internacional e interno, cabendo a este a responsabilidade primária e àquele uma atuação complementar, resultando no sistema de salvaguarda dos direitos humanos. Em razão dessa relação dialética, as transformações em uma esfera repercutem diretamente na outra, ${ }^{268}$ podendo-se aventar melhoras no plano internacional a partir de experiências bem sucedidas em determinados países.

Daí a importância das Resoluções dos órgãos internacionais, externando preocupação com a violência e a discriminação contra transexuais e exortando

\footnotetext{
${ }^{266}$ RIPOLL, Julieta Lemaitre. O amor em tempos de cólera: direitos LGBT na Colômbia. Tradução de Pedro Maia Soares. In SUR - Revista Internacional de Direitos Humanos, cit., p. 88.

${ }^{267}$ Idem, página, p. 89.

${ }^{268}$ AMARAL JUNIOR, Alberto do. JUBILUT, Liliana Lyra. O Direito Internacional dos Direitos Humanos e o Supremo Tribunal Federal. In AMARAL JUNIOR, Alberto do. JUBILUT, Liliana Lyra (orgs). O STF e o

Direito Internacional dos Direitos Humanos, cit., p. 32.
} 
a pesquisa jurídica em busca de alternativas de proteção, na perspectiva de que não basta justificar os direitos do homem, importando, sim, tornar efetiva sua proteção. ${ }^{269}$

Para tanto, além do plano do direito internacional dos direitos humanos, a concretização dos direitos das pessoas transexuais também encontra fundamentos nos princípios da liberdade e da igualdade, que em seguida serão aprofundados.

\section{B) LIBERDADE}

\section{1) A liberdade como direito humano fundamental}

A liberdade, para aqueles que aceitam um direito superior e anterior ao direito positivo e admitem a existência do direito natural, é o mais alto na hierarquia dos direitos fundamentais, tratando-se da principal característica da espécie humana, cuja nota distintiva é a capacidade de autodeterminação consciente da própria vontade. $^{270}$

Nesse sentido, a lição de Adriano De Cupis, para quem "o direito à liberdade é considerado como um direito que, além de essencial, é inato, no sentido de que para sua existência é suficiente o pressuposto da personalidade". ${ }^{271}$

Na definição do art. $4^{\circ}$, da Declaração Francesa de Direitos do Homem e do Cidadão, de 1789: “A liberdade consiste em fazer tudo o que não prejudique o próximo: assim, o exercício dos direitos naturais de cada homem não tem por limites senão aqueles que asseguram aos outros membros da sociedade o gozo dos mesmos direitos. Estes limites apenas podem ser determinados pela lei". ${ }^{272}$ Como pontua Fernando Dias Menezes de Almeida, trata-se do estabelecimento de limites ao exercício das liberdades por dois ou mais titulares, diante de determinadas circunstâncias em que haja colisão. $^{273}$

$\mathrm{O}$ art. $5^{\circ}$, da Declaração de 1789 , cuida de outro aspecto da tutela da liberdade, somente passível de limitações decorrentes da lei: “A lei não proíbe

\footnotetext{
${ }^{269}$ BOBBIO, Norberto. Sobre os fundamentos dos direitos do homem. In A era dos direitos. Tradução de Carlos Nelson Coutinho. Apresentação de Celso Lafer. Rio de Janeiro: Elsevier, 2004, p. 43.

270 FERREIRA FILHO, Manoel Gonçalves. Parecer: Questões constitucionais e legais referentes a tratamento médico sem transfusão de sangue, p. 20.

${ }^{271}$ DE CUPIS, Adriano. $O$ direito à liberdade. In Os direitos da personalidade. Tradução de Adriano Vera Jardim e António Miguel Caeiro. Lisboa: Livraria Morais Editora, 1961, p. 107.

${ }^{272}$ Tradução de Manuel Gonçalves Ferreira Filho, Direitos Humanos Fundamentais, Saraiva, 2004, 6ª ed., p. 168.

${ }^{273}$ Liberdade de reunião, Max Limonad, 2001, p. 22 e segs.
} 
senão as ações nocivas à sociedade. Tudo que não é vedado pela lei não pode ser obstado e ninguém pode ser constrangido a fazer o que ela não ordena". ${ }^{274}$ Trata-se da liberdade dos indivíduos em relação ao poder do Estado. ${ }^{275}$

A liberdade foi mantida em destaque na Declaração Universal dos Direitos Humanos, de 1948, cujos artigos I e III estabelecem, respectivamente: “Todas as pessoas nascem livres e iguais em dignidade e direitos. São dotadas de razão e consciência e devem agir em relação umas às outras com espírito de fraternidade"; e "Toda pessoa tem direito à vida, à liberdade e à segurança pessoal", ${ }^{276}$

\section{2) Liberdade antiga e moderna. Liberdade positiva e} negativa. Liberdade na esfera pública e na esfera privada.

A definição de liberdade não é algo simples, embora se reconheça que sempre expressa um valor positivo.

Da liberdade natural de John Locke até hoje, prosseguiram investigações sobre o conceito de liberdade pela filosofia jurídica, política e moral, sem que se tenha alcançado um significado único. Como anota Robert Alexy, "o conceito de liberdade é, ao mesmo tempo, um dos conceitos práticos mais fundamentais e menos claros", 277 cujo âmbito de aplicação parece quase ilimitado, à vista da conotação positiva que induz. Por isso, denominar algo como "livre" ou associar determinada conduta à "liberdade", "suscita, no ouvinte, um estímulo para compartilhar desse valor". 278

Assumida a premissa quanto à dificuldade de definição, resta averiguar os sentidos da liberdade identificados pela doutrina especializada.

Benjamin Constant é indicado como o autor que indicou "com uma precisão até então desconhecida a diferença entre os dois modos distintos de se entender a liberdade na linguagem política", ${ }^{279}$ denominados a liberdade dos modernos, como gozo privado, e a liberdade dos antigos, como participação no poder político.

\footnotetext{
${ }^{274}$ Tradução de Manuel Gonçalves Ferreira Filho, Direitos Humanos Fundamentais, Saraiva, 2004, $6^{\mathrm{a}}$ ed., p. 168.

${ }^{275}$ BOBBIO, Norberto. A herança da grande revolução. In A era dos direitos, cit., p. 122.

${ }^{276}$ Código de Direito Internacional de Direitos Humanos anotado. Coord. Geral Flávia Piovesan. São Paulo: DPJ, 2008, p. 16.

${ }^{277}$ ALEXY, Robert. Teoria dos Direitos Fundamentais. Tradução de Virgílio Afonso da Silva. São Paulo: Malheiros Editores, 2008, p. 218.

${ }^{278}$ Idem, mesma página.

${ }^{279}$ BOBBIO, Norberto. Kant e as duas liberdades. In Teoria Geral da Política:a filosofia política e as lições dos clássicos. Org Michelangelo Bovero. Tradução de Daniela Beccaccia Versiani. Rio de Janeiro: Elsevier, 2000, p. 105.
} 
A partir dos conceitos de liberdade antigo e moderno de Benjamin Constant, Celso Lafer anota: "a liberdade antiga significa distribuição democrática do poder entre os cidadãos que participam da feitura das leis, em virtude do acatamento, pela comunidade política, dos princípios de isonomia e isegoria que asseguram aos seus membros igualdade na elaboração e aplicação das normas". 280

Nesse sentido, a liberdade antiga é a liberdade participativa do cidadão e não do homem em sua esfera privada e pressupõe uma comunidade política de pessoas em interação, consistindo na ativa liberdade de participação na polis, associada à ideia de participação política e de democracia. Aponta o professor Lafer que, em que pese o caráter público da liberdade antiga, vislumbra-se, ao mesmo tempo, uma dimensão existencial, na medida em que se traduz "num não a toda tentativa de subordinação do indivíduo e num sim a todo esforço de colaboração e de diálogo, na auto-revelação intersubjetiva do ser nas deliberações da comunidade política". ${ }^{281}$

A liberdade moderna, diversamente, pertence à esfera do privado e é entendida como um não-impedimento. Trata-se de uma "faculdade potestativa”, permitindo ao indivíduo optar entre o exercício e o não exercício de um direito. $^{282}$

Isaiah Berlin, partindo dos conceitos de Benjamin Constant, acrescentou aos conceitos de liberdade antiga e moderna as noções de liberdade positiva e negativa. Afirma que, enquanto a primeira se volta à indagação "por quem sou governado"; a segunda ideia de liberdade, a negativa, relaciona-se à resposta à pergunta "o quanto sou governado?". 283

Sob o enfoque da filosofia política, Norberto Bobbio identifica dois modos de compreender a liberdade, ora como não-impedimento, identificada à perspectiva liberal de liberdade; ora como autonomia, no sentido do poder de obedecer às próprias leis, vigente na doutrina democrática. Atribui a Monstesquieu a definição da liberdade própria da doutrina liberal, estabelecendo limites ao poder estatal, e a Rousseau o

\footnotetext{
${ }^{280}$ LAFER, Celso. O moderno e o antigo conceito de liberdade. In Ensaios Sobre a Liberdade. São Paulo: Editora Perspectiva, 1980, p. 12.

${ }^{281}$ Idem, p. 16.

${ }^{282}$ Idem, p. 18/19.

283 BERLIN, Isaiah. Dois conceitos de liberdade, in Quatro Ensaios sobre a liberdade. Brasília: Editora UNB, 1981, p. 133 e segs.
} 
sentido de liberdade na democracia, pela qual a liberdade corresponde não à autodeterminação individual, mas à autodeterminação coletiva. ${ }^{284}$

Do ponto de vista da teoria geral do Direito, do mesmo modo constata Bobbio diferenças de significados atribuídos à liberdade: uma primeira acepção, pela qual a liberdade se identifica com aquilo que é ao mesmo tempo permitido e não obrigatório, assemelhada à esfera da licitude; e uma segunda acepção, relacionada à liberdade como aquilo que é obrigatório por força de uma obrigação autoimposta e que, nesse sentido, oposta à coerção. ${ }^{285}$

A perspectiva liberal de liberdade é sintetizada por Aron como a ausência de coerção, ${ }^{286}$ assemelhada à liberdade como não-impedimento, em sentido negativo: "sou livre de fazer isto ou aquilo, de escolher minha conduta, se os outros não me obrigam, coagem ou impedem com a ameaça de sanções". ${ }^{287}$

Por derradeiro, cumpre trazer as definições de Robert Alexy. Afirma o autor que a base da liberdade jurídica consiste em uma relação triádica, entre um titular de uma liberdade (ou de uma não-liberdade), um obstáculo à liberdade e um objeto da liberdade. ${ }^{288}$ Acrescenta que, se o objeto da liberdade for uma ação, está-se diante do conceito positivo de liberdade, encontrado em Spinoza, Kant e Hegel, em relação ao qual os obstáculos à liberdade correspondem às ideias pouco claras, às emoções, impulsos sensoriais ou consciência equivocada, ${ }^{289}$ que dificultariam a ação do sujeito. Por outro lado, se o objeto da liberdade for uma alternativa de ação, estar-se-á diante da liberdade negativa, referida à liberdade jurídica, assim definida: "Uma pessoa é livre em sentido negativo na medida em que a ela não são vedadas alternativas de ação". 290

De todo modo, em que pese a distinção doutrinária entre a liberdade positiva e a negativa, certo é que não se trata de excludentes, mas, sim, de ângulos diversos e complementares do mesmo direito. Nesse sentido, o exemplo de Celso Lafer, referindo-se ao direito à informação previsto na Declaração Universal dos Direitos

\footnotetext{
${ }^{284}$ BOBBIO, Norberto. Kant e as duas liberdades. In Teoria Geral da Política:a filosofia política e as lições dos clássicos, cit., p. 103/104.

${ }^{285}$ BOBBIO, Norberto. Da liberdade dos modernos comparada à dos pósteros, In Teoria Geral da Política:a filosofia política e as lições dos clássicos, cit., p. 279.

${ }^{286}$ ARON, Raymond. A definição liberal da liberdade. In Estudos políticos. Tradução de Sergio Bath. Brasília: Universidade de Brasília, 1985, p. 226.

287 ARON, Raymond. Liberdade: liberal ou libertária. In Estudos políticos. Tradução de Sergio Bath. Brasília: Universidade de Brasília, 1985, p. 265.

${ }^{288}$ ALEXY, Robert. Teoria dos Direitos Fundamentais. Tradução de Virgílio Afonso da Silva. São Paulo:

Malheiros Editores, 2008, p. 220.

${ }^{289}$ Idem, p. 220/221.

${ }^{290}$ Idem, p. 222.
} 
do Homem. Segundo o professor, o direito está ligado à liberdade de opinião e de expressão, envolvendo tanto a liberdade negativa, de não ser molestado por conta da opinião expressada, quanto uma liberdade positiva, de exteriorizar publicamente as próprias ideias. $^{291}$

A possibilidade de identificar uma unidade essencial, ou um núcleo comum, nos diversos conceitos de liberdade, faz-se presente nas lições de Bobbio. Afirma o autor, após constatar a diferença dos dois usos do termo "liberdade" nas linguagens jurídica e política, que ambos podem ser reconduzidos a um significado comum: o de autodeterminação. ${ }^{292}$ Nesse sentido, para a teoria liberal, a liberdade dirige-se a ampliar a esfera de autodeterminação individual, restringindo ao máximo o poder coletivo, enquanto a teoria democrática tende a ampliar a esfera da autodeterminação coletiva, na valorização da liberdade como autonomia, ou como poder de ditar as próprias leis. ${ }^{293}$ Tal distinção explica-se pelo fato de que a doutrina liberal considera o problema da liberdade sob o ponto de vista do indivíduo isolado, considerado como um todo em si mesmo, e a doutrina democrática analisa a liberdade sob a perspectiva do indivíduo como partícipe de uma coletividade, considerado como parte de um todo. ${ }^{294}$ Nesse contexto, o sentido liberal da liberdade expressa uma exigência permanente, cujo valor normativo não deve ser desprezado, de luta contra os abusos do poder, ${ }^{295}$ mostrando-se vã a discussão sobre qual das duas liberdades seria a melhor. ${ }^{296}$

O direito de autodeterminação, nesses termos, constitui o núcleo comum presente nos diversos sentidos de liberdade, estendendo-se inclusive aos Estados. Como anota Andrew Hurrell, é a autodeterminação nacional que confere poder político e significado moral à ideia de sociedade internacional. ${ }^{297}$

Possui um âmbito negativo, de exigência de abstenção do Estado naquilo que somente diz respeito ao indivíduo em proteção à intimidade; e um aspecto positivo, manifestado pela possibilidade de agir, participar e ditar as próprias leis. Sob tal aspecto positivo, o direito de autodeterminação, ao que parece, refere-se tanto à

\footnotetext{
${ }^{291}$ A reconstrução dos direitos humanos, p. 242.

${ }^{292}$ BOBBIO, Norberto. Kant e as duas liberdades. In Teoria Geral da Política:a filosofia política e as lições dos clássicos, cit., p. 102.

${ }^{293}$ Idem, p. 102/103.

${ }^{294}$ Idem, p. 103.

${ }^{295}$ BOBBIO, Norberto. Da liberdade dos modernos comparada à dos pósteros, In Teoria Geral da Política:a filosofia política e as lições dos clássicos, cit., p. 278.

${ }^{296}$ Idem, p. 280.

297 Nationalism and the politics of identity.On global order. Power, Values, and the Constitution of International Society. Nova York: Oxford University Press, 2007, p. 121.
} 
esfera pública, no sentido de participação social e política, quanto à vida privada, no que toca à autodeterminação pessoal e moral. Nesse quadro, pode-se afirmar que a face positiva da liberdade, enquanto permissão para agir, possui um caráter público e um caráter privado, envolvendo tanto a liberdade política exercida na esfera pública, quanto a liberdade de definir os contornos da própria vida, referindo-se à liberdade na esfera privada.

Jorge Miranda trata das esferas pública e privada, referindo-se à distinção entre a liberdade civil e a política. Segundo o constitucionalista português, a liberdade civil, entendida como liberdade-autonomia, abrange os direitos da pessoa sob a perspectiva privada da sociedade civil; enquanto a liberdade política, ao mesmo tempo liberdade-autonomia e liberdade-participação, compreende tudo aquilo que é pertinente às relações do sujeito com o Estado, envolvendo a participação e os direitos políticos. ${ }^{298}$

No mesmo sentido, a lição de Joaquín Herrera Flores, ao mencionar dois tipos de liberdade: a primeira entendida como sinônimo de autonomia pessoal, gozada por todos os seres racionais e preservada em um espaço moral individual ideal; e a segunda concepção de liberdade, identificada com a possibilidade de construir espaços sociais para levar adiante as próprias lutas em busca da realização da dignidade humana, aproximada à política. ${ }^{299}$

Com base nas acepções de liberdade expostas, pode-se afirmar que o tema da transexualidade aproxima-se dos sentidos moderno, negativo, liberal e civil da liberdade, que concentram no indivíduo considerado em si mesmo o objeto de proteção. Isso porque a identidade de gênero pertence à esfera íntima, na qual a liberdade ganha o sentido de não-impedimento no perímetro de ação da pessoa, somente se admitindo restrições naquilo que causar dano a outrem, como consagrado pela Declaração Universal dos Direitos Humanos. Sob tal enfoque, a liberdade desdobra-se no direito à vida privada, tratado autonomamente na mesma Declaração Universal.

Por fim, a transexualidade pode ser analisada igualmente sob o prisma da liberdade em sentido positivo, relacionada à autodeterminação na escolha entre as alternativas de modos de vida ampliadas na modernidade, fundamentando, no plano jurídico, o direito ao desenvolvimento da personalidade.

\footnotetext{
${ }^{298}$ MIRANDA, Jorge. Manual de Direito Constitucional. Tomo IV, cit., p. 109.

${ }^{299}$ La construcción De Las Garantías. Hacia Una Concepción Antipatriarcal De La Libertad Y La Igualdad. In Sarmento, Daniel, Ikawa, Daniela e Piovesan, Flavia. Igualdade, Diferença e Direitos Humanos. Rio de Janeiro: Lúmen Juris, 2008, p. 119.
} 


\section{3) Liberdade e individualismo: da autodeterminação à}

\section{autorrealização pessoal}

Para a filosofia antiga, a estrutura do cosmos e a natureza humana ofereciam normas sobre o sentido de vida correta, normas essas que consistiam em modelo digno de imitação pelo indivíduo e pela comunidade política. As doutrinas da boa vida e da sociedade justa, como a ética e a política, inspiravam-se num todo comum, correspondente à totalidade da natureza, do que resultava a universalidade de exemplares modos de vida. A unidade essencial do mundo ético implicava a concepção de lei como princípio ético que não distinguia entre Direito, Moral e Religião, tratando-se de unidade que ultrapassou a antiguidade e perdurou durante a Idade Média Ocidental até o século XVI. ${ }^{300}$

Tal sistema ético, baseado na universalidade, atribuía diminuto relevo à liberdade individual e à singularidade de cada um. $\mathrm{O}$ acento positivo estava na subsunção da pessoa a condutas universais, do que resultavam poucas alternativas de comportamentos desejáveis.

O trajeto histórico que se seguiu, marcado pelas contribuições do Renascimento, da Reforma Protestante e do Iluminismo, pouco a pouco rompeu com a unidade do mundo ético e resultou em uma crescente valorização do indivíduo, marcada, no início da modernidade, pelo desaparecimento das estratificações típicas da Idade Média, abrindo-se à pessoa a possibilidade de construir a própria história com liberdade.

Radbruch identifica, no final do século XVIII, por influência de Kant, Schiller e Humboldt, a ascenção do valor cultural do indivíduo, livre, isolado e eticamente considerado o maior de todos os fins, assim se referindo à individualidade: "ciência e arte apenas como matéria para formação daquela, direito e Estado apenas como instituições para seu asseguramento". 301

O valor da liberdade aplicado ao indivíduo resultou nas ideias de autorrealização e autodeterminação, desenvolvidas a partir da segunda metade do século XVIII, que difundiram, entre outras, a noção de responsabilidade pela própria história de vida individual, em substituição às instruções para uma forma de vida virtuosa. ${ }^{302}$

\footnotetext{
${ }^{300}$ COMPARATO, Fabio Konder. Ética. Direito, moral e religião no mundo moderno, cit., p. 150.

${ }^{301}$ RADBRUCH, Gustav. Introdução à ciência do direito. Tradução de Vera Barkow. São Paulo: Martins Fontes, 1999, p. 10.

${ }^{302}$ HABERMAS, Jürgen. Direito e Democracia: entre facticidade e validade. Vol I, $2^{\text {a }}$ ed. Tradução de Flavio Beno Siebeneichler. Rio de Janeiro: Tempo Brasileiro, 2003, p. 129.
} 
No século XIX, a obra Sobre a liberdade, de Stuart Mill, apontada como "uma das mais nobres e apaixonadas defesas da liberdade", tendente a transformá-la num ideal ou valor em $\mathrm{si}^{303}$ reflete os valores de seu tempo.

Para Stuart Mill, só seria legítimo interferir em assuntos que dissessem respeito ao próprio indivíduo (self-regarding matters), sem sua concordância expressa, por razões de autoproteção, ${ }^{304}$ revelando a diminuta esfera de ingerência que admitia ao poder estatal. Entendia o autor a individualidade como uma expressão da liberdade, no sentido de permitir ao indivíduo dirigir sua vida a partir do próprio íntimo e não com base nos costumes ou tradições de outras pessoas. Ressaltava que a existência de diferentes experiências de vida, desde que não causassem dano a outrem, era importante inclusive para a evolução da humanidade. ${ }^{305}$

O desenvolvimento da individualidade, no sentido empregado por Mill, pressupõe a capacidade de escolha pela pessoa, cabendo-lhe "descobrir que parte da experiência disponível é adequadamente aplicável às suas próprias circunstâncias e ao seu próprio carácter", ${ }^{306}$ acentuando o âmbito privado da liberdade, naquilo que se refere à construção do próprio $e u$. A liberdade de escolha, acrescenta Mill, implica o uso das faculdades humanas da percepção, do juízo e discernimento, da atividade mental e até da preferência moral, por meio dos poderes humanos intelectuais e mentais, para o que não basta a imitação de qualquer regra de costume: "Aquele que faz algo porque é o costume, não faz qualquer escolha", sustentando que "a única fonte inabalável e permanente de desenvolvimento é a liberdade". 307

Como assinala Habermas, a liberdade refletiu-se na exigência da busca pela autorrealização e incorporou-se às ideias normativas da modernidade, com o sentido de valorização da realização individual: “A conduta consciente da vida da pessoa singular mede-se pelo ideal expressivista da auto-realização, pela ideia deontológica da liberdade e pela máxima utilitarista da multiplicação das chances individuais de vida". 308 Analisa o autor que, a partir do século XVIII, pouco a pouco a ideia de sociedade justa passou a se identificar com aquela própria do mundo moderno, que "deixa ao critério de

\footnotetext{
303 ABBAGNANO, Nicola. Dicionário de filosofia. Tradução de Alfredo Bosi. São Paulo: Martins Fontes, 2003, verbete liberalismo, p. 605.

${ }^{304}$ Sobre a Liberdade. Tradução de Pedro Madeira. Lisboa: Edições 70, 2006, p.VIII/IX.

${ }^{305}$ MILL, John Stuart. Sobre a Liberdade. Tradução Pedro Madeira. Lisboa: Edições 70, 2006, p. 106.

${ }^{306}$ Idem, p. 109.

${ }^{307}$ Idem, p. 109 e 126.

${ }^{308}$ HABERMAS, Jürgen. Direito e Democracia: entre facticidade e validade. Vol I, $2^{\mathrm{a}}$ ed. Tradução de Flavio Beno Siebeneichler. Rio de Janeiro: Tempo Brasileiro, 2003, p. 132.
} 
todas as pessoas aquilo que elas querem "iniciar com o tempo de suas vidas", 309 em substituição à tentativa filosófica de designar determinados modos de vida como universalmente decisivos.

Essa concepção de liberdade voltada à autorrealização reflete-se diretamente na construção da identidade individual.

De acordo com Michelangelo Bovero, a ideia de independência do sujeito possui um conteúdo negativo, referente à emancipação da pessoa em relação às formas comunitárias pré-modernas, e um conteúdo positivo. Este último, afirma o italiano, consiste na liberdade virtual de juízo e de ação, do sujeito em relação ao grupo. A partir daí, afirma Bovero a primazia da identidade individual sobre a coletiva, uma vez que a segunda passa a depender não do lugar atribuído pelo nascimento, mas da representação que o sujeito faz de si mesmo, como membro integrante de determinado grupo. ${ }^{310}$

Igualmente para Zygmunt Bauman, a identidade moderna está intimamente relacionada com a independência do sujeito, alcançada pela liberdade individual.

Segundo o autor, o mundo moderno é definido como líquido, caracterizado pela rápida transformação das instituições e pela inexistência de extratos sociais fixos, de modo que a identidade não mais se reveste de solidez, nem é imutável, dependendo das escolhas que a pessoa realiza pela vida. ${ }^{311}$ Bauman aponta a individualização como o resultado dessa liberdade no mundo moderno, em consequência da emancipação do indivíduo, liberto da determinação atribuída, herdada e inata, o que permite transformar a ideia de identidade humana de uma coisa dada em um construído, encarregando os atores da responsabilidade de desempenhar essa tarefa e arcar com as respectivas consequências. ${ }^{312}$

No mesmo sentido, refere-se Bovero à "escolha de si mesmo" (“scelta di se stesso"), que é possibilitada ao indivíduo, diante da ampla gama de opções que se apresentam na sociedade moderna, na contínua definição e elaboração do próprio interesse, desejos e aspirações, em busca da própria identidade pessoal. ${ }^{313}$

\footnotetext{
${ }^{309}$ HABERMAS, Jürgen. O futuro da natureza humana. São Paulo:Martins Fontes, p. 03.

${ }^{310}$ BOVERO, Michelangelo.Identità individuali e collettive. In Ricerche politiche due. Identità, interessi e scelte collettive. il Saggiatore, Milano, 1983, p. 32.

${ }^{311}$ Identidade: entrevista a Benedetto Vecchi. Tradução de Carlos Alberto Medeiros. Rio de Janeiro: Jorge Zahar, 2005, p. 17/18 e 21/22.

312 BAUMAN, Zigmunt. Identidade no mundo globalizante. In A sociedade individualizada: vidas contadas e histórias vividas. Tradução de José Gradel. Rio de Janeiro: Jorge Zahar, 2008, p. 183.

${ }^{313}$ BOVERO, Michelangelo.Identità individuali e collettive. In Ricerche politiche due. Identità, interessi e scelte collettive, cit., p. 55.
} 
Aponta Andrew Hurrell que essa concepção de liberdade se reflete no cenário internacional, influindo na atual concepção de soberania dos povos. De acordo com o autor, a identidade do povo em abstrato, vislumbrada em termos cívicos, sobre a qual se assentava a ideia de soberania, não se mostra mais suficiente. Em seu lugar, ganha importância a noção de soberania calcada na identidade de um povo em particular, com uma história específica e consciência de si mesmo. Daí a substituição da ideia amorfa de soberania popular, pela ideia de nação, com forte apelo emocional. Nesse sentido, acrescenta Hurrell que o crescimento do nacionalismo cultural e linguístico na Europa decorre, entre outros fatores, da valorização do único e do particular sobre o universal, e da ideia pré-romântica de que o valor moral se assenta nos sentimentos e percepções individuais e não em razões ou leis universais. ${ }^{314}$

No fim do século XX, Axel Honneth aprofunda o exame da liberdade dirigida à autorrealização humana. Para o autor, a autorrealização deve ser entendida como uma forma de alcançar as metas de vida eleitas pela pessoa com autonomia, ressalvando o especial significado que empresta à espontaneidade e à liberdade. Anota Honneth que a liberdade não pode se referir simplesmente à ausência de coerção, devendo ser compreendida como "ao mesmo tempo a falta de bloqueio interno, de inibição psíquica e de angústias" e "uma espécie de confiança dirigida para fora, que oferece ao indivíduo segurança tanto na expressão das carências como na aplicação de suas capacidades". 315

Honneth afirma a necessidade da liberdade para possibilitar à pessoa alcançar sua autorrealização, a qual consiste no objetivo da eticidade que propõe por meio da luta por reconhecimento.

Percebe-se, destarte, que a proposta de Honneth acrescenta à ideia de autodeterminação como ausência de coerção externa uma noção ampliada de liberdade, estendida à esfera psíquica da pessoa, ou seja, de ausência de coerção interna. Inclui, também, na autodeterminação como poder de obedecer à própria lei, uma exigência de condições pessoais e ausência de bloqueio psíquico, para ele obtida por meio da confiança no reconhecimento pelo grupo, que permitam à pessoa alcançar sua autorrealização, incorporando-a entre os sentidos da liberdade.

\footnotetext{
${ }^{314}$ Nationalism and the politics of identity. In On global order. Power, Values, and the Constitution of International Society. Nova York: Oxford University Press, 2007, p. 124/125.

${ }^{315}$ HONNETH, Axel. Luta por reconhecimento. A gramática moral dos conflitos sociais. Tradução de Luiz Repa. São Paulo: Ed. 34, 2ª Ed., 2009, p. 273.
} 
Em sua teoria, inclusive a liberdade se insere no contexto relacional da intersubjetividade, na medida em que a liberdade de autorrealização depende de condições somente adquiridas por meio do reconhecimento entre os parceiros de interação, ${ }^{316}$ entre as quais ele cita a confiança e a segurança para livremente se revelar ao outro. A liberdade, originalmente entendida por Hobbes como direito natural, inato e individual, ganha um significado complementar, transcendendo a ideia de liberdade abstrata, do indivíduo isolado, para alcançar uma dimensão concreta e coletiva. Nesta, a liberdade expressa-se por condições pessoais e internas para realizar escolhas livres, tratando-se de uma esfera íntima e psíquica de exercício da liberdade, adquirida em interação.

Nessa esteira, pode-se afirmar que a liberdade assegura à pessoa uma ampla esfera de não-impedimento, ou de ausência da ingerência estatal em aspectos da vida privada que só lhe dizem respeito e que se lhe afiguram relevantes para a autorrealização, ao mesmo tempo queo reconhecimento recíproco do direito de liberdade amplia as condições de mútuo respeito, de confiança e segurança para assumir e expressar as escolhas íntimas, perante a coletividade.

Dado o objeto do estudo, importante consignar, então, que a escolha pela aparência e modo de vida típicos do outro sexo, que caracteriza a transexualidade, guarda proteção e amparo jurídico sob o direito de liberdade, naquilo que assegura à pessoa uma ampla margem de opções dirigidas à autorrealização. $\mathrm{O}$ respeito a tais escolhas, outrossim, contribui para a expansão da liberdade do próprio grupo, na medida em que, inspirando a confiança de que a expressão da liberdade de um será por todos respeitada, estimular-se-ão escolhas livres por todos os parceiros de interação.

Por fim, apenas para adiantar, insuficiente afigura-se o plano da liberdade para a garantia da dignidade dos transexuais, já que o respeito envolve a proteção jurídica à sua identidade, que será tratada sob o ângulo da igualdade, a partir de uma dimensão pública e relacional revelada pela necessidade de inclusão, por meio do reconhecimento de direitos no plano jurídico.

Por ora, prosseguindo no estudo da liberdade, passa-se ao tema da autonomia e sua relação com a construção da identidade.

\footnotetext{
${ }^{316}$ Idem, mesma página.
} 


\section{4) A autonomia, pela perspectiva filosófica}

Como exposto, a liberdade, no sentido de direito de autodeterminação, possui âmbitos negativo e positivo, implicando simultaneamente uma exigência de abstenção do Estado em proteção à intimidade e uma possibilidade de agir, participar e ditar as próprias leis. Nessa quadra, o direito de autodeterminação aproxima-se da noção de autonomia, tema aprofundado por Kant e que ganhou contornos próprios no direito.

A pertinência do aprofundamento da noção de autonomia sob o enfoque da filosofia justifica-se pela necessidade de compreender os conteúdos normativos que impregnam o conceito e, portanto, os reflexos da limitação jurídica à mudança do gênero do transexual, sob o ponto de vista da liberdade.

É verdade que, como ressalta Paul Ricouer, nem tudo que interfere na identificação resulta da liberdade do indivíduo, reconhecendo-se a existência de fatores objetivos e independentes da vontade do titular, atuantes na formação da identidade, como, no exemplo do autor, o lugar fixo atribuído pelo nascimento. Nesse sentido, anota Ricoeur a anterioridade do status civil familiar em relação à identidade individual do sujeito, afirmando: "é esse lugar que, antes de qualquer conscientização egológica, confere-me aos olhos da instituição civil a identidade designada pelos termos filho de, filha de. Concentrando-me na significação que tem para mim essa identidade civil, descubro com surpresa que, antes de poder pensar em mim mesmo e de ser sujeito de percepção, de ação, de imputação, de direito, fui e continuo a ser esse "objeto", essa res". 317

Ocorre que a assunção da dignidade da pessoa humana como princípio axiológico fundamental que vincula a interpretação do ordenamento impõe a consideração da pessoa como sujeito e não como objeto, coisa ou instrumento, ${ }^{318}$ ultrapassando-se a identificação original decorrente do nascimento, sem qualquer escolha própria, na direção de uma identidade delineada pela pessoa, com autonomia. Daí a relevância de aprofundar o significado e o sentido da autonomia e sua relação para a formação da identidade individual. Trata-se, destarte, da autonomia relacionada ao direito civil e aos direitos da personalidade, "da pessoa na modelação imediata de sua vida quotidiana", que reconhece o sujeito "como actor capaz de decidir o curso dos

\footnotetext{
${ }^{317}$ RICOEUR, Paul. Percurso do Reconhecimento. Tradução de Nicolás Nyimi Campanário. São Paulo: Edições Loyola, 2006, p. 207.

${ }^{318}$ MIRANDA, Jorge. Manual de Direito Constitucional. Tomo IV, cit., p. 200.
} 
acontecimentos, com liberdade relativa num quadro de relativo indeterminismo", ligada ainda "à biologia, à antropologia, à psicologia, à economia ou às chamadas relações de produção". 319

A autonomia está implicitamente referida no art. $1^{\circ}$ da Declaração Universal dos Direitos Humanos, na alusão à razão e consciência dos homens como denominador comum que garante a liberdade, a igualdade e a dignidade: "Todos os seres humanos nascem livres e iguais em dignidade e direitos. Dotados de razão e de consciência devem agir uns para com os outros em espírito de fraternidade".

A menção à razão e consciência como instrumentos para decidir por si em espírito de fraternidade remete à ideia de autonomia desenvolvida por Kant, para quem a autonomia da vontade consiste na faculdade de determinar a si mesmo e de agir em conformidade com a representação de certas leis, entendendo que o direito de autonomia não pode ser exercido sem um mínimo de competência ética. ${ }^{320}$ Kant contrapôs a autonomia à heteronomia, distinguindo-as com base na origem da causa eficiente para a ação. Assim, entende autônoma a conduta iniciada por uma lei autoimposta, e heterônoma a ação decorrente de uma causa externa, ressaltando a relevância do papel da razão e da consciência na autodeterminação. Acrescenta que o desejo motivador da ação autônoma deve corresponder a uma máxima que possa ser convertida em lei universal, de modo que, para Kant, o desejo e o cumprimento do dever moral perfazem uma unidade ideal. ${ }^{321}$

Como anota Paton, a harmonização da concepção kantiana de autonomia com o pressuposto de liberdade não é simples e pressupõe algumas premissas: 1) o desejo deve obedecer a um tipo específico de lei; 2) admitido que toda lei é autoimposta ou imposta por terceiros, a lei de liberdade deve necessariamente ser autoimposta; 3) a lei autoimposta pode prescrever apenas um dever: o de obedecer à lei e cumpri-la enquanto tal. ${ }^{322}$

No imperativo categórico, Kant assenta que o móvel da conduta deve corresponder a uma máxima universal, sempre considerando o ser humano como fim e nunca como meio: Age apenas segundo uma máxima tal que possas ao mesmo tempo querer que ela se torne lei universal. (...)Age de tal maneira que uses a humanidade, tanto

\footnotetext{
${ }^{319}$ MOTA PINTO, Carlos Alberto da. Teoria Geral do Direito Civil. Coimbra: Coimbra Editora, 1999, p. 83 , nota 1.

${ }^{320}$ SARLET. Ingo Wolfgang. Dignidade da pessoa humana e direitos fundamentais na Constituição de 1988. Porto Alegre: Livraria do Advogado Editora, 2010, p. 37.

${ }^{321}$ PATON. H. J. The Categorical Imperative. A study in Kant's moral philosophy. Philadelphia: University of Pennsylvania Press, 1971, p. 212.

${ }^{322}$ Idem, mesma página.
} 
na sua pessoa como na pessoa de qualquer outro, sempre e simultaneamente como fim e nunca simplesmente como meio, ${ }^{323}$ agregando um componente moral na noção de autonomia.

Desse modo, atribui-se a Kant a vinculação da autonomia à dignidade, já que o filósofo entende a racionalidade e a moralidade como fundamentos e conteúdos da dignidade. ${ }^{324}$

Prosseguindo no estudo da autonomia e de sua relação com a liberdade, cumpre acrescentar o tema da subjetividade.

Habermas, ao tratar da consciência de tempo da modernidade e de sua necessidade de autocertificação, afirma que, embora em Kant já se expresse a autocompreensão da modernidade, Hegel foi o primeiro filósofo a tomar como problema o processo pelo qual a modernidade se desliga das tradições normativas do passado, numa perspectiva crítica. ${ }^{325}$ De acordo com Habermas, Hegel, preocupado em situar a filosofia nos novos paradigmas, identifica como princípio dos tempos modernos a subjetividade, que confere ao sujeito a liberdade de se reconhecer em si: “A grandeza do nosso tempo é o reconhecimento da liberdade, a propriedade do espírito pela qual este está consigo mesmo", 326 introduzindo uma concepção de autorrelação do sujeito consigo mesmo, posteriormente retomada por Axel Honneth. Neste trabalho, dado o interesse para o tema, a referência a Hegel limita-se ao conceito de subjetividade, sem a preocupação de ingressar no conceito hegeliano de eticidade, ou moralidade objetiva, contraposto às ideias de direito abstrato individual e de moralidade subjetiva kantiana. ${ }^{327}$

Esclarece Habermas que a expressão subjetividade comporta quatro conotações. A primeira conotação de subjetividade refere-se ao individualismo, pois, na modernidade, reconhece-se ao particular o direito de fazer valer suas pretensões. A segunda admite o direito de crítica como princípio do mundo moderno, segundo o qual aquilo que deve ser reconhecido por todos deve se mostrar a cada um como legítimo. $\mathrm{O}$ terceiro significado de subjetividade identificado por Habermas está ligado à autonomia da ação, no sentido de que "queiramos responder pelo que fazemos"; enquanto a quarta e

\footnotetext{
${ }^{323}$ Fundamentação da metafísica dos costumes. Lisboa: Edições 70, 2000, p. 59 e 69.

${ }^{324}$ SARLET. Ingo Wolfgang. Dignidade da pessoa humana e direitos fundamentais na Constituição de 1988. Porto Alegre: Livraria do Advogado Editora, 2010, p. 39.

${ }^{325}$ HABERMAS, Jurgen. O discurso filosófico da modernidade. Tradução de Luiz Sérgio Repa e Rodnei Nascimento. São Paulo: Martins Fontes, 2002, p. 24.

${ }^{326}$ Idem, p. 25.

${ }^{327}$ MASCARO, Alysson Leandro. Filosofia do Direito. São Paulo: Atlas, 2010, p. 251.
} 
última conotação se refere à própria filosofia idealista, ou à apreensão pela filosofia da ideia de si mesma. ${ }^{328}$

Em relação aos conceitos morais, o princípio da subjetividade resulta no reconhecimento da liberdade pessoal do indivíduo, autorizando o sujeito a definir o que é válido para si, mediante a exigência de que persiga seu bem-estar particular em consonância com o bem-estar dos outros: “A vontade subjetiva ganha autonomia sob leis universais; mas 'só na vontade, enquanto subjetiva, pode a liberdade, ou a vontade que é em si, ser efetiva'".329

Acrescida da noção de subjetividade, assim, a autonomia distancia-se do dever moral universal kantiano e aproxima-se do desejo individual e livre do sujeito, dirigido a construir uma boa relação consigo mesmo.

Stuart Mill relaciona autonomia, liberdade e felicidade. Para o autor, o desenvolvimento autônomo da pessoa é um dos principais ingredientes da felicidade humana, essencial ao desenvolvimento individual e social, identificando a maior dificuldade no fato de as pessoas não reconhecerem o valor intrínseco e nem manifestarem respeito à espontaneidade individual. ${ }^{330}$ Sua ideia vincula a autonomia à ampla liberdade típica da espontaneidade, entendida como "a capacidade de manifestar fluência emocional à autenticidade de propósitos para agir livremente e criar, sem cessar, formas inéditas de interação conosco, com os outros e com o mundo". 331

Percebe-se, a partir daí, uma mudança em relação ao conteúdo da autonomia: da proposta kantiana de difícil harmonização com a liberdade, como ressaltado por Paton, para uma concepção de autonomia que agrega valor à vontade subjetivamente considerada e à espontaneidade, não necessariamente vinculada a uma máxima universal.

Atualmente, a autonomia pode ser entendida como a capacidade de dirigir-se, de escolher e criar seus objetivos, optar por certa visão de mundo e agir de acordo com isso; ${ }^{332}$ ou como "a possibilidade de decidir sem condicionamentos externos", 333 de todo modo se reconhecendo uma flexibilização do sentido original

\footnotetext{
${ }^{328}$ HABERMAS, Jurgen. O discurso filosófico da modernidade, cit., p. 25/26.

${ }^{329}$ Idem, p. 27.

${ }^{330}$ MILL, John Stuart. Sobre a Liberdade, cit., p. 107.

${ }^{331}$ COSTA, Jurandir Freire. psicanalista e professor de Medicina Social na Universidade do Estado do Rio de Janeiro, em artigo "O direito à espontaneidade", Folha de São Paulo, 09/09/2010.

${ }^{332}$ PAMPLONA DA COSTA, Ronaldo. Homossexualidade: saúde x doença. In Bioética e sexualidade. Org: Tereza Rodrigues Vieira, p. 69.

333 LORENZETTI, Ricardo Luis. Fundamentos do Direito Privado. Tradução de Vera Maria Jacob de Fradera. São Paulo: Revista dos Tribunais, 1998, p. 502.
} 
empregado por Kant. Como anota Nicola Abbagnano, fala-se mais genericamente em “"princípio autônomo' no sentido de um princípio que tenha em si, ou ponha por si mesmo, a sua validade ou a regra de sua ação". 334

Juridicamente, a autonomia da vontade refere-se à manifestação da liberdade sob o aspecto subjetivo, como "o poder da pessoa estabelecer, pelo exercício de sua vontade, o nascimento, a modificação e a extinção de suas relações jurídicas"; 335 enquanto sob o aspecto objetivo, a liberdade corresponde à autonomia privada, ou poder jurídico normativo de "criar juridicamente essas relações, estabelecendo-lhes o respectivo conteúdo e disciplina”. 336

\section{5) A identidade como expressão moral da pessoa}

A identidade é um problema central da modernidade. Algo a ser construído, em herança à liberdade de autoexpressão legitimada pelo Romantismo. ${ }^{337}$

Na lição de Michelangelo Bovero, a identidade é, acima de tudo, um problema lógico e ontológico, relacionado ao mesmo tempo à alteridade, à diferença $\mathrm{e}$ à igualdade, ${ }^{338}$ implicando o afirmar-se singular, entre iguais. É, pois, um problema psicológico e antropológico, referindo-se à subjetividade do homem, ao próprio eu e, em última instância, à noção moderna de consciência e autoconsciência. ${ }^{339}$

Bovero vislumbra na identidade uma representação da pessoa natural, um modo e uma forma de ser que o indivíduo fornece de si mesmo, em suas relações com os outros. Nesse sentido, afirma que as dicotomias indivíduo-coletividade e identidade individual - identidade coletiva são correspondentes, mas não coincidentes, equivalendo mais ou menos à dicotomia realidade e representação. ${ }^{340} \mathrm{~A}$ pessoa estaria, então, no plano da vida, enquanto a identidade seria sua projeção. Sugere o autor italiano que se entenda por identidade o conjunto dos predicados, características e determinações apontado pelo sujeito para responder à indagação: “quem és?”. ${ }^{341}$ Acrescenta que a

\footnotetext{
${ }^{334}$ Dicionário de Filosofia. São Paulo: Martins Fontes, 2003, p. 98.

${ }^{335}$ AMARAL, Francisco. Direito Civil. Introdução, $7^{\text {a }}$ ed. Rio de Janeiro: Renovar, 2008, p. 22,

${ }^{336}$ Idem, mesma página.

${ }^{337}$ LAFER, Celso. Identidade individual e identidade coletiva: o judaísmo e os dilemas da modernidade. In Ensaios Liberais. São Paulo: Siciliano, 1991, p. 183.

${ }^{338}$ BOVERO, Michelangelo. Identità individuali e collettive. In Ricerche politiche due. Identità, interessi e scelte collettive, cit., p. 33

${ }^{339}$ Idem, mesma página.

${ }^{340}$ Idem, p. 31.

${ }^{341}$ Idem, p. 34.
} 
possibilidade de independência moral da pessoa é resultante de seu comportamento em face da estrutura da vida social. ${ }^{342}$

Também para Charles Taylor, a construção da identidade moderna é tema entrelaçado com a moralidade, exigindo o aprofundamento conjunto da individualidade e do bem.

$\mathrm{Na}$ análise do autor, as reações morais podem ocorrer em dois planos. O primeiro, denominado instintivo, envolve as reações humanas viscerais e inatas, como socorrer alguém em perigo; enquanto o segundo resulta da ação da cultura e da educação sobre a natureza, dando forma e contornos descritivos à reação moral. Afirma: “A cultura e a criação podem ajudar a definir as fronteiras dos "outros" relevantes, mas não parecem criar a reação básica em si". 343

Charles Taylor, em que pese considerar a identidade complexa e multifacetada, arrisca um conceito: "Minha identidade é definida pelos compromissos e identificações que proporcionam a estrutura ou o horizonte em cujo âmbito posso tentar determinar caso a caso o que é bom, ou valioso, ou o que se deveria fazer ou aquilo que endosso ou a que me oponho. Em outros termos, trata-se do horizonte dentro do qual sou capaz de tomar uma posição". ${ }^{44}$ Acrescenta nossa compreensão pós-romântica das diferenças individuais à tradição da universalidade e assevera: "Somos todos moldados pelo que julgamos compromissos universalmente válidos (ser católico ou anarquista, em meu exemplo acima), bem como por aquilo que compreendemos como identificações particulares (ser armênio ou nativo de Quebec)". 345

A partir de tais lições, autorizado reconhecer um elemento axiológico na composição da identidade, uma interdependência entre a identidade e a moralidade, no sentido de que as crenças e valores próprios acabarão moldando a forma pela qual a pessoa será conhecida e identificada no meio social, delineando os contornos de sua identidade. Tal concepção encerra também a capacidade de se posicionar e agir orientado por valores, incluindo a ação e a autonomia entre os elementos confluentes na composição da identidade. Assim, a identidade corresponde, ao mesmo tempo, à essência e à forma de expressão da pessoa, cujo respeito é essencial para a dignidade humana.

\footnotetext{
${ }^{342}$ Idem, p. 41.

${ }^{343}$ TAYLOR, Charles. As fontes do self. A construção da identidade moderna. Tradução Adail Ubirajara Sobral e Dinah de Abreu Azevedo, 2a ed. São Paulo: Edições Loyola, 2005, p. 17.

${ }^{344}$ Idem, p. 44.

${ }^{345}$ Idem, p. 45.
} 
Bem por isso, na lição de Hannah Arendt, a resposta à pergunta “quem és?" pressupõe a revelação de quem chega, por meio do discurso e da ação. De acordo com a autora, "Na ação e no discurso, os homens mostram quem são, revelam ativamente suas identidades pessoais e singulares, e assim apresentam-se ao mundo humano, enquanto suas identidades físicas são reveladas, sem qualquer atividade própria, na conformação singular do corpo e no som singular da voz", ${ }^{346}$ numa interação entre o mundo interior e exterior sintetizada na identidade.

John Rawls distingue, a partir do conceito normativo de pessoa livre e igual, uma identidade pública ou legal e uma identidade não-legal, ou moral. Associa a identidade pública à faculdade moral que todos possuem de reivindicar o direito de serem considerados como pessoas, independentemente de sua própria concepção de bem, relacionando-a à identidade em termos de direito fundamental. $\mathrm{O}$ outro sentido de identidade, que o autor denomina não-legal ou moral, refere-se aos objetivos e engajamentos mais profundos do cidadão, às suas convicções religiosas, filosóficas e morais, às suas lealdades permanentes. Sobre a relevância da identidade como âncora moral para a percepção de si mesmo, sintetiza Rawls:

“Esses dois tipos de engajamentos e afinidades - políticos e nãopolíticos - determinam a identidade moral de uma pessoa e dão forma ao seu modo de vida e àquilo que uma pessoa entende que está fazendo e está tentando realizar no mundo social. Se os perdêssemos de repente, ficaríamos perdidos e incapazes de seguir em frente". ${ }^{347}$

Pode-se, então, concluir das lições de Michelangelo Bovero, Charles Taylor, Hannah Arendt e Rawls que a identidade revelada pela resposta à indagação "Quem sou eu" não se resume ao nome e genealogia, mas inclui as escolhas, as referências morais da pessoa e sua orientação, expressadas no convívio em grupo. Ou seja, do conflito moral interior, que "não se realiza entre homens; ocorre no indivíduo isolado, no próprio peito, em diálogo silencioso entre cobiça e consciência, entre nosso eu comum e nosso eu melhor, entre a criatura e o criador", ${ }^{348}$ resulta uma opção axiológica pessoal que se torna pública e compõe a identidade do Ser.

No processo de identificação igualmente influem referências universais.

\footnotetext{
${ }^{346}$ ARENDT. Hannah. A condição humana. Tradução de Roberto Raposo, posfácio de Celso Lafer, $10^{\mathrm{a}}$ ed. Rio de Janeiro: Forense Universitária, 2001.

${ }^{347}$ RAWLS, John. Justiça como eqüidade. Uma reformulação. Tradução de Claudia Berliner. São Paulo: Martins Fontes, 2003, p. 31.

${ }^{348}$ RADBRUCH, Gustav. Introdução à ciência do direito, cit., p. 7.
} 
A importância dessas referências para a formação da identidade, como anota Habermas, decorre da própria organização coletiva humana. O filósofo, após afirmar que a identidade pós-tradicional baseia-se numa interiorização em busca do autoconhecimento, refletindo o individualismo de uma particular história de vida, pondera: "Ao mesmo tempo, as normas de convivência tornam-se reflexivas e impõem-se orientações de valores universalistas". 349

Entre as referências comuns compartilhadas socialmente, Charles Taylor destaca o valor da vida e da integridade, ${ }^{350}$ entendendo por respeito à integridade das pessoas "a proteção à sua liberdade expressiva de exprimir e desenvolver suas próprias opiniões, definir suas próprias concepções de vida, criar seus próprios planos de vida". 351

A identidade, sob o ponto de vista moral, inclui, assim, de um lado, a síntese particular entre as crenças e valores universais e individuais, que ocorre no âmago do indivíduo; e, de outro, a capacidade do sujeito de agir na mesma respectiva direção, com autonomia. Compõe-se, nesse sentido, da singularidade que identifica e distingue cada pessoa na pluralidade da vida coletiva, para usar expressões de Hannah Arendt.

A proteção da dignidade pressupõe, nessa quadra, o respeito à individualidade que se expressa por uma identidade, combinando-se o plano abstrato e universal da dignidade com a existência concreta e singular do Ser, no pressuposto de que a dignidade "é da pessoa concreta, na sua vida real e quotidiana; não é de um ser ideal e abstracto. É o homem ou a mulher, tal como existe, que a ordem jurídica considera irredutível, insubstituível e irrepetível e cujos direitos fundamentais a Constituição enuncia e protege". 352

Como anota Paul Ricoueur: "à versão universalizante da dignidade se acrescentou a afirmação de uma identidade individualista, que pode reivindicar sua filiação a Rousseau e a Herder". 353

Neste ponto, o estudo desdobra-se em duas frentes. Uma primeira relacionada à igualdade, como direito fundamental que, ao lado da liberdade, fundamenta a tutela dos transexuais; e uma segunda, ainda sob o enfoque da liberdade, mas

\footnotetext{
${ }^{349}$ HABERMAS, Jurgen. Direito e Democracia: entre facticidade e validade, vol I, cit., p. 131.

${ }^{350}$ TAYLOR, Charles. As fontes do self. A construção da identidade moderna, cit., p. 19.

${ }^{351}$ Idem, p. 41.

${ }^{352}$ MIRANDA, Jorge. Manual de Direito Constitucional. Tomo IV, cit., p. 200/201

${ }^{353}$ RICOEUR, Paul. Percurso do Reconhecimento, cit., p. 228.
} 
agora especificamente voltada à vida privada e ao desenvolvimento da personalidade, na premissa de que: "A dignidade determina respeito pela liberdade da pessoa, pela sua autonomia. A força da autonomia patenteia-se sobretudo no direito ao desenvolvimento da personalidade". 354

Por questões metodológicas, prossegue-se no estudo da liberdade e seus desdobramentos para a proteção da pessoa, reservando-se a igualdade para mais adiante.

6) Direitos de liberdade no ordenamento brasileiro: a vida privada e o livre desenvolvimento da personalidade

\section{6.a) $\mathrm{O}$ direito à vida privada}

O direito à vida privada inicia o elenco das liberdades, protegidas pela Declaração Universal dos Direitos do Homem.

Celso Lafer, baseado na leitura que aprofunda sobre Hannah Arendt, aponta diferenças de objetivos e de preocupações que comandam a vida pública e a vida privada. Afirma o professor que os interesses individuais são pautados pelo horizonte particular da vida de cada um, frequentemente em choque com o bem comum, orientado por interesses públicos. Daí a contestação à ideia de que do jogo de interesses individuais necessariamente resulte o interesse público, ${ }^{355}$ fazendo-se necessário harmonizar o valor da liberdade individual com o bem comum. Essa harmonização é pretendida pela tutela da vida privada.

$\mathrm{Na}$ análise do professor Lafer, existem duas acepções básicas para a compreensão das esferas do público e do privado. A primeira baseia-se na acessibilidade, definindo-se como público aquilo que é acessível a todos; em contraposição ao privado, que se refere ao reservado e pessoal. Já pelo segundo critério, público é o que afeta a todos ou a maioria, enquanto privado afeta a um ou a poucos. ${ }^{356}$ Citando Hannah Arendt, o professor acrescenta que a distinção entre o privado e o público equivale à diferença entre o que deve e pode ser mostrado e o que deve e pode ser ocultado. ${ }^{357}$

\footnotetext{
${ }^{354}$ MIRANDA, Jorge. Manual de Direito Constitucional, cit., p. 209.

${ }^{355}$ LAFER, Celso. A reconstrução dos direitos humanos, cit., p. 237.

${ }^{356}$ Idem, p. 243.

${ }^{357}$ Idem, p. 261
} 
Traçada essa breve distinção entre público e privado, passa-se a investigar o tema da transexualidade sob o ângulo da liberdade, no que se refere ao direito à vida privada ou à intimidade.

$\mathrm{O}$ direito à privacidade corresponde à liberdade dos modernos, na nomenclatura de Benjamin Constant, à autonomia da conduta individual. ${ }^{358}$ Não constava expressamente das primeiras Declarações de Direitos, do século XVIII, mas também não é novo, reconhecido há mais de um século nos Estados Unidos, por meio da fórmula "the right to be let alone" utilizada por Brandeis, em artigo escrito em parceria com Samuel Dennis Warren e publicado na Harvard Law Review em $1890{ }^{359}$ Coincide com as liberdades públicas clássicas naquilo que impõe ao Estado um não-fazer, refletindo a dignidade humana cuja principal expressão é a liberdade. ${ }^{360}$

$\mathrm{O}$ direito à vida privada está positivado no artigo XII, da Declaração Universal dos Direitos Humanos, de 1948: "Ninguém será sujeito a interferências na sua vida privada, na sua família, no seu lar ou na sua correspondência, nem ataques à sua honra e reputação. Toda pessoa tem direito à proteção da lei contra tais interferências ou ataques". ${ }^{361}$ Encontra-se igualmente no art. 17, do Pacto da ONU sobre direitos civis e políticos, de 1966, no art. 11, da Convenção Americana de 1969, sobre os direitos do homem (Pacto de São José da Costa Rica), e no art. $8^{\circ}$, da Convenção Europeia de 1950, que vem sendo aplicado pela Corte Europeia de Direitos Humanos para a tutela dos transexuais: "1.Qualquer pessoa tem direito ao respeito de sua vida privada e familiar, do seu domicílio e de sua correspondência. 2. Não pode haver ingerência da autoridade pública no exercício deste direito senão quando esta ingerência estiver prevista na lei e constituir uma providência que, numa sociedade democrática, seja necessária para a segurança nacional, para a segurança pública, para o bem-estar econômico do país, a defesa da ordem e a prevenção das infrações penais, a proteção da saúde ou da moral, ou a proteção dos direitos e das liberdades de terceiros". ${ }^{362}$

No Brasil, o direito à vida privada está expresso no art. $5^{\circ}, \mathrm{X}, \mathrm{da}$ Constituição Federal: "São invioláveis a intimidade, a vida privada, a honra e a imagem

\footnotetext{
${ }^{358}$ FERREIRA FILHO, Manoel Gonçalves. Aspectos de direito constitucional contemporâneo. $2^{\mathrm{a}}$ ed. São Paulo: Saraiva, 2009, p. 307.

${ }^{359}$ LAFER, Celso. A reconstrução dos direitos humanos, cit., p. 239.

${ }^{360}$ FERREIRA FILHO, Manoel Gonçalves. Aspectos de direito constitucional contemporâneo, cit., p. 308.

${ }^{361}$ Código de Direito Internacional de Direitos Humanos anotado. Coord. Geral Flávia Piovesan. São Paulo: DPJ, 2008, p. 17.

${ }^{362}$ Idem, p. 1432.
} 
das pessoas, assegurado o direito à indenização pelo dano material ou moral decorrente de sua violação".

A menção do legislador à vida privada e à intimidade, em separado, suscita o debate sobre a distinção entre os conceitos, perante o ordenamento brasileiro.

$\mathrm{Na}$ lição de Manoel Gonçalves F. Filho, a intimidade inclui-se na vida privada, mas com ela não se confunde, consistindo em seu núcleo mais profundo, no qual se situam os sentimentos, escolhas sexuais e opções pessoais. A liberdade da vida íntima, destarte, compreende as escolhas de modo e projeto de vida, baseadas na consciência do indivíduo e que só lhe dizem respeito enquanto permanecem em sua esfera pessoal, sem refletir em relação aos outros. ${ }^{363}$

Na pesquisa etimológica de José Adércio Leite Sampaio, com base nas origens dos vocábulos intimus e privatus, a raiz da palavra intimidade remete a um conteúdo relacional de proximidade, confidência e amizade, enquanto a raiz de vida privada parece indicar algo isolado, distante e solitário. ${ }^{364} \mathrm{O}$ autor efetua pesquisa no Direito Comparado, apontando distinção entre a privacy e a intimacy no direito americano, incluindo na primeira o direito de tomar decisões fundamentais concernentes à própria pessoa e limitando a segunda à esfera das relações íntimas, notadamente sexuais. Já no direito europeu, de acordo com o mesmo autor, a privacidade e a intimidade estariam contidas no direito à vida privada, igualmente não havendo distinção relevante entre os conceitos de vida privada e intimidade nos países de língua espanhola e no Brasil. ${ }^{365}$

No sentido da inexistência de relevantes diferenças entre os conceitos, registre-se a conclusão de Victor Gabriel de Oliveira Rodrigues, em tese de doutoramento defendida pela Universidade de São Paulo, ao afirmar que a vida privada contém a intimidade, não apontando expressiva distinção entre um e outro. ${ }^{366}$

$$
\text { Esse entendimento acabou encampado no Código Civil }
$$
brasileiro, que alude apenas à vida privada, sem qualquer menção à intimidade. Na dicção

\footnotetext{
${ }^{363}$ FERREIRA FILHO, Manoel Gonçalves. Aspectos de direito constitucional contemporâneo, cit., p. $310 / 311$.

${ }^{364}$ SAMPAIO, José Adércio Leite. Direito à Intimidade e à Vida Privada: uma visão jurídica da sexualidade, da família, da comunicação e informações pessoais, da vida e da morte. Minas Gerais: Del Rey, 1998, p. 268.

365 Idem, p. 270/273.

${ }^{366}$ Victor Gabriel de Oliveira Rodriguez, Tutela Penal da intimidade (tese de doutoramento apresentada à Faculdade de Direito da USP, 2007, p. 25 e segs. Apud Dallari, Sueli Gandolfi. A proteção do Direito à intimidade, a Confidencialidade e o Sigilo na Pesquisa em Saúde. In Benevides, Maria Victoria de Mesquita, Bercovici, Gilberto, Melo, Claudinei. Direitos Humanos , Democracia e República: Homenagem a Fábio Konder Comparato - São Paulo: Quartier Latin, 2009, p. 913.
} 
do art. 21: "A vida privada da pessoa natural é inviolável, e o juiz, a requerimento do interessado, adotará as providências necessárias para impedir ou fazer cessar ato contrário a esta norma".

Nesse contexto, a conclusão a que se chega é que a intimidade, autonomamente tutelada pela Constituição, no Código Civil encontra proteção sob o manto da vida privada, reconhecendo-se que o ordenamento assegura a tutela do núcleo íntimo pessoal de cada um, ora sob a denominação de intimidade, ora de vida privada, neste trabalho utilizadas como sinônimos.

Adriano De Cupis relaciona o tema da intimidade com o direito ao resguardo e o direito ao segredo. Segundo o autor: "Resguardo pode definir-se como modo de ser da pessoa que consiste na exclusão do conhecimento pelos outros daquilo que se refere a ela só". ${ }^{367} \mathrm{O}$ direito ao segredo, por sua vez, é associado pelo autor à tutela da liberdade, de modo a assegurar ao sujeito "o livre desenvolvimento da actividade pessoal entre as paredes domésticas, a plena independência dos que ali habitam perante os que não têm o direito de aí entrar". ${ }^{368}$ A menção à habitação ou às "paredes domésticas", explica o autor, não implica uma interpretação literal. Como define De Cupis: "Segredo doméstico é precisamente, não o segredo daquela res que seria a casa, mas sim uma forma de segredo pessoal, isto é, das atitudes íntimas da pessoa assumidas na sua habitação". 369

Nesse contexto, dois aspectos relevantes e complementares emergem na composição do direito à intimidade: a permissão para realizar escolhas íntimas com liberdade e o resguardo da publicidade para garantir a independência em relação à opinião dos outros, por ocasião da tomada de decisão.

A complementaridade entre o direito à intimidade e o sigilo fica clara na análise da trajetória do conceito de privacidade que Maria Celina Bodin de Moraes realiza, com apoio em Stefano Rodotà: "da originária definição - the right to be let alone ao direito de determinar as modalidades de construção da própria esfera privada, bem como ao direito de manter o controle sobre as próprias informações". 370

O direito à intimidade, pode-se, então, afirmar, possui uma dimensão de segredo, no pressuposto de que o resguardo da opinião pública é necessário para permitir o exercício pleno da liberdade na vida privada. Nesse sentido, a lição do

\footnotetext{
${ }^{367}$ DE CUPIS, Adriano. $O$ direito ao resguardo. In Os direitos da personalidade. Tradução de Adriano Vera Jardim e António Miguel Caeiro. Lisboa: Livraria Morais Editora, 1961, p. 129.

${ }^{368}$ DE CUPIS, Adriano. O direito ao segredo. In Os direitos da personalidade, cit., p. 163.

${ }^{369}$ Idem, mesma página.

${ }^{370}$ MORAES, Maria Celina Bodin de. Na medida da pessoa humana: estudos de direito civil, cit., p. 141.
} 
professor Manoel Gonçalves Ferreira Filho ao salientar a importância do segredo para a tutela da intimidade, afirmando que o direito ao segredo da vida íntima é complementar ao direito à intimidade, pois sem esse resguardo "as pressões sociais poderiam reduzir a nada o direito de seguir as próprias preferências íntimas". ${ }^{371}$

Celso Lafer, forte na lição de Hannah Arendt, aprofunda o tema da intimidade como uma descoberta positiva moderna, pela qual se permite o diálogo consigo mesmo, o pensamento e a vita activa ${ }^{372}$ Lafer identifica no pensamento cristão a origem do valor da intimidade, baseado no anonimato da caridade, enfatizando o conteúdo diverso assumido na modernidade, pelo qual a intimidade se coloca como reação ao conformismo nivelador da sociedade. ${ }^{373}$ Ressalta a relevância da intimidade para a dignidade humana, na medida em que permite a expansão da personalidade individual de cada um, assegurando ao indivíduo sua identidade diante dos riscos de massificação social. ${ }^{374}$ Isso porque a esfera da intimidade, de acordo com a leitura que Celso Lafer aprofunda sobre Hannah Arendt, rege-se pelo princípio da exclusividade, que garante a cada um a singularidade inerente à condição humana. Por definição, tal princípio implica escolhas pessoais guiadas pela essência da pessoa sob o enfoque da "diferença em relação a todas as pessoas que conhecemos" e não com base em "nenhum padrão objetivo ou normas". 375

Diante do exposto, cabe encerrar este item com a síntese de Stefano Rodotà, baseado em L. M. Frideman e F. Rigaux. Nas palavras do autor: "a privacidade pode ser identificada com 'a tutela das escolhas de vida contra toda forma de controle público e de estigmatização social', em um quadro caracterizado justamente pela 'liberdade das escolhas existenciais'”, 376

\section{6.b) O direito à vida privada em proteção do transexual}

Assentada a relevância da intimidade para a pessoa, de rigor indagar o conteúdo ou os bens que nela se incluem, com vistas a estabelecer a proteção do transexual com base no direito à vida privada.

\footnotetext{
371 FERREIRA FILHO, Manoel Gonçalves. Aspectos de direito constitucional contemporâneo, cit., p. 312.

${ }^{372}$ LAFER, Celso. A reconstrução dos direitos humanos, cit., p. 239

${ }^{373}$ Idem, p. 263.

${ }^{374}$ Idem, p. 267.

375 Idem, p. 268.

${ }^{376}$ A vida na sociedade da vigilância - a privacidade hoje. Organização, seleção e apresentação de Maria Celina Bodin de Moraes. Tradução de Danilo Doneda e Luciana Cabral Doneda. Rio de Janeiro: Renovar, 2008, p. 92/93.
} 
Sintetiza Celso Lafer que o direito à intimidade, integrante dos direitos da personalidade, tutela "o direito do indivíduo de estar só e a possibilidade que deve ter toda pessoa de excluir do conhecimento de terceiros aquilo que a ela só se refere, e que diz respeito ao seu modo de ser no âmbito da vida privada". 377

Miguel Ángel Presno Linera traz conceito desenvolvido pela Corte Europeia de Direitos Humanos, em 29/04/2002, no caso Pretty c. Reino Unido, segundo o qual: “a 'vida privada' é uma noção ampla que engloba, entre outras coisas, aspectos da identidade física e social de uma pessoa, o direito de autodeterminação, o direito ao desenvolvimento da personalidade e o direito de estabelecer e manter relações com outros seres humanos e o mundo exterior" (tradução livre). ${ }^{378}$

Diante da multiplicidade de bens incluídos na noção de intimidade, afigura-se inviável definir de antemão o conteúdo do direito à vida privada, que corresponde a uma cláusula aberta e, por isso, é passível de diferentes interpretações.

Nas palavras de José Adércio Leite Sampaio ao discorrer sobre a abertura do conceito, "quer-se dizer que seu conteúdo é dinâmico, como dinâmica é a vida e mutável, como mutável é a compreensão humana de si mesmo e de seu devir", 379

No âmbito do sistema europeu dos direitos humanos, outrossim, a interpretação do direito à vida privada e familiar é analisada por Susana Almeida. Constata a autora em dissertação de mestrado, uma interpretação "dinâmica e evolutiva" do art. $8^{\circ}$, da Convenção, que vai adaptando o significado da vida familiar e privada aos padrões socioculturais e às condições de vida vigentes, concluindo: “é justamente no âmbito do art. $8^{\circ}$ que este dinamismo interpretativo do TEDH tem tido as expressões mais criativas". 380

O processo de definição dos contornos deste direito pela jurisprudência fica claro no exemplo de Eduardo Appio. De acordo com o autor, a Suprema Corte Americana tem expandido o direito à privacidade ao tratar dos direitos reprodutivos, relacionando-o à dignidade e autonomia, como verificado no caso Planned

\footnotetext{
${ }^{377}$ LAFER, Celso. A reconstrução dos direitos humanos, cit., p. 239.

378 'la 'vida privada' es una noción amplia que engloba, entre otras cosas, aspectos de la identidad física y social de una persona, concretamente el derecho a la autodeterminación, el derecho al desarrollo personal y el derecho al establecer y mantener relaciones con otros seres humanos y el mundo exterior". In El concepto inclusivo de familia como principio emancipatorio de la vida social. Revista da AJURIS Associação dos Juízes do Rio Grande do Sul. Ano 38, n. 122 (jun. 2011). Porto Alegre: AJURIS, 2011.

379 SAMPAIO, José Adércio Leite. Direito à Intimidade e à Vida Privada: uma visão jurídica da sexualidade, da família, da comunicação e informações pessoais, da vida e da morte, cit., p. 274.

${ }^{380}$ ALMEIDA, Suzana. O respeito pela vida (privada e) familiar na jurisprudência do tribunal europeu dos direitos do homem: a tutela das novas formas de família. Coimbra: Coimbra Editora, 2008, p. 66.
} 
Parenthood v. Casey (1992). Nesse caso, a Suprema Corte, ao decidir pelo direito ao aborto antes da viabilidade do feto, enfatizou que o direito à privacidade envolve "escolhas centrais para a dignidade pessoal e autonomia", reconhecendo "o direito de definir seu próprio conceito de existência, fé, significado do universo e do mistério da vida humana". 381

Esse o contexto em que se situa a proteção dos transexuais sob o manto do direito à vida privada.

De fato, em que pese a inviabilidade de definição rígida ou do esgotamento dos temas que se inserem no âmbito da vida privada, possível constatar que o direito de configurar a aparência e atuar de acordo com o papel de determinado gênero, na definição dos contornos da própria vida, insere-se entre seus conteúdos.

Stefano Rodotà, especificamente ao tratar do direito à vida privada como fundamento para a proteção dos transexuais, sustenta uma ideia de vida privada mais ampla do que o direito ao segredo dos dados biológicos, incluindo a proteção das escolhas de vida, contra o controle público e a estigmatização social. Refere-se à decisão da Corte Europeia dos Direitos Humanos, em demanda contra a França, na qual o juiz Walsh tratou da intimidade, aludindo ao estilo de vida escolhido. Para Rodotà, o uso da palavra "escolhido" ("choisi") denota um sentido de vida privada como uma construção voluntária, não se podendo mais considerá-la como um dado, mas como uma construção, pela intervenção direta do interessado. ${ }^{382}$ Por isso, prefere o uso da expressão esfera privada, no lugar de vida privada, compreendida como o resultado da interação entre o privado e o social, que contribui para a definição de identidade pessoal, a partir da qual se define a identidade sexual. ${ }^{383}$

Percebe-se, assim, que a identificação com o sexo oposto inserese no âmbito da vida privada e resulta da dinâmica da vida. Nessa medida, liga-se ao livre

\footnotetext{
${ }^{381}$ APPIO, Eduardo. Direito das minorias. São Paulo: Editora RT, 2008, nota 81, p. 254.

382 Préséntation Générale des problèmes liés au transsexualisme. In Transsexualisme, médicine e droit. Actes XXIII Colloque de droit européen. Vrije Universiteit Amsterdam (Pays-Bas) 14-16 avril, 1993, p. 23. Disponível em: <books.google.com.br/books?id=5_ludHUsNAC\&printsec $=$ frontcovepage $\& q=$ Transsexualisme $\% 2 C \% 20$ médicine $\% 20$ et $\% 20$ droit\&f=true $>, \quad$ p. $\quad 17-24$ último acesso em 16/12/2011.

383 "Plutôt que de vie privée, je préfère donc parler d'une sphère privée qui est construite avec la contribution directe de l'intervention continue de l'intéressé, c'est le résultat d'une interaction entre le privé et le social et qui donne une contribution importante à la définition même de l'identité personnelle et par conséquent à la partie de l'identité personnelle qu'on peut définir comme identité sexuelle. RODOTÁ, Stefano. Préséntation Générale des problèmes liés au transsexualisme”. In Transsexualisme, médicine e droit, $\quad$ p. 24. Disponível em: <books.google.com.br/books?id=5_ludHUsNAC\&printsec $=$ frontcovepage $\& q=$ Transsexualisme $\% 2 C \% 20$ médicine $\% 20$ et $\% 20$ droit\&f=true $>$, p. $17 /$ último acesso em 16/12/2011.
} 
desenvolvimento da pessoa e à expansão da personalidade, pressupondo uma esfera de não impedimento e, portanto, de autonomia para definir os próprios projetos de vida, alcançada pela tutela da vida privada. O direito à intimidade, outrossim, garante o segredo da informação, o que permite uma maior liberdade de escolha.

Daí se afirmar que o direito à vida privada num ordenamento expressamente orientado pelo princípio da dignidade da pessoa humana desafia uma ampla compreensão, assentada na autonomia e no livre desenvolvimento da personalidade. ${ }^{384}$

\section{6.c) $O$ direito ao livre desenvolvimento da personalidade} como direito autônomo

O direito ao livre desenvolvimento da personalidade constitui um dos fundamentos da ordem espanhola, como se verifica no art 10, da Constituição daquele país: "A dignidade da pessoa, os direitos invioláveis que lhe são inerentes, o livre desenvolvimento da personalidade, o respeito à lei e aos direitos dos demais são fundamento da ordem política e da paz social" (tradução livre). ${ }^{385}$

Na América Latina, o art. $2^{\circ}, 1$, da Constituição e o art. $5^{\circ}$, do Código Civil, do Peru, consagram situação jurídica subjetiva atintente à liberdade pessoal, ou, nos termos da Constituição, ao livre desenvolvimento da personalidade. ${ }^{386}$

O art. 2º da Constituição da República Italiana, de 1948, também alude ao desenvolvimento da personalidade, ${ }^{387}$ vislumbrando-se o reconhecimento expresso dessa dimensão da dignidade humana no direito alienígena.

No Brasil, em que pese a omissão no ordenamento positivo, admite-se a existência do direito ao livre desenvolvimento da personalidade naquilo que permite ao indivíduo fazer opções íntimas e dirigir a própria vida em direção à autorrealização, corolário da dignidade protegida nos planos nacional e internacional. Nesse sentido, aponta André de Carvalho Ramos para a não-tipicidade e constante

\footnotetext{
${ }^{384}$ SAMPAIO, José Adércio Leite. Direito à Intimidade e à Vida Privada: uma visão jurídica da sexualidade, da família, da comunicação e informações pessoais, da vida e da morte. Minas Gerais: Del Rey, 1998, p. 274.

385 "La dignidad de la persona, los derechos inviolales que le son inherentes, el libre desarrollo de la personalidad, el respeto a la ley y a los derechos de los demás son fundamento del orden político y de la paz social."

${ }^{386}$ SESSAREGO, Carlos Fernández. El cambio de sexo y su incidencia en las relaciones familiares. Revista de Direito Civil, Imobiliário, Agrário e Empresarial. Ano 15 - vol 56. São Paulo: RT, abril-junho 1991, p. 22.

387 Art. 2. La Repubblica riconosce e garantisce $i$ diritti inviolabili dell'uomo, sia come singolo sia nelle formazioni sociali, ove si svolge la sua personalità, e richiede l'adempimento dei doveri inderogabili di solidarietà politica, economica e sociale.
} 
alargamento do rol dos direitos fundamentais, com base em seu conteúdo, qual seja a dignidade da pessoa humana. Afirma que o princípio da dignidade é protegido de um ponto de vista ético-valorativo e concretiza-se historicamente, acrescentando que as margens móveis do conceito de direitos humanos explicam a eficácia irradiante dos direitos fundamentais. $^{388}$

A relação entre a dignidade, os direitos humanos e o desenvolvimento da personalidade fica clara na citação de Guilherme Assis de Almeida, ao indagar: "Garantida a dignidade humana por meio da não-violação de seus direitos humanos mais essenciais, o que pode o ser humano fazer, daí em diante? O homem e a mulher, caso queiram, podem desenvolver-se". 389

A partir daí, autorizado admitir o direito ao livre desenvolvimento da personalidade como desdobramento e irradiação do princípio da dignidade da pessoa humana assegurado no ordenamento jurídico.

No Brasil, o direito ao livre desenvolvimento da personalidade encontra fundamento também no direito à vida privada, presente no art. $5^{\circ}, \mathrm{X}$, da Constituição e no art. 21, do Código Civil, na medida em que um dos objetivos da proteção da intimidade, como visto, é garantir ao sujeito uma esfera de liberdade, na qual as escolhas não precisem ser justificadas a ninguém e, portanto, atendam exclusivamente ao interesse do titular do direito, em prol de seu desenvolvimento e autorrealização.

Do direito infraconstitucional também são extraídos outros elementos que autorizam o reconhecimento do direito ao livre desenvolvimento da personalidade, a partir do Código Civil, cujo art $2^{\circ}$ põe a salvo a personalidade do nascituro, enquanto o art. 11 determina a impossibilidade de limitação voluntária dos direitos da personalidade.

Diante do exposto, admite-se a existência do direito ao livre desenvolvimento da personalidade no ordenamento jurídico brasileiro, com base na Constituição Federal e na aplicação da cláusula geral de tutela da pessoa consubstanciada no princípio da dignidade humana, como desdobramento dos direitos à intimidade e à vida privada, ou como aplicação das garantias existentes aos direitos da personalidade no Código Civil.

\footnotetext{
${ }^{388}$ RAMOS, André de Carvalho. Processo Internacional dos Direitos Humanos: análise dos sistemas de apuração de violações de direitos humanos e implementação das decisões no Brasil. Rio de Janeiro: Renovar, 2002, p. 13.

${ }^{389}$ Direitos Humanos e não-violência. São Paulo: Atlas, 2001, p. 165/166.
} 
Resta, então, aprofundar o conteúdo do referido direito e analisar sua relação com o tema da transexualidade que se está a desenvolver.

\section{6.d) Os conteúdos do direito ao livre desenvolvimento da}

personalidade

$\mathrm{Na}$ lição de Capelo de Souza, a personalidade humana é composta por duas organizações: a somático-psíquica e a funcional ou relacional. A primeira inclui bens ou elementos constitutivos (ex: vida, corpo e espírito), funções (ex: circulatória e inteligência), estados (p. ex. a saúde, o prazer e a tranquilidade), e forças, potencialidades e capacidades (os instintos, os sentimentos, a inteligência, a vontade, a fé, a capacidade de trabalho, o poder de iniciativa etc...); e a segunda estrutura, denominada funcional ou relacional, refere-se ao ser socioambientalmente inserido e fixa-se entre dois polos de interação: o eu e o mundo, este considerado tanto o mundo interno quanto o mundo exterior ou o conjunto das forças ambientais em que se situa cada indivíduo. ${ }^{390}$

Essa complexa estrutura composta por elementos físicobiológicos, psíquicos e relacionais está em constante transformação, cabendo ao Direito, como sistema normativo que fixa na pessoa humana o objeto máximo de tutela, a criação de normas que lhe assegurem proteção contínua e permanente no curso do processo vital.

Nessa esteira, a positivação do princípio da dignidade da pessoa humana e os direitos da personalidade correspondem à resposta jurídica primeira e imediata, na salvaguarda dos mais elementares bens humanos, como a vida, o corpo, a identidade, a personalidade e o nome, entre outros, ${ }^{391}$ cuja efetividade depende de sua adaptação à mutabilidade inerente à vida. Assim, o livre desenvolvimento da personalidade envolve uma projeção para o futuro, considerando que a vida da pessoa, cuja personalidade se protege, está em constante mutação.

Bem por isso, afirma Capelo de Sousa que o bem jurídico tutelado por meio dos direitos da personalidade no direito civil, qual seja a personalidade humana, não é estático e inclui elementos dinâmicos, que interagem no tempo. Disso resulta a concepção do autor de direito ao desenvolvimento da personalidade, na

\footnotetext{
${ }^{390}$ CAPELO DE SOUSA, Rabindranath Valentino Aleixo. O direito geral de personalidade. Coimbra: Coimbra Editora, 1995, p. 199/200.

${ }^{391}$ Segundo Adriano De Cupis, os direitos da personalidade e os respectivos bens que lhe correspondem, ocupantes de hierarquia superior em relação aos demais, referem-se à vida, à integridade física, à liberdade, à honra, ao resguardo, à identidade e à paternidade intelectual. in Estrutura dos Direitos da Personalidade, p. 22/23, in Os direitos da personalidade. Tradução de Adriano Vera Jardim e António Miguel Caeiro. Lisboa: Livraria Morais Editora, 1961, p. 13/31.
} 
perspectiva de que não só a essência, como também a existência do homem merece idêntica proteção legal. ${ }^{392}$ A acepção de direito ao desenvolvimento da personalidade inclui, portanto, a tutela da liberdade da pessoa em ação, o que explica o caráter dinâmico do direito.

Anota Jorge Miranda que o direito ao livre desenvolvimento da personalidade não integra o núcleo dos direitos da personalidade, para ele composto dos direitos à vida, à integridade pessoal, à identidade individual, à capacidade civil, à cidadania, ao bom nome e reputação, à imagem, à palavra, à reserva da intimidade da vida privada e familiar e à identidade genética. O direito ao livre desenvolvimento da personalidade, diversamente, é pelo autor incluído entre os direitos de liberdade, tendo por conteúdo o direito positivo de agir e o direito negativo de não sofrer o sujeito interferência ou impedimento. ${ }^{393}$

Percebe-se, destarte, a ênfase que se dá à liberdade de agir, fazer ou não fazer, entre os bens da personalidade ao lado dos elementos estáticos, resultando na tutela da pessoa em movimento e interação. Trata-se da liberdade aplicada ao indivíduo, assegurando o direito de escolha na conformação da personalidade.

Assinala Alexy que a perspectiva negativa do direito de liberdade ganhou contornos amplos, por meio da interpretação do direito ao livre desenvolvimento da personalidade previsto no art. $2^{\circ}, \S 1^{\circ}$, da Lei Fundamental Alemã. Segundo o autor, o Tribunal Constitucional Federal decidiu pela existência de um direito fundamental autônomo à liberdade geral de ação, garantidor da liberdade de se fazer ou deixar de fazer o que se quer, estendido à ação e à proteção de situações e posições jurídicas do titular de direitos fundamentais, ${ }^{394}$ a partir do que, afirma Alexy, o direito de liberdade não protege apenas o "fazer" da pessoa, mas também o seu "ser" fático e jurídico. ${ }^{395}$

\section{6.e) O livre desenvolvimento da personalidade e a}

\section{transexualidade}

Capelo de Sousa, ao descrever os conteúdos do bem jurídico inerente a todo ser humano vivo, afirma que a proteção dos direitos da personalidade visa a assegurar "a possibilidade de emergência das forças energéticas e transformadoras,

\footnotetext{
${ }^{392}$ CAPELO DE SOUSA, Rabindranath Valentino Aleixo. O direito geral de personalidade, cit., p. 117.

${ }^{393}$ MIRANDA, Jorge. Manual de Direito Constitucional. Tomo IV, cit., p. 91.

${ }^{394}$ ALEXY, Robert. Teoria dos Direitos Fundamentais, cit., p. 341/345.

${ }^{395}$ Idem, p. 344.
} 
interiores de cada homem; a garantia de meios e condições existenciais e convivenciais, tanto naturais como sociais, suficientes para todo homem se poder desenvolver e a salvaguarda do poder de autodeterminação de cada homem e de auto-constituição de sua personalidade individual". 396

Assevera o autor que "no desenvolvimento da personalidade de cada homem releva, outrossim, o poder de autodeterminação de seu titular", 397 exercido por meio da "possibilidade de contestação e de ruptura com os sistemas informativos e comportamentais externos", e "sobretudo na automodelação do carácter, do temperamento, do intelecto e do corpo e na adaptação sócio-ambiental, numa dinâmica de autoconstituição ou de autodesenvolvimento da personalidade individual". 398

Na lição do jurista português, o direito ao desenvolvimento da personalidade envolve uma ampliada autonomia, pelo autor referida como poder de autodeterminação, estendida à conformação do caráter e do corpo, reconhecendo-se ao sujeito a possibilidade de singularizar-se e individualizar-se, nos limites permitidos pelo ordenamento.

Aponta Capelo de Souza as seguintes causas de limitação: os direitos da personalidade dos outros membros da coletividade, quais sejam: a vida, a integridade física, a identidade e a honra; os bens jurídicos ambientais e sociais; e a própria dignidade humana, diante dos quais deve ceder o direito individual ao desenvolvimento da personalidade. $^{399}$

A qualificação dos direitos da personalidade como bens indisponíveis, insuscetíveis de alienação ou renúncia, salvo nos casos previstos em lei, ${ }^{400}$ e a assunção de que são irrenunciáveis, não podendo seu exercício sofrer limitação voluntária, $^{401}$ igualmente resultam em restrições ao exercício da autonomia na configuração da própria personalidade.

Sob esse aspecto, cabe lembrar que a doutrina reconhece uma maior amplitude de exercício da autonomia em relação aos direitos fundamentais.

Ressalta Ricardo Lorenzetti que, enquanto a autonomia nos contratos vem sendo restringida pelas normas regulatórias, "nas questões extrapatrimoniais, produz-se o processo contrário, afirmando-se o individualismo contra

\footnotetext{
${ }^{396}$ CAPELO DE SOUSA, Rabindranath Valentino Aleixo. O direito geral de personalidade, cit. , p. 353.

${ }^{397}$ Idem, p. 356.

${ }^{398}$ Idem, p. 357.

399 Idem, p. 358/359.

${ }^{400}$ AMARAL, Francisco, Direito Civil, cit., p. 286.

${ }^{401}$ GOMES, Orlando. Introdução ao Direito Civil, cit., p. 137.
} 
toda forma de limitação, como ocorre, por exemplo, no que se refere à disponibilidade de direitos sobre o corpo". 402

Tal noção diferenciada de autonomia, em comparação com aquela própria das relações patrimoniais, resulta do princípio da dignidade da pessoa humana, assegurando a mais ampla liberdade possível nas relações não patrimoniais, de caráter existencial, na medida em que se reconhece a essencialidade desses direitos para a vida humana com dignidade. ${ }^{403}$

Na lição de Capelo de Souza: “Ou seja, embora os poderes jurídicos integrantes da tutela geral da personalidade estejam em princípio fora do comércio e sejam indisponíveis nas relações com os outros seres, tal não impede que na esfera pessoal de cada indivíduo se verifiquem mutações juridicamente tuteladas emergentes do poder de autodeterminação do homem". 404

O civilista português inclui no direito ao livre desenvolvimento da personalidade a liberdade para dirimir os próprios conflitos e assumir as finalidades próprias em um processo dinâmico, nos pressupostos de que a personalidade é mutante e o homem uma unidade que vai criando a si mesma, exemplificando, entre as mutações passíveis de respeito universal a configuração sexo-corporal. ${ }^{405}$

Sessarego sintetiza os argumentos a favor e contra a mudança de sexo, sob o enfoque do livre desenvolvimento da personalidade. Para a posição doutrinária favorável, a liberdade de escolha de projeto de vida, voltada à realização plena da pessoa, inclui a "possibilidade de viver de acordo com o sexo que responde às profundas inclinações sociológicas da pessoa, a seus costumes, hábitos, reflexos, atitudes, estilo. É dizer, o direito a realizar-se como pessoa de acordo com aquele gênero, oposto ao sexo originário e registral, ao qual o sujeito está 'convencido' de pertencer, que sente profundamente, radicalmente" (tradução livre). ${ }^{406}$ Diversamente, para a posição contrária,

\footnotetext{
${ }^{402}$ LORENZETTI, Ricardo Luis. Fundamentos do Direito Privado, cit., p. 502.

${ }^{403}$ MORAES, Maria Celina Bodin de. Uma aplicação do princípio da liberdade. In Na medida da pessoa humana. Rio de Janeiro: Renovar, 2010, p. 190.

${ }^{404}$ CAPELO DE SOUSA, Rabindranath Valentino Aleixo. O direito geral de personalidade, cit., p. 407. ${ }^{405}$ Idem, p. 406/407.

406 "la posibilidad de vivir de acuerdo con el sexo que responde a las profundas inclinaciones sicológicas de la persona, a sus costumbres, hábitos, reflejos, actitudes, estilo. Es decir, el derecho a realizarse como persona dentro de aquel gênero, opuesto a su sexo originario y registral, al cual el sujeto está 'convencido' de pertencer, que siente hondamente, raigalmente”. in SESSAREGO, Carlos Fernández. El cambio de sexo y su incidencia en las relaciones familiares. Revista de Direito Civil, Imobiliário, Agrário e Empresarial. Ano 15 - vol 56. abril-junho 1991, p. 23.
} 
a mudança de sexo esbarraria na ordem pública, comprometendo a certeza e verdade do sexo anotado no registro civil, além de atentar contra os bons costumes. ${ }^{407}$

$\mathrm{Na}$ atualidade, à luz das mudanças sociais e culturais e dos avanços da técnica, tem prevalecido a primeira posição, como se demonstrará pela compilação da jurisprudência nacional e internacional no último capítulo, admitindo-se a realização da cirurgia e da alteração do estado civil em respeito ao transexual. Mesmo porque há uma percepção crescente de que à ordem pública interessa uma informação registral coerente com o modo pelo qual a pessoa é conhecida, adequada à sua aparência, para a efetiva tutela da segurança jurídica.

Acrescenta Sessarego que, no cotejo entre o direito à identidade sexual e a ordem pública, o juiz e o legislador devem ter presente, na busca do justo equilíbrio entre os interesses em jogo, que a sociedade e o Estado estão a serviço da pessoa, e não o contrário. ${ }^{408}$

Quanto aos bons costumes, importa anotar que a operação é realizada como forma de tratamento, inexistindo qualquer ofensa ao costume na salvaguarda da saúde de quem sofre. Os costumes, ademais, como valorações éticas de uma determinada sociedade, em certa época, estão em constante mutação, não parecendo exagerado afirmar que a mudança de sexo, no século XXI, ainda que cause perplexidade, não é sentida como uma grave ofensa moral.

Nesse sentido, admitia Capelo de Sousa, já em 1995, especificamente sobre a transexualidade, a existência do direito à conformação corporal de acordo com o sexo de identificação: "parece inegável reconhecer um certo poder de autodeterminação corporal, ao chamado transexual, não apenas na sua orientação sexual mas também na sua configuração sexo-corporal (v.g., crescimento de seios e aproximação do figurino feminino), quando dotado de vontade sã, livre e esclarecida". ${ }^{409}$

Amparava-se na jurisprudência alemã específica sobre a transexualidade, na explicitação do conteúdo do direito geral de personalidade, ao citar precedentes sobre a autodeterminação sexual e a esfera íntima, de 11.10.78 (BVerfGE 49, 286 e 297 e segs) e sobre a nova determinação da pertença sexual de transexuais e a mudança de prenome, de 16.3.82 (BVerfGE 60, 123). ${ }^{410}$

\footnotetext{
${ }^{407}$ SESSAREGO, Carlos Fernández. El cambio de sexo y su incidencia en las relaciones familiares, cit., p. 24.

${ }^{408}$ Idem, p. 30

${ }^{409}$ CAPELO DE SOUSA, Rabindranath Valentino Aleixo. O direito geral de personalidade, cit., p. 225.

${ }^{410}$ Idem, p. 142.
} 
Descaracterizada, então, a mudança de sexo decorrente da transexualidade como uma ofensa à ordem pública ou uma violação aos bons costumes, prevalece a liberdade pessoal no exercício do direito ao desenvolvimento da personalidade, em cujo curso ocorre a identificação de gênero.

Nessa esteira, a opção do transexual, por aparentar, assumir o papel e passar a viver como alguém que pertence ao sexo oposto, pode ser entendida como o exercício da autonomia em direção ao desenvolvimento da personalidade, que se expressa tanto na solução do conflito interno, quanto sob o aspecto da conformação corporal.

Diagnosticada a identificação com o gênero contrário ao físico, destarte, em proteção integral à dignidade humana, a melhor opção é aquela que reconhece civil e juridicamente o gênero de identificação da pessoa, no efetivo respeito à sua personalidade em desenvolvimento.

\section{C) A IGUALDADE}

\section{1) A situação dos transexuais: vítimas de discriminação por}

motivo de sexo

No item B, deste Capítulo III, o tema foi abordado sob o enfoque da liberdade e seus desdobramentos, como a autonomia, o direito à vida privada e ao desenvolvimento da personalidade, em busca de fundamentos para a proteção da pessoa transexual.

O direito à igualdade também contribui para o aperfeiçoamento dessa tutela, na medida em que, como ensina Caio Mario da Silva Pereira, "o princípio constitucional da igualdade perante a lei é a definição do conceito geral da personalidade como atributo natural da pessoa humana, sem distinção de sexo, de condição de desenvolvimento físico ou intelectual, sem gradação quanto à origem ou à procedência". 411

A lei é expressa quanto à garantia da igualdade e à proibição de discriminação por motivo de sexo, valendo investigar se tal proteção se estende também à identidade de gênero que caracteriza a transexualidade.

${ }^{411}$ PEREIRA, Caio Mario da Silva. Instituições de Direito Civil. vol I. $20^{\text {a }}$ ed. Rio de Janeiro: Forense, 2004, p. 240. 
Na lição de Flávia Piovesan, os direitos sexuais compreendem: o direito de decidir livre e responsavelmente sobre sua sexualidade; o direito de ter controle sobre o próprio corpo; o direito de viver sua orientação sexual sem sofrer discriminação; o direito a receber educação sexual; o direito à privacidade; o direito de acesso às informações e aos meios para usufruir alto padrão de saúde sexual; e o direito de fruir do progresso científico e a consentir livremente à experimentação, com os devidos cuidados éticos recomendados pelos instrumentos internacionais. ${ }^{412}$

Nesses termos, diante da amplitude dos direitos sexuais, pode-se afirmar que a questão da transexualidade, ao mesmo tempo que envolve um conflito de identidade de gênero, entrelaça-se com o tema da sexualidade, ainda que não esteja diretamente ligada ao sexo ou à orientação sexual. De fato, embora a questão do transexual não seja propriamente de sexo, mas de gênero, a adoção da perspectiva de Henry Benjamin, que inclui o componente psicológico entre os elementos que definem o sexo, ${ }^{413}$ autoriza o mesmo raciocínio no que toca à vedação da discriminação. E, também em relação ao direito ao controle sobre o próprio corpo, ou à privacidade, insere-se a transexualidade na temática dos direitos sexuais.

O Tribunal de Justiça da União Europeia, na esteira do avanço progressivo para uma comunidade que respeite os princípios gerais da União e os direitos fundamentais por ela amplamente reconhecidos, igualmente tem contribuído para o combate à discriminação contra transexuais, inserido na temática do sexo. ${ }^{414}$ No Acórdão P. contra S. e Cornwall County Council, de 30 de abril de 1996 (proc. C-13/94), o Tribunal, instado a decidir sobre a irrelevância do sexo no que diz respeito às regras que regem relações sociais, diante da evolução do entendimento sobre a identidade sexual humana, entendeu que o direito fundamental a não ser discriminado tem "por finalidade aplicar-se às discriminações que têm a sua origem (...) na mudança de sexo". 415

$\mathrm{Na}$ interpretação dos relatores do Tribunal Europeu de Direitos Humanos ao julgar a Reclamação ${ }^{\circ} 28957 / 95$, referindo-se ao Acórdão $P$. contra $S$. $e$

\footnotetext{
${ }^{412}$ PIOVESAN, Flavia. A proteção dos direitos reprodutivos no direito internacional e no direito interno. In Temas de Direitos Humanos, p. 258.

${ }^{413}$ BENJAMIN, Henry, apud BENTO, Berenice. Da transexualidade oficial às transexualidades.In Piscitelli, Adriana e outros (org). Sexualidade e Saberes: convenções e fronteiras. Rio de Janeiro: Garamond, 2004, p. 159.

${ }^{414}$ LOPES, Dulce. Principais contributos da União Europeia e do Conselho da Europa em matéria de não deiscriminação. In Periódico do CIEDA e do CIEJD, em parceria com GPE, RCE e o CEIS20. $\mathrm{n}^{\circ} 4$ Janeiro/Junho 2011 - Semestral. ISSN 1647-6336. Disponível em: http://www.europe-directaveiro.aeva.eu/debatereuropa/, último acesso em 26/12/2011, p. 33.

${ }^{415}$ Idem, p. 42.
} 
Cornwall County Council, tal decisão da Corte de Justiça Europeia fixou o entendimento de que a discriminação decorrente da mudança de gênero equipara-se à discriminação com base no sexo ("discrimination on the ground of sex"). ${ }^{416}$

No caso KB contra National Health Services Pension Agency, de 07 de janeiro de 2004, o Tribunal de Justiça Europeu avançou mais na proteção à igualdade, ao considerar que a vedação do direito de casar aos transexuais gerava uma situação discriminatória. Embora o direito de casar não esteja incluído no leque de competências do direito comunitário, o caso foi conhecido e julgado, na consideração de que o casamento consiste em condição necessária para o gozo de determinados benefícios, como a pensão por viuvez. ${ }^{417}$

Roger Raupp Rios sustenta que a proibição de discriminação sexual inclui a proibição de discriminação por gênero, partindo da premissa de que o sexo se refere não somente a caracteres físicos das mulheres, mas também ao papel social e à imagem que lhes são atribuídos. Ou seja, percebido que muito da origem da discriminação por motivo de sexo não está fundada nos caracteres físicos sexuais da pessoa, mas, sim, no papel social por ela desempenhado, não há por que deixar de incluir a discriminação por identidade de gênero entre a discriminação em razão do sexo. Nesses termos, de rigor concluir com o autor que "tratamentos desfavoráveis decorrentes da chamada 'identidade de gênero' são hipóteses de discriminação por motivo de sexo". ${ }^{418}$

$\mathrm{O}$ autor fixa seu ponto de partida na ideia de que sexo e gênero devem ser considerados como realidades conjuntas e indissociáveis. Desse modo, a averiguação da existência ou não de discriminação deve abranger a análise do tratamento desfavorável tanto sob o aspecto do sexo, quanto do gênero, incluindo neste último a sexualidade e os papéis e representações sociais que lhe são próprios. Acrescenta Roger Rios que a discriminação, nessas hipóteses, é ainda mais grave, no pressuposto de que "sexualidade e gênero são dimensões fundamentais na construção da subjetividade e na configuração da vida social". 419

416 Cristine Goodwin v. Reino Unido, $\$ \S \quad 43, \quad 45 \quad$ e $92 . \quad$ Disponível em:<cmiskp.echr.coe.int/tkp197/view.asp?item=1\&portal=hbkm\&action0united\%20\%7C\%20kingdom\&sess ionid=81797137\&skin=hudoc-em>, acesso em novembro de 2011.

${ }^{417}$ LOPES, Dulce. Principais contributos da União Europeia e do Conselho da Europa em matéria de não deiscriminação. In Periódico do CIEDA e do CIEJD, em parceria com GPE, RCE e o CEIS20. $n^{\circ} 4$ Janeiro/Junho 2011 - Semestral. ISSN 1647-6336. Disponível em: http://www.europe-directaveiro.aeva.eu/debatereuropa/, último acesso em 26/12/2011, p. 42.

${ }^{418}$ Direito da Antidiscriminação, Sexo, Sexualidade e Gênero: a Compreensão da Proibição Constitucional de Discriminação por Motivo de Sexo, cit., 2008, p. 714.

${ }^{419}$ RIOS, Roger Raupp. Direito da Antidiscriminação, Sexo, Sexualidade e Gênero: a Compreensão da Proibição Constitucional de Discriminação por Motivo de Sexo, cit., p. 717. 
A defesa dos transexuais mediante a proibição de discriminação por motivo de sexo encontra respaldo na legislação canadense. De acordo com parecer da Comissão de Direitos Humanos de Ontário, a vedação à discriminação por identidade de gênero está inclusa na proibição de discriminação por motivo de sexo, valendo conferir: "pessoas que são discriminadas ou assediadas por identidade de gênero estão legalmente inclusas na proteção contra discriminação por motivo de sexo. Isso inclui transexuais, transgêneros, intersexos e cross-dressers, e outros, cuja identidade ou expressão de gênero seja, ou seja vista como, diferente do sexo de nascimento" (tradução livre). ${ }^{420}$

\section{2) Proposta de aplicação do princípio da igualdade para a}

\section{tutela dos transexuais}

A aplicação do princípio da igualdade contra a discriminação fundada no sexo está consolidada. Aponta Julieta Lemaitre Ripoll, ao analisar o papel da Corte Constitucional Colombiana na proteção dos direitos dos homossexuais, avanços a partir dos anos de 1990. No relato da autora, em 1998, a Corte reconheceu o direito à autodeterminação sexual do homossexual, fundamentado em dupla proteção: de um lado, o direito à igualdade; e de outro, o direito ao livre desenvolvimento da personalidade, resultando em um direito à identidade pessoal. ${ }^{421}$

No caso da sexualidade a regulação jurídica não é simples, já que estão ao mesmo tempo presentes exigências de proteção à intimidade da pessoa e de reconhecimento social, ocupando uma interface entre o público e o privado. Em outras palavras, enquanto o exercício dos direitos sexuais está no âmbito da privacidade e da liberdade, faz-se necessária a proteção estatal para que essa liberdade seja exercida sem discriminação, coerção e violência, ${ }^{422}$ tratando-se da dimensão pública que deve ser enfrentada com base no princípio da igualdade.

\footnotetext{
${ }^{420}$ Ontario Human Rights Comission. Ontario's Human Rights Code: $\left(\$ 2^{\circ}\right)$ : "People who are discriminated against or harassed because of gender identity are legally protected under the groun of sex. This includes transsexual, transgender and intersex persons, cross-dressers, and other people whose gender identity or expression is, or is seen to be, different from their birth-identified sex". Disponível em: www.ohrc.on.ca/en/issues/gender_identity, último em 26/12/2011.

${ }^{421}$ RIPOLL, Julieta Lemaitre. O amor em tempos de cólera: direitos LGBT na Colômbia, cit., p. 82.

${ }^{422}$ MATTAR, Laura Davis. Reconhecimento jurídico dos direitos sexuais - uma análise comparativa com os direitos reprodutivos. In SUR - Revista Internacional de Direitos Humanos, n. 8, disponível em www.surjournal.org/conteudos/getArtigo8.php?artigo=8,port,artigo_mattar.htm, acesso em 21/09/2011.
} 
Na precisa lição de Celso Lafer, em seu diálogo com o pensamento de Hannah Arendt: na esfera do privado prevalece a lei da diferença e da diferenciação, enquanto na esfera do público, o princípio da igualdade. ${ }^{423}$

Nessa quadra, releva aprofundar o tema da igualdade, no pressuposto de que, para a realização dos direitos humanos, não basta admitir a diferença sob o prisma da liberdade individual, fazendo-se necessário evitar que a diferença implique desigualdade perante a lei.

Nestas linhas, a proposta é refletir sobre o princípio da igualdade sob dois ângulos. Um primeiro relativo à violação da igualdade, que se vislumbra na estigmatização, na discriminação e na própria omissão legislativa. $\mathrm{O}$ segundo ângulo é propositivo, de investigação dos instrumentos disponíveis no ordenamento para, na ausência de lei específica, fomentar a inclusão pelo direito, por meio do reconhecimento do direito à identidade de gênero. Objetiva-se, assim, facilitar aos transexuais o acesso à vida pública, no reconhecimento efetivo de sua condição e dignidade humanas.

\section{3) O princípio da igualdade no direito positivo e sua leitura} sob o enfoque dos direitos humanos: a tutela da diferença

Fabio Konder Comparato aponta a Revolução Francesa como o momento histórico que desencadeou a supressão das desigualdades, identificando na igualdade o ponto central do movimento revolucionário, que "era, muito mais, a supressão das desigualdades estamentais do que a consagração das liberdades individuais para todos". ${ }^{424}$ Embora o movimento não tenha conseguido derrubar a barreira da desigualdade entre os sexos, reconhece-se seu caráter de resposta à humilhação das desigualdades sofridas tanto pelo povo humilde, quanto pela burguesia endinheirada, em relação aos privilégios do clero e da nobreza. ${ }^{425}$

Outros marcos significativos para o desenvolvimento do princípio da igualdade no constitucionalismo ocidental são o art. $6^{\circ}$, da Constituição belga, o $14^{\circ}$ Aditamento à Constituição dos Estados Unidos, o art. $4^{\circ}$, da Constituição Mexicana de 1917 , o art. $109^{\circ}$ da Constituição de Weimar e o art. $3^{\circ}$ da Constituição Italiana. ${ }^{426}$

\footnotetext{
${ }^{423}$ Reconstrução dos Direitos Humanos: um diálogo com o pensamento de Hannah Arendt, cit., p. $151 / 152$.

${ }^{424}$ A afirmação histórica dos direitos humanos. São Paulo: Saraiva, 2001, p.130.

${ }^{425}$ COMPARATO. Fabio Konder. A afirmação histórica dos direitos humanos. São Paulo: Saraiva, 2001, p.133.

${ }^{426}$ MIRANDA, Jorge. Manual de Direito Constitucional. Tomo IV, cit., p. 244.
} 
No enunciado do artigo primeiro da Declaração do Homem e do Cidadão, de 1789:

"Os homens nascem e permanecem livres e iguais em direitos. As distinções sociais só podem fundar-se na utilidade comum". ${ }^{427}$

Tratava-se, na origem da Declaração Francesa, da igualdade geral e abstrata e não individualizada, da igualdade formal necessária para permitir aos cidadãos o exercício de seus interesses privados, à época entendida como suficiente para a manutenção da ordem, ${ }^{428}$ consistindo abstração construída "pela ação conjunta dos homens através da organização da comunidade política". ${ }^{429}$

Em que pesem os limites dessa igualdade formal, não se ignora sua relevância, reconhecendo-se, com Alexy, que a igualdade jurídica é um valor em si mesma, de aplicação imediata e menos problemática do que a igualdade material, o que facilita sua concretização: "O princípio da igualdade jurídica - por estar ligado ao ato de tratamento em si e não ter de levar em consideração seus múltiplos efeitos - é mais simples e mais seguro em sua aplicação que o princípio da igualdade fática". 430

No primeiro momento, o enunciado da igualdade foi interpretado como um dever de igualdade na aplicação do direito, prevalecendo atualmente a concepção de que o princípio deve ser observado tanto na aplicação, quanto na criação do direito, vinculando todos os poderes do Estado. ${ }^{431}$ Na dicção de Celso Antônio Bandeira de Mello: "Entende-se, em concorde unanimidade, que o alcance do princípio não se restringe a nivelar os cidadãos diante da norma legal posta, mas que a própria lei não pode ser editada em desconformidade com a isonomia". 432

Daí porque se afirmar que a igualdade perante a lei não é igualdade exterior à lei, mas igualdade na lei, tendo por destinatários todos os órgãos de criação do Direito, ${ }^{433}$ incluindo os órgãos políticos e legislativos, os tribunais e os órgãos

\footnotetext{
427 Tradução de Fabio Konder Comparato. In A afirmação histórica dos direitos humanos. São Paulo: Saraiva, 2001, p.152.

428 BOITEUX, Elza Antonia Pereira Cunha. A constante axiológica dos direitos humanos. In Direitos Humanos, Democracia e República. Uma homenagem a Fábio Konder Comparato. São Paulo: Quartier Latin, 2009, p.382.

${ }^{429}$ LAFER, Celso. Reconstrução dos Direitos Humanos: um diálogo com o pensamento de Hannah Arendt, cit., p. 150.

${ }^{430}$ ALEXY. Robert. Teoria dos direitos fundamentais, cit., p. 418/419.

${ }^{431}$ Idem, p. 395.

${ }^{432} \mathrm{O}$ conteúdo jurídico do princípio da igualdade. $3^{\mathrm{a}}$ ed., $17^{\mathrm{a}}$ tiragem. São Paulo: Malheiros editora, 2009, p. 09.

${ }^{433}$ MIRANDA, Jorge. Manual de Direito Constitucional. Tomo IV, cit., p. 257.
} 
administrativos, ${ }^{434}$ acrescentando-se que as normas que vedam discriminação são de aplicação imediata, sem necessidade de lei interposta. ${ }^{435}$

A preocupação com a igualdade material somente nasceu no fim do século XVIII, com o surgimento do proletariado e suas respectivas reivindicações, impondo-se uma nova ética da igualdade, limitativa da ordem econômica e que se desenvolveu sob a perspectiva dos direitos sociais.

Atualmente se reconhece um direito geral de igualdade e direitos de igualdade específicos, ${ }^{436}$ cabendo aqui o aprofundamento do primeiro, inserido nas Constituições Modernas sob a fórmula do "todos são iguais perante a lei”.

De acordo com Jorge Miranda, o conteúdo do princípio da igualdade pode ser resumido em três premissas acolhidas quase unanimemente pela doutrina e jurisprudência: 1) a igualdade não significa identidade, e igualdade jurídica não é igualdade natural; 2) a igualdade significa intenção de racionalidade e de justiça; 3) a igualdade insere-se num contexto global que inclui outros valores constitucionais. ${ }^{437}$

Ensina o constitucionalista português que o primeiro sentido da igualdade é negativo, correspondendo à vedação de privilégios e discriminações. Já no segundo sentido, positivo, igualdade implica o tratamento igual dos iguais e desigual dos desiguais, proporcionalmente. Por fim, acrescenta que o princípio da igualdade impõe o tratamento das situações não apenas como existem, mas também como devem existir, de modo a compreender a igualdade perante a lei como igualdade por meio da lei. ${ }^{438}$

Flávia Piovesan identifica, além das tradicionais concepções formal e material de igualdade, uma terceira vertente, igualmente denominada igualdade material, mas não mais no sentido de justiça social e distributiva. Trata-se da igualdade material harmonizada com as políticas específicas de direitos humanos, voltadas à proteção das vítimas preferenciais da exclusão. Nesse sentido, a terceira vertente da igualdade corresponde "ao ideal de justiça enquanto reconhecimento de identidades (igualdade orientada por critérios como gênero, orientação sexual, idade, raça e etnia)" ${ }^{439}$

Nessa esteira, visualiza Ricardo Lorenzetti, entre aqueles que denomina direitos de quarta geração, o direito de ser diferente, surgido "de um processo de

\footnotetext{
${ }^{434}$ Idem, p. 261.

${ }^{435}$ Idem, p. 264/265.

${ }^{436}$ ALEXY. Robert. Teoria dos direitos fundamentais, cit., p. 393.

${ }^{437}$ MIRANDA, Jorge. Manual de Direito Constitucional, cit., p. 253.

${ }^{438}$ Idem, p. 253/256.

${ }^{439}$ Direitos Humanos e Justiça Internacional. São Paulo: Saraiva, 2011, p. 57.
} 
diferenciação de um indivíduo em relação ao outro". ${ }^{440}$ Expressamente inclui a mudança de sexo como derivação da liberdade, englobando-a entre os direitos rotulados de "direito de ser diferente". ${ }^{441}$

A terceira concepção de igualdade, na lição de Piovesan, integra a essência dos direitos humanos em sua dupla vocação: proteção da dignidade e prevenção do sofrimento. Em suas palavras: "A garantia da igualdade, da diferença e do reconhecimento de identidades é condição e pressuposto para o direito à autodeterminação, bem como para o direito ao pleno desenvolvimento das potencialidades humanas, transitando-se da igualdade abstrata e geral para um conceito plural de dignidades concretas". 442

É essa igualdade, baseada no reconhecimento, e não na abstração da diferença, que se pretende assegurar ao transexual.

Como alerta Joaquin Herrera Flores, o caráter abstrato do direito, derivado da ideia de que formalizar significa abstrair, pode implicar que a abstração da diferença resulte no aprofundamento da desigualdade, em nome de uma igualdade meramente formal e distante da real. ${ }^{443}$ Por isso, a necessidade da tutela do diferente, em sua singularidade, a fim de promover a justiça por meio da garantia de igualdade à identidade concreta da pessoa.

\section{4) A admissão do tratamento diferenciado em nome da} igualdade: a existência de razão suficiente (Robert Alexy) ou de correlação lógica e de fundamento constitucional que o justifique (Celso Antônio Bandeira de Mello)

Reconhece-se a desigualdade natural entre os homens, admitindo-se a conveniência das diferenças e, mais do que isso, a possibilidade do estabelecimento de tratamento diferenciado sem que isso implique qualquer ilegalidade. Na referência de Robert Alexy, o estabelecimento do serviço militar somente para adultos, de penas somente para criminosos, ou de maiores impostos para os mais ricos, são exemplos de tratamento diferente pelo legislador, à luz das diferentes posições fáticas

\footnotetext{
${ }^{440}$ LORENZETTI, Ricardo Luis. Teoria da Decisão Judicial. Fundamentos de Direito. Tradução de Bruno Miragem. Notas e revisão da tradução de Claudia Lima Marques. São Paulo: RT, 2009, p. 265.

${ }^{441}$ Idem, mesma página.

${ }^{442}$ PIOVESAN, Flavia. Direitos Humanos e Justiça Internacional, cit., p. 59.

${ }^{443}$ FLORES, Joaquín Herrera. La construcción De Las Garantías. Hacia Una Concepción Antipatriarcal De La Libertad Y La Igualdad. In Sarmento, Daniel, Ikawa, Daniela e Piovesan, Flavia. Igualdade, Diferença e Direitos Humanos, cit., p. 117.
} 
ocupadas pelas pessoas, que não violam o princípio da igualdade. ${ }^{444}$ Trata-se de hipóteses de diferenciação que resultam da natureza das coisas, como ser ex-aluno de determinada Universidade ou pertencer a uma determinada região, que podem ser definidas como critérios de admissão em determinada associação, sem qualquer ofensa à igualdade. ${ }^{445}$

O problema está, então, em definir qual característica releva para a aferição da igualdade e da desigualdade entre indivíduos e situações, na promoção ou vedação de tratamentos diferenciados, de modo a implementar a melhor forma de realização da igualdade. Sob o ponto de vista jurídico, destarte, admitido que as leis discriminam situações para submetê-las a tais ou quais regras, distinguindo seus efeitos com base em pontos de diferença identificados como relevantes, é preciso indagar, com Celso Antônio Bandeira de Mello, quais as discriminações juridicamente toleráveis. ${ }^{446}$

Nesse sentido, introduz Alexy o conceito de "razão suficiente", de presença necessária para justificar o tratamento desigual. Propõe que o conceito de razão suficiente seja interpretado em contraposição ao conceito de arbítrio. Assim afirma: "Uma razão é suficiente para a permissibilidade de um tratamento desigual se esse tratamento, em virtude dessa razão, deixa de ser arbitrário", ${ }^{447}$ identificando direitos de igualdade definitivos e abstratos, que consistem no direito de ser tratado igualmente, se não houver razão suficiente para permitir um tratamento desigual, e no direito de ser tratado desigualmente, se houver razão suficiente para o tratamento desigual. ${ }^{448}$

Tal razão suficiente, do modo como se compreende a questão, deve ser buscada no próprio ordenamento, materializada nos princípios que norteiam a interpretação de todo o sistema, essencialmente aqueles estabelecidos na Constituição. Daí se afirmar que somente é admitido tratamento desigual inspirado na concretização de valores constitucionais, sob pena de arbitrariedade. Ocorre que a expressão razão suficiente, como cláusula aberta, torna necessário acrescentar outros fundamentos, em auxílio do preenchimento de seu conteúdo.

Desde logo, assenta Bandeira de Mello que a investigação sobre eventual desacato ao princípio isonômico não deve se limitar à análise das pessoas, coisas ou situações envolvidas, admitindo-se lícitas discriminações por vários fatores, como o sexo, por exemplo, no caso da exigência do gênero feminino em concurso para

\footnotetext{
${ }^{444}$ ALEXY. Robert. Teoria dos direitos fundamentais, cit., p. 397.

${ }^{445}$ MIRANDA, Jorge. Manual de direito constitucional, cit., p. 265.

${ }^{446} \mathrm{O}$ conteúdo jurídico do princípio da igualdade, cit., p. 11.

${ }^{447}$ ALEXY. Robert. Teoria dos direitos fundamentais, cit., p. 413.

${ }^{448}$ Idem, p. 429.
} 
preenchimento de cargo da polícia feminina. ${ }^{449}$ Trata-se, isto sim, de investigar a correlação lógica entre a peculiaridade diferencial acolhida pelo legislador e o tratamento desigual estabelecido na lei, somado à exigência de que tal correlação se coadune com os interesses prestigiados pela Constituição. Ou seja, para que a desigualdade não importe quebra da isonomia é necessário que se analisem três aspectos da hipótese: o elemento tomado como fator de diferenciação; a correlação lógica abstrata entre o fator de discrímen e a desigualdade no tratamento jurídico; e a harmonia dessa correlação lógica com os valores positivados na Constituição. ${ }^{450}$

Importa destacar, assim, que não basta o argumento centrado na coerência racional própria da lógica para autorizar o tratamento discriminatório, exigindose que o tratamento desigual, para ser lícito, esteja de acordo com os princípios constitucionais. Como ressalta Celso Antônio Bandeira de Mello, para a tutela da isonomia: "não é suficiente o poder argüir-se fundamento racional, pois não é qualquer fundamento lógico que autoriza desequiparar, mas tão-só aquele que se orienta na linha de interesses prestigiados na ordenação jurídica máxima. Fora daí ocorrerá incompatibilidade com o preceito igualitário". 451

No mesmo sentido da aferição da igualdade sempre a partir da Constituição, o Parecer da Comissão Constitucional Portuguesa $n^{\circ} 32$, de 16 de setembro de 1982, trazido por Jorge Miranda: “O princípio da igualdade não funciona por forma geral e abstracta, mas perante situações ou termos de comparação que devam reputar-se concretamente iguais - e, antes de tudo, à luz de padrões valorativos ou da ordem axiológica constitucional". 452

A interpretação dos princípios constitucionais, afirma Celso Lafer, envolve tanto uma reflexão sobre o ângulo interno da norma e do ordenamento, quanto uma reflexão sobre o ângulo externo, correspondente aos fatos e valores que exigem ponderação. ${ }^{453}$ Refere Alexy, especificamente sobre o controle da igualdade, à necessidade de um juízo axiológico sobre a pertinência da característica escolhida como critério de diferenciação, no pressuposto de que não existe uma igualdade ou desigualdade absoluta em relação a todos os aspectos. ${ }^{454}$ De todo modo, para essa avaliação cabe

\footnotetext{
${ }^{449} \mathbf{O}$ conteúdo jurídico do princípio da igualdade, cit., p.17.

${ }^{450}$ Idem, p. $21 / 22$.

${ }^{451}$ Idem, p.43.

${ }^{452}$ MIRANDA, Jorge. Manual de Direito Constitucional, cit., p. 268.

${ }^{453}$ Filosofia do direito e princípios gerais. In $\mathbf{O}$ que é filosofia do direito. p 70.

${ }^{454}$ ALEXY. Robert. Teoria dos direitos fundamentais, cit., p. 400.
} 
lembrar que o enunciado geral da igualdade estabelece um ônus argumentativo para o tratamento desigual. ${ }^{455}$

Resta claro, assim, que a compatibilidade entre o tratamento diferenciado e a ordem constitucional é condição para autorizar qualquer distinção em nome da igualdade, sem embargo da dificuldade de proceder à avaliação dessa compatibilidade, na medida em que confluem valores e interesses plurais na Constituição, tornando necessária a atividade hermenêutica do intérprete.

De todo modo, assumida a diferença natural entre os homens, o princípio da igualdade, em regra, não autoriza o tratamento diferenciado baseado na constatação da diferença, visto que esta, repita-se, decorre da singularidade humana. A avaliação, então, da diferença autorizadora do tratamento desigual, não se baseia exclusivamente na realidade das coisas, mas envolve a reflexão sobre os valores constitucionais, de modo que somente seja autorizada a distinção de tratamento voltada à realização de valor preponderante no caso concreto.

Cumpre, então, analisar a licitude do tratamento diferenciado naquilo que nega o direito à identidade de gênero ao transexual, sob o enfoque do princípio da igualdade.

A identidade, como já afirmado, consiste em atributo inerente à condição humana, compartilhada por todos os Seres. Sem ela, seria difícil manter a consciência de si como sujeito, singularizando o indivíduo enquanto tal. Da essencialidade da identidade para a caracterização do Ser como pessoa, então, resulta a dificuldade de justificar a existência de razão suficiente para vedar a alguns o reconhecimento de sua identidade no plano jurídico, sem com isso incorrer na negativa da própria natureza humana da pessoa a quem a identidade é negada. Sequer a possibilidade de identificação pelo sexo biológico aproveita, considerando a dissonância entre esse elemento estático, de um lado, e a aparência e sentimento de pertença da pessoa, do outro. Daí se vislumbrar a arbitrariedade da distinção de tratamento, que nessa medida atenta contra o princípio da igualdade.

Dada a relevância do ponto, cumpre desenvolver melhor a ideia, por meio da aplicação dos critérios ensinados por Celso Antônio Bandeira de Mello à situação do transexual.

${ }^{455}$ Idem, p. 409. 
A licitude do tratamento desigual, como exposto, pressupõe a correlação lógica entre o fator de diferenciação e a desigualdade estabelecida, exigindo a compatibilidade do tratamento discriminatório com os valores máximos do ordenamento, positivados nos princípios constitucionais.

No caso, a desigualdade de tratamento consistente na vedação ao reconhecimento da identidade de gênero não guarda correlação lógica com o fator de diferenciação (identificação com o gênero contrário ao sexo), na medida em que o direito à identidade não é privativo de apenas alguns, no caso aqueles que se identificam com o papel socialmente condizente com o sexo biológico, tratando-se de atributo essencial da pessoa humana.

Nessa esteira, assumida a identidade como projeção imaterial da pessoa, integrante de sua personalidade, a negativa de reconhecimento jurídico da identidade do transexual acaba por resultar na limitação do gozo de direitos inerentes à condição de pessoa, sem fundamento lógico que a justifique, resultando na menor amplitude dos direitos da personalidade dos transexuais em relação àqueles que não o são, em violação ao princípio da igualdade.

De fato, a identidade, como visto no item I, está diretamente relacionada com o exercício da autonomia na definição do Ser moral. A tutela da identidade está assentada, assim, nos pilares do ordenamento, ou seja, nos princípios constitucionais inspiradores de toda construção jurídica, quais sejam a dignidade da pessoa humana, a liberdade e a vida privada, razão pela qual a negativa de reconhecimento da identidade atenta diretamente contra a Constituição.

Tudo indica, então, que a distinção de tratamento que subtrai da pessoa o direito de ser reconhecida como se sente e aparenta ser nega-lhe a autonomia que a caracteriza como ser humano, em violação de sua dignidade. Em outras palavras, impedir a pessoa de ter sua identidade sexual juridicamente tutelada aparentemente consiste em tratamento desigual despido de amparo constitucional, do que resulta discriminação indevida porque contrária aos valores da dignidade da pessoa humana, da liberdade e da vida privada, positivados na Constituição.

Por fim, cumpre consignar que não se postula a defesa da igualdade absoluta, admitindo-se hipóteses em que o tratamento desigual possa ser justificável, diante da existência de razão suficiente, o que sempre será analisado de acordo com os princípios constitucionais. 
Apenas que, sob o ângulo do direito ao reconhecimento do gênero de identificação como expressão da identidade, ao que parece, o tratamento desigual do transexual não se justifica e, muito pelo contrário, fomenta a discriminação, em ofensa ao princípio constitucional da igualdade.

\section{5) A luta por reconhecimento na teoria de Axel Honneth: os} planos do amor e da solidariedade

A importância do reconhecimento como forma de inclusão do transexual é anotado por Francesco D'Agostino. O autor, ao tratar da interface entre direito e sexualidade pondera que, embora não pareça viável uma regulamentação da sexualidade como direito privado ou direito subjetivo à modificação do sexo, pois o direito não tem como garantir impossíveis, pode-se propiciar, por meio do direito, o acolhimento da diversidade pela comunicação, pelo reconhecimento do ser no meio social. ${ }^{456}$

Uma forma de obter tal acolhimento seria a admissão da identidade sexual como alternativa para diminuir a violência e a estigmatização cotidianamente experimentadas pelo transexual, viabilizando que seja admitido como um parceiro de interação, sem constrangimentos, em condições de igualdade. E essa igualdade, como se verá, não se realiza sem o reconhecimento.

Assim, assumida a relevância do reconhecimento jurídico para a concretização da igualdade, de rigor o aprofundamento, em busca de mecanismos que permitam fundamentar o reconhecimento jurídico do transexual.

Para tanto, auxiliam as lições de Axel Honneth sobre o reconhecimento.

A partir da ideia de Hegel, segundo a qual a formação prática da identidade humana pressupõe o reconhecimento intersubjetivo, e da psicologia de Mead, Honneth propõe-se a delinear uma teoria social baseada no reconhecimento recíproco nos níveis do amor, do direito e da solidariedade ou estima social; buscando também desenvolver o padrão moral e a autorrelação individual que corresponda a cada uma dessas formas de reconhecimento. Sua teoria está baseada na identificação de uma força moral que impulsiona a luta pelo reconhecimento e na consequência desse reconhecimento para a sociedade e para a pessoa.

\footnotetext{
${ }^{456}$ D’AGOSTINO, Francesco. Sexualidade e direito, in Bioética segundo o enfoque da filosofia do direito. Título original: Bioetica nella prospettiva della filosofia del diritto, cit., p. 139/140.
} 
Com base na ideia de que o homem constrói seu padrão de autorreferência por meio da relação com seus pares, Honneth fixa no reconhecimento recíproco a primeira etapa para o desenvolvimento da intersubjetividade.

De acordo com o filósofo, a primeira forma de reconhecimento recíproco é aquela que se dá pela perspectiva do amor, incluindo as "relações emotivas fortes entre poucas pessoas, segundo o padrão de relações eróticas entre dois parceiros, de amizades e de relações pais/filho". ${ }^{457}$ Inicia sua investigação pela relação mãe-bebê, da forma como entendida por Winnicot, para afirmar que a primeira experiência de individuação e reconhecimento do outro experimentada pelo Ser é aquela que se segue ao nascimento, pela superação da fase de fusão. Enquanto nessa fase há uma simbiose entre a mãe e o bebê, a partir dos seis meses o bebê começa a testar a realidade da existência materna como algo separado e que não lhe pertence e, a partir daí, delineia-se o primeiro reconhecimento do outro. Uma boa experiência nessa primeira etapa de vida assegura a vivência afetiva sobre a possibilidade de amar o outro, apesar da diferenciação estabelecida pela individuação recíproca. ${ }^{458}$ Honneth introduz na reflexão o conceito de "capacidade de estar só". Segundo o autor, sempre amparado nas lições de Winnicott, a capacidade de estar só pressupõe uma confiança da criança na durabilidade da dedicação materna, a qual permite que tolere as ausências da mãe, acreditando que haverá um breve retorno. Para Honneth, então, o processo de amadurecimento da primeira infância, pelo qual mãe e bebê passam a se perceber como pessoas independentes, ilustra a estrutura comunicativa que faz do amor uma relação de reconhecimento recíproco. ${ }^{459}$ Nesse ponto, Honneth propõe uma leitura do conceito de amor de Hegel, de "ser-si-mesmo em um outro", não como um estado intersubjetivo, mas como uma tensão entre a possibilidade de estar só e a vontade de estar fundido ao outro, assim sintetizando: "a "referencialidade do eu" e a simbiose representam aí os contrapesos mutuamente exigidos que, tomados em conjunto, possibilitam um recíproco estar-consigo-mesmo no outro". 460

$\mathrm{Na}$ análise de Ricouer, debruçando-se sobre o modelo de reconhecimento calcado no amor proposto por Honneth, dessa primeira experiência de separação entre a mãe e o bebê, elabora-se um modelo de relacionamento social afetivo, baseado na aquisição da capacidade de estar só e na confiança de que o vínculo subsistirá,

\footnotetext{
${ }^{457}$ HONNETH, Axel. Luta por reconhecimento, cit., p. 159.

${ }^{458}$ Idem, p. 170.

${ }^{459}$ Idem, p. 174/175.

${ }^{460}$ Idem, p. 175.
} 
permanecendo o "laço invisível que se tece na intermitência da presença e da ausência"." ${ }^{61}$ Daí sintetizar o filósofo francês que o reconhecimento relativo à esfera do amor se baseia na libertação dos laços afetivos fusionais e na confiança na permanência da vinculação recíproca entre parceiros, ${ }^{462}$ do que resulta a ideia normativa de aprovação social, em um nível pré-jurídico, sendo que a negação do reconhecimento sob esse signo importa na humilhação: “A humilhação, experimentada com a retirada ou recusa dessa aprovação, atinge cada um no seu nível pré-jurídico de seu "estar-com" outrem. O indivíduo sente-se como que olhado de cima, até mesmo tido como um nada. Privado de aprovação, é como se ele não existisse". ${ }^{463}$

Além do amor e da relação jurídica, que será autonomamente tratada, Honneth identifica, com amparo em Hegel e Mead, uma terceira esfera de reconhecimento recíproco necessária entre os homens: a da estima social, que ele aponta como condição para que os sujeitos possam referir-se positivamente a suas propriedades e capacidades concretas.

$\mathrm{O}$ autor estabelece nítida distinção entre o reconhecimento jurídico e o respeito social. Segundo Honneth, o reconhecimento na esfera jurídica baseiase na universalização do conceito de pessoa humana, enquanto o reconhecimento pela forma da estima social está fundado na valorização das diferenças pessoais que caracterizam os indivíduos. ${ }^{464} \mathrm{Na}$ lição de Honneth, a possibilidade de valorizar diferentes personalidades está diretamente ligada à abertura e ampliação dos valores e objetivos éticos da sociedade, uma vez que o " "valor" social se mede pelo grau em que cada um parece estar em condições de contribuir à realização das predeterminações dos objetivos sociais". 465

Acrescenta o autor que a estima social, ao contrário da relação jurídica, é uma forma de reconhecimento individualizante porque baseada na valorização da particularidade de cada um: "uma pessoa só pode se sentir "valiosa" quando se sabe reconhecida em realizações que ela justamente não partilha de maneira indistinta com todos os demais". ${ }^{466}$ Por isso, quanto maior a abertura das concepções axiológicas na

\footnotetext{
${ }^{461}$ RICOEUR, Paul. Percurso do Reconhecimento. Tradução de Nicolás Nyimi Campanário. São Paulo: Edições Loyola, 2006, p. 204.

${ }^{462}$ Idem, p. 211.

${ }^{463}$ Idem, p. 206.

${ }^{464}$ HONNETH, Axel. Luta por reconhecimento, cit., p. 199.

${ }^{465}$ Idem, p. 200.

${ }^{466}$ Idem, p. 204.
} 
valorização de distintos modos de vida, maior a possibilidade de estima social dirigida a diversas formas de realização individual na esfera privada.

Vale dizer, uma sociedade que atribua valor positivo a um número maior de formas de comportamento, como andar descalço, por exemplo, terá a possibilidade de estimar uma diversidade maior de condutas, como, no mesmo exemplo, aquela do indivíduo que anda descalço. O contrário parece igualmente verdadeiro, na medida em que não haverá estima àquele que anda sem sapato, se a sociedade não valorizar essa conduta.

Pode-se extrair, assim, que o estabelecimento da tolerância e da liberdade como objetivos sociais contribui para tornar aquele que é diferente digno de reconhecimento, não só no plano jurídico, com base na universal dignidade da pessoa humana, mas também sob o aspecto da solidariedade, por uma sociedade que valorize a diferença e, por isso, reconheça por meio da estima social aqueles que concretizam a existência de tal diferença, pela sociedade valorizada.

A experiência da estima social afeta a autorrelação individual, que na sociedade moderna não está ligada à identidade coletiva do grupo ou estamento, mas à valorização da identidade do indivíduo. Honneth alude, então, a uma solidariedade pós-tradicional, entre sujeitos individualizados e autônomos, que partilham objetivos, mas não necessariamente modos de vida comuns, desse modo referindo-se às relações solidárias: "elas não despertam somente a tolerância para com a particularidade individual da outra pessoa, mas também o interesse afetivo por essa particularidade: só na medida em que eu cuido ativamente de que suas propriedades, estranhas a mim, possam se desdobrar, os objetivos que nos são comuns passam a ser realizáveis". ${ }^{467}$

Honneth identifica a autoestima como a consequencia produzida pela estima social para a autorrelação. Relaciona a estima social a uma forma individual de reconhecimento contraposta ao reconhecimento por meio da relação jurídica, geral, e identifica, na degradação e na ofensa, as formas de desrespeito dessa esfera de reconhecimento, que ameaça a personalidade em seus componentes de honra e dignidade. Isso porque a honra, a dignidade e o status dependem da estima social dirigida à forma de autorrealização eleita pela pessoa, ou seja, dependem da atribuição de valores positivos, pela comunidade, a determinados modos de vida, ou crenças, a fim de que os próprios sujeitos reconheçam em si o valor social de suas escolhas e capacidades. Daí porque, "A

${ }^{467}$ HONNETH, Axel. Luta por reconhecimento, cit., p. 211. 
degradação valorativa de determinados padrões de autorrealização tem para seus portadores a consequência de eles não poderem se referir à condução de sua vida a algo a que caberia um significado positivo no interior de uma coletividade", resultando na perda da autoestima pessoal. ${ }^{468}$

\section{6) A negativa de reconhecimento no plano jurídico: violação}

\section{da igualdade e ofensa à dignidade}

Nos limites deste trabalho, sem pretender diminuir a relevância do reconhecimento sob as formas do amor e da solidariedade, o interesse nas lições de Honneth refere-se mais diretamente às experiências de desrespeito típicas do plano do direito, bem como às consequências provenientes dessas violações para a autorreferência da pessoa como centro de imputação moral.

A proposta consiste, então, em investigar sobre a potencialidade do reconhecimento jurídico para a concretização da igualdade, como alternativa para combater a discriminação, o preconceito e a violência de que são vítimas os transexuais.

A importância do reconhecimento pelo direito para a convivência coletiva e vida em sociedade é ressaltada por Paul Ricouer.

$\mathrm{Na}$ leitura que Ricoeur aprofunda sobre Hegel e Honneth, o desejo de ser reconhecido, do ponto de vista hegeliano, pode ser identificado como o motivo moral originário, apto a fundar a experiência política, tal qual o medo da morte violenta e o cálculo racional que este opõe à vaidade, ambos presentes no estado de natureza hobbesiano. Nas palavras do autor: "acabamos de dar ao motivo originário, que doravante está frente a frente com o medo da morte violenta, a denominação que lhe convém, a de desejo de ser reconhecido". 469

Ricoeur acrescenta que, no plano jurídico, a "capacidade de estar só" por Honneth tratada sob o ângulo do amor, é substituída pelo predicado "livre", no sentido de racionalidade presente em toda pessoa, enquanto a confiança é substituída pelo respeito, com a respectiva pretensão ao universal para além dos laços afetivos. ${ }^{470}$

Cumpre ora trazer as lições do próprio Honneth.

Sob o ângulo do direito, o filósofo atribui uma relevância essencial ao reconhecimento recíproco para possibilitar ao sujeito uma autorreferência

\footnotetext{
${ }^{468}$ Idem, p. $217 / 218$.

${ }^{469}$ RICOEUR, Paul. Percurso do Reconhecimento, cit., p. 189.

${ }^{470}$ Idem, p. 211.
} 
como centro de imputação de direitos e obrigações, afirmando que nossa consciência como sujeitos de direito nasce da percepção de que devemos respeitar o outro. Com base nas leituras que aprofunda sobre Hegel e Mead, afirma: "só podemos chegar a uma compreensão de nós mesmos como portadores de direitos quando possuímos, inversamente, um saber sobre quais obrigações temos de observar em face do respectivo outro". 471

Honneth localiza em torno do princípio da igualdade uma tensão que resulta em uma das formas de luta por reconhecimento: aquela ocorrida no plano jurídico. Na dicção do filósofo, o princípio da igualdade no direito moderno ampliou-se em duas frentes: uma primeira, relativa ao conteúdo material da igualdade, admitindo-se maiores chances individuais de realização de liberdades socialmente garantidas a todos, em comparação com a sociedade estamental; e uma segunda frente, estendida ao aspecto social, pela qual a igualdade é transmitida sempre a um número maior de membros da sociedade, em consequencia da universalização da relação jurídica a um círculo crescente de grupos. Do conflito nascido da experiência de desrespeito, resulta a luta pelo reconhecimento na esfera jurídica, “em torno da ampliação tanto do conteúdo material como do alcance social do status de uma pessoa de direito". ${ }^{472}$

Como anota o filósofo alemão, as relações jurídicas modernas estão construídas de modo universal, baseadas no valor fundamental da pessoa e, por isso, podem se tornar palco de luta por reconhecimento, pelo confronto entre normas universalmente válidas e sua efetiva aplicação diante de circunstâncias concretas. ${ }^{473}$

Honneth identifica na imputabilidade moral a capacidade humana natural que leva os sujeitos a se respeitarem mutuamente e a se reconhecerem como pessoas de direito na comunidade. Entende por imputabilidade moral a capacidade humana de decidir racionalmente com autonomia individual sobre questões morais e afirma: "sem uma semelhante atribuição, não seria absolutamente imaginável como os sujeitos devem ter podido alguma vez acordar reciprocamente acerca de uma ordem jurídica. Nesse sentido, toda comunidade jurídica moderna, unicamente porque sua legitimidade se torna dependente da ideia de um acordo racional entre indivíduos em pé de

\footnotetext{
${ }^{471}$ HONNETH, Axel. Luta por reconhecimento, cit., p. 179.

${ }^{472}$ Idem, p. 193/194.

${ }^{473}$ Idem, p. $186 / 187$.
} 
igualdade, está fundada na assunção da imputabilidade moral de todos os seus membros". ${ }^{474}$

A partir das lições de Honneth e Ricoeur, destarte, possível reconhecer na imputabilidade moral (ou racionalidade) e no desejo de ser reconhecido (ou respeitado) características essenciais a todos os seres humanos.

Da afirmação de que a autonomia para tomar decisões racionais e o desejo de ser reconhecido são notas comuns a todos os seres humanos resulta, então, a possível conclusão de que o desrespeito à identificação de gênero e a negativa de reconhecimento jurídico desse gênero resultam em violação da igualdade. Do mesmo modo, consistindo a identidade de gênero aspecto humano lapidado pelo sujeito a partir da própria imputabilidade moral, com aspiração de reconhecimento, de rigor admitir a todos idêntico direito à identidade, sob pena de ferir a igualdade jurídica e motivar a luta moral por direitos de reconhecimento.

Além da importância do reconhecimento como forma de concretização da igualdade no plano abstrato da norma, Honneth também se propõe a investigar a consequência da privação de direitos para a pessoa, sob o ponto de vista do respeito por si própria, que nestas linhas será relacionado com a dignidade humana.

Assinala o filósofo que, se todos partilham da mesma característica da imputabilidade moral, a negativa de direitos a alguns acaba por comprometer a ideia de ser merecedor de respeito pelo sujeito a quem são negados direitos. O filósofo inicia o desenvolvimento da ideia pelo que denomina autorrelação, ou seja, a consequencia do reconhecimento jurídico sobre a relação da pessoa com ela mesma. Com amparo nas lições psicológicas de Mead, afirma que o reconhecimento jurídico leva a uma autorrelação positiva, possibilitando que a pessoa intensifique a capacidade de se referir a si mesma como uma pessoa moralmente imputável, a quem foram adjudicados direitos. Nesse sentido, Honneth estabelece uma relação entre a autonomia e o reconhecimento, uma vez que, a partir do respeito que se revela pelo reconhecimento de direitos, a pessoa adquire consciência de poder respeitar a si própria. Nas palavras do filósofo: “o sujeito adulto obtém a possibilidade de conceber sua ação como uma manifestação da própria autonomia, respeitada por todos os outros, mediante a experiência do reconhecimento jurídico". 475

\footnotetext{
${ }^{474}$ Idem, p. 188.

${ }^{475}$ HONNETH, Axel. Luta por reconhecimento, cit., p. 194.
} 
A seguir, vale-se Honneth dos estudos de Joel Feinberg sobre o valor moral da adjudicação de direitos para construir sua ideia de que o reconhecimento jurídico está relacionado à conquista do autorrespeito. Das ideias de Mead acrescidas da tese de Feinberg, Honneth conclui que a possibilidade de exercer pretensões calcadas em direitos previamente reconhecidos reforça no indivíduo sua consciência de si como pessoa moralmente imputável. E, dessa autoconsciência positiva decorrente da possibilidade de se referir a si próprio como membro da coletividade que partilha os mesmos direitos, nasce o autorrespeito. Dada a relevância do ponto, vale transcrever: "É o caráter público que os direitos possuem, porque autorizam seu portador a uma ação perceptível aos parceiros de interação, o que lhes confere a força de possibilitar a constituição do autorrespeito; pois, com a atividade facultativa de reclamar direitos, é dado ao indivíduo um meio de expressão simbólica, cuja efetividade social pode demonstrar-lhe reiteradamente que ele encontra reconhecimento universal como pessoa moralmente imputável". ${ }^{476}$

Honneth conclui, nessa esteira, que a privação de direitos fundamentais, resultante do reconhecimento denegado, implica a perda da possibilidade de autorrespeito individual, ${ }^{477}$ que atinge a pessoa em sua esfera moral, pela exclusão de determinados direitos em sociedade. Para o autor, a negativa de direitos atinge o indivíduo em sua autonomia e em sua expectativa de ser reconhecido como sujeito capaz de formular juízos morais, de tal modo que leva ao "sentimento de não possuir o status de um parceiro de interação com igual valor, moralmente em pé de igualdade". ${ }^{478} \mathrm{Em}$ consequência da experiência da privação de direitos, produz-se uma perda do autorrespeito, pela impossibilidade de se referir a si próprio como titular dos mesmos direitos dos outros, o que leva à sensação de desigualdade na interação com os próximos. ${ }^{479}$

Essa desqualificação do indivíduo por si mesmo, em consequência de não ser reconhecido como alguém merecedor dos mesmos direitos admitidos aos outros, que Honneth denomina de perda do autorrespeito, transcende os limites da igualdade e alcança a própria dignidade da pessoa. De fato, na medida em que direitos inerentes à condição humana, por isso denominados fundamentais, não são reconhecidos a alguém, a própria essência humana é atingida e negada, do que resulta a violação da dignidade.

\footnotetext{
${ }^{476}$ Idem, p. 197.

${ }^{477}$ Idem, p. 198.

${ }^{478}$ Idem, p. 216.

${ }^{479}$ Idem, p. 217.
} 
Nesses termos, pode-se concluir que o tratamento diferenciado ao transexual, pela negativa de reconhecimento de sua identidade, consiste em violação da igualdade, uma vez que é exatamente a capacidade de tomar decisões com autonomia e de ser reconhecido e respeitado por elas uma das notas comuns entre os homens, que, nessa medida, veda a distinção de tratamento.

Tal violação da igualdade implica consequências para a relação da pessoa consigo própria, comprometendo-lhe o autorrespeito, em razão da impossibilidade de que se perceba como alguém a quem foram adjudicados direitos partilhados pelos demais membros da comunidade, em ofensa à sua dignidade.

Por isso, o não reconhecimento, que se vislumbra na negativa do direito à identidade de gênero ao transexual, não obstante a absoluta igualdade entre os homens sob o ponto de vista da imputabilidade moral e do desejo de ser reconhecido, resulta em violação não apenas ao princípio da igualdade, mas também da dignidade inerente à condição humana, a qual independe da identidade de gênero.

\section{7) A discriminação e o preconceito}

Na metáfora de René Cassin, citado por Celso Lafer, o princípio da igualdade perante a lei e seu corolário, o princípio da não discriminação, são o pórtico do templo dos direitos humanos, sob o qual se erguem as colunas representativas dos direitos pessoais individuais, dos direitos pessoais de relacionamento, das liberdades públicas e direitos políticos, e dos direitos econômicos, sociais e culturais, ${ }^{480}$ revelando a essencialidade da não discriminação para a realização efetiva dos direitos humanos, sob o enfoque da igualdade.

Para Honneth, sempre que o ordenamento deixa de atuar como promotor e garantidor da igualdade, pela negativa do reconhecimento de direitos a alguns, uma força social impulsionada pela desigualdade é catalisada por meio da luta por reconhecimento, que, no plano jurídico, objetiva exatamente a expansão de direitos e a concretização da igualdade. Tal ideia pode ser assim decomposta: diante da incapacidade do Direito para garantir a igualdade em casos concretos, instaura-se uma luta, voltada ao reconhecimento de direitos e dos sujeitos de direito, resultando na expansão da igualdade no âmbito do próprio Direito.

\footnotetext{
${ }^{480}$ Declaração Universal dos Direitos Humanos, in História da Paz, Demétrio Magnoli (org), p. 316/317.
} 
Com base nas lições de Thomas H. Marshall, Honneth afirma que a "imposição de cada nova classe de direitos fundamentais foi sempre forçada historicamente com argumentos referidos de maneira implícita à exigência de ser membro com igual valor da coletividade política". ${ }^{481}$

Para o filósofo, se na modernidade o direito se afirma como universal, fundado na imputabilidade moral dos sujeitos de direito, eventual quebra da igualdade desperta uma luta pelo reconhecimento dos que se sentem desfavorecidos, valendo transcrever: "A institucionalização dos direitos civis de liberdade inaugurou como que um processo de inovação permanente, o qual iria gerar no mínimo duas classes de direitos subjetivos, porque se mostrou repetidas vezes na sequencia histórica, sob a pressão de grupos desfavorecidos, que ainda não havia sido dada a todos os implicados a condição necessária para a participação igual num acordo racional”. ${ }^{482}$

A negativa de direito fundamental a que se refere Honneth, desprovida de justa causa e violadora da igualdade, relaciona-se com a discriminação.

Na definição de Jorge Miranda, a discriminação corresponde a uma situação de desvantagem infundada, que deve ser proibida, de modo a proteger as pessoas. $^{483}$

Na lição de Bobbio, a discriminação é entendida como uma diferenciação injusta ou ilegítima, porque contrária ao princípio fundamental da justiça, segundo o qual devem ser tratados igualmente aqueles que são iguais. Ressalva o autor que não basta a constatação da diversidade, uma vez que os homens são naturalmente desiguais, ocorrendo a discriminação em fases ulteriores, primeiro pela introdução de um critério de distinção valorativo, que leve à superioridade de um e à inferioridade de outro, e, em segundo lugar, pelo acréscimo da concepção de que o superior tem o direito de escravizar, explorar e até eliminar o outro. ${ }^{484}$

À luz da igualdade ontológica entre os homens, que por si só não sustentaria qualquer crença da superioridade de uns em relação a outros, a discriminação encontra explicação na irracionalidade do preconceito, "entendido como uma opinião ou conjunto de opiniões que são acolhidas de modo acrítico passivo pela

\footnotetext{
${ }^{481}$ HONNETH, Axel. Luta por reconhecimento, cit., p. 191.

482 Idem, p. 192.

${ }^{483}$ Manual de Direito Constitucional. Tomo IV, cit., p. 253.

${ }^{484}$ BOBBIO, Norberto. A natureza do preconceito. In Elogio da serenidade e outros escritos morais. Tradução de Marco Aurélio Nogueira. São Paulo: editora Unesp, 2002, p. 107/109. 103/118.
} 
tradição, pelo costume, ou por uma autoridade cujos ditames são aceitos sem discussão", 485 ou como "maneiras de julgar que levam em conta considerações que nossas convenções excluem". 486

Assim conclui Bobbio que o mal-estar diante de uma minoria ou diante do irregular, do anormal ou do 'diferente' está fundado em preconceitos inveterados e em formas irracionais, puramente emotivas, de julgar os homens e os eventos. ${ }^{487}$

A moral convencional baseada na subjetividade do gosto incluise entre os fundamentos que explicam a crença de que algumas pessoas ou modos de vida são superiores e merecedores de maior respeito, em justificativa da negativa de direitos a outros. A distinção entre a moral convencional e a moral crítica é tratada por José Reinaldo Lima Lopes, ao analisar o debate travado entre Lord Devlin e Herbert Hart, por ocasião da proposta de descriminalização dos atos consensuais homossexuais entre adultos no Reino Unido. De um lado, identifica o professor a moral relacionada ao costume e à tradição, àquilo que o homem comum, a pessoa honesta aceita, tratando-se da moral defendida por Devlin; e de outro, a concepção de Hart, segundo a qual a moralidade deve incluir uma avaliação crítica, afastando-se da impressão e dos sentimentos e partindo da ideia de que a miséria, o sofrimento humano e a restrição à liberdade são objetivamente indesejáveis e devem ser combatidos, do que resulta a submissão da moralidade comum ao princípio de uma moral crítica. ${ }^{488}$

Tais lições revelam, assim, uma proximidade entre o preconceito e a moral convencional, ambos inspirados em formas emocionais e subjetivas de julgar ações e homens, as quais não parecem suficientes para justificar diferentes tratamentos em sociedades democráticas.

Na dicção de Bobbio, um dos efeitos da discriminação fundada na irracionalidade do preconceito e na moral tradicional é a exclusão de alguns do gozo de certos direitos, ${ }^{489}$ o que, na teoria de Honneth, desperta a luta por reconhecimento jurídico voltada à ampliação de direitos e de sujeitos de direito.

O direito atua, assim, ao mesmo tempo como garantidor da igualdade para a maioria e como negador da igualdade para a minoria, motivando a luta

\footnotetext{
${ }^{485}$ BOBBIO, Norberto. As razões da tolerância. In A era dos direitos, cit., p. 206/207.

${ }^{486}$ DWORKIN, Ronald. Liberdade e moralismo. in Levando os direitos a sério. Tradução de Nelson Boeira. São Paulo: Martins Fontes, 2002, p. 385/386.

${ }^{487}$ As razões da tolerância. In A era dos direitos cit., p. 207.

${ }^{488}$ LOPES, José Reinaldo Lima. O direito ao reconhecimento para gays e lésbicas. Flavia Piovesan e Daniela Ikawa (orgs). Direitos Humanos, Fundamento, Proteção e Implementação. Vol II, p. 947/948

${ }^{489}$ A natureza do preconceito. In Elogio da serenidade e outros escritos morais, cit., p. 116.
} 
moral voltada à ampliação da igualdade, por meio do reconhecimento dos mesmos direitos fundamentais a todos, no plano jurídico.

O papel ambivalente do direito no tratamento das diferenças não é novidade na doutrina. Para José Reinaldo Lima Lopes, o direito pode atuar como instrumento de atenuação das diferenças e de promoção da igualdade, afirmando: “A diferença é, pois, um construído histórico e o direito joga um papel não neutro nesta construção: pelo contrário, o direito - os ordenamentos postos - ajuda a naturalizar as diferenças e as desigualdades que são comuns na cultura. A mudança no direito não vem apenas em seguida das mudanças culturais, mas ajuda a promovê-las". ${ }^{490}$ Por outro lado, ressalta Joaquín Herrera Flores que o direito também pode servir de técnica de perpetuação da desigualdade e da discriminação: "Quando não se leva em conta a exclusão e a dominação, o jurídico atua não mais como um freio, mas como um catalisador da exploração e da subordinação, um instrumento que facilita a reprodução da referida exclusão e dominação, sob a aparência de neutralidade, universalismo e abstração" (tradução livre). ${ }^{491}$

Acrescenta Eduardo Appio, sobre as consequências pessoais que decorrem da discriminação por meio de lei que negue direitos a uma categoria de pessoas: “A restrição da liberdade (ou patrimônio) consiste em mero instrumento para o exercício da opressão, porque o que se pretende é expressar uma menos-valia em relação a essas pessoas, retirando-lhes a autoestima e o autorrespeito". 492

Anota Rodotà para a importância do reconhecimento da identidade sexual para a tutela da igualdade. Pondera que o estado civil é um instrumento de controle, divisão e discriminação entre as pessoas e que, por isso, deve ser analisado com prudência, especialmente no caso dos transexuais, a fim de evitar que um instrumento de certeza se torne um instrumento de discriminação. ${ }^{493}$

\footnotetext{
${ }^{490}$ LOPES, José Reinaldo de Lima. O direito ao reconhecimento para gays e lésbicas, cit., p. 952.

${ }^{491}$ Joaquín Herrera Flores. La construcción De Las Garantías. Hacia Una Concepción Antipatriarcal De La Libertad Y La Igualdad, cit., p. 125: “Cuando no se tiene en cuenta la exclusión y la dominación, lo jurídico actúa no ya como un freno, sino como un catalizador de la explotación y la subordinación, un instrumento que facilita la reproducción de dicha exclusión y dominación bajo la apariencia de neutralidad, universalismo y abstracción”.

${ }^{492}$ APPIO. Eduardo. Direito das minorias. Editora Revista dos Tribunais, 2009, p. 218.

${ }^{493}$ RODOTÀ, Stefano. Présentation Générale des problèmes liés au transsexualisme. In Transsexualisme, médicine e droit. Actes XXIII Colloque de droit européen. Vrije Universiteit Amsterdam (Pays-Bas) 1416 avril, 1993, p. 21. Disponível em: <books.google.com.br/books?id=5_ludHUsNAC\&printsec $=$ frontcovepage \&q=Transsexualisme $\% 2 C \% 20$ médicine $\% 20$ et $\% 20$ droit\&f=true $>, \quad$ p. $\quad 17-24$ último acesso em 16/12/2011.
} 
Nesses moldes, cumpre refletir sobre como concretizar, pelo direito, a igualdade de tratamento em relação às pessoas transexuais, evitando a perpetuação da marginalização. A partir daí, emerge a importância do reconhecimento jurídico como forma de efetivação da igualdade e proteção da dignidade, evitando privar alguns, por preconceito ou discriminação, de direitos fundamentais admitidos à maioria.

\section{8) O reconhecimento jurídico da identidade como forma de}

\section{inclusão}

Zigmunt Bauman, com base em Stuart Hall, constata uma explosão discursiva do tema da identidade, explorado na contemporaneidade por filósofos, cientistas sociais e psicólogos. Segundo o autor, a identidade tornou-se um prisma para o exame de outros tópicos da vida, como ocorre com a justiça e a igualdade, por exemplo, tendentes a serem conduzidas em termos de reconhecimento. ${ }^{494}$

Daí a importância de refletir sobre a identidade também sob o enfoque do reconhecimento, popularizado no movimento feminista, no movimento negro e na defesa das minorias, agregando à luta pela igualdade a busca pelo respeito às identidades coletivas, culturalmente discriminadas e desfavorecidas. ${ }^{495}$

Afirma Hurrell que, no plano internacional, a luta pelo reconhecimento, reputação e status, fundamental para os programas nacionalistas, não pode ser entendida fora do contexto internacional de disputas. ${ }^{496}$ Nos planos nacionais, Hurrell aponta também uma intensificação da luta por reconhecimento, por políticas de identidade, em consequência da ordem globalizada. Tais lutas incluem desde demandas por Estados próprios até mudanças políticas estruturais no âmbito dos Estados existentes, como no caso das minorias e refugiados, além das reivindicações de igualdade para as mulheres, nas constituições e leis internas de cada país. ${ }^{497}$

Politicamente, analisa Hurrel, tais movimentos e ideias pressionam por novas formas de políticas de identidade, não mais exclusivamente baseadas no território, mas harmonizadas com a cultura transnacional dos direitos humanos. ${ }^{498}$ Os direitos já admitidos pela ordem legal igualmente sofrem influência desses movimentos de

\footnotetext{
494 BAUMAN, Zigmunt. Identidade no mundo globalizante. In A sociedade individualizada: vidas contadas e histórias vividas. Tradução José Gradel. Rio de Janeiro: Jorge Zahar, 2008, p. 178.

${ }^{495}$ RICOEUR, Paul. Percurso do Reconhecimento, cit., p. 227.

${ }^{496}$ HURRELL, Andrew. Nationalism and the politics of identity. On global order. Power, Values, and the Constitution of International Society. Nova York: Oxford University Press, 2007, p. 124. (121-142).

${ }^{497}$ Idem, p. 141.

${ }^{498}$ Idem, mesma página.
} 
luta por reconhecimento, exigidos em maior amplitude e mais profundamente, sempre priorizando os direitos e clamores por identidade das pessoas. ${ }^{499}$

Nesse contexto, pode-se afirmar, com Bauman, que a busca por identidade não é uma característica do mundo pré-globalizado, que tenda a desaparecer, mas, ao contrário, corresponde ao "efeito colateral e o subproduto da combinação das pressões globalizantes e individualizadoras e das tensões que elas geram". 500

Visualiza-se, assim, uma crescente pressão para o reconhecimento de novas identidades nos planos internacional e nacional, inspirada pela força expansiva e pela eficácia irradiante dos direitos humanos, em direção à ampliação de direitos e de sujeitos de direito, de modo a cada vez mais diminuir o rol dos excluídos.

Autorizado estabelecer, assim, uma aproximação entre reconhecimento e identidade.

Nesse sentido, sustenta Michelangelo Bovero que tanto a identidade individual quanto a identidade coletiva são pretensões de reconhecimento do sujeito (pretese di riconoscimento da parte del singolo), afirmando que, ao responder à indagação “quem és?”, a pessoa expressa nada mais do que a forma pela qual pretende ser reconhecida entre seus pares. ${ }^{501}$

Denomina identidade individual aquela pretensão de reconhecimento pela qual o sujeito se distingue e se distancia dos outros; e coletiva, a pretensão de semelhança, pertencimento e vínculo com determinado grupo, ${ }^{502}$ tratando como sinônimos "identidade" e "pretensão de reconhecimento".

Acrescenta Bovero que a primeira acepção de identidade, individual ou pessoal, pressupõe sempre um contexto social em que o indivíduo possa referir-se a si mesmo como distinto dos demais. Daí vislumbrar uma dependência lógica da identidade pessoal em relação à coletividade, trazendo o significado latino da palavra persona, de máscara teatral, para fazer uma metáfora: a identidade como a representação do próprio papel, perante a coletividade. ${ }^{503}$

Adverte o autor italiano que a identidade do sujeito moderno pode se tornar um problema diante da variedade de chances, promessas e ofertas, que

\footnotetext{
${ }^{499}$ Idem, p. 141/142.

500 BAUMAN, Zigmunt. Identidade no mundo globalizante. In A sociedade individualizada: vidas contadas e histórias vividas, cit., p. 193.

${ }^{501}$ BOVERO, Michelangelo.Identità individuali e collettive. In Ricerche politiche due. Identità, interessi e scelte collettive, cit., p. 36 .

${ }_{502}$ Idem, mesma página.

${ }^{503}$ Idem, p. 41.
} 
acabam dificultando a construção da própria identidade de modo unívoco e coerente. À luz de tal risco, sugere a necessidade de que os sujeitos busquem uma política permissiva da liberdade individual, por meio de instituições e da garantia de condições para uma escolha de si aberta e universalmente consentida a todos. ${ }^{504}$ Para tanto, remete a uma dimensão essencial do contratualismo ou filosofia política que embasa a sociedade moderna: o pacto da ordem coletiva em que pretendemos viver, ditando as regras fundamentais para que nos seja assegurada a manutenção da própria identidade pessoal. ${ }^{505}$

A identidade como pretensão de reconhecimento inclui, assim, uma postulação jurídica, por direitos.

Lima Lopes fixa os pontos de partida dos direitos de reconhecimento, assim enumerados: 1) a existência de grupos estigmatizados na sociedade; 2) os estigmas como produtos institucionais e históricos e não realidades transcendentais ou cósmicas; 3) a possibilidade de que os estigmas não tenham fundamentos científicos, racionais ou funcionais para a sociedade; 4) a constatação de que as pessoas estigmatizadas são usurpadas de um bem imaterial básico que é o respeito e o autorrespeito; 5) a injustiça decorrente da manutenção social dos estigmas, provocando desnecessária dor, violência e desrespeito; e 6) o direito dos membros aviltados, para que continuem a ser membros da sociedade, de que lhes sejam retirados os estigmas aviltantes. ${ }^{506}$

A partir daí, assevera o autor: "o reconhecimento consiste na afirmação e na valorização positiva de certas identidades", 507 em busca de proteger um grupo estigmatizado das consequências jurídicas do estigma social.

No caso da transexualidade, identificam-se pretensões que, partindo de direitos a todos reconhecidos, como a personalidade e o estado civil, voltam-se ao reconhecimento da identidade de gênero ou sexual, no aprofundamento dos direitos existentes, paradigmaticamente ilustrando, no plano interno, o ponto sobre o qual se debruçou Hurrell, em sua análise da ordem global.

Os reclamos objetivam assegurar ao transexual uma melhor condição como sujeito de direitos, poupando-o dos constrangimentos inerentes ao nome e sexo biológico contraditórios com a sensação de pertencimento e a aparência da pessoa.

\footnotetext{
${ }^{504}$ Idem, p. 55/56.

${ }^{505}$ BOVERO, Michelangelo.Identità individuali e collettive. In Ricerche politiche due. Identità, interessi e scelte collettive, cit., p. 56.

${ }^{506}$ LOPES, José Reinaldo de Lima. O direito ao reconhecimento para gays e lésbicas. Direitos humanos: fundamentos, proteção e implementação, cit., p. 951.

${ }^{507}$ Idem, p.959.
} 
As pretensões de reconhecimento referem-se, assim, a aspectos da personalidade humana relacionados ao corpo, ao nome e ao estado civil, que serão em seguida examinados. 


\section{IV) OS DIREITOS DA PERSONALIDADE E A}

TRANSEXUALIDADE

\section{Introdução}

A concepção de direitos da personalidade parte do reconhecimento de direitos valiosos e extrapatrimoniais, merecedores de amparo e proteção da ordem jurídica. As características de universais e absolutos indicam a aproximação dos direitos da personalidade com os direitos humanos, reconhecendo-se em ambos uma gênese jusnaturalista. ${ }^{508}$

Baseado em tal premissa, sustenta José Roberto Franco da Fonseca a possibilidade de designar os direitos humanos como "direitos fundamentais da pessoa ou direitos essenciais à personalidade, para distingui-los dos direitos adquiridos". 509

No ordenamento interno, representam a introjeção do valor da dignidade humana que orienta o sistema internacional de proteção dos direitos humanos, ${ }^{510}$ concebidos à luz da "intangibilidade ética do patrimônio físico e moral do ser humano, de seus valores extrínsecos e intrínsecos, em todas as dimensões do viver físico, moral, mental e espiritual". 511

Daí a concepção da personalidade da pessoa singular como uma qualidade jurídica que emana diretamente da dignidade do homem, tratando-se de condição indispensável para a realização de seus fins ou interesses, reconhecida a todos os seres humanos. 512

Assumida a dignidade universal com base na igualdade essencial dos seres humanos, cabe aos direitos da personalidade a proteção da diferença, ${ }^{513}$ do que decorre a importância de seu estudo, entre os fundamentos concorrentes para oferecer a tutela jurídica aos transexuais.

\footnotetext{
${ }^{508}$ MELLO, Cláudio Ari. Contribuição para uma teoria híbrida dos direitos da personalidade. In O novo código civil e a constituição. Ingo Wolfgang Sarlet (org). $2^{\text {a }}$ ed. Porto Alegre: Livraria do Advogado, 2006, p. 92.

${ }^{509}$ Dimensão internacional dos direitos fundamentais da pessoa. Revista da Faculdade de Direito da USP, $\mathrm{n}^{\mathrm{o}}$ 88, 1993, p. 489 (487-496).

${ }^{510}$ PIOVESAN, Flavia. RUSSO JUNIOR. Rômolo. Direitos Humanos, Dignidade Humana e Direitos da Personalidade. In $\mathbf{O}$ Código Civil e sua interdisciplinariedade. Os reflexos do Código Civil nos demais ramos do direito. (coord) José Geraldo Brito Filomeno e outros. Belo Horizonte: Del Rey, 2004, p. 3.

${ }^{511}$ Idem, p. 16.

${ }^{512}$ MOTA PINTO, Carlos Alberto da. Teoria Geral do Direito Civil. Coimbra: Coimbra Editora, 1999, p. 86.

${ }^{513}$ MELLO, Claudio Ari. Contribuição para uma teoria híbrida dos direitos da personalidade. In O novo código civil e a constituição, cit., p. 93.
} 


\section{1) Os direitos da personalidade}

Os direitos da personalidade consistem em proteção do ser humano contra ingerências de terceiros, na salvaguarda de seu eu e funções. ${ }^{514}$ Correspondem a direitos essenciais da pessoa, voltados à tutela de sua dignidade. ${ }^{515}$ Daí se afirmar que ilustram a inter-relação estabelecida entre a Constituição Federal e o Código Civil, em consequência dos reflexos do princípio da dignidade da pessoa humana e da tutela constitucional dos direitos da personalidade. ${ }^{516}$

Diante da omissão legislativa quanto à previsão de um direito geral da personalidade no Brasil, como existente no art. 70, do Código Civil Português, localiza-se no princípio constitucional da dignidade humana seu fundamento. ${ }^{517}$

Segundo Caio Mário da Silva Pereira, os direitos da personalidade respondem a um ideal de justiça e ocupam posição supraestatal e, por serem diretamente derivados da natureza humana, não podem ser subtraídos pelo legislador. ${ }^{518}$ Após discorrer sobre as teorias da escola do direito natural e da escola positivista, conclui Caio Mário que os direitos da personalidade são protegidos em todas as legislações, "seja como expressão do pensamento jusnaturalista, seja abstraindo-se dele". ${ }^{519}$ Identifica, entre os direitos da personalidade positivados na Constituição brasileira, direitos adquiridos e direitos inatos: os primeiros decorrentes do status individual, existentes nos termos e na extensão disciplinada pelo direito, e os segundos, anteriores e superiores à lei, como a vida e a integridade física e moral. ${ }^{520}$

Francisco Amaral, após atribuir a Gierke a paternidade da denominação direitos da personalidade, localiza, já nos primórdios da civilização ocidental, marcos significativos, exemplificando, com base no Código de Hamurabi, a existência de sanções à lesão à integridade física ou moral do corpo humano (§§ 195-197 e 202). ${ }^{521}$ Aponta o civilista fluminense que a filosofia grega contribuiu para a teoria dos direitos da personalidade, ao admitir o dualismo das fontes jurídicas: um direito natural, como ordem superior criada pela natureza, expressão ideal de valores morais superiores da

${ }^{514}$ CAMPOS, Diogo Leite de. Lições de Direitos da Personalidade. $2^{\mathrm{a}}$ ed. Coimbra: Coimbra Editora, 1995 , p. 49.

${ }^{515}$ GOMES, Orlando. Introdução ao Direito Civil. $19^{\mathrm{a}}$ ed. Rio de Janeiro: Forense, 2008, p. 134.

516 ANDRADE, Fábio Siebeneichler de. Considerações sobre a tutela dos direitos da personalidade no Código Civil de 2002. In O novo código civil e a constituiçãa. Ingo Wolfgang Sarlet (org). $2^{\mathrm{a}}$ ed. Porto Alegre: Livraria do Advogado, 2006, p. 103.

517 Idem, p. 105.

${ }^{518}$ PEREIRA, Caio Mario da Silva. Instituições de Direito Civil, cit., p. 237.

${ }^{519}$ Idem, p. 239.

520 Idem, p. 242.

${ }^{521}$ AMARAL, Francisco, Direito Civil: Introdução, cit., p. 288/289. 
ordem vigente; e um direito positivo, consubstanciado nas leis estabelecidas na cidade, pelo que afirma: "No direito natural encontra-se, portanto, o germe dos direitos naturais ou inatos, direitos inerentes ao homem e preexistentes ao Estado, que os devia conhecer e respeitar". 522

Os direitos da personalidade afirmaram-se primeiramente na Alemanha, contra a resistência de Savigny, que considerava falso o direito do homem sobre sua pessoa, o que levaria em última instância à legitimação do suicídio. ${ }^{523}$ Acabou prevalecendo a tese desenvolvida por Gierke, quanto ao reconhecimento e necessidade de proteção dos direitos da personalidade. ${ }^{524}$

Após discorrer sobre a dificuldade de conceituar os direitos da personalidade, afirma Orlando Gomes que noção clara pode ser obtida a partir da delimitação de seu objeto, fixado nos bens jurídicos em que se convertem projeções físicas ou psíquicas individualizadoras da pessoa humana. ${ }^{525}$

Críticas à formulação dos direitos da personalidade em função da aparente confusão entre o sujeito e o objeto resolvem-se, assim, com base na definição alargada do conceito de bem jurídico. Ensina o mestre Orlando Gomes que, em direito, toda utilidade, material ou não, sobre a qual incide a faculdade de agir do sujeito, constitui um bem e pode figurar como objeto de relação jurídica, na medida em que sua noção é histórica e não naturalística. A partir daí, nada impede que certas qualidades, atributos, expressões ou projeções da personalidade sejam tuteladas no ordenamento jurídico como objetos de direito de natureza especial. ${ }^{526}$ Ou seja, a personalidade, atributo jurídico dirigido a regular as condições da atividade da pessoa como sujeito de direitos, ${ }^{527}$ define-se por particularidades que em conjunto identificam a pessoa, como o nome, o estado e o domicílio, ${ }^{528}$ sobre as quais versam os direitos da personalidade.

Mota Pinto alude também à vida, à saúde, à integridade física, à honra, à liberdade física e psicológica, à imagem e à reserva da intimidade da vida privada, vislumbrando aí "um círculo de direitos necessários; um conteúdo mínimo e imprescindível da esfera jurídica de cada pessoa". 529

\footnotetext{
${ }^{522}$ Idem, p. 289.

${ }^{523}$ GOMES, Orlando. Introdução ao Direito Civil. 19a ed. Rio de Janeiro: Forense, 2008, p. 134.

${ }^{524}$ Idem, p. 135.

${ }^{525}$ Idem, p. 136.

${ }^{526}$ Idem, mesma página.

${ }^{527}$ Idem, p. 127.

${ }^{528}$ Idem, p. 133.

${ }^{529}$ MOTA PINTO, Carlos Alberto da. Teoria Geral do Direito Civil, cit., p. 87.
} 
Na lição de Francisco Amaral, o “objeto dos direitos da personalidade é o bem jurídico da personalidade, como conjunto unitário, dinâmico e evolutivo dos bens e valores essenciais da pessoa no seu aspecto físico, moral e intelectual", 530 a partir do que se pode afirmar que a tutela da personalidade abrange, além dos elementos individualizantes, a proteção da integridade física, psíquica e moral.

A integridade psíquica, como afirma Giselle Câmara Groeninga, pode ser entendida como um dos mais fundamentais direitos da personalidade, considerando que o psiquismo nos dá a qualidade humana, por meio do direito a ter uma personalidade humana - implicando o "Direito a Ser Humano". 531

Assim, pode-se afirmar que a tutela da pessoa abrange também a proteção do elemento psicológico, sob a denominação de integridade psíquica, no pressuposto de que tal dimensão imaterial igualmente compõe a personalidade. A importância do elemento psicológico na salvaguarda da integridade humana foi reconhecida pela Organização Mundial de Saúde - OMS, ao definir saúde como um estado completo de bem-estar físico, mental e social, superando a ideia de ausência de doença ou enfermidade.

De todo modo, em que pese a inexistência de um direito geral da personalidade no ordenamento brasileiro, reconhece a doutrina que, sob a proteção da inviolabilidade da personalidade física e moral, o Código Civil assegura os direitos à identidade, ao nome, à imagem, à honra, à respeitabilidade e à vida privada" ${ }^{532}$ Por isso, como anota Teresa Ancona Lopez, atualmente se mostra irrelevante a distinção doutrinária entre os direitos da personalidade, visto que todos são direitos fundamentais da pessoa, que têm de ser respeitados pelo Poder Público e particulares. ${ }^{533}$

Nestas linhas, à luz do tema em desenvolvimento, optou-se pelo estudo do direito ao corpo, ao nome e ao estado, especificamente no que toca ao sexo que identifica a pessoa em seu registro civil.

Antes de prosseguir com o tratamento desses elementos individualizantes da pessoa, contudo, cabe adiantar que a perspectiva do exame está fundada na premissa de que os direitos da personalidade, como todos os demais direitos,

\footnotetext{
${ }^{530}$ AMARAL, Francisco, Direito Civil: Introdução, cit., p. 286.

531 GROENINGA, Giselle Câmara. $O$ direito à integridade psíquica e o livre desenvolvimento da personalidade, in "Família e Dignidade Humana" - Anais do V Congresso Brasileiro de Direito de Família, p. 440.

532 PIOVESAN, Flavia. RUSSO JUNIOR. Rômolo. Direitos Humanos, Dignidade Humana e Direitos da Personalidade. In $\mathbf{O}$ Código Civil e sua interdisciplinariedade. Os reflexos do Código Civil nos demais ramos do direito, cit., p. 14.

${ }_{533} \mathbf{O}$ dano estético. Responsabilidade civil. $3^{\text {a }}$ ed. São Paulo: RT, 2004, p. 56.
} 
não são absolutos, assumido o princípio da dignidade humana como limite superior e vetor de interpretação de todo direito. Por outro lado, entendendo a personalidade como forma de expressão jurídica da pessoa, claro está que as restrições ao seu desenvolvimento não podem implicar a supressão da autonomia, ensejando uma profunda reflexão, bem sintetizada nas indagações de Maria Celina Bodin de Moraes: “"quando' (em que circunstâncias?) e 'quanto' (em que medida?), à luz do princípio maior da dignidade humana, podemos dispor, com autonomia e informação, acerca de nós mesmos? Que limites deverão ser impostos à autodeterminação?". 534

A partir daí, os direitos ao corpo, ao nome e ao estado serão estudados sob o ângulo dos limites estabelecidos pela ordem jurídica no que toca às mudanças físicas, do nome e do sexo, sempre com vistas a tornar efetivo o princípio da dignidade humana em relação à pessoa transexual.

\section{2) O corpo humano: uma unidade material e imaterial}

A fixação dos contornos do direito sobre o próprio corpo não é simples, tratando-se de tema em que o Direito sofre forte influência da moral e da religião, exemplificada pela ideia de sacralidade do corpo.

Por séculos, o corpo foi encarado como uma dádiva divina a ser protegida dos desígnios individuais, verificando-se, na modernidade, a inserção da integridade corporal no âmbito da autonomia da vontade, o que levou à identificação do “direito ao próprio corpo", 535 cujos limites devem ser fixados.

Guy Durand identifica, na cultura ocidental, duas concepções de corpo humano: a dualista e a unitária, situando nas culturas greco-romana e judaico-cristã seus respectivos fundamentos. De acordo com o autor, na cultura greco-romana, inspirada na tradição Platônica, o corpo é algo separado da pessoa e visto como objeto revelado pela fórmula "eu tenho um corpo", própria da visão dualista do ser humano. Já na cultura judaica, o corpo designa um ponto de vista sobre a pessoa, sintetizada na fórmula "eu sou um corpo", tratando-se de visão subjetiva ou simbólica do corpo e própria de uma visão unitária de pessoa. ${ }^{536}$

\footnotetext{
${ }^{534}$ MORAES, Maria Celina Bodin de. Na medida da pessoa humana: estudos de direito civil, cit., p. 134.

${ }_{535}^{53}$ SCHREIBER, Anderson. Direitos da Personalidade. São Paulo: Atlas, 2011, p. 32.

${ }^{536}$ DURAND, Guy. Introdução Geral à bioética. História, conceitos, instrumentos. Tradução de Nicolás Nyimi Campanário. Original: Introduction générale à la bioéthique. Saint-Laurent Quebec, Canadá: Éditions Fides. São Paulo: Centro Universitário São Camilo; Loyola, 2a Ed., 2007, p. 291.
} 
O pensamento cartesiano, que reproduz o modelo platônico, contribuiu para a construção da ideia de corpo aproximada de uma máquina, separado do espírito: o corpo como um conjunto de peças, não pensante, contraposto ao espírito, reflexivo e autônomo, sintetizado na máxima "Penso, logo existo". 537 Essa visão dualista implicou uma objetivação do corpo resultante da ruptura concreta entre o ser humano e seu corpo, abrindo caminhos para a investigação científica e inspirando os primeiros anatomistas. $^{538}$

Para a cultura hebraica, diversamente, o corpo humano é uma totalidade dinâmica e indivisa. A palavra corpo não existe, utilizando-se carne, em substituição. Nesse sentido, a expressão "toda carne" significava para os hebreus todos os seres humanos. ${ }^{539}$

Identifica Guy Durand outras várias influências incorporadas na ideia de corpo própria da cultura ocidental: de Freud, a importância atribuída ao inconsciente e ao corpo; da interpretação bíblica, a valorização do pensamento hebraico; além da influência de filósofos, especialmente da corrente fenomenológica. Nesse aspecto, releva anotar a distinção formulada por Merleau-Ponty entre corpo-objeto ou corpomedido e corpo-vivido ou corpo próprio, segundo a qual, enquanto o primeiro é aquele que pode ser objeto de investigação científica, o segundo é o corpo colocado em ação pelo sujeito em seus comportamentos significativos, tratando-se de unidade implícita e confusa. ${ }^{540}$

A reflexão filosófica sobre a relação existente entre corpo e mente, se una ou dual, pode ser sintetizada na indagação de Thomas Nagel: "a mente é diferente do cérebro, embora esteja vinculada a ele, ou ela é o cérebro? Seus pensamentos, sentimentos, percepções, sensações e desejos são coisas que acontecem além de todos os processos físicos que ocorrem no seu cérebro, ou são, elas próprias, alguns desses processos físicos?". 541

Sem a preocupação de dar um fim definitivo ao debate, o professor americano identifica duas alternativas de resposta: a primeira baseada na crença de que o ser humano é constituído de um organismo físico e de uma alma mental, em

\footnotetext{
${ }^{537}$ MALHERBE, Jean-François. Pour une éthique de la medicine, Paris, Larousse, 1987, apud Durand, Guy. Introdução Geral à bioética. História, conceitos, instrumentos. Tradução de Nicolás Nyimi Campanário. Original: Introduction générale à la bioéthique. Saint-Laurent Quebec, Canadá: Éditions Fides. São Paulo: Centro Universitário São Camilo; Loyola, 2a Ed, 2007, p. 291.

${ }^{538}$ DURAND, Guy. Introdução Geral à bioética. História, conceitos, instrumentos, cit., p. 291/292.

${ }^{539}$ Idem, p. 293.

540 Idem, mesma página.

${ }^{541}$ Uma Breve Introdução à filosofia. Tradução de Silvana Vieira. São Paulo: Martins Fontes, 2001, p. 28.
} 
interação; e uma segunda, calcada na premissa de que as pessoas não passam de matéria física e que seus estados de espírito são estados físicos cerebrais, denominada fisicalista ou materialismo, ${ }^{542}$ segundo a qual: "a única coisa que existe é o mundo físico, que pode ser estudado pela ciência: o mundo da realidade objetiva". ${ }^{543}$

A complexidade da questão faz-se presente na indagação de Giovanni Berlinguer e Volnei Garrafa, citados por Guilherme Calmon Nogueira da Gama: "nós somos ou possuímos o nosso corpo? Acrescentando, assim, um novo elemento de reflexão ao antigo dilema entre o ser e o ter". ${ }^{544}$

\section{2.a) O direito ao corpo no ordenamento brasileiro}

A par do debate filosófico, no campo do Direito a doutrina afirma a existência de um direito ao próprio corpo, classificado por Orlando Gomes como subitem do direito à integridade física. ${ }^{545}$ Tal direito configura-se pela possibilidade de disposição de partes do corpo, em vida ou após a morte, por finalidade científica ou humanitária, subordinada à preservação da vida e de sua deformidade. ${ }^{546}$ Confere ao seu titular o poder de evitar ou fazer cessar qualquer ato atentatório contra seu corpo ou sua saúde. $^{547}$

O direito à integridade psíquica é tratado autonomamente por Pontes de Miranda, para quem se trata de um direito absoluto de integridade, ao lado da integridade física, inato e anterior ao nascimento, que proíbe a mãe de ingerir substâncias prejudiciais ao nascituro, em proteção ao seu desenvolvimento psíquico. Na lição do mestre, ao direito de integridade psíquica "corresponde o dever de todos de não causar danos à psique de outrem, e do Estado, ou dos parentes, de velar pelos insanos da mente". 548

No Código Civil brasileiro, o direito ao corpo é objeto do art. 13: “ Salvo por exigência médica, é defeso o ato de disposição do próprio corpo, quando importar diminuição permanente da integridade física, ou contrariar os bons costumes".

\footnotetext{
542 NAGEL, Thomas. Uma Breve Introdução à filosofia, cit., p. 30/31.

${ }^{543}$ Idem, p. 35.

${ }^{544}$ A nova filiação. O biodireito e as relações parentais: o estabelecimento da parentalidade-filiação e os efeitos jurídicos da reprodução assistida heteróloga, cit., p. 125.

545 Idem, p. 138.

${ }^{546}$ PEREIRA, Caio Mario da Silva. Instituições de Direito Civil, cit., p. 250.

${ }^{547}$ SZANIAWSKI, Elimar. Direitos da personalidade e sua tutela. São Paulo: RT, 1993, p. 273.

${ }^{548}$ Tratado de Direito Privado. Vol. VII. $2^{\mathrm{a}}$ ed. Rio de Janeiro: Editor Borsoi, 1956, p. 28.
} 
O legislador, na lição da doutrina, acolheu "a concepção unitária, que afasta a dissociação entre o corpo e a própria pessoa", ${ }^{549}$ própria da tradição judaico-cristã e aproximada da concepção tomista, pela qual a alma consistia em forma substancial do corpo, em fusão, inexistindo separação entre o espírito e a identidade sexual corporificada. ${ }^{550}$

Pietro Pierglingieri, no comentário ao art. $5^{\circ}$ do Código Civil Italiano, de redação bastante semelhante ao art. 13, do Código brasileiro, ${ }^{551}$ entende que, concebida a proteção da pessoa humana como uma proteção integral e adotada a concepção de pessoa como estrutura unitária, composta de elementos materiais e imateriais, de rigor interpretar a proteção à integridade física como uma proteção estendida também à integridade psíquica. ${ }^{552}$

A partir daí, introduz o conceito de integridade psicofísica, que afirma essencial para a saúde, admitida ao mesmo tempo como um direito e um dever da pessoa consigo própria. ${ }^{553}$

Da unidade da pessoa humana resultaria a impossibilidade de separar sua parte física de sua parte psíquica, impossibilitando distinguir o corpo, do sujeito titular, concluindo Perlingieri que a integridade psicofísica não é algo externo ou um objeto componente da pessoa e de sua personalidade, mas um pressuposto para que ela possa se desenvolver e realizar plenamente. ${ }^{554}$

Para Perlingieri, um dos limites ao exercício dos direitos da personalidade é a saúde da pessoa, tutelada constitucionalmente não apenas no interesse do sujeito, mas também por razões sociais. ${ }^{555}$ Por isso, a lei não considera a disponibilidade sobre o próprio corpo como uma questão que se exaure na esfera individual do sujeito, estabelecendo-lhe limites de ordem pública.

Na dicção de Capelo de Souza, o conteúdo do bem jurídico protegido sob o direito ao corpo igualmente inclui, além do conjunto físico-anatômico, o

\footnotetext{
${ }^{549}$ TEPEDINO, Gustavo; BARBOZA, Heloísa Helena; e MORAES, Maria Celina Bodin de. In Código Civil Interpretado conforme a Constituição da República. Rio de Janeiro: Renovar, 2004, comentários ao art. 13, p. 35 .

${ }^{550}$ D'AGOSTINO, Francesco. "Sexualidade e direito" in Bioética segundo o enfoque da filosofia do direito, cit., p. 131.

551 "Gli atti di disposizione del proprio corpo sono vietati quando cagionino una diminuzione permanente della integrità fisica, o quando siano altrimenti contrari alla légge, all'ordine pubblico o al buon costume".

${ }^{552}$ La personalità umana nell'ordinamento giuridico. Camerino: Scuola di perfezionamento in diritto civile dell'Università di Camerino, 1972, p. 310.

${ }^{553}$ Idem, p. 312/313.

${ }^{554}$ Idem, p. 314.

${ }^{555}$ La personalità umana nell'ordinamento giuridico. Camerino: Scuola di perfezionamento in diritto civile dell'Università di Camerino, 1972, p. 312.
} 
equipamento psíquico do homem como integrante do conjunto corporal, a partir do que o autor se refere à saúde físico-psíquica. ${ }^{556}$ Identifica no corpo uma natureza bipolar: um lado regido por uma dinâmica inata, própria da materialidade animal, e outro lado reflexivo, que perspectiva, pondera e escolhe finalidades de ação, conduzindo o comportamento corporal na direção desejada. Dessa dicotomia resulta, na lição do autor, a ramificação do direito ao corpo em dois grandes troncos: um inerente à integridade ou incolumidade corporal, e outro que reconhece um poder de autodeterminação sobre o próprio corpo. ${ }^{557}$

Ou seja, sob a denominação de "direito ao corpo", o ordenamento tutela a integridade humana física e psíquica, rejeitando a ideia de corpo como objeto ou estrutura inanimada e aproximando as noções de corpo e sujeito, pela adoção da concepção de pessoa como uma unidade essencial, cuja dignidade é tutelada.

Daí se reconhecer, também no direito brasileiro, a existência de uma proteção integral ao indivíduo, inclusiva de seus elementos físicos e psíquicos, a partir do entendimento de que se trata de aspectos inseparáveis da pessoa humana, tutelada pelos direitos da personalidade, admitindo-se o direito à integridade psicofísica. ${ }^{558}$

Nesse sentido, o teor do Enunciado $n^{\circ}$ 6, da Primeira Jornada de Direito Civil promovida pelo Centro de Estudos da Justiça Federal: "A expressão "exigência médica" contida no artigo 13 refere-se tanto ao bem-estar físico quanto ao bemestar psíquico do dispoente”.

2.b) A cirurgia para a mudança de sexo, à luz do art. 13, do

\section{Código Civil Brasileiro}

A integridade física inclui-se entre os direitos essenciais e inatos, ${ }^{559}$ sobrepostos a qualquer condição legislativa, caracterizados como absolutos, irrenunciáveis, intransmissíveis e imprescritíveis. ${ }^{560}$

Tais características, contudo, não se confundem com a ausência de limites ao exercício do direito ao corpo. Como ensina Caio Mario da Silva Pereira, a ordem jurídica às vezes estabelece exceções aos atributos dos direitos inatos, "no interesse

\footnotetext{
${ }^{556}$ CAPELO DE SOUZA, Rabindranath. O direito geral de personalidade, cit., p. 213/214.

${ }^{557}$ Idem, p. 218.

${ }^{558}$ SZANIAWSKI, Elimar. Limites e possibilidades do direito de redesignação do estado sexual, cit., p. 80.

${ }^{559}$ DE CUPIS, Adriano. O direito à integridade física. In Os direitos da personalidade, cit., p. 69.

${ }^{560}$ PEREIRA, Caio Mario da Silva. Instituições de Direito Civil, cit., p. 242.
} 
do próprio indivíduo ou da coletividade". ${ }^{561}$ Nessa esteira, afirma Capelo de Souza que o poder de autodeterminação sobre o corpo perde sua licitude quando atenta contra a vida ou contra o próprio corpo, quando contraria uma disposição legal, os bons costumes ou os princípios de ordem pública. ${ }^{562}$

Pode-se afirmar, nesses moldes, que o exercício do direito ao corpo deve observar os limites impostos pelo ordenamento e especialmente não afrontar o princípio da dignidade da pessoa humana, do que resulta o direito de disposição de partes do corpo humano, mas não de forma absoluta. ${ }^{563}$

Heloisa Helena Barboza reconhece "um direito ao corpo, não patrimonial, mas pessoal, de caráter especial, inscrito dentre os direitos personalíssimos, tendo por conteúdo a livre disposição do corpo, dentro dos limites assinalados pelo direito positivo". ${ }^{564}$ A faculdade de dispor do próprio corpo, destarte, é limitada pela ordem pública representada, entre outros, pelo princípio da dignidade humana, atuando como verdadeiro impedimento à reificação do corpo. Por isso, sustenta Heloisa Helena Barboza a inexistência de um direito real da pessoa sobre as partes de seu corpo, entendendo necessário que, para o exercício do direito ao corpo, exista expressa autorização na ordem jurídica. ${ }^{565}$

Em relação à licitude da mudança de sexo, obtempera Perlingieri que a cirurgia não resulta do mero desejo, mas de uma concepção do direito à integridade como um direito-dever, cabendo à pessoa zelar por seu equilíbrio psicofísico, atenta à expectativa social. Afirma o professor italiano que da intersecção dos direitos à saúde e à integridade psicofísica com os direitos da personalidade resulta uma ideia de defesa da saúde voltada ao desenvolvimento da pessoa, em reforço a sua concepção do direito à saúde como direito-dever, no sentido de que cada um possui ao mesmo tempo o direito e o dever de se desenvolver plenamente, respeitando e conservando a própria identidade física, em direção ao desenvolvimento de sua personalidade. ${ }^{566}$ Nesse sentido, a disposição do corpo inerente à transexualidade responderia à exigência do dever consigo próprio, por isso coadunada com a tutela da dignidade humana.

\footnotetext{
${ }^{561}$ Idem, mesma página.

${ }^{562}$ CAPELO DE SOUZA, Rabindranath. O direito geral de personalidade, cit., 1995, p. 226.

563 GAMA, Guilherme Calmon Nogueira da. A nova filiação. O biodireito e as relações parentais: o estabelecimento da parentalidade-filiação e os efeitos jurídicos da reprodução assistida heteróloga, cit., p. 123.

${ }^{564}$ BARBOZA, Heloisa Helena. Direito ao corpo e doação de gametas. In Rios, André Rangel (org) Bioética no Brasil. Espaço e Tempo, p. 44.

${ }^{565}$ Idem, p. 46.

${ }^{566}$ La personalità umana nell'ordinamento giuridico, cit., p. 313.
} 
No direito brasileiro, a regulação do direito ao corpo encontra-se no art. $13,{ }^{567}$ do Código Civil, que, ao tutelar seu exercício, veda os atos de disposição do próprio corpo que impliquem diminuição permanente da integridade física, na tentativa de coibir a autolesão. ${ }^{568}$

Ressalva o legislador a licitude da diminuição permanente, se houver "exigência médica", a qual deve ser interpretada no sentido de indicação médica, pois “o médico jamais impõe ou exige a disposição do corpo. O que se pretende enunciar é que pode ser necessária, por indicação médica, a extração ou retirada de uma parte do corpo". 569

Antes, porém, de ingressar especificamente na análise da transexualidade à luz do art. 13, do Código Civil, cumpre pincelar o tratamento da cirurgia anteriormente à vigência do atual Código, quando não havia norma similar no direito brasileiro.

Em artigo titulado "Aspectos jurídicos do transexualismo", Aracy Klabin asseverou: "É nossa opinião que deve ser dado a esses indivíduos todo o tratamento médico possível, contudo não deve ser dada autorização para a cirurgia de alteração, a qual seria o ponto fatal de não-retorno". 570

A cirurgia para a mudança de sexo era considerada mutiladora e configurava, na anotação de Antonio Chaves, crime de lesão corporal gravíssima. ${ }^{571}$

A defesa da inexistência do delito de lesão corporal foi objeto de parecer do professor Heleno Claudio Fragoso, em ação penal movida contra o Dr. Roberto Farina, médico então acusado do crime previsto no art. 129, §2 , III, do Código Penal, por ter realizado, em dezembro de 1971, cirurgia de ablação dos órgãos sexuais de W. N., efetuando a abertura de uma fenda à imitação de vulva, para onde transplantou a uretra. $\mathrm{Na}$ lição do parecerista, o médico agira no exercício regular de direito, diante do consentimento do paciente e o interesse ou recomendação médica. ${ }^{572}$

Mesmo assim, anota Antonio Chaves que eram raros os acórdãos que afastavam a culpabilidade do médico, o que ocorria pela exclusão do dolo (RT 545/355), ou com base na excludente do exercício regular da profissão (CP, art. 23,

\footnotetext{
567 "Salvo por exigência médica, é defeso o ato de disposição do próprio corpo, quando importar diminuição permanente da integridade física, ou contrariar os bons costumes".

${ }_{568}$ PEREIRA, Caio Mario da Silva. Instituições de Direito Civil, cit., p. 250.

${ }^{569}$ Idem, mesma página.

${ }^{570}$ Revista de Direito da Universidade de São Paulo, vol. 90, 1995, p. 197.

${ }^{571}$ Direito à vida e ao próprio corpo, cit., p. 150.

${ }^{572}$ Revista de Direito Penal, nº 25, Rio de Janeiro: Forense, 1979, 25-34.
} 
III), em razão do interesse terapêutico e da necessidade da cirurgia para a saúde mental do paciente (RT 637/170).

Atualmente, a cirurgia vem sendo admitida no âmbito do art. 13, com base na ideia de que o direito ao corpo abrange a tutela da integridade psicofísica, vislumbrando-se na operação um tratamento definitivo e apto a diminuir o sofrimento do transexual, viabilizando sua inserção social. Para essa corrente, a transformação da genitália consiste no exercício do direito individual ao próprio corpo, que decorre do direito à personalidade, ao mesmo tempo que o direito à integridade física não está relacionado apenas à proteção anatômica externa do corpo humano, mas também é abarcado pelo direito à saúde, como sendo o direito de exigir que não se pratiquem atos contrários à saúde de uma pessoa e de exigir cuidados da sociedade e do Poder Público, em proteção à integridade e ao bem-estar para o pleno desenvolvimento da personalidade. ${ }^{573}$

Diante do fato objeto de regulação, do teor do art. 13, do Código Civil, e das lições da doutrina, percebe-se a necessidade de conjugar a pesquisa do jurista com a dos profissionais da saúde, no estabelecimento da extensão e dos limites ao exercício do direito ao corpo, em relação à cirurgia para mudança de sexo.

Na percepção de Maria Helena Diniz, o verdadeiro transexual é um doente, cuja dignidade deve ser respeitada. ${ }^{574} \mathrm{~A}$ autora afirma acreditar que o melhor tratamento seria a psicoterapia ou a psicanálise, a fim de adequar a mente aos atributos físicos do transexual. Contudo, descarta tal alternativa, assim justificando: "Todavia, tal técnica é, em regra, infrutífera, porque o transexualismo é incurável, já que constitui uma doença genética, provocada por defeito cromossômico ou fatores hormonais", 575 acrescentando ser a cirurgia a única solução, "porque o distúrbio é tão arraigado e a convicção do transexual tão imutável que o tratamento psicoterapêutico é inútill". 576

Anota Roxana Cardoso Brasileiro Borges, ao comentar os procedimentos de transgenitalização, que "tais cirurgias não são simples atos deliberados de disposição do próprio corpo. São intervenções médicas similares às demais que visam à preservação da saúde da pessoa, ainda que se trate da sua saúde psíquica". 577

Nessa medida, a intervenção corporal afigura-se possível, porque orientada pelos propósitos de cuidado e cura, consubstanciando o exercício do

\footnotetext{
${ }^{573}$ SZANIAWSKI, Elimar. Limites e possibilidades do direito de redesignação do estado sexual, cit., p. $78 / 81$.

${ }^{574} \mathrm{O}$ estado atual do biodireito, cit., p. 251.

575 O estado atual do biodireito, cit., p. 255.

${ }^{576}$ Idem, p. 256.

${ }^{577}$ Direitos da personalidade e autonomia privada. $2^{\text {a }}$ ed. São Paulo: Saraiva, 2007, p. 192.
} 
direito ao corpo dentro dos limites do ordenamento. A legitimidade ética da cirurgia, destarte, reside no princípio da autonomia do transexual, adulto e lúcido, de buscar por uma coerência entre seu corpo e seu espírito, considerado que na origem do pedido existe um sofrimento importante e persistente e não um mero capricho. ${ }^{578}$

Sob o ângulo da psicologia, as observações de Colette Chiland corroboram tal assertiva, ao apontar que os adultos transexuais se mostraram impermeáveis ao tratamento psicanalítico, pois para eles não há um "desejo" gerador de conflito, que possa ser trabalhado em análise, mas uma convicção de que pertencem ao outro sexo, dificultando a abertura da comunicação do terapeuta com o transexual. ${ }^{579}$ Por isso, relata que dificilmente os transexuais procuram um psicanalista e, quando o fazem, não há resultados efetivos, pois não se mostram abertos a explorar seu psiquismo de boa vontade e desejam atingir seu objetivo do modo mais rápido possível. ${ }^{580}$

Cumpre lembrar que os resultados terapêuticos da cirurgia têm sido comprovados, como atestado em pesquisa de campo realizada com pessoas que realizaram a operação, pelo Programa de transtorno de identidade de gênero do Hospital das Clínicas de Porto Alegre. O objetivo da pesquisa era investigar o impacto da cirurgia de redesignação de sexo na satisfação sexual dos pacientes, nos seus relacionamentos afetivos e em suas relações familiares.

O trabalho, publicado on line, revelou os seguintes resultados: nenhum dos dezenove pacientes (dezoito de homem para mulher e um de mulher para homem) se arrependeu de ter se submetido à cirurgia; para 83,3\% dos entrevistados houve uma melhora na experiência sexual após a cirurgia; 64,7\% informou maior facilidade para iniciar e manter uma relação afetiva; e 73,7\% declarou não ter notado diferença nos relacionamentos familiares.

A partir dos resultados, concluíram os médicos envolvidos: "Os resultados presentes indicaram que a cirurgia de redesignação de sexo apresentou efeitos positivos nas diversas dimensões da vida dos pacientes analisados: relacionamentos sexuais, parcerias afetivas e relações familiares" (tradução livre). ${ }^{581}$

578 HOTTOIS, Gilbert. MISSA, Jean-Nöel. Nova enciclopédia da bioética: medicina, ambiente e biotecnologia. Tradução de Maria Carvalho. Lisboa: Instituto Piaget, 2003. Verbete transexualismo, p. 652. ${ }^{579}$ O Transexualismo, cit., p. 38/40.

${ }^{580}$ Idem, p. 62 e p. 68.

581 "The present results indicate that SRS had a positive effect on different dimensions of the patients' lives in all three aspects analyzed: sexual relationships, partnerships and family relationships” in LOBATO, Maria Inês; KOFF, Walter José; MANENTI, Carlo; SEGER, Débora da Fonseca; SALVADOR, Jaqueline; FORTES, Maria da Graça Borges; PETRY, Analídia Rodolpho; SILVEIRA, Esalba; HENRIQUES, 
Autorizado afirmar, assim, a licitude da cirurgia, realizada mediante indicação médica, e seu afinamento com o princípio da dignidade da pessoa humana.

Maria Helena Diniz, baseada no estudo da legislação comparada, cita a previsão da realização da operação, sem que se cogite violação à integridade física, perante a legislação dos Estados Unidos, segundo a qual o requerimento para a intervenção deve ser acompanhado de declaração apresentada por advogado, eximindo o médico de responsabilidade por complicações futuras; e o entendimento da Comissão Europeia de Direitos do Homem, pelo qual a intervenção cirúrgica consiste em conversão curativa necessária para a integração pessoal e social do paciente ao sexo pretendido, julgando sequer existir perda de função, porque o órgão extirpado era inútil ao transexual. ${ }^{582}$

Daí porque a operação para a modificação do corpo, e não a transformação do sexo, ${ }^{583}$ passou a ser autorizada pelo Conselho Federal de Medicina do Brasil, desde 1997, admitida como "a etapa mais importante no tratamento de pacientes com transexualismo", de acordo com o quinto Considerando da Resolução no 1.955 , de 12/08/2010, do CFM.

Pela perspectiva médica, a transformação da genitália orienta-se pelo propósito terapêutico de adequação ao sexo psíquico, correspondendo à fase mais relevante do tratamento do paciente transexual, "portador de desvio psicológico permanente de identidade sexual, com rejeição do fenótipo e tendência à automutilação e/ou autoextermínio" (Resolução CFM n ${ }^{\circ} 1.955 / 2010$ ), do que resulta a previsão normativa da indicação médica necessária para a diminuição permanente do corpo no caso da transexualidade, nos moldes do art. 13, do Código Civil.

Em relação ao profissional, a mesma Resolução preocupou-se em afastar a existência de ilícito, nos termos de seu terceiro Considerando: "a cirurgia de transformação plástico-reconstrutiva da genitália externa, interna e caracteres sexuais secundários não constitui crime de mutilação previsto no artigo 129 do Código Penal brasileiro, haja vista que tem o propósito terapêutico específico de adequar a genitália ao sexo psíquico".

Alexandre Annes. Follow-Up of Sex Reassignment Surgery in Transsexuals: a Brazilian Cohort,in Arch Sex Behav (2006) 35:711-715 DOI 10.1007/s10508-006-9074-y, p. 714.

${ }^{582}$ DINIZ, Maria Helena. O estado atual do biodireito, cit., p. 260.

${ }^{583}$ SUTTER, Matilde Josefina. Determinação e mudança de sexo. Aspectos médico-legais. São Paulo: RT, 1993, p. 117. 
Pode-se reconhecer, nesse panorama, a licitude da cirurgia, sob o enfoque de atender ao requisito da exigência médica, como expresso no Enunciado $\mathrm{n}^{\circ}$ 276, do Centro de Estudos Judiciários do Conselho da Justiça Federal: “ O artigo 13, do Código Civil, ao permitir a disposição do próprio corpo por exigência médica, autoriza as cirurgias de transgenitalização, em conformidade com os procedimentos estabelecidos pelo Conselho Federal de Medicina, e a consequente alteração do prenome e do sexo no Registro Civil”.

\section{2.c) O pressuposto da indicação médica para a realização da} cirurgia: uma limitação à autonomia?

Indaga-se se, no caso da transexualidade, o condicionamento da prática de atos que impliquem diminuição permanente à exigência ou indicação médica seria um atentado à autonomia da pessoa, ou mesmo a negativa do direito ao corpo, cujo exercício estaria submetido à autorização de terceiros. Cumpre enfrentar a questão.

A interferência no corpo humano não é simples. No caso da transexualidade, a cirurgia pode trazer privação na experiência sexual, uma vez que pressupõe a perda irreparável dos órgãos naturais, sendo que a funcionalidade do órgão artificial não corresponde ao exato funcionamento de um órgão natural, constatando-se, em regra, uma insensibilidade sexual. ${ }^{584}$ Além disso, a intervenção nos hormônios torna a pessoa refém da vigilância médica por longo prazo, transformando um corpo saudável e órgãos sadios do ponto de vista físico e biológico em um corpo que passa a demandar cuidados e acompanhamentos antes desnecessários.

A técnica cirúrgica encontra limites em si mesma, persistindo dificuldades para a obtenção de bom resultado tanto no aspecto estético, quanto no funcional, das neofaloplastias, mesmo nos casos com boa indicação de transformação do fenótipo feminino para o masculino (décimo primeiro Considerando da Resolução CFM n ${ }^{\circ}$ 1955/2010). Em razão do estado da técnica, neste caso, a autorização para a realização da cirurgia ainda é dada somente a título experimental, (art. $2^{\circ}$, Resolução CFM n ${ }^{\circ}$ $1955 / 2010)$.

Nesse contexto, em que emergem as inconveniências do tratamento cirúrgico, a opção pela sua realização deve ser cercada de preparativos e cuidados, inclusive quanto às expectativas do paciente.

\footnotetext{
${ }^{584}$ SUTTER, Matilde Josefina. Determinação e mudança de sexo, cit., p. 116/117 e DINIZ, Maria Helena.
} O estado atual do biodireito, cit., p. 258. 
Observa Colette Chiland, a partir de sua experiência clínica no atendimento de transexuais, que a cirurgia tão desejada não necessariamente significa o fim do sofrimento do transexual, visto que é impossível transformar um homem em uma mulher, e vice-versa, no estágio atual da medicina. Conseguem-se alterações na aparência exterior, permitindo à pessoa viver como alguém do outro sexo, permanecendo, no entanto, a origem cromossômica do sexo oposto e o sofrimento de não possuir totalmente o corpo de um homem ou mulher. ${ }^{585}$

No Seminário Internacional de Identidade de Gênero e Transexualidade, realizado entre os dias 24 e 28 de setembro de 2001, em Valência, na Espanha, Colette Chiland, citada por Berenice Alves de Melo Bento, destacou, em sua conferência, o sucesso do tratamento clínico realizado em crianças, revelando, por outro lado, um índice elevado de pessoas arrependidas de terem se submetido à cirurgia, sem um anterior e rigoroso acompanhamento psicológico. ${ }^{586}$

Dois anos depois, ao escrever seu livro, a autora francesa concluiu: "Se o objetivo deles era viver como membro do outro sexo, essa meta é atingida. Se o objetivo era ser homem ou mulher completo, eles têm de enfrentar uma desilusão, até um desespero". 587

No mesmo sentido, o alerta de Stoller, lembrado por Catherine Millot, de que eventual erro de diagnóstico e submissão à cirurgia de alguém que não seja transexual pode "ter como consequência a descompensação psicótica dos pacientes após a operação". 588

Matilde Josefina Sutter admite ainda a possibilidade de suicídio da pessoa que não atinge suas expectativas após a cirurgia, salientando a preocupação de trabalhar tais expectativas antes da operação, para aproximá-las do que é possível e evitar idealizações. ${ }^{589}$

Nesse contexto, a avaliação pela equipe multidisciplinar e a exigência de indicação médica da cirurgia, no lugar de caracterizar violação da autonomia, volta-se a realizar o princípio da dignidade humana, de modo a proteger a pessoa em sua

\footnotetext{
${ }^{585}$ CHILAND, Colette. O transexualismo, cit., p. 30.

${ }^{586}$ BENTO, Berenice Alves de Melo. Da transexualidade oficial às transexualidades. In Piscitelli, Adriana; Gregori, Maria Filomena; Carrara, Sergio (orgs). Sexualidade e saberes: convenções e fronteiras, cit., p. 146.

${ }^{587}$ CHILAND, Colette. O transexualismo, cit., p. 59.

${ }^{588}$ MILLOT, Catherine. Extrasexo: ensaio sobre o transexualismo, cit., p. 44.

${ }^{589}$ Determinação e mudança de sexo, cit., p. 117/118.
} 
integridade físico-psíquica, somente procedendo-se à transformação corporal nas hipóteses de prognóstico favorável à expansão e ao desenvolvimento da personalidade do paciente.

Para essa avaliação, estabelece a norma administrativa a necessidade de que haja o desconforto com o sexo anatômico natural e a permanência do desejo de perder as características primárias e secundárias do próprio sexo e ganhar as do sexo oposto, por no mínimo dois anos, sem que exista doença mental, como critérios para a definição do transexualismo, nos moldes do art. $3^{\circ}$, da Resolução no 1955/2010. A seleção de pacientes para a cirurgia, de seu turno, obedecerá ao parecer da equipe multidisciplinar responsável pela avaliação, composta por médico psiquiatra, cirurgião, endocrinologista, psicólogo e assistente social, após no mínimo dois anos de acompanhamento conjunto, exigindo-se o diagnóstico de transexualismo, ser maior de 21 anos e a ausência de caracteres físicos inapropriados à cirurgia, nos termos do art. $4^{\circ}$, da Resolução $\mathrm{n}^{\circ}$ $1955 / 2010$.

O procedimento e o prazo determinados pela Resolução acabam facilitando a distinção entre o transexual primário e o secundário, tratando-se de diagnóstico de relevante importância, considerando que somente ao transexual primário está indicada a cirurgia, haja vista que no transexual secundário o desejo de mudança é transitório. Bem por isso, afirma Colette Chiland que, quanto menos primário o transexual, menos satisfatórios serão os resultados da operação. ${ }^{590}$ Os transexuais primários correspondem a $20 \%$ dos casos que buscam esse tratamento, de acordo com Roberto Farina, citado por Antonio Chaves. ${ }^{591}$

É verdade que atribuir a terceiros a avaliação da pessoa em tal profundidade, para proceder ao diagnóstico sobre a indicação da cirurgia, não é algo simples, deixando-se a cargo dos profissionais da saúde, humanos e passíveis de falhas, a decisão sobre a possibilidade de realizar a operação. Na sensível percepção de Maria de Fátima Freire de Sá e Bruno Torquato de Oliveira Naves, "muitas vezes, a pessoa procura comportar-se de acordo com os padrões que a sociedade exige (sexo educacional?), na tentativa de superar seus anseios e preferências. Sabe-se lá por quais experiências podem se sujeitar na tentativa de não desagradar a quem quer que seja...", 592 o que poderia dificultar a avaliação e resultar na indevida negativa de indicação cirúrgica. Com base no argumento do respeito e proteção da pessoa contra a pressão para corresponder aos padrões

${ }^{590}$ CHILAND, Colette. O transexualismo, cit., p. 57.

${ }^{591}$ Direito à vida e ao próprio corpo (intersexualidade, transexualidade, transplantes), cit., p. 144.

592 SÁ, Maria de Fátima Freire de. NAVES, Bruno Torquato de Oliveira. Transexualismo. In Manual de Biodireito. Minas Gerais: Del Rey, 2009, p. 256. 
sociais, destarte, sustentam os respeitados professores mineiros a prevalência do desejo de transformar o corpo, ainda que não manifestado de forma estável, como a melhor alternativa para a proteção da dignidade do transexual.

Diante da complexidade do ponto, refletir sobre os reflexos da cirurgia pode auxiliar no desate da questão. Antes, porém, cabe consignar a impotência sentida por aqueles que diretamente lidaram com pessoas transexuais, de modo a não perder de vista os limites da medicina na solução do conflito de identidade.

Na citação de Colette Chiland, forte na lição de Stoller: "a regra que aplicamos ao tratamento do transexual é: o que quer que façamos - e mesmo que não façamos nada - seremos culpados". ${ }^{593}$ Semelhantes os resultados encontrados na pesquisa realizada pelo Programa de Transexuais e Identidade de Gênero (PROTIG), do Hospital das Clínicas de Porto Alegre, publicada sob o título "Aplicação do Defensive Style Questionnaire para avaliar o impacto da cirurgia de redesignação sexual nos mecanismos de defesa de pacientes transexuais". ${ }^{594}$ Tal pesquisa trouxe informações sobre o impacto da cirurgia de redesignação de sexo nos mecanismos de defesa dos pacientes, ou seja, nos mecanismos psicológicos indicativos de como a pessoa usualmente lida com seus conflitos, resultante na classificação das personalidades em madura, neurótica e imatura. Os pesquisadores submeteram trinta e dois pacientes a um questionário na data de seus ingressos no Programa e doze meses depois da cirurgia de redesignação de sexo. Objetivavam apurar se a significativa melhora na vida dos pacientes transexuais após a cirurgia, afirmada na literatura médica e confirmada pela prática clínica, alterava os estilos de defesa dos pacientes. Seus resultados foram negativos, concluindo que a transformação corporal não melhora aspectos psicológicos referentes ao modo como a pessoa organizou sua personalidade. Uma explicação aventada para isso baseia-se na limitação da cirurgia para resolver a disforia de gênero. Para os pesquisadores, embora a intervenção corporal diminua o sofrimento psicológico da pessoa, não tem o condão de curar a desordem de identidade de gênero, que remonta a estruturas primárias e infantis dos pacientes.

Assim, com base nos resultados das pesquisas do PROTIG, extrai-se que a cirurgia não necessariamente alcança o conflito identitário em seu âmago e, por isso, não teria o condão de apaziguar o sujeito, persistindo um certo desconforto íntimo e pessoal mesmo após a intervenção.

\footnotetext{
${ }^{593}$ CHILAND, Colette. O transexualismo, cit., p. 51.

${ }^{594}$ Revista Brasileira de Psiquiatria, 2009, 31(4), p. 303/306.
} 
Trata-se do ponto fulcral para a análise da questão sobre a melhor forma de proteção da dignidade do transexual. Ao que parece, admitidos os limites da cirurgia como forma de tratamento do conflito de identidade e assumida a premissa de que a operação pode não atingi-lo, a discussão sobre a forma mais efetiva de proteção da dignidade desloca-se do plano do direito ao corpo e alcança o nível relacional de respeito à identidade, que será oportunamente aprofundado, por ocasião da proposta de reconhecimento do direito à identidade de gênero, no último capítulo.

Cumpre, então, renovar a indagação que abre este item sobre a preservação, ou não, da autonomia, ao se exigir uma indicação médica como condição para o exercício do direito ao corpo no caso da mudança do sexo. Vejamos.

A autonomia e o direito ao corpo estão inseridos num contexto jurídico normativo orientado pelo princípio da dignidade da pessoa humana, cujas linhas mestras atuam ao mesmo tempo como norte e limite. No caso da transexualidade, há aspectos cirúrgicos que escapam da área de conhecimento dos juristas, tratando-se de discussão travada no âmbito da interdisciplinariedade. Como visto, do ponto de vista da saúde, a cirurgia de redesignação corporal pode trazer inconvenientes e frustrações funcionais, não se podendo garantir a transformação absoluta de um homem em uma mulher, e vice-versa. Por isso, os custos e benefícios da cirurgia para determinada pessoa são analisados pela equipe multidisciplinar pelo prazo de dois anos, antes do diagnóstico e da indicação da cirurgia, com vistas a atenuar os riscos inerentes a qualquer intervenção na natureza e, inclusive, o arrependimento da pessoa.

Nesse contexto, quer parecer, a exigência médica coaduna-se com a tutela da dignidade, evitando expor o indivíduo a um aumento de angústia por inadequação ao gênero de identificação.

Por outro lado, dada a extensão dos efeitos sociais e jurídicos advindos da operação de mudança de sexo, sustentável que apenas seja realizada em caso de necessidade para o alívio do sofrimento humano, em casos típicos, evitando-se a banalização ou a exploração econômica do que se poderia tornar uma demanda caprichosa.

Tampouco se vislumbra no art. 13, do Código Civil, uma transferência ao médico do problema jurídico relativo aos limites da disposição sobre o próprio corpo no que toca à cirurgia para mudança de sexo.

Isso porque, para o diagnóstico da transexualidade, faz-se necessária a avaliação de aspectos cirúrgicos, sociais e psicológicos, que os juristas não são aptos a proceder, reconhecendo-se a importância da reunião de esforços entre as diversas 
áreas do conhecimento para a indicação do tratamento, sempre com vistas à melhor realização da dignidade da pessoa no caso concreto.

Nesse sentido, reitera-se a previsão da atuação de uma equipe multidisciplinar, composta por psicólogos e assistentes sociais entre outros profissionais, que acompanha a pessoa durante o período de dois anos (art. $4^{\circ}$, Resolução Conselho Federal de Medicina $\mathrm{n}^{\mathrm{o}}$ 1.955/2010), procedendo a um diagnóstico conjunto que não se restringe ao parecer do médico.

Acrescenta-se que a exigência do diagnóstico por profissionais especializados se faz presente nos países que legislaram sobre a mudança de nome e sexo decorrente da transexualidade, como a Espanha (Lei $n^{\circ}$ 03/2007), a Inglaterra (Recognition Gender Act, de 2004) e Portugal (Lei no 07/2011), justificada na lei pela preocupação de zelar pela segurança e irreversibilidade da alteração, referindo-se, portanto, a aspectos eminentemente jurídicos.

Destarte, entende-se que a exigência médica como condição para a realização da cirurgia não implica a violação da autonomia nem a transferência de problemas jurídicos à medicina. Trata-se de condição inserida na lei pelo reconhecimento dos limites do Direito para lidar com as técnicas próprias da área da saúde.

Nesse passo, cumpre lembrar com Foucault a relação que se estabelece entre o conhecimento - o saber, o poder e o prazer, ${ }^{595}$ alertando-se para a sedução do poder da ciência pretensamente capaz de responder ao problema colocado, o que se aplica tanto à medicina, quanto ao direito. No caso do transexual, ao que parece, à medicina cabe o cuidado com a saúde da pessoa, enquanto ao direito, a regulação dos efeitos jurídicos daí decorrentes, sempre objetivando a dignidade da pessoa acima de qualquer outro interesse.

\section{2.d) $\mathrm{O}$ direito ao corpo e a ofensa aos bons costumes}

Por fim, para encerrar o estudo do art. 13, do Código Civil brasileiro, cumpre mencionar o segundo limite legal ao exercício do direito ao corpo.

Adriano De Cupis, ao tratar especificamente da limitação à integridade física decorrente dos bons costumes com base no art. $5^{\circ}$, do Código Civil

\footnotetext{
${ }^{595}$ História da Sexualidade. I A vontade do saber. Tradução de Maria Thereza da Costa Albuquerque e J.A. Guilhon Albuquerque. $2^{\text {a }}$ ed. Rio de Janeiro: Edições Graal, 1979, p. 16/17.
} 
Italiano de $1942,{ }^{596}$ que posteriormente inspirou o legislador brasileiro na dicção do art. 13, do Código Civil, assim sintetizava o ponto: "O consentimento é também inválido se for contrário <<aos bons costumes〉> ou, por outras palavras, às normas morais consideradas como tais pela opinião comum em um dado momento". 597

A doutrina pátria, no comentário ao art. 13, na mesma direção afirma proibidas as disposições do corpo que ofenderem "às práticas e condutas costumeiras que são adotadas e respeitadas por um grupo social, conforme sejam os padrões morais e éticos de comportamento predominantes em dada época". 598

No século passado, a diminuição permanente do corpo para a transformação da aparência do sexo era vista como atentatória aos bons costumes. Sustentava De Cupis a invalidade do consentimento das transplantações de glândulas genitais, por se tratar de diminuição permanente com perda da aptidão para gerar, contrária à moral corrente e às exigências demográficas do Estado. ${ }^{599}$

Na atualidade, a compreensão da cirurgia de mudança de sexo como tratamento necessário ao alívio de um sofrimento tem contribuído para a percepção de que não há ofensa ou exercício ilegítimo do direito ao corpo, nem ofensa aos bons costumes.

Como lembrou Suzana Almeida, citando julgamento da Corte Europeia de Direitos Humanos de 2002, o Tribunal vislumbrou "uma tendência internacional contínua não apenas no sentido de uma crescente aceitação social dos transsexuais, mas igualmente no sentido do reconhecimento jurídico da nova identidade sexual dos transexuais operados". 600

A exigência de autorização médica, outrossim, indica que a cirurgia de transgenitalização, objetivando a integridade psicofísica do paciente e o cuidado com sua saúde, não se insere entre os atos rotineiros e cotidianos que se cristalizam em costumes.

Por isso, sob o limite dos bons costumes, a operação para a mudança de sexo não deve ser considerada atentatória contra a legalidade, como já afirmado no item 6.2, sob o aspecto do livre desenvolvimento da personalidade.

\footnotetext{
596 "Gli atti di disposizione del proprio corpo sono vietati quando cagionino una diminuzione permanente della integrità fisica o quando siano altrimenti contrari alla legge, all'ordine pubblico o al buon costume".

${ }_{597} O$ direito à integridade física. In Os direitos da personalidade, cit., p. 75.

598 MONTEIRO FILHO, Raphael de Barros e outros. TEIXEIRA, Sálvio de Figueiredo (coord). Comentários ao novo código civil: das pessoas. Vol I. Rio de Janeiro: Forense, 2010, p. 168.

${ }^{599}$ DE CUPIS, Adriano. O direito à integridade física. In Os direitos da personalidade, cit., p. 77/78.

${ }^{600} \mathbf{O}$ respeito pela vida (privada e) familiar na jurisprudência do Tribunal Europeu dos Direitos do Homem: a tutela das novas formas de família, cit., p. 237.
} 


\section{3) As pretensões de mudança de nome e sexo}

Após a transformação da aparência da pessoa transexual, ponto que foi abordado sob o ângulo do direito ao corpo, torna-se necessário ingressar nos demais aspectos jurídicos dessa mudança. Como anota Matilde Josefina Sutter, "o transexual então modificado, quer ser aceito socialmente e isto implica na compatibilização do novo físico com o seu sexo jurídico". ${ }^{601}$

No plano do direito, as primeiras pretensões dos transexuais referem-se às mudanças do nome e do sexo no registro civil, sem as quais não se completa o processo de inclusão iniciado pelo tratamento realizado pelos profissionais da saúde.

Há casos em que a mudança jurídica é inclusive o objetivo principal visado pela pessoa, que acaba submetendo-se à intervenção cirúrgica apenas porque premida pela necessidade de ter juridicamente reconhecido seu nome e sexo de identificação. De fato, considerando que a primeira e mais importante necessidade humana emotivo-afetiva consiste na necessidade de ser aceito e reconhecido no processo de surgimento da identidade, ${ }^{602}$ explica-se a importância do reconhecimento jurídico do nome e da identidade de gênero do transexual.

A relevância dessa regularização jurídica é descrita por Catherine Millot. A psicanalista, a partir de entrevistas com transexuais femininos e masculinos, consignou: "Depois de lutar para ver reconhecido seu desejo de mudança de sexo e para obter os certificados psiquiátricos necessários, depois dos sofrimentos das múltiplas operações, depois de todo tipo de dificuldade com a família, com o campo profissional para que aceitassem sua escolha, precisaria ainda lutar para conquistar a mudança do sexo civil que seria, por assim dizer, o coroamento de todo o seu empreendimento". 603

No mesmo sentido, a conclusão dos profissionais da saúde do programa de tratamento de transexuais do Hospital das Clínicas de Porto Alegre, para quem o processo de adaptação social do transexual envolve, além da medicina, aspectos relacionados ao direito, essenciais à facilitação de emprego e escolarização. Segundo a pesquisa, o processo de inclusão dos transexuais pressupõe a reinserção da pessoa ao corpo social, visto que muitos abandonaram a família e a escola para evitar o preconceito. Nesse contexto, a alteração da identidade apresenta-se como necessária para que o paciente seja

\footnotetext{
${ }^{601}$ Determinação e mudança de sexo, cit., p. 116 .

602 VERDE, Jole Baldaro, GRAZIOTTIN, Alessandra. O enigma da identidade: o transexualismo. Tradução de Sérgio Schirato. São Paulo: Paulus, 1997, p. 22.

${ }^{603}$ MILLOT, Catherine. Extrasexo: ensaio sobre o transexualismo, cit., p. 101/102.
} 
integrado à sociedade, sem o que tenderia a permanecer excluído mesmo após a operação. ${ }^{604}$ Para os profissionais envolvidos, a principal contribuição do programa, além do tratamento em si, consiste em sensibilizar as autoridades para a importância de providenciar uma nova identidade aos indivíduos operados e em assegurar o acesso gratuito à cirurgia. ${ }^{605}$

A necessidade de adequação do estado civil à nova conformação física para permitir a inclusão efetiva da pessoa na sociedade também é apontada por Colette Chiland. Segundo a autora, a experiência clínica revela que, antes da mudança do documento de identidade, alguns pacientes não chegam a ter uma vida profissional regular, em razão dos problemas criados pela documentação em desacordo com a aparência, enfrentando vários constrangimentos na vida cotidiana. ${ }^{606}$

Tais percalços, no exemplo de Berenice Bento, envolvem as situações em que somos chamados a nos identificar, como na obtenção de um cartão de crédito, realização de uma matrícula ou participação em seleção de emprego, afirmando: "Para quem vive esse tipo de experiência, essa lacuna legal é trágica". 607

A criação de um estatuto intermediário, terceiro sexo, talvez não resolvesse o problema, pois, majoritariamente, o transexual pede para ser acolhido em um dos sexos existentes, "sem ser estigmatizado por não satisfazer todos os critérios do estado de macho ou do estado de fêmea". 608

No âmbito da técnica jurídica, a pretensão revelada insere-se especificamente nos direitos ao nome e ao sexo, envolvendo a possibilidade da respectiva mudança. Inclui também o registro civil, naquilo que torna públicos os dados pessoais, questão que, por metodologia, será abordada sob o ângulo dos reflexos da identidade sexual.

\footnotetext{
604 "The process of social adaptation of transexual patients involves several biopsychosocial variables. The first aspect to be consideres is the feasibility of changin the patient's legal identity, which facilitates regular employment and enrollment in school programs, in addition to decrasing the feeling of shame often associated with this condition. This is particulary important, since the prejudice against transexuals often leads them to abandon their families early and avoid formal education. Thus, many have never received technical or professional training and are socially excluded”. in Lobato, Maria Inês; Koff, Walter José; Manenti, Carlo; Seger, Débora da Fonseca; Salvador, Jaqueline; Fortes, Maria da Graça Borges; Petry, Analídia Rodolpho; Silveira, Esalba; Henriques, Alexandre Annes. Follow-Up of Sex Reassignment Surgery in Transsexuals: a Brazilian Cohort,in Arch Sex Behav (2006) 35:711-715 DOI 10.1007/s10508-006-9074y, p. 714.

605 Idem, p. 715.

${ }^{606}$ CHILAND, Colette. $O$ transexualismo, cit., p. 57.

607 Identidade Legal de Gênero: Reconhecimento ou autorização? In COSTA, Horácio e outros (org) Retratos do Brasil Homossexual. Fronteiras, subjetividades e desejos. São Paulo: Editora da Universidade de São Paulo: Imprensa Oficial, 2010, p. 72.

${ }^{608}$ CHILAND, Colette. O transexualismo, cit., p. 89.
} 
No mais, vale anotar que não se pretende o esgotamento dos conteúdos dos direitos da personalidade atinentes ao nome e ao sexo, limitando-se a abordagem aos aspectos relevantes para tornar efetivo e concreto o princípio da dignidade humana em relação às pessoas transexuais.

\section{3.a) O direito ao nome e a possibilidade de alteração do} prenome, em consequência da transexualidade

O nome destaca-se entre os direitos da personalidade que auxiliam na individualização do ser humano. Pela legislação brasileira, compreende o prenome e o sobrenome (art. 16, Código Civil).

Na definição de De Cupis, "é o sinal verbal que identifica imediatamente e com clareza a pessoa a quem se refere", tornando possível a identificação da pessoa mesmo na sua ausência. ${ }^{609}$ Ensina o autor que a particular importância social e jurídica atribuída ao nome decorre de sua função de individualizar e identificar o sujeito, ao que conclui: "o ordenamento jurídico toma em consideração a função identificadora do nome e confere a este uma tutela particular; e tanto é assim que o direito à identidade pessoal se configura, essencialmente, como direito ao nome". 610

No direito civil moderno, voltado à realização do indivíduo, a relevância do nome deixou de ancorar na indicação do pertencimento à determinada família, passando a constituir "o anteparo da identidade da pessoa, a sede do seu amor próprio". 611

No direito romano vigorava o princípio da mutabilidade do nome, que cedeu perante o interesse público de identificar as pessoas em sociedades mais complexas e numerosas. ${ }^{612}$ Daí porque, na atualidade, afirmar-se o princípio da imutabilidade do nome, vedando alterações arbitrárias.

Em que pese o regime da não liberdade em relação à mudança do nome, tal não se confunde com a absoluta impossibilidade de alteração, existindo situações em que a própria lei a autoriza.

Trata-se das hipóteses do art. 55 ao art. 58, da Lei dos Registros Públicos, sob as quais, por exemplo, vedam-se registros de prenomes suscetíveis de expor

\footnotetext{
${ }^{609}$ O direito à identidade pessoal. In Os direitos da personalidade, cit., p. 165.

${ }^{610}$ Idem, p. 166.

${ }^{611}$ MORAES, Maria Celina Bodin de. A tutela do nome da pessoa humana. In Na medida da pessoa humana, cit., p. 152.

${ }^{612}$ DE CUPIS, Adriano. O direito à identidade pessoal. In Os direitos da personalidade, cit., p. 168.
} 
a pessoa ao ridículo (art. 55, par. único), autorizando o ingresso de ação para a retificação, e permite-se a substituição do prenome, em caso de fundada coação ou ameaça decorrente da colaboração para a apuração de crime (art. 58, caput e par. único).

Na avaliação de Maria Celina Bodin de Moraes, a mitigação da regra da imutabilidade do prenome justifica-se pelo princípio da dignidade da pessoa humana, de modo a garantir uma real e adequada identificação da pessoa pelo nome. A partir daí, constata a professora um alargamento da exceção da "exposição ao ridículo", a ser entendida em sentido mais amplo, "como representativa do que não é condigno da individualização da personalidade humana". 613

$\mathrm{Na}$ transexualidade, caracterizada por um conflito de identidade com intensas repercussões na identificação da pessoa em sociedade, a possibilidade de alteração do nome ganha especial relevo. De fato, consistindo o nome uma forma de expressão da identidade, de rigor que corresponda à aparência da pessoa individualizada, evitando-se impor o constrangimento de identificar por Maria alguém que se assemelha a João, e vice-versa.

Assim, porque o prenome atribuído na ocasião do nascimento deixou de corresponder à imagem e ao modo pelo qual a pessoa passou a ser conhecida, torna-se necessária sua mudança, a fim de zelar para que mantenha sua função de identificação e projeção da identidade de seu titular.

Nesses moldes, a alteração do prenome do transexual não deve ser considerada arbitrária. Ao contrário, conecta-se diretamente com o princípio da dignidade humana, evitando expor a pessoa ao ridículo, mantendo a coerência entre o nome e a aparência do sujeito referido.

Bem por isso, na lição de Limongi França, são causas que autorizam a alteração do prenome, entre outras, a mudança de sexo ou o reconhecimento de sexo diverso, além da não correspondência do assento com a declaração, o uso de nome diverso, a sentença judicial em ação de estado, ou prenome ridículo, ${ }^{614}$ igualmente aplicáveis à situação do transexual.

No mesmo sentido, a lição de Sílvio de Sálvio Venosa. O autor, após apontar que a questão do nome do transexual se desloca para o plano constitucional da cidadania e da dignidade da pessoa humana, conclui: "Desse modo, a alteração do

\footnotetext{
${ }^{613}$ MORAES, Maria Celina Bodin de. A tutela do nome da pessoa humana. In Na medida da pessoa humana, cit., p. 167.

${ }^{614}$ Do nome civil das pessoas naturais, p. 259 a 290.
} 
prenome para o sexo biológico e psíquico reconhecido pela Medicina e pela Justiça harmoniza-se com o ordenamento, não só com a Constituição, mas também com a Lei dos Registros Públicos, não conflitando com seu art. 58".615

Os Tribunais, sensíveis à situação da pessoa transexual, têm se mostrado majoritariamente favoráveis à alteração do nome (TJ/MG - $7^{\mathrm{a}}$ Câmara Cível, Apelação n 1.0024.05.778220-3/001, Belo Horizonte, Rel. Wander Marotta, j. 6/3/2009, v.u.).

Dada a clareza e síntese, válida a transcrição da seguinte Ementa: "O prenome social será imutável, desde que melhor não atenda ao interesse coletivo a sua modificação. Se a imutabilidade do prenome foi preceituada em função da ordem pública, também em função da ordem pública deve ser excepcionada" (Apelação no 216.310-1, da 2 Câmara Civil, Tribunal de Justiça de São Paulo, Rel Lino Machado).

Cumpre também citar precedente em que autorizada a alteração do nome de pessoa transexual não operada, sinalizando uma facilitação dessa modificação. Nas palavras da Relatora Maria Berenice Dias, "O nome das pessoas, enquanto fator determinante da identificação e da divulgação de alguém a um determinado grupo familiar, assume fundamental importância individual e social". ${ }^{616}$ Nas circunstâncias, o órgão colegiado entendeu desnecessária a prova das situações vexatórias experimentadas pelo transexual, presumindo seu constrangimento e autorizando a mudança do nome para adequá-lo à aparência do demandante.

No mais, os julgados relativos à alteração do nome, em sua maioria, debruçam-se também sobre a mudança de sexo, o que recomenda uma análise conjunta.

Para tratar da possibilidade de alteração do sexo, por sua vez, necessário antes tecer breves considerações sobre o estado da pessoa.

\section{3.b) Breves considerações sobre o estado civil e a} possibilidade de alteração do sexo do transexual

O estado civil apresenta-se como um conjunto unitário que traduz a posição jurídica da pessoa nos planos individual (idade, sexo, saúde), familiar

\footnotetext{
${ }^{615}$ VENOSA, Sílvio de Sálvio. Direito civil: parte geral. 10a ed. São Paulo: Atlas, 2010, p. 198. ${ }^{616}$ TJRS - Acórdão 70013909874, j. 5/04/2006, 7ª Câmara Cível - p. 5. A decisão autorizou a mudança do prenome por unanimidade e rejeitou a mudança do sexo, por maioria.
} 
(cônjuge ou parente) e político (nacional e estrangeiro). ${ }^{617} \mathrm{O}$ sexo, ao lado do nome, insere-se entre as qualificações pelas quais a pessoa passa a se autoidentificar e ser identificada na sociedade.

Na lição de Orlando Gomes, “o status é uma qualidade jurídica decorrente da inserção de um sujeito numa categoria social, da qual derivam, para este, direitos e deveres", ${ }^{618}$ apontando que, "no fundo, o estado é uma qualificação, que encerra elementos de individualização da personalidade" ${ }^{619}$

Hottois consigna a relevância da esfera psíquica, além da físicobiológica, para a qualificação e individualização da pessoa. Seu conceito de estado inclui o elemento psicológico: “O estado civil também é uma estrutura de base da personalidade individual no plano psicológico e não apenas do indivíduo enquanto sujeito de direito", 620 acrescentando que a identidade sexual, que está em foco no enfrentamento da questão do transexual "é, ao mesmo tempo, uma realidade física (genética, fisiológica) e também simbólica (psicológica, comportamental, jurídica e social)". ${ }^{621}$

A indisponibilidade que caracteriza o estado civil não se confunde com imutabilidade, podendo ser alterado na forma prevista em lei. Assim, o nacional pode tornar-se estrangeiro, o solteiro, casado e este, divorciado. Contudo, como alerta Francisco Amaral, são vedadas alterações arbitrárias, já que a característica da indisponibilidade do estado decorre da necessidade de segurança e estabilidade jurídicas da estrutura social e familiar da pessoa. ${ }^{622}$

Por outro lado, o estado de uma pessoa é suscetível de posse, admitindo-se a posse de estado. Na lição de Francisco Amaral, a posse de estado é a aparência do direito, uma situação de fato em que o sujeito se comporta como se realmente o tivesse, gerando efeitos e tutela jurídicos: “A posse de estado é, assim, o exercício constante e público dos atos próprios de tal estado, é a situação aparente de uma pessoa". ${ }^{623}$ Para tanto, são necessários três elementos: nomen, tratactus e fama, valendo explicitar: "Nomen é o fato de a pessoa apresentar um nome correspondente ao estado que pretende ter. Tratactus é o fato de a pessoa ser considerada correspondente a esse estado.

\footnotetext{
${ }^{617}$ GOMES, Orlando. Introdução ao Direito Civil, cit., p. 150/152.

${ }^{618}$ Idem, p. 150.

${ }^{619}$ Idem, mesma página.

${ }^{620}$ HOTTOIS, Gilbert. Verbete transexualismo, na Enciclopédia de bioética, p. 652.

${ }^{621}$ Idem, p. 653.

${ }^{622}$ AMARAL, Francisco, Direito Civil. Introdução, cit., p. 275.

${ }^{623}$ Idem, p. 277.
} 
Fama, o conhecimento, o conceito de que desfruta em sociedade, correspondente ao estado que apresente". 624

Acrescenta o autor que não basta possuir para adquirir um estado, razão pela qual a função da posse é meramente probatória, sendo necessário o ajuizamento de ação, a fim de criar, modificar, extinguir ou defender o estado da pessoa natural. ${ }^{625}$ No caso da mudança de sexo decorrente da transexualidade, a ação classifica-se como constitutiva, por constituir um novo estado.

A partir das lições supra, autorizado afirmar a possibilidade de modificação do sexo do transexual, no pressuposto de que não se trata de mudança arbitrária.

De fato, assumida a modificação da aparência da pessoa como tratamento em prol de sua integridade psicofísica, a adequação do estado à nova imagem consiste na efetivação da tutela da saúde do transexual, justificada, portanto, por razões de ordem pública que afastam qualquer conotação de arbitrariedade.

Cabe lembrar que os estudos realizados com transexuais em outras áreas de conhecimento, por médicos, psicólogos, sociólogos e assistentes sociais, revelam a importância da readequação jurídica do estado ao gênero de identificação da pessoa, sem a qual fica difícil o compartilhamento da vida pública, não se completando o processo de inclusão social. Assim, torna-se necessário, sob o ângulo do direito, proceder à alteração do estado civil, na proteção jurídica da mesma integridade psicofísica, cuja tutela ensejou a mudança da aparência do transexual.

Diante das consequências da transexualidade, outrossim, parece difícil defender uma inflexibilidade do estado no que toca à mudança de sexo. Tal porque, sendo o estado civil uma qualidade jurídica individualizante da personalidade, não é razoável que se torne instrumento de constrangimento e apreensão em um ordenamento que fixa na pessoa humana seu mais alto ponto de proteção. Ao contrário, a qualificação estabelecida pelo estado tanto mais adequada será quanto melhor corresponder à estrutura de base da personalidade individual, inclusive no plano psicológico. Daí afirmar que a imutabilidade do estado, justificada pela necessidade de segurança da sociedade, deve ceder na hipótese em que sua alteração for motivada pela proteção de um interesse superior da mesma sociedade, qual seja, a dignidade da pessoa.

\footnotetext{
${ }^{624}$ Idem, p. $277 / 278$.

${ }^{625}$ Idem, p. 278.
} 
Por isso, a melhor compreensão da noção de estado civil à luz do princípio da dignidade da pessoa humana é aquela que promove o desenvolvimento da personalidade, permitindo a alteração do sexo do transexual, de modo a viabilizar a adaptação jurídica à identidade psíquica e à aparência do indivíduo.

Para a segurança jurídica, importante ponderar que a imutabilidade do sexo pouco contribuiria, diante da perplexidade causada pela disparidade entre a aparência e a documentação do transexual. Ademais, a possibilidade de mudança do estado civil não é inédita, admitida inclusive com base na posse de estado, situação fática aplicável aos transexuais, que aparentam e se comportam nos padrões próprios do gênero de identificação, de forma estável, passando a ser conhecidos e tratados como pertencentes ao sexo oposto. Por isso, sopesadas, de um lado, a dificuldade individual daquele que não é reconhecido juridicamente pelo que sente e aparenta e, de outro, a segurança jurídica que se pretende pela imutabilidade do sexo, a conclusão a que se chega é pela admissão da alteração, em benefício da própria estabilização das relações sociais.

A jurisprudência nacional majoritária tem admitido a alteração do nome e do sexo do transexual, de modo a adequá-los à identidade de gênero e à aparência da pessoa, com base no princípio da dignidade humana.

Verifica-se essa tendência igualmente no plano internacional, como se verá pela orientação da Corte Europeia de Direitos Humanos, fixada em precedente de 2002, que será analisada em capítulo próprio.

Podem ser referidas várias decisões judiciais em que deferida a alteração de nome e sexo do transexual operado (TJ/RJ, Ap. Cível no 001479003.2008.8.19.0002, 7ª Câmara Cível, Rel. Luciano Rinaldi, j. 20/07/2011; TJ/MG, Ap. Cível no 1.0024.09.672096-6/001, Rel. Alvim Soares, j. 27/04/2010; TJ/SP - Ap. Cível 427.435-4/3, 10 Câmara de Direito Privado, Rel. Maurício Vidigal, j. 11/11/2008, v.u; TJRS - Ap. Cível 70022952261, 8 a Câmara Cível, Rel. José Ataídes Siqueira Trindade, j. 17/04/2008; TJSP - Ap. Cível 430.069-4/0-00, $8^{\text {a }}$ Câmara de Direito Privado, Rel. Caetano Lagrasta, 23/05/2007; TJ/RJ - Apelação Cível no 1910/2005, 4ª Câmara Cível, Rel. Luis Felipe Salomão, j. 13/09/2005).

A seguir, são trazidos os fundamentos de algumas decisões, apenas a título de ilustração de como a jurisprudência vem reconhecendo a conexão entre a dignidade humana e a alteração do nome e do estado, bem como a importância dessa mudança para a pessoa. 
Em acórdão relatado pelo desembargador Fernando Antonio Maia da Cunha, reformando decisão de primeiro grau que havia negado a pretensão, o Tribunal de São Paulo autorizou a modificação do nome e do sexo da pessoa no registro civil. Nas palavras do relator, após reconhecer a realidade da cirurgia de redesignação de sexo em evolução dos costumes e da medicina: "Ocorre que a adequação física e social acarreta a necessidade da adequação jurídica, com a conseqüente modificação do nome e estado civil de quem por opção própria tem seu sexo redesignado. A providência e seu cabimento decorrem do princípio da dignidade da pessoa humana, viga mestra do nosso ordenamento jurídico $\left(\mathrm{CF} / 88\right.$, artigo $1^{\circ}$, III), na medida em que causa estranheza e desconforto que alguém se apresente como mulher quando seus documentos evidenciam nome e sexo masculino, e vice-versa" (Apelação Cível nº 619.672-4/9, 4ª Câmara TJ/SP, Rel Des Fernando Antonio Maia da Cunha, j. 19/02/2009, v.u.).

O Tribunal de Justiça do Estado do Rio de Janeiro, no mesmo sentido, admitiu a alteração do prenome e do sexo no registro civil, fazendo constar a “conveniência e necessidade de se ajustar a situação defluente das anotações registrais com a realidade constatada, de modo a reajustar a identidade física e social da pessoa com a que resulta de aludido assentamento" (Apelação Cível 0012229-64.20038.19.0007 (2005.001.17926), 18 ${ }^{\mathrm{a}}$ Câmara Cível, v.u., Rel. Des. Nascimento Povoas Vaz, j. $22 / 11 / 2005)$.

Enfatizando a necessidade da alteração do prenome e do sexo para o desenvolvimento da personalidade, as palavras do desembargador Elliot Akel: “Uma vez que a Constituição Federal de 1988 reconhece a existência de um direito geral ao livre e pleno desenvolvimento da personalidade humana, negar ao portador de disforia do gênero o direito à adequação do sexo morfológico e o sexo psicológico e a consequente redesignação do estado sexual e do prenome no assento de nascimento acaba por afrontar a lei fundamental" (JTJ 251/172).

A partir daí, permitido encerrar este item com uma conclusão favorável à possibilidade de mudança do prenome e do estado civil da pessoa transexual, em proteção de sua dignidade, como reconhecido pela jurisprudência. 


\section{V) O DIREITO À IDENTIDADE DE GÊNERO OU}

SEXUAL

\section{1) A abertura dos direitos da personalidade como emanações} da pessoa humana: a possibilidade de identificação de novos direitos

Parte-se, neste momento, em busca de fundamentos que auxiliem a construção do direito à identidade sexual perante o ordenamento brasileiro, como a última etapa de concretização do princípio da dignidade humana na tutela da pessoa transexual.

O trajeto iniciado sob o enfoque do valor fundamental da dignidade dividiu-se em dois grandes caminhos. Percorreu, de um lado, os direitos de liberdade e à vida privada, alcançando o desenvolvimento da personalidade, e, de outro, a igualdade, sob o ângulo do reconhecimento jurídico que se revela pela modificação do nome e do sexo no registro civil.

A partir dos elementos reunidos, sempre orientados a contribuir para o combate à violência e à discriminação e a promoção da inclusão da pessoa transexual, chegado o momento de arriscar extrair, entre os direitos da personalidade, um direito do transexual à identidade de gênero, ou sexual, com base na eficácia irradiante dos direitos humanos que assegura a proteção das diversas e infindáveis projeções da pessoa.

Resta, então, justificar a possibilidade dessa expansão.

Como afirma José de Oliveira Ascensão, “as especificações legais não esgotam todo o conteúdo da tutela da personalidade humana". ${ }^{626}$ Assim, embora o autor rejeite o direito geral da personalidade aberto, do sistema germânico, por entendêlo por demasiado extenso e, por isso, difícil de ser trabalhado com segurança, ${ }^{627}$ reconhece a existência de direitos especiais da personalidade na derivação do princípio da dignidade humana. Na lição do autor, a proteção da dignidade impede que sejam admitidas lacunas na proteção da personalidade, justificando adições de novos direitos, "mesmo que não tenham apoio em nenhum específico direito da personalidade demarcado já". ${ }^{628}$ Conclui:

\footnotetext{
${ }^{626}$ ASCENSÃO, José de Oliveira. Direito Civil. Teoria Geral. Vol. I. $2^{\text {a }}$ ed. Coimbra: Coimbra Editora, 2000, p. 86.

${ }_{627}$ Idem, p. 86/87.

${ }^{628}$ Idem, p. 89.
} 
"os direitos da personalidade são atípicos: haverá todos os necessários à defesa da personalidade". 629

No mesmo sentido a conclusão da doutrina brasileira, ao identificar uma matriz constitucional dos direitos da personalidade, como direitos que individualizam e qualificam a pessoa, no desdobramento direto da dignidade ampla e incondicional, constitucionalmente protegida.

Na lição de Maria Celina Bodin de Moraes: "o melhor caminho é reconhecer nos chamados direitos da personalidade expressões da irrestrita proteção jurídica à pessoa humana e, portanto, atribuir-lhes a natureza de princípios de inspiração constitucional". 630

Da concepção de direitos da personalidade como irradiações do princípio da dignidade humana, resulta que o rol de direitos da personalidade positivado pelo legislador brasileiro não é exaustivo, na consideração de que os direitos da personalidade emanam da existência humana, cuja dignidade é preservada pelo ordenamento, com destaque.

Anota Gustavo Tepedino, forte na lição de Pietro Perlingieri, que a tutela da personalidade é dotada do atributo da elasticidade: "No caso da pessoa humana, elasticidade significa a abrangência da tutela, capaz de incidir a proteção do legislador e, em particular, o ditame constitucional de salvaguarda da dignidade humana a todas as situações, previstas ou não, em que a personalidade, entendida como valor máximo do ordenamento, seja o ponto de referência objetivo". ${ }^{631}$

Daí a possibilidade de se reconhecerem outros direitos correspondentes à personalidade, além daqueles expressamente previstos na lei, em observância e na realização do princípio da dignidade da pessoa humana que orienta o ordenamento, promovendo a expansão de direitos com vistas a ampliar a proteção da pessoa.

Nesse sentido, vale conferir o Enunciado n. 247, da IV Jornada de Direito Civil, do Centro de Estudos do Conselho da Justiça Federal, realizada em 2006: “Os direitos da personalidade, regulados de maneira não-exaustiva pelo Código Civil, são expressões da cláusula geral de tutela da pessoa humana, contida no art. $1^{\circ}$, III, da

\footnotetext{
${ }^{629}$ ASCENSÃO, José de Oliveira. Direito Civil. Teoria Geral. Vol. I. $2^{\text {a }}$ ed. Coimbra: Coimbra Editora, 2000, p. 97.

${ }^{630}$ MORAES, Maria Celina Bodin de. Ampliando os Direitos da Personalidade. Na medida da pessoa humana: estudos de direito civil. Rio de Janeiro: Renovar, 2010, p. 128.

${ }^{631}$ TEPEDINO, Gustavo. A Tutela da Personalidade no Ordenamento Civil-constitucional Brasileiro. In Temas de Direito Civil. $4^{\text {a }}$ ed. Rio de Janeiro: Renovar, 2008, p. 55.
} 
Constituição (princípio da dignidade da pessoa humana). Em caso de colisão entre eles, como nenhum pode sobrelevar os demais, deve-se aplicar a técnica da ponderação".

Assim, autorizado concluir pela ausência de obstáculo que impeça a sistematização do direito à identidade sexual do transexual, inserido no contexto de expansão dos direitos humanos. Para tanto, parte-se da contextualização jurídica da identidade, com vistas a estabelecer parâmetros para uma concepão de identidade que, do ponto de vista do sexo, não se limite ao elemento biológico.

\section{2) A identidade no âmbito do direito}

A identidade pressupõe, mas não se esgota no sujeito biológico. Possui uma dimensão ulterior, com base na qual a pessoa pode perceber a si mesma como um eu e ser reconhecida pelos outros como tal, sendo constitutivamente relacional. ${ }^{632}$ Nesse sentido, afirma Francesco D'Agostino que a identidade do sujeito natural é um excedente em relação à sua natureza, pois exige uma integração de experiências que não podem ser fornecidas nem pela biologia nem pela ciência. ${ }^{633}$

De todo modo, considerada a identidade como o fator que nos constitui como sujeitos, estabelece-se a defesa da identidade como norma fundamental, "a partir da qual é constituído todo o sistema normativo, como defesa das expectativas do homem". 634

A identidade, já analisada no Capítulo III, letra A, número 6, sob o prisma da imputabilidade do Ser moral, no plano jurídico pode ser entendida como a exteriorização ou a projeção social da personalidade. ${ }^{635}$

A identidade pessoal, nesses termos, é incluída entre os bens da personalidade, no sentido de satisfazer fins da pessoa e lhe atribuir vantagens, ainda que não se trate de realidade exterior ao sujeito. ${ }^{636}$

Como define Adriano De Cupis: "O indivíduo, como unidade da vida social e jurídica, tem necessidade de afirmar a própria individualidade, distinguindose dos outros indivíduos, e, por consequência, ser conhecido por quem é na realidade. O

${ }^{632}$ D’AGOSTINO, Francesco. A bioética, as biotecnologias e o problema da identidade da pessoa. In Bioética segundo o enfoque da filosofia do direito, cit., p. 190.

633 Idem, p. 193.

${ }^{634}$ Idem, p. 190/191.

${ }^{635}$ LORENZETTI, Ricardo Luis. Fundamentos do Direito Privado, cit., p. 486.

${ }^{636}$ ASCEnSÃO, José de Oliveira. Direito Civil. Teoria Geral, cit., p. 90/91. 
bem que satisfaz esta necessidade é o da identidade, o qual consiste, precisamente, no distinguir-se das outras pessoas nas relações sociais". 637

No processo de distinção com os outros, cada ser atua com autonomia na construção da própria identidade, autodeterminando-se na projeção de "um certo ser psicobiológico específico, na aparência, nos gestos, na fala, nas opiniões e nas atitudes".638

O bem jurídico da identidade pode ser incluído no patrimônio moral da pessoa.

Ensina Cosimo Marco Mazzoni que a expressão integridade moral deve ser entendida em sentido mais amplo, para abranger, além da honra, da reputação e da privacidade, outras propriedades do sujeito, como a liberdade, a identidade pessoal e a igualdade, a fim de cobrir toda a extensão residual que sua antítese, a integridade física, não protege. Afirma que a tutela da identidade decorre da existência de direitos invioláveis que distinguem a pessoa, como o nome e a imagem, esta última referida à esfera de intimidade da pessoa, cuja proteção encontra amparo também sob o direito geral à identidade pessoal. ${ }^{639}$ Em relação ao sexo, após referir que se trata de elemento que igualmente identifica a pessoa, pondera o autor que o conteúdo da identidade em relação ao sexo se estende também à tutela moral, à dignidade e à privacidade da pessoa. ${ }^{640}$

Em atenção à dimensão jurídica, a Corte Italiana vem reconhecendo a autonomia do bem da identidade, sob a denominação de "direito à identidade pessoal", distinto dos demais direitos individualizadores da personalidade como o nome, a imagem, a honra e a privacidade. ${ }^{641}$

Na lição da civilista Maria Celina Bodin de Moraes, "Este novo direito da personalidade consubstanciou-se num 'direito de ser si mesmo' (diritto ad essere se stesso), entendido como o respeito à imagem global da pessoa participante da vida em sociedade, com a sua aquisição de ideias e experiências pessoais, com as suas convicções ideológicas, religiosas, morais e sociais, que a distinguem e ao mesmo tempo a

\footnotetext{
${ }^{637}$ DE CUPIS, Adriano. O direito ao resguardo. In Os direitos da personalidade, cit., p. 165.

${ }^{638}$ SAMPAIO, José Adércio Leite. Direito à Intimidade e à Vida Privada: uma visão jurídica da sexualidade, da família, da comunicação e informações pessoais, da vida e da morte, cit. p. 375.

${ }^{639}$ MAZZONI, Cosimo Marco. Diritti della personalità. In Lineamenti di Diritto Privato. Mario Bessone (org). $5^{\mathrm{a}}$ ed. Torino: G. Giappichelli Editore, 2000, p. 69/70.

${ }^{640}$ Idem, p. 71.

${ }^{641}$ MORAES, Maria Celina Bodin de. Na medida da pessoa humana: estudos de direito civil, cit., p. 137.
} 
qualificam", ${ }^{642} \operatorname{logo}$ ressaltando a intrínseca modificabilidade do direito à identidade pessoal: "De fato, a identidade pessoal pode mudar e freqüentemente muda com a evolução da pessoa". 643

Para Oliveira Ascenção, o direito à identidade pessoal pode ser extraído do direito ao nome, consagrado no art. 26/1, da Constituição da República Portuguesa. $^{644}$

Compõe o direito à identidade, além da possibilidade de autodeterminação de si, nos limites do ordenamento, a faculdade de ser apresentado ao público de uma forma exata, correta e completa. ${ }^{645}$

A identidade contém a intimidade, mas com ela não se confunde, pois inclui não só a dimensão particular, mas também a dimensão pública do ser, como claro está na transcrição de José Adércio Sampaio Leite: “a identidade fala do ser particular, em domínio do individual e do familiar, e do ser público, no sentido de ator público, realizador de atividades públicas". ${ }^{646}$

Assim, pode-se afirmar que o direito à identidade individual possui uma esfera íntima e particular e uma esfera intersubjetiva ou relacional, que envolve o reconhecimento daquilo que se é, ou que se aparenta ser.

No caso do transexual, o tema assume importância central, na consideração de que a identidade consiste em meio de afirmação da individualidade e em elemento distintivo entre as pessoas, o que leva a refletir sobre o direito à identidade de gênero, ou sexual, em oposição à identidade obtida pelo nascimento.

Para tanto, necessário o estabelecimento de uma sensível distinção entre sexo, de um lado, e identidade de gênero ou sexual, de outro.

\section{3) Sexo $x$ identidade de gênero ou sexual}

Desde logo, cumpre consignar que identidade sexual e identidade de gênero serão tratadas como sinônimos, ainda que se afirme a preferência pelo uso da denominação "identidade de gênero", em razão do conteúdo mais amplo. ${ }^{647}$

\footnotetext{
${ }^{642}$ Idem, p. 138.

${ }^{643}$ Idem, p. 139.

${ }^{644}$ ASCENSÃO, José de Oliveira. Direito Civil. Teoria Geral, cit., p. 104.

${ }^{645}$ SAMPAIO, José Adércio Leite. Direito à Intimidade e à Vida Privada: uma visão jurídica da sexualidade, da família, da comunicação e informações pessoais, da vida e da morte, cit., p. 375.

${ }^{646}$ Idem, p. 376.

${ }^{647}$ PERES, Ana Paula Barion. Transexualismo: o direito a uma nova identidade sexual, cit., p, 89.
} 
Nos documentos internacionais a prevalência absoluta é pela expressão "identidade de gênero", mas, nas doutrinas nacional e estrangeira, diversamente, o mesmo tema é tratado sob a denominação de identidade sexual, majoritariamente utilizada pelos autores.

Assim, serão utilizadas ambas as expressões, sempre com o mesmo sentido, emprestando-se também à identidade sexual um significado dinâmico, não limitado ao elemento biológico, mas referido a aspecto construído no curso da vida, no processo de desenvolvimento da personalidade.

Como ressalta Stefano Rodotà, a transexualidade coloca em evidência o problema da classificação dos critérios sociais e jurídicos que definem sexo e identidade sexual. $^{648}$

Sustenta o autor a necessidade de alcançar a concordância entre uma ordem natural, tornada cada vez mais complexa, e o direito, que deve acompanhar tal complexidade, a fim de fornecer normas de referência para a tutela da ação individual e social. $^{649}$

Rodotà aponta para uma diferença temporal entre a obrigação jurídica de definir e anotar o sexo da pessoa no momento do nascimento e o fato de que a estruturação definitiva dos caracteres sexuais demanda um lapso mais longo. A partir daí, vislumbra a possibilidade de contradição entre o tempo jurídico e o tempo de formação da identidade sexual, sustentando a impossibilidade de manutenção da ideia de imutabilidade do estado civil, ou da definitividade da constatação do sexo própria do momento do nascimento.

Prossegue: "o estado da pessoa, que consta em seu registro civil, é uma descrição do papel social referente a um dado biológico presumidamente imutável. Mas sabemos bem e já foi dito que esta presunção, esta ficção jurídica, não pode mais ser considerada na atualidade com a mesma certeza que no passado" (tradução livre). ${ }^{650}$

\footnotetext{
${ }^{648}$ RODOTÀ, Stefano. Présentation Générale des problèmes liés au transsexualisme. In Transsexualisme, médicine e droit. Actes XXIII Colloque de droit européen. Vrije Universiteit Amsterdam (Pays-Bas) 14-16 avril, 1993, p. 17. Disponível em: <books.google.com.br/books?id=5_ludHUsNAC\&printsec=frontcovepage \& $\mathrm{q}=$ Transsexualisme $\% 2 \mathrm{C} \% 20$ médicine\%20et\%20droit\&f=true $>, \quad$ p. $\quad 17-24$ último acesso em 16/12/2011.

${ }^{649}$ Idem, p. 20.

650 "l'état des personnes qui résulte des registres de l'état civil est une discription du rôle social liée à une donnée biologique présumée immuable. Mais vous savez bien et on l'a déjà dit que cette présomption, cette fiction juridique, ne peuvent pas être considérées aujourd'hui avec la même certitude que dans lê passe", Idem, p.21.
} 
No mesmo sentido, Sessarego, ao tratar da mudança de sexo, afirma que o gênero resulta da integração de vários elementos, como o sexo morfológico, o cromossômico, o gonádico, o genético, o sociológico, o social e o jurídico. ${ }^{651}$ Por isso, o gênero não pode ser considerado um elemento imutável da pessoa, adquirido juridicamente e para sempre com a inscrição do estado civil no registro, resultando do desenvolvimento da personalidade. ${ }^{652}$

Nesses moldes, autorizado afirmar que a definição de identidade sexual não se limita aos fatores estáticos e imutáveis da pessoa, como o genético, somático e cromossômico, mas se reporta aos elementos dinâmicos da identidade, psicológicos, sociais, culturais e educacionais, que levam o indivíduo a sentir-se e a estar convencido de pertencer a determinado sexo, íntima e socialmente. ${ }^{653}$

Trata-se de perspectiva que "concebe o sexo não como um atributo instantaneamente adquirido na concepção, segundo a visão biomédica, mas, a partir do reconhecimento da imprescindibilidade da esfera psíquica, como um aspecto que se vai aos poucos formando, em processo que ocorre até o início da vida adulta". 654

Tais lições deixam clara a distinção doutrinária entre o sexo biológico (estático e imutável) e a identidade sexual (dinâmica e, por isso, mutável), tornada relevante na transexualidade. E, exatamente porque a doutrina admite uma diferença entre sexo e identidade de gênero ou sexual, pode-se pensar na identidade civil em contraposição à biologia do sexo.

Stefano Rodotà, após reconhecer a existência de uma tensão entre sexo e gênero na atual concepção de identidade sexual, afirma a importância de associar à concepção tradicional de sexo a consideração de gênero, entendido como papel social desempenhado pela pessoa ou sexo psicossocial. ${ }^{655}$

\footnotetext{
${ }^{651}$ SESSAREGO, Carlos Fernandez. El cambio de sexo y su incidencia en las relaciones familiares, cit., p. 10.

${ }^{652}$ Idem, p. 11.

${ }^{653}$ PERONA, Javier López-Galiacho. La problemática jurídica de la transexualidad. Madri: McGrow-Hill, 1998, p. 110.

${ }^{654}$ MORAES, Maria Celina Bodin de. Na medida da pessoa humana: estudos de direito civil. Rio de Janeiro: Renovar, 2010, p. 132.

${ }^{655}$ Présentation Générale des problèmes liés au transsexualisme. In Transsexualisme, médicine e droit. Actes XXIII Colloque de droit européen. Vrije Universiteit Amsterdam (Pays-Bas) 14-16 avril, 1993, p. 21. Disponível em: <books.google.com.br/books?id=5_ludHUsNAC\&printsec $=$ frontcovepage $\& q=$ Transsexualisme $\% 2 C \% 20$ médicine $\% 20$ et $\% 20$ droit\&f=true $>, \quad$ p. $\quad 17-24$ último acesso em 16/12/2011.
} 
Sinaliza para uma classificação jurídica do estado civil baseada numa concepção de identidade que resulte da combinação de sexo e gênero, pela interação do elemento biológico natural com o desenvolvimento da pessoa em seu meio social.

Em suas palavras, a identidade seria "um problema não simplesmente do registro de certos dados naturais, mas o resultado de um processo de autoidentificação no próprio interesse, do qual a mudança de aspectos do estado civil é o marco final e a sanção formal" (tradução livre). ${ }^{656}$

Assim, compreendida a identidade não como valor projetável, anterior ao indivíduo, mas, sim, como fato consistente na existência concreta de alguém, baseado na sua realidade efetiva, ${ }^{657}$ autoriza-se uma definição da identidade sexual fora do marco estritamente biológico, prevalecendo nessa identificação, o aspecto aparente e relacional da pessoa, que se revela no curso do desenvolvimento da personalidade e não se prende às características adquiridas no momento do nascimento.

Esse o contexto em que se insere o direito à identidade de gênero ou sexual, baseado na distinição conceitual entre sexo, como elemento biológico e imutável, e gênero, resultante da interação do ser natural com seu meio social.

\section{4) $O$ direito à identidade de gênero ou sexual na doutrina}

No âmbito do direito interno dos países da comunidade europeia, a partir dos anos setenta, verificou-se a tendência de reconhecimento do direito à identidade sexual do transexual. ${ }^{658}$

Javier López-Galiacho Perona identifica, na doutrina e jurisprudência Europeia, vários fundamentos para a construção dogmática do direito à identidade sexual. Após afirmar que se trata de espécie do gênero direito à identidade, e desdobramento da dignidade da pessoa humana, relaciona-o à tutela da saúde, da intimidade, da integridade física e moral e aos direitos correlatos da personalidade, como o direito ao livre desenvolvimento da personalidade. $\mathrm{O}$ autor atribui à doutrina italiana e à jurisprudência alemã a consideração do direito à identidade sexual como expressão do

\footnotetext{
656 “C'est un problème non simplement d'enregistrement de certaines données naturelles, mais le résultat d'un processus d'auto-identification par les intéressés même, dont le changement des actes de l'état civil est la démarche finale et la sanction formelle”, Idem, p. 23.

657 D'AGOSTINO, Francesco. A bioética, as biotecnologias e o problema da identidade da pessoa. In Bioética segundo o enfoque da filosofia do direito, cit., p. 191.

${ }^{658}$ PERONA, Javier López-Galiacho. La problemática jurídica de la transexualidad, cit., p. 108.
} 
direito ao desenvolvimento da personalidade e da dignidade humana, reconhecendo o direito do transexual operado a ter seu novo sexo reconhecido no registro civil. ${ }^{659}$

Entende Javier Perona que o direito à identidade constitui novo direito da personalidade, afirmando e refletindo a dignidade humana e tutelando as prerrogativas e garantias de gozo das faculdades do corpo e do espírito pela pessoa, ${ }^{660}$ no exercício de sua liberdade. Isso porque, tuteladas a vida e a liberdade, assegura-se a todo indivíduo a possibilidade de se realizar de acordo com o gênero a que se sente pertencer, a partir da perspectiva não biológica, mas existencial de sexo. ${ }^{661}$

Em relação à saúde, afirma que o conceito amplo da Organização Mundial de Saúde, inclusivo do bem-estar geral, psíquico, mental e social, igualmente corrobora o direito à identidade sexual, permitindo ao sujeito, por meio da redesignação de sexo, alcançar uma estabilidade e equilíbrio dos quais carecia, ${ }^{662}$ o que significa proteção também à sua integridade psicofísica. ${ }^{663}$

Aponta também a proteção da intimidade e da própria imagem, além da tutela contra discriminação, como outros fundamentos que autorizam o reconhecimento da autonomia do direito à identidade sexual entre os direitos da personalidade. Isso porque, negado o direito, estar-se-ia submetendo a pessoa ao constrangimento de exibir documentos contraditórios com sua aparência, em violação de sua intimidade. ${ }^{664}$

Refere Fernández Sessarego à identidade sexual como um dos mais importantes e complexos aspectos da identidade pessoal, conexa com o desenvolvimento da personalidade, a tutela da saúde, a proteção da integridade psicossomática e com os atos de disposição do próprio corpo. Fixa seu ponto de partida na definição de como se constitui e determina o sexo de uma pessoa. ${ }^{665}$

Cosimo Marco Mazzoni, especificamente ao comentar sobre a regulação da transexualidade pela Lei Italiana $n^{\circ} 164 / 1982$, que autoriza a mudança de sexo no registro após a cirurgia de redesignação, reconhece a existência do direito à

\footnotetext{
${ }^{659}$ Idem, p. 111/112.

${ }^{660}$ Idem, p. 115.

${ }^{661}$ Idem, p. 116.

${ }^{662}$ Idem, p. 120/121.

${ }^{663}$ Idem, p. 123.

${ }^{664}$ Idem, p. 124.

${ }^{665}$ El cambio de sexo y su incidencia en las relaciones familiares. In Revista de Direito Civil, Imobiliário, Agrário e Empresarial. Ano 15. vol 56, Abril-junho, 1991, p. 08.
} 
identidade sexual, ${ }^{666}$ assegurando à pessoa a possibilidade de ser reconhecida pelo seu sexo de identificação no registro, ainda que diverso do sexo biológico.

Perante o ordenamento espanhol, a possibilidade de alteração do nome e sexo no registro, nos termos da Lei $n^{\circ} 3 / 2007$, vem sendo interpretada como o reconhecimento implícito do direito à identidade sexual, recentemente denominado direito à identidade de gênero, considerado uma expressão do livre desenvolvimento da personalidade e de sua dignidade, previsto no art. 10.1, da Constituição Espanhola. ${ }^{667}$ Lembra Yolanda Moreno que, mesmo antes da edição da Lei $n^{\circ} 3 / 2007$, o Tribunal Superior Espanhol já havia autorizado a mudança nos assentos de registro, identificando "um direito de sustentar a identidade sexual como expressão da identidade pessoal, que é um bem da personalidade", 668

Entre nós, Maria Helena Diniz reconhece a identidade sexual como um princípio constitucional referido ao direito da personalidade. ${ }^{669}$

Elimar Szaniawski considera a identidade sexual como um dos aspectos da identidade pessoal, vislumbrando um interesse juridicamente relevante em gozar a própria identidade sexual. Segundo o autor, o interesse da pessoa consiste "no reconhecimento, sob todos os aspectos da vida social, privada e pública, como sendo a mesma, pertencente ao próprio sexo". ${ }^{670}$

José Adércio Leite Sampaio relaciona a identidade sexual à liberdade individual de comportamento, aparência e biotipia. Remete à lição de De Cupis, para quem a identidade sexual corresponde ao “"poder' de aparecer externamente igual a si mesmo em relação à realidade do próprio sexo, masculino ou feminino, vale dizer, o direito ao exato reconhecimento do próprio sexo real, antes de tudo na documentação constante dos registros do estado civil". ${ }^{671}$

A identidade sexual, na acepção de Tereza Rodrigues Vieira, consiste no "sentimento que a pessoa tem de pertencer a um sexo, independentemente da determinação de sua genitália", em busca de harmonia entre seu corpo e seu sexo psicológico. ${ }^{672}$

\footnotetext{
${ }_{666}^{6}$ MAZZONI, Cosimo Marco. Diritti della personalità. In Lineamenti di Diritto Privato, cit., p. 71.

${ }^{667}$ MORENO, Yolanda B. Bustos. La transexualidad. Madri: Editorial Dykinson, 2008, p. 111/112.

668 "un derecho de sostener la identidad sexual como expresión de la identidad personal, que es un bien de la personalidad", in MORENO, Yolanda B. Bustos. La transexualidad, cit., p. 114.

${ }^{669} \mathrm{O}$ estado atual do biodireito. $4^{\mathrm{a}}$ ed. São Paulo: Saraiva, 2007, p. 252.

${ }^{670}$ Limites e possibilidades do direito de redesignação do estado sexual, cit., p. 34 e p. 35.

${ }^{671}$ Direito à intimidade e à vida privada, cit., p. 314.

${ }^{672}$ A bioética e o direito à adequação de sexo do transexual. In Bioética e sexualidade. VIEIRA, Tereza Rodrigues (coord). São Paulo: Editora Jurídica Brasileira, 2004, p. 111.
} 
Por sua vez, admite Roxana Cardoso Brasileiro Borges, após apontar autores que situam a mudança de sexo decorrente da transexualidade no âmbito do direito ao corpo, do direito à integridade psíquica ou psicofísica, a possibilidade de tratar a transexualidade sob o aspecto do direito à identidade. ${ }^{673}$

A identidade sexual, nessa esteira, corresponde ao reconhecimento jurídico de projeção da personalidade da pessoa que, no curso da vida, percebe-se como alguém do sexo oposto ao biológico e, com essa firme convicção, decide passar a viver como pertencente ao sexo que sente ser. Em consequência, a identidade original, adquirida pelo nascimento, deixa de lhe fazer sentido, tornando necessária uma nova identidade, que corresponda ao modo pelo qual a pessoa passou a se relacionar e ser conhecida. Essa nova identidade, baseada no gênero e no reconhecimento da importância da intersubjetividade para as relações humanas, é a identidade sexual.

Pelo exposto, acredita-se possível admitir a existência autônoma do direito à identidade de gênero entre os direitos da personalidade, o que se afigura especialmente relevante para a tutela dos direitos humanos da pessoa transexual, evitando que permaneça vítima de exclusão, pela garantia dos direitos à liberdade e à igualdade.

Pode-se afirmar, retomando as lições de Axel Honneth, que o reconhecimento jurídico da identidade sexual, ao permitir a identificação do indivíduo por aquilo que ele se tornou, no percurso do desenvolvimento de sua personalidade, equipara-o à pessoa merecedora dos mesmos direitos gozados pelos demais membros da comunidade. A partir do respeito à liberdade individual, destarte, o reconhecimento jurídico da identidade de gênero alça o indivíduo ao patamar de sujeito moralmente imputável, reestabelecendo a igualdade entre os parceiros de interação.

Nessa medida, a identificação civil da pessoa por sua identidade de gênero ou sexual, de acordo com a percepção íntima de si própria e coerentemente com a aparência física, contribuirá para proteger os transexuais contra a violência e discriminação a que estão atualmente expostos, quer porque estarão protegidos de constrangimento público, quer em razão da força simbólica do direito.

${ }^{673}$ Direitos da personalidade e autonomia privada. $2^{\text {a }}$ ed. São Paulo: Saraiva, 2007, p. 188. 


\section{5) $O$ direito à identidade de gênero na jurisprudência da}

\section{Corte Europeia de Direitos Humanos}

$\mathrm{Na}$ jurisprudência da Corte Europeia de Direitos Humanos verificou-se uma evolução, com base no art. $8^{\circ}$, da Convenção Europeia de Direitos Humanos, sob o enfoque do respeito à autoidentificação do sujeito, cuja intimidade é tutelada pelo direito à vida privada.

$\mathrm{O}$ direito à intimidade foi o principal argumento na primeira demanda sobre transexualidade efetivamente apreciada pela Corte, contra a Bélgica (7654/1976), no pressuposto de que a discordância entre a aparência e a documentação oficial obrigava a pessoa a revelar a terceiros dados estritamente pessoais. ${ }^{674}$ No entender da Comissão, seria incompatível com a obrigação de respeitar a vida privada impor à pessoa, que por recomendação médica adquiriu características e aparência do sexo oposto, apresentar documento de identidade contraditório com sua aparência. Para a Comissão, a conduta do Estado violara aspecto relevante da personalidade, deixando de reconhecer sua identidade sexual, resultante da morfologia modificada, do psiquismo e do papel social do demandante. ${ }^{675}$

Em outro precedente, contra o Reino Unido (95326/1981), o demandante alegou que a manutenção do sexo natural no registro significava uma intromissão arbitrária na sua intimidade, ao permitir que terceiros obtivessem uma certidão do sexo natural. A Comissão acolheu o argumento, com base na proteção da personalidade pelo reconhecimento do sexo, evitando que o demandante fosse tratado como um ser ambíguo.

Em que pesem os citados pareceres favoráveis da Comissão, a Corte Europeia apenas reconheceu o direito à modificação do sexo no registro em 25 de março de 1992, com base no art. $8^{\circ}$ da Convenção, no caso Lyne Botella contra a França ${ }^{676}$ Todavia, posteriormente a Corte retornou ao entendimento anterior e negou novamente o direito à identidade de gênero, até 2002, quando o princípio da imutabilidade do sexo acabou por ser definitivamente refutado pelo Tribunal Europeu de Direitos Humanos, no julgamento do caso Christine Goodwin contra Reino Unido. ${ }^{677}$

\footnotetext{
${ }^{674}$ PERONA, Javier López-Galiacho. La problemática jurídica de la transexualidad, cit., p. 128.

${ }^{675}$ Idem, p. 129.

676 ALMEIDA, Suzana. O respeito pela vida (privada e) familiar na jurisprudência do Tribunal Europeu dos Direitos do Homem: a tutela das novas formas de família, cit., p. 231.

${ }^{677}$ Idem, p. 226.
} 
Dada a importância desse julgamento, representativo da mudança de orientação da Corte, cabe tecer algumas considerações, no pressuposto de que a argumentação jurídica desenvolvida por uma Corte Internacional pode auxiliar na construção da tutela jurídica interna dos transexuais, em consequência da internacionalização dos direitos humanos. Tal internacionalização, resultante do esforço de reconstruir os direitos humanos como paradigma e referencial ético no pós Segunda Guerra, ${ }^{678}$ permite que se busquem no Direito Internacional dos Direitos Humanos fundamentos que auxiliem na interpretação dos direitos constitucionalmente garantidos. ${ }^{679}$

\section{5.a) Análise do caso Christine Goodwin contra o Reino}

Unido

O caso Christine Goodwin contra o Reino Unido foi apresentado à Comissão Europeia em 05/06/1995 e acabou admitido em 01/12/1997, sendo enviado à Corte em 01/11/1998. Em 11/09/2001, uma Câmara da Terceira Seção enviou o caso ao Tribunal Pleno (Grand Chamber), sendo o caso julgado pela Corte Europeia de Direitos Humanos em 11/07/2002, sob o número de reclamação 28957/95. ${ }^{680}$

Dos comentários de Fabiane Verçosa, publicados no volume $n^{\circ}$ 5, dos Arquivos de Direitos Humanos, extraem-se outras informações: A recorrente nasceu e foi registrada como pertencente ao sexo masculino, chegando a casar com uma mulher e ter quatro filhos. Contudo, sentia-se inadequada na posição de homem e passou a viver como mulher definitivamente a partir de 1985, submetendo-se à cirurgia de mudança de sexo pelo Serviço Nacional de Saúde, em 1990. Por ser transexual, foi demitida e, receosa de apresentar seu número de seguridade nacional ao novo empregador, solicitou ao Departamento de Seguridade Nacional um novo número, o que lhe foi negado. ${ }^{681}$

Afirma a demandante que encontrou dificuldades com a contribuição de seguro previdenciário, porque legalmente continuava homem e teria de pagar a contribuição até os 65 anos, ao invés de 60 anos, completados em 1997. Informa que teria de prosseguir pagando a contribuição pessoalmente, para evitar questionamentos e constrangimentos perante seu empregador, o que ocorreria se fosse obrigada a revelar a

\footnotetext{
${ }^{678}$ PIOVESAN, Flavia. O direito internacional dos direitos humanos e a redefinição da cidadania no Brasil. In Temas de Direitos Humanos, p. 32.

${ }_{679}^{679}$ LAFE, Celso. A internacionalização dos direitos humanos. Barueri, SP: Manole, 2005, p. 42.

680 Resumo do julgamento disponível em: <cmiskp.echr.coe.int/tkp197/view.asp?item=1\&portal=hbkm\&action0united\%20\%7C\%20kingdom\&sessioni $\mathrm{d}=81797137 \&$ skin=hudoc-em $>$, acesso em novembro de 2011 .

${ }^{681}$ Arquivos de Direitos Humanos, vol 5, Rio de Janeiro: Renovar, p. 314.
} 
cirurgia. Além disso, o fato de manter o mesmo número de seguridade nacional anterior à cirurgia significava que o empregador poderia descobrir que ela trabalhava sob outro nome e gênero, resultando em constrangimento e humilhação. ${ }^{682}$

Em sua petição, a autora reclama da falta de reconhecimento legal do gênero pós-operatório, correspondente ao sexo feminino, e sobre o status legal do transexual no Reino Unido, especialmente em relação a emprego, seguro social, pensão e incapacidade para casar. Sustenta sua pretensão no artigo 8 (direito à vida privada); no artigo 12 (direito ao casamento); no artigo 13 (direito a um recurso efetivo); e no artigo 14 (direito de igualdade), da Convenção Europeia de Direitos Humanos. ${ }^{683}$

A Corte analisou a alegação da violação de cada artigo, separadamente, dando maior ênfase à análise do art. $8^{\circ}$. A íntegra dos argumentos foi analisada a partir da publicação virtual do julgamento, obtida no endereço eletrônico <cmiskp.echr.coe.int/tkp197/view.asp?item=1\&portal=hbkm\&action0united $\% 20 \% 7 \mathrm{C} \% 20$ kingdom\&sessionid=81797137\&skin=hudoc-em>, e traduzida livremente

Em relação à alegação de violação ao artigo $8^{\circ}$ (direito ao respeito pela vida privada e familiar), a Corte entendeu contraditório que, não obstante a autora tivesse obtido a mudança de sexo, de masculino para feminino, por cirurgia realizada pelo sistema público de saúde inglês, ela continuasse juridicamente pertencente ao sexo masculino, com consequências legais em relação a pensões e idade para aposentadoria, entre outras. No entender da Corte, tal situação resultou em um sério conflito entre a realidade social e a lei, colocando os transexuais em posição anômala, que os submete a sentimentos de vulnerabilidade, humilhação e ansiedade (§ 77).

Para a Corte, embora não existam conclusões definitivas sobre a causa da transexualidade, relevou mais o fato de haver um amplo reconhecimento internacional sobre as possibilidades, adequação e tipos de tratamento, concluindo que a impossibilidade de o transexual adquirir todas as características biológicas do sexo oposto não tem importância definitiva no enquadramento da questão (§ 81).

A Corte mencionou uma clara tendência internacional da aceitação social do transexual e do reconhecimento legal da nova identidade sexual, póscirúrgica, citando, nesse sentido, as legislações holandesa, italiana, neozelandesa e turca.

\footnotetext{
682 Resumo do julgamento disponível em: <cmiskp.echr.coe.int/tkp197/view.asp?item=1\&portal=hbkm\&action0united\%20\%7C\%20kingdom\&sessioni $\mathrm{d}=81797137 \&$ skin=hudoc-em $>$, acesso em novembro de 2011 .

683 ALMEIDA, Suzana. O respeito pela vida (privada e) familiar na jurisprudência do Tribunal Europeu dos Direitos do Homem, cit., p. 236.
} 
Os juízes entenderam que a tutela da vida privada da autora impunha o reconhecimento jurídico da nova realidade, no plano dos direitos, a fim de manter o compasso entre as áreas de saúde e as áreas das ciências sociais, ou entre o fato e o Direito, considerando que a cirurgia havia sido realizada pelo sistema de saúde público inglês, de acordo com as normas próprias daquela instância .

Para a Corte, importou o fato de não ter sido apontado elemento indicativo de que terceiros sofreriam prejuízo material decorrente da alteração do registro civil quanto ao gênero, tendo sido consignado que o Governo estava constantemente discutindo propostas de reforma dos sistemas de registro para permitir retificações do estado civil. A Corte ressaltou que o Governo Inglês admitia, outrossim, exceções à imutabilidade do registro, no caso de adoção, por exemplo, entendendo que a alteração pretendida pelo transexual não implicava ameaça ao sistema de registros como um todo. ${ }^{684}$

A Corte enfatizou que a essência da Convenção era o respeito à dignidade humana e à liberdade. Sob o artigo $8^{\circ} \mathrm{em}$ particular, no qual a noção de autonomia pessoal é um princípio que orienta a interpretação das garantias à vida privada, a proteção é dada à esfera pessoal de cada indivíduo, incluindo o direito de definir detalhes da própria identidade como seres humanos. De acordo com as razões do julgamento, no século XXI, o direito do transexual ao desenvolvimento pessoal e à segurança física e moral, na amplitude gozada pelos outros em sociedade, não pode ser encarado como uma questão controvertida que requereria tempo para ser equacionada, à luz dos valores envolvidos ( $\$ 90)$.

A Corte entendeu que as repercussões inevitáveis no registro civil, filiação, seguridade social, direito de família e direito das sucessões não são insuperáveis, amparada em propostas fornecidas pelo Grupo de Trabalho Interdepartamental com pessoas transexuais (\$91).

Entendeu não demonstrado que a mudança de estado do transexual implicaria concreta violação ao interesse público, consignando ser razoável esperar a tolerância da sociedade para com eventuais inconvenientes, a fim de permitir aos indivíduos viver com dignidade e respeito, de acordo com a identidade sexual por eles escolhida com grande custo pessoal, concluindo pela violação ao direito à vida privada protegido pelo artigo 8 , da Convenção ( $(91)$.

${ }^{684}$ VERÇOSA, Fabiane. Arquivos de Direitos Humanos, vol 5, p. 316. 
A Corte concluiu que a ausência do reconhecimento legal ao transexual pós-operado violava sua dignidade, liberdade e autonomia e refutou o argumento da Inglaterra de que a proteção do transexual causaria prejuízos a terceiros, expressamente consignando a razoabilidade da expectativa de tolerância da sociedade para conviver com o diferente $(\S 91)$.

Sob o enfoque do art $8^{\circ}$, destarte, a Corte entendeu que os fatores biológicos não são decisivos para negar o reconhecimento da mudança de gênero ao transexual pós-operado. Ponderou que há outros fatores importantes, como o reconhecimento da disforia de gênero no âmbito interno do país signatário; o oferecimento de tratamento, inclusive cirúrgico, para aproximar o indivíduo o máximo possível ao gênero a que ele sente pertencer; e a assunção pelo transexual, do novo gênero, no meio social.

Em relação à alegada violação ao Artigo 12 (direito ao casamento), a Corte foi além das questões relativas à vida privada, discutidas no âmbito do art. $8^{\circ}$, e entendeu que a impossibilidade de alteração do registro de nascimento do pósoperado implica violação ao direito do indivíduo de casar. Isso porque, embora remanesça a possibilidade de casamento com o sexo oposto, como ponderado pelo país processado, essa desconsidera o interesse particular do transexual que vive como mulher de casar com alguém que seja do sexo masculino, sendo que essa impossibilidade caracteriza uma violação à essência do direito de casar (§101).

No entender da Corte, o fato de, na comparação, menos países autorizarem o casamento de transexuais do que permitirem a alteração do gênero no registro, não autoriza deixar a questão para ser decidida de acordo com a margem de apreciação do Estado. Isso importaria em permitir ao Estado contratante a colocação de barreiras ao exercício do direito de casar, tendo a Corte consignado que a margem de apreciação não pode ter essa extensão ( $§ 103)$.

Por outro lado, a Corte reconheceu que o Estado contratante pode determinar internamente as condições necessárias para a retificação de gênero e as formalidades exigíveis para o casamento, como o fornecimento da informação ao futuro cônjuge, mas não pode impedir ao transexual o direito de casar, sob pena de violação ao art. 12, da Convenção Europeia ( $\$ 103)$.

No tocante à alegação de violação ao Artigo 13 (direito a um recurso efetivo), segundo a Corte, a possibilidade de a demandante formular reclamações 
perante os Tribunais internos significa que não ocorreu violação ao art. 13, da Convenção $(\S 113)$.

Em relação ao Artigo 14 (proibição de discriminação), a Corte entendeu que a impossibilidade legal do reconhecimento da mudança de gênero ao transexual pós-operado, perante o ordenamento jurídico, significa uma violação ao art. 8, inexistindo uma violação autônoma do art. 14, que trata da proibição da discriminação. Por isso, a Corte não apreciou em separado a alegação de violação ao art. 14, entendendo-a absorvida pelo art. $8(\S 108)$.

Nesse ponto, a interpretação poderia ser criticada.

Cançado Trindade, embora reconheça nas decisões das Cortes Internacionais o uso de método interpretativo favorável ao caráter objetivo e autônomo das obrigações contraídas nos Tratados de Direitos Humanos, estabelecendo limites ao voluntarismo estatal e resultando em nova visão, resumida na ideia de que o Estado existe para o ser humano, e não o contrário, obtempera: "Mas ainda resta um longo caminho a percorrer. No plano substantivo, por exemplo, há que devotar maior atenção ao considerável potencial de aplicação do princípio da não-discriminação no presente domínio de proteção". 685

No caso em foco, a Corte não aproveitou o julgamento para o aprofundamento do princípio da não-discriminação, entendendo a discriminação absorvida pela proteção da vida privada. Desse modo, perdeu a oportunidade de dar conteúdo ao princípio da não-discriminação em relação à mudança de gênero.

Mesmo assim, tal decisão, de 2002, representou uma guinada no entendimento da Corte sobre a proteção da vida privada do transexual, no reconhecimento do direito à identidade sexual, o que se confirmou nas decisões posteriores do Tribunal Europeu, exemplificadas por Suzana Almeida: Acórdão Van Kück c. Alemanha, de 12 de junho de 2003, e Acórdão Grant c. Reino Unido, de 23 de maio de $2006 .{ }^{686}$

Assim, pelo exposto no item 5 e neste item 6, percebem-se, na doutrina e na jurisprudência, elementos suficientes para reconhecer o direito à identidade sexual entre os direitos da personalidade. Seu conteúdo inclui a proteção da pessoa e da personalidade, naquilo que expressa seu sentimento de ser e sua aparência de pertencer ao

${ }^{685}$ Tratado de Direito Internacional dos Direitos Humanos, vol. II. Porto Alegre: Sergio Fabris Editor, 1999, p. 190.

${ }^{686} \mathrm{O}$ respeito pela vida (privada e) familiar na jurisprudência do Tribunal Europeu dos Direitos do Homem, cit., p. 240/242. 
gênero masculino ou feminino, a partir de uma perspectiva dinâmica de sexo e relacional de identidade.

Declarado o direito, sua concretização dar-se-á pela anotação do sexo de identificação no assento de nascimento da pessoa, no efetivo reconhecimento da identidade de gênero.

\section{6) Uma proposta de reconhecimento do direito à identidade} de gênero ou sexual independentemente da intervenção cirúrgica para a redesignação do sexo

Como visto no item II.9, as pesquisas de campo realizadas por psicólogos e cientistas sociais comprometeram a conclusão quanto ao caráter monolítico da transexualidade.

Uma das mais importantes constatações refere-se ao desejo pela operação para mudança de sexo, que se mostrou ausente em alguns casos, desmistificando a ideia de que o conflito identitário estaria sempre e necessariamente acompanhado da premência em realizar a cirurgia.

Na experiência de Catherine Millot, os homens transexuais, em sua maioria, contentam-se em extirpar seus órgãos femininos e em tomar hormônios masculinos, assumindo o papel do gênero oposto independentemente de cirurgia. Afirma a autora francesa: "Enquanto esperam, obtém, sem pênis, a mudança do estado civil e, legalmente providas de uma identidade masculina, casam-se com mulheres e tornam-se pais de crianças inseminadas artificialmente, sem que ninguém duvide de sua identidade original". 687

Semelhantes os resultados encontrados por Berenice Alves de Melo Bento, ao se aproximar de transexuais que não acreditam na cirurgia como solução para a questão de identidade de gênero que trazem. Nas palavras da autora, eles "Reivindicam não o direito à cirurgia de transgenitalização, mas à identidade legal do gênero identificado mediante a mudança do nome próprio e do sexo nos documentos". 688

O depoimento de Camille Cabral, franco-brasileira, primeira transexual eleita na história da França, em 2001, pelo Partido Verde Francês, fundadora do PASST (1993)- Prévention Action Santé Travail pour les transgenrs - Prevenção, Ação,

${ }^{687}$ MILLOT, Catherine. Extrasexo: ensaio sobre o transexualismo, cit., p. 92.

${ }^{688}$ BENTO, Berenice Alves de Melo. Da transexualidade oficial às transexualidades. In Piscitelli, Adriana; Gregori, Maria Filomena; Carrara, Sergio (orgs). Sexualidade e saberes: convenções e fronteiras, cit., p. 163. 
Saúde e Trabalho para os transgêneros - ilustra a questão: “A identidade de gênero não está ligada à mudança de sexo. Nosso fenômeno não é genital, mas de sensibilidade, de atitude. Não existe nenhum parâmetro que exija que nós tenhamos de fazer operações genitais para podermos ter nossos direitos reconhecidos". ${ }^{689}$

Essa realidade revela-se nas exigências do grupo transgênero da ILGA - International Lesbian, Gay Bisexual, Trans and Intersex Association, reivindicando internacionalmente o direito à identidade sexual independentemente da mudança de sexo, como se depreende pela leitura da primeira e quarta exigências centrais: "Igualdade total e direitos humanos, particularmente o direito à integridade física, abolindo por exemplo os requisitos ilegais da infertilidade irreversível ou da cirurgia da reatribuição de sexo forçada", e "liberdade de ser plenamente reconhecido pela lei no que diz respeito ao estado civil na sua própria identidade de gênero, e em toda documentação estatal e pessoal, sem prejuízo para o tratamento hormonal ou operações de reatribuição de sexo e sem requerimento legal de procedimentos de esterilização ou cirurgia irreversível". 690

Entre as causas para a reivindicação do reconhecimento da identidade de gênero sem cirurgia, aponta Yolanda Moreno o alto custo da operação, os riscos envolvendo a saúde e as respeitáveis razões pessoais de cada um, que não podem ser desconsideradas. ${ }^{691}$

Nesse panorama, vislumbra-se o deslocamento da luta por reconhecimento: do direito ao corpo, que se pleiteava em relação à possibilidade de mudança, para o direito à identidade.

A questão coloca-se, desse modo, especificamente em relação aos transexuais que optam por outras formas de tratamento, promovendo mudanças em seus caracteres sexuais secundários e a transformação de sua aparência física por meio do uso de hormônios, maquiagem, silicones, e outras técnicas menos invasivas, passando a viver de modo estável como pertencentes ao gênero oposto, sem se submeter à cirurgia para mudança de sexo.

Neste ponto, vale lembrar que o desejo pela operação, nos moldes desenvolvidos no capítulo II.8, não é essencial para a caracterização da transexualidade, admitindo-se outros tratamentos, como expresso na Portaria $\mathrm{n}^{\mathrm{o}}$ 1.707/2008, do Ministério da Saúde, que instituiu o processo transexualizador no âmbito

\footnotetext{
${ }^{689}$ Disponível em: <http://pt.wikipedia.org/wiki/Camille_Cabral>, acesso em 29/08/2011.

${ }^{690}$ Disponível em: < www.opusgay.org/index.php/projetos/transexualidade.html?start=60 $>$, acesso em novembro de 2011.

${ }^{691}$ MORENO, Yolanda B. Bustos. La transexualidad, cit., p. 155/156.
} 
do SUS e determinou a "integralidade da atenção, não restringindo nem centralizando a meta terapêutica no procedimento cirúrgico de transgenitalização" (art. $2^{\circ}$, I). ${ }^{692}$

A realidade que se abre diante de tais considerações inspira a reflexão sobre a possibilidade de se reconhecer a identidade sexual independentemente da mudança física do sexo, no pressuposto de que a melhor proteção jurídica, sob a ótica dos direitos humanos, é aquela que realiza a igualdade, acolhendo a diferença.

Na preciosa lição de Flávia Piovesan: "A ética emancipatória dos direitos humanos demanda transformação social, a fim de que cada pessoa possa exercer, em sua plenitude, suas potencialidades, sem violência e discriminação. É a ética que vê no outro um ser merecedor de igual consideração e profundo respeito, dotado do direito de desenvolver as potencialidades humanas, de forma livre, autônoma e plena". ${ }^{63}$

Daí a abertura para pensar o reconhecimento da identidade de gênero em respeito à singularidade da pessoa transexual que se revela e se diferencia, ao não desejar realizar a operação para mudança de sexo.

Argumentos favoráveis a admitir o direito à identidade sexual do transexual não operado podem ser alinhavados, com vistas a evitar o aprofundamento de seu constrangimento e de sua dor, pela imposição de uma cirurgia que seria sentida como uma violência física a quem já experimenta um grave desconforto psíquico.

Em tal circunstância, exigir a intervenção cirúrgica como condição para o reconhecimento da identidade de gênero pode acabar implicando uma violação à autonomia e ao direito à integridade, na hipótese em que a pessoa se submeta à operação coagida pela necessidade de obter a adequação entre sua aparência e sua qualificação jurídica, sendo forçada a concordar com a mudança em seu corpo para ter reconhecido seu gênero de identificação.

Como explicou um transexual entrevistado pela psicóloga Catherine Millot, a infelicidade do transexual consiste em não existir um terceiro sexo, diante do que a cirurgia acaba sendo sentida como meio para se livrar dos insultos e sofrimentos. ${ }^{694}$

Nessa hipótese, a cirurgia, ao invés de concretizar o exercício da liberdade e do direito à integridade psicofísica, em prol do desenvolvimento da personalidade, realizar-se-ia como forma de evitar a discriminação; ou seja, acabaria

${ }^{692}$ Disponível em: <bvsms.saude.gov.br/bvs/saudelegis/gm/2008/prt1707_18_08_2008.html>, acesso em novembro de 2011.

${ }_{693}$ Temas de Direitos Humanos, cit., p. 237.

${ }^{694}$ MILLOT, Catherine. Extrasexo: ensaio sobre o transexualismo, cit., p. 115. 
consistindo em uma segunda violação de direitos, agora sobre a integridade física, de quem já se sentia discriminado por conta da identidade de gênero.

Emerge, destarte, a pressão que eventualmente pode levar os transexuais à cirurgia, movidos não pelo desejo da transformação corporal em si, mas em busca do reconhecimento de sua identidade de gênero, do que resultaria uma violação estatal traduzida pela necessidade de ser operado para ser reconhecido.

Há ainda outros aspectos a serem considerados, sobre a vida privada e sobre a importância da aparência, para a tutela da identidade.

Como visto, a identidade refere-se à definição do Ser moral, mas não se esgota na intimidade. Possui igualmente a finalidade de tornar o indivíduo conhecido por quem é, consistindo em projeção da individualidade que define o próprio $\mathrm{Eu}$.

Nesse diapasão, a identidade individual possui uma dupla dimensão. Uma primeira restrita ao resguardo e ao segredo, constitutivos da vida privada, âmbito em que se desenvolve o diálogo silencioso consigo mesmo no processo de individualização. A pessoa transexual, sob o ângulo da intimidade, define sua identidade baseada na convicção íntima de pertença ao outro sexo, identificando-se com o gênero oposto, não obstante a contradição com o sexo biológico.

A segunda dimensão, por sua vez, é relacional, construída na intersubjetividade, a partir das relações estabelecidas pelo sujeito no desenvolvimento de seus projetos. Consiste na expressão pública da pessoa, àquilo que é por ela exibido, pelo qual passa a ser conhecida pelos outros, na tessitura das relações humanas. Trata-se de tema que Hannah Arendt aprofundou, ao refletir sobre a condição humana da pluralidade, afirmando que cada um se afirma singular e se diferencia dos outros, por atos e palavras, revelando sua identidade. ${ }^{695}$

Nessa quadra, releva refletir sobre a importância da aparência na constituição da identidade no espaço público.

A relação entre o ser e o parecer é igualmente tratada por Hannah Arendt, para quem nossa percepção da realidade depende da aparência revelada no espaço público, tratando-se daquilo que pode ser visto e ouvido por todos e é comum a todos nós. 696

${ }^{695}$ ARENDT, Hannah. A condição humana. Tradução de Roberto Raposo. $10^{\mathrm{a}}$ ed. Rio de Janeiro: Forense Universitária, 2001, p. 189 e p. 196.

${ }^{696}$ Idem, p. 59/62. 
Segundo a autora, "Para nós, a aparência - aquilo que é visto e ouvido pelos outros e por nós mesmos - constitui a realidade". ${ }^{697}$ Acrescenta a filósofa a necessidade da existência de uma esfera pública e compartilhada por todos, para a própria consciência da existência, "uma vez que nossa percepção da realidade depende totalmente da aparência, e portanto da existência de uma esfera pública", ${ }^{698}$ relevante ao processo de efetivação da condição humana da pluralidade, "isto é, do viver como ser distinto e singular entre iguais". 699

Na concepção de Hannah Arendt, então, o espaço público é essencial, permitindo o compartilhamento de aparências comuns que, por isso, passam a constituir a realidade. Nas palavras da autora, "sem o espaço da aparência e sem a confiança na ação e no discurso como forma de convivência, é impossível estabelecer inequivocamente a realidade do próprio eu, da própria identidade, ou a realidade do mundo circundante". 700 É dizer, nossa identidade reveste-se de certeza e constitui-se como realidade perceptível a nós mesmos e aos outros na medida em que aparecemos e compartilhamos um espaço comum.

Na leitura aprofundada de Celso Lafer, da relevância atribuída à aparência emerge a importância da intersubjetividade, "pois tudo que é, na medida em que aparece, não existe isoladamente, no singular". ${ }^{701}$ Nesse sentido, reconhece o professor um caráter relacional do conhecimento, generalizável, baseado na percepção comum da realidade, que necessariamente inclui os outros.

Para o Estado, na regulação do convívio humano, quer parecer, importa a dimensão pública da identidade, a revelação da pessoa por atos e palavras e por aquilo que é compartilhado por todos, ou seja, a aparência, que constitui nossa base da realidade comum.

Resta, então, indagar se o órgão sexual do transexual não operado refere-se à dimensão privada ou pública da identidade, pretendendo-se estabelecer se pode ou não ser ocultado dos outros na definição da identidade de gênero.

A despeito de se cuidar de conformação física, tem-se certo que, na cultura ocidental, os órgãos sexuais da pessoa, não sem motivo denominados "partes íntimas”, não são aparentes, porquanto não integram a apresentação do indivíduo.

\footnotetext{
${ }^{697}$ Idem, p. 59.

${ }^{698}$ Idem, p. 61.

${ }^{699}$ Idem, p. 191.

${ }^{700}$ Idem, p. 220.

${ }^{701}$ A reconstrução dos direitos humanos, cit., p. 253.
} 
Por outro lado, os demais aspectos físicos que individualizam e constituem a aparência humana são públicos, como o rosto, o comprimento dos cabelos, a existência de pelos, a musculatura e a forma de vestir, por exemplo, diretamente indicativos do pertencimento da pessoa a determinado sexo. Por isso, a convicção íntima, o comportamento e a imagem da pessoa, levando a crer no gênero de identificação e convencendo de sua veracidade, passam a constituir nossa noção de realidade quanto ao sexo da pessoa.

Nesse contexto, vislumbram-se fundamentos para admitir a identidade de gênero independentemente da operação para mudança de sexo, no pressuposto de que a dimensão pública da identidade, sustentada por aquilo que efetivamente aparece aos outros e torna a pessoa conhecida, não inclui o órgão sexual.

A identidade relacional, nessa quadra, baseada no que efetivamente se revela, é comum e compartilhado no espaço público, independentemente das partes do corpo restritas à intimidade, autorizaria o reconhecimento da identidade sexual ao transexual não operado, no atendimento de sua reivindicação.

Essa ideia foi incorporada pelos autores dos Princípios de Yogyakarta, especialistas em legislação internacional de direitos humanos e em orientação sexual e identidade de gênero. Em reunião realizada na Indonésia, entre 6 e 9 de novembro de 2006, os participantes chegaram a conclusões consolidadas nos denominados Princípios, publicados em 2007. Os Princípios de Yogyakarta não possuem o status de Declaração de Direitos aprovada no âmbito internacional, mas reconhece-se sua importância como vetores de interpretação, na fixação das obrigações estatais. ${ }^{702}$

Reza o Princípio $\mathrm{n}^{\mathrm{o}} 3$, específico sobre o Direito ao Reconhecimento da Personalidade Jurídica: "Todo ser humano tem direito, em todas as partes, ao reconhecimento de sua personalidade jurídica. As pessoas, em sua diversidade de orientações sexuais ou identidades de gênero, desfrutam de capacidade jurídica em todos os aspectos da vida. A orientação sexual ou identidade de gênero que cada pessoa defina para si é essencial para sua personalidade e constitui um dos aspectos fundamentais de sua autodeterminação, sua dignidade e sua liberdade. Nenhuma pessoa será obrigada a $\underline{\text { submeter-se a procedimentos médicos, incluindo a cirurgia de redesignação de sexo, a }}$ esterilização ou a terapia hormonal, como requisito para o reconhecimento legal de sua

702 HAMMARBERG, Thomas. Human Rights and gender identity. Estrasburgo, 29/07/2009. CommDH/IssuePaper(2009). Item II: International Human Rights Law. Disponível em: <wcd.coe.int/ViewDoc.jsp?id=1476365>, último acesso em 02/02/2012. 
identidade de gênero. Nenhuma condição, como o matrimônio, a maternidade ou a paternidade, poderá ser invocada com o fim de impedir o reconhecimento legal da identidade de gênero de uma pessoa. Nenhuma pessoa será submetida a pressões para ocultar, suprimir ou negar sua orientação sexual ou identidade de gênero" (tradução livre) (sublinhei). ${ }^{703}$

No mesmo sentido, a orientação do Comissário de Direitos Humanos do Conselho da Europa. Entre as Recomendações aos Estados membros, o Comissário, em 2009, incluiu a abolição da "esterilização e outro tratamento médico compulsório como condição legal para o reconhecimento da identidade de gênero da pessoa, nas leis que regulamentem o processo para a mudança de nome e sexo" (tradução livre), ${ }^{704}$ claramente sinalizando a tendência de não vincular o fenótipo à identidade sexual.

Cabe salientar que essa concepção de identidade de gênero independente da anatomia do sexo foi recentemente adotada pela Corte Constitucional alemã. Em artigo intitulado "O reconhecimento da transexualidade", o professor Geraldo Miniuci traz os argumentos utilizados pela Corte ao decidir pela inconstitucionalidade da exigência legal de prévia cirurgia como condição para a mudança do sexo civil, objeto da Reclamação Constitucional BVerfG, 1 BvR 3295/07 vom 11.1.2011, Absatz-Nr.

No entender dos julgadores, as informações científicas atualmente disponíveis sobre o que é ser homem ou mulher inviabilizam a redução dessa definição a elementos biológicos da pessoa, admitindo que também devem ser considerados aspectos psicológicos, dependentes da autopercepção da pessoa sobre si e sobre seus sentimentos. Consignaram os magistrados, com base em dados estatísticos e na literatura especializada, que nem todo transexual deseja ser operado, e que há outras formas de tratamento, além da intervenção cirúrgica, não necessariamente o meio mais

\footnotetext{
${ }^{703}$ Principio 3. El derecho al reconocimiento de la personalidad jurídica: "Todo ser humano tiene derecho, en todas partes, al reconocimiento de su personalidad jurídica. Las personas en toda su diversidad de orientaciones sexuales o identidades de género disfrutarán de capacidad jurídica en todos los aspectos de la vida. La orientación sexual o identidad de género que cada persona defina para sí, es esencial para su personalidad y constituye uno de los aspectos fundamentales de su autodeterminación, su dignidad y su libertad. Ninguna persona será obligada a someterse a procedimientos médicos, incluyendo la cirugía de reasignación de sexo, la esterilización o la terapia hormonal, como requisito para el reconocimiento legal de su identidad de género. Ninguna condición, como el matrimonio o la maternidad o paternidad, podrá ser invocada como tal con el fin de impedir el reconocimiento legal de la identidad de gênero de una persona. Ninguna persona será sometida a presiones para ocultar, suprimir o negar su orientación sexual o identidad de género"(sublinhei). In Introducción a los princípios de yogyakarta, p. 12. Disponível em:www.yogyakartaprinciples.org/principles_sp.pdf, último acesso em 02/01/2012.

704 V. Recommendations to Council of Europe member states. (...)4. Abolish sterilisation and other compulsory medical treatment as a necessary legal requirement to recognise a person's gender identity in laws regulating the process for name and sex change”. In HAMMARBERG, Thomas. Human Rights and gender identity. Estrasburgo, 29/07/2009. CommDH/IssuePaper(2009). Disponível em: <wcd.coe.int/ViewDoc.jsp?id=1476365>, último acesso em 02/02/2012
} 
eficiente para apaziguar o conflito de identidade. Por reconhecerem que se trata de operação bastante agressiva, entenderam pela impossibilidade de vincular o gozo do direito à autodeterminação sexual a uma violação à integridade física, pois "não se admite que um direito fundamental se realize às expensas de outro direito fundamental". ${ }^{705}$ A partir daí, "decidiu a corte que a qualificação jurídica de um transexual não poderá mais depender de pressupostos invasivos e agressivos como uma cirurgia. A prova de que o desejo do transexual é estável e irreversível haverá de ser obtida após um processo de análise de diversos elementos psicossociais e médicos". 706

No Brasil, o tema foi objeto do $2^{\circ}$ Curso de Especialização em Direito de Família e Sucessões promovido pela Escola Paulista da Magistratura - EPM, decidindo-se, em grupo de discussão, pela possibilidade do reconhecimento da identidade de gênero independentemente da cirurgia. Na transcrição do teor da conclusão: "Sendo comprovada por perícia médica a situação de transexualidade da pessoa, mesmo sem cirurgia reparadora, a pessoa pode ter seu nome e sexo alterados por decisão judicial, a fim de assegurar sua real identificação de gênero". 707

Propõe-se, assim, uma abordagem da transexualidade sob a ótica do conflito identitário inserido na temática dos direitos humanos, dispensando a intervenção cirúrgica e permitindo o exercício do direito à integridade psicofísica em sua dupla face: pela possibilidade de recusar a operação e evitar uma violação ao próprio corpo e, ao mesmo tempo, obter a adequação do sexo no assento civil, no apaziguamento do elemento psicológico.

$\mathrm{Na}$ dicção de Berenice Bento ao tratar da influência da compreensão da transexualidade pelo legislador, para o conteúdo das leis: "Quanto mais próximo de uma visão patologizante, maiores serão as exigências para que a pessoa transexual tenha direitos, e quanto maior a compreensão de que a transexualidade se insere no campo do conflito identitário e dos direitos humanos, menores serão os obstáculos". 708

No mais, as consequências jurídicas da mudança no estado civil, tanto do transexual operado quanto do não operado, serão analisadas à parte, em item próprio, referente aos reflexos do direito à identidade de gênero ou sexual.

${ }^{705}$ MINIUCI, Geraldo. O reconhecimento da transexualidade. Artigo publicado na $31^{\text {a }}$ edição do jornal Estado de Direito, de 17/08/2011. Disponível in: www.estadodedireito.com.br/2011/08/17/oreconhecimento-da-transexualidade/, último acesso em 03/01/2012.

${ }^{706}$ Idem, mesmo endereço eletrônico.

${ }^{707}$ Enunciado extraído da aula proferida pelo Desembargador Euclides de Oliveira, em 03/09/09, na Escola Paulista da Magistratura, publicado no Diário de Justiça Eletrônico/SP, de 18/12/2009, Caderno Administrativo, p. 29.

${ }^{708}$ O que é transexualidade. São Paulo: Editora Brasiliense, 2008, p. 113/114. 


\section{7) A tutela da segurança jurídica e da ordem pública no} reconhecimento do direito à identidade de gênero ou sexual

A possibilidade de autorizar a mudança do estado civil, exigindo-se ou não prévia cirurgia, não se confunde com liberdade ilimitada em relação à escolha do sexo.

Sob esse aspecto, cabe lembrar que o direito à identidade de gênero não é absoluto, devendo ser respeitados os limites próprios dos direitos da personalidade, como a dignidade da pessoa humana e a ordem pública, ${ }^{709}$ para evitar o risco de banalização da mudança do estado civil.

Nesse passo, reafirma-se uma compreensão da identidade sexual como uma projeção da pessoa e como forma de expressão de sua personalidade diretamente conectada com a dignidade, não se confundindo com um bem acessório, passível de aquisição. Assim, vedam-se alterações fora das hipóteses em que comprovada a identificação com o gênero oposto, de modo seguro e estável.

Para alcançar a segurança necessária para promover tão séria modificação pode ser dispensada a submissão da pessoa à intervenção cirúrgica, no pressuposto de que existem outros mecanismos de aferição da estabilidade da identificação de gênero.

Tome-se, por exemplo, o Teste da Vida Real (Real Life Experience), proposto pela HBIGDA (Harry Benjamin International Gender Dysphoria Association). Por meio da experiência, pretende-se avaliar aspectos relacionados ao trabalho, aos estudos e à atividade da pessoa na comunidade, pressupondo desde logo uma identidade legal com o nome adequado ao novo gênero. ${ }^{710}$

Não se trata de etapa do diagnóstico, mas de recomendação para que a pessoa, sofredora do conflito de identidade, sinta o impacto de viver como alguém pertencente ao outro sexo. ${ }^{711}$

Os parâmetros fixados pela Associação Harry Benjamin deixam bem claro também que a cirurgia, ao lado da terapia hormonal e da experiência da vida

\footnotetext{
${ }^{709}$ PERONA, Javier López-Galiacho. La problemática jurídica de la transexualidad, cit., p. 125.

${ }^{710}$. Parameters of the real-life, in Standards of care for gender identity disorders, sixth version, 2001, p. 17. Disponível em: www.wpath.org/Documents2/socv6.pdf, último acesso em 19/11/2011.

${ }^{711}$ Real-life experience versus real-life test, in Standards of care for gender identity disorders, sixth version, 2001, p. 18. Disponível em: www.wpath.org/Documents2/socv6.pdf, último acesso em 19/11/2011.
} 
real, consiste em uma forma de tratamento, ${ }^{712}$ a corroborar a caracterização da transexualidade independentemente da operação e, portanto, a necessidade de encontrar mecanismos jurídicos que permitam a tutela da identidade dos transexuais não operados.

A preservação da ordem pública e da segurança jurídica na regulamentação da identidade de gênero encontra fundamentos diversos, além daqueles baseados na anatomia do sexo, como se percebe pelas exposições de motivos das leis europeias que autorizam a mudança civil independentemente da prévia cirurgia.

Como consignado na Exposição de Motivos da Lei Espanhola $\mathrm{n}^{\circ}$ 3/2007, as retificações autorizadas dirigem-se a regularizar mudanças de identidade de gênero já ocorridas e consolidadas perante a sociedade, no pressuposto de que a pessoa já viva como alguém do sexo oposto antes mesmo de obter a alteração do registro, de modo a garantir a segurança jurídica e a ordem pública. ${ }^{713}$

Idêntico o teor da Exposição de Motivos do Projeto de Lei Português n ${ }^{\circ}$ 319/XI, apresentado pelo Bloco de Esquerda antes da aprovação da Lei $n^{\circ}$ 07/2011. Segundo seus autores, o Projeto objetivava positivar no ordenamento Português a interpretação do Tribunal da Relação de Lisboa, segundo a qual "o registo, enquanto forma de dar publicidade a certos factos, deles constando certas características, consideradas relevantes, só tem valor e interesse para a Sociedade em Geral, sua destinatária principal, se esse mesmo registo estiver conforme à realidade. Se do registo constar algo que não tenha correspondência com a realidade, ele torna-se, em vez de um factor de estabilidade social, um elemento de conflito, porque enganoso", concluindo que "o que releva socialmente é o seu comportamento, o modo como se vê frente aos outros seres humanos, particularmente no domínio do relacionamento em função do sexo, e da forma como é visto pelos outros" (Tribunal da Relação de Lisboa, Ac. 22 de junho de 2004, Ref. $3607 / 2004)^{714}$

Nessa dicção, a proteção da ordem pública e da segurança jurídica é alcançada pela confirmação da expectativa criada pela aparência, modo de vida e relações sociais da pessoa, prevalecentes sobre o aspecto biológico do sexo, no reconhecimento da identidade de gênero. A anotação do novo sexo no assento civil, outrossim, responde à confiança inspirada pelos atos e palavras que confluem na dimensão

${ }^{712}$ Sex Reassignment is Effective and Medically Indicated in Severe GID, in Standards of care for gender identity disorders, sixth version, 2001, p. 18. Disponível em: www.wpath.org/Documents2/socv6.pdf, último acesso em 19/11/2011.

${ }^{713}$ MORENO, Yolanda B. Bustos. La transexualidad, cit., p. 34/35.

${ }^{714}$ Projecto de Lei no 319/XI, Exposição de Motivos, Disponível em: 〈www.parlamento.pt〉, acesso em $31 / 08 / 2011$. 
pública e relacional da identidade, revestindo de segurança e certeza as relações jurídicas já entabuladas.

Nota-se, outrossim, que a irreversibilidade da identificação com o gênero oposto como condição para a retificação registrária é preocupação comum mesmo nos países que não exigem a intervenção cirúrgica.

Esse o entendimento consagrado pela Recomendação 1117, da Assembleia do Conselho da Europa, segundo a qual não se deve permitir a retificação do sexo no registro na hipótese da transexualidade reversível, em razão da amplitude dos efeitos daí advindos, a afastar o caráter voluntário de tal retificação. ${ }^{715}$

\section{8) $\mathrm{O}$ direito à identidade de gênero independentemente da} cirurgia de redesignação do sexo, na legislação comparada

A perspectiva que propõe o trato jurídico da transexualidade pela ótica dos direitos humanos, permitindo o reconhecimento do gênero de identificação independentemente da realização da cirurgia, foi adotada em algumas das legislações europeias mais recentes sobre o tema.

A exigência da cirurgia irreversível, nos termos dos art. $1^{\mathrm{o}} \mathrm{e}$ art. $3^{\circ}$, da Lei Italiana $n^{\circ} 164$, de 14/04/1982, ${ }^{716}$ como condição para a mudança no registro oficial de nascimento, não mais se faz presente na lei inglesa, na espanhola, ou na portuguesa, percebendo-se que os mais de trinta anos transcorridos desde a vigência da lei sueca de 1972 até a promulgação do Gender Recognition Act do Reino Unido, em 2004, produziram efeitos no que toca à compreensão jurídica da transexualidade, sob o aspecto da identidade de gênero.

Em busca de alinhar os países que não exigem a adaptação cirúrgica do sexo para o reconhecimento da identidade de gênero, além da Espanha e recentemente de Portugal, aponta Yolanda Moreno a Holanda, a Áustria e o Reino Unido. Contrariamente, lembra a autora que a cirurgia é exigida na Alemanha, na França e na

\footnotetext{
${ }^{715}$ MORENO, Yolanda B. Bustos. La transexualidad, cit., p. 178.

716 “'Art. 1. La rettificazione di cui all'art. 454 del codice civile si fa anche in forza di sentenza del tribunale passata in giudicato che attribuisca ad una persona sesso diverso da quello enunciato nell'atto di nascita a seguito di intervenute modificazioni dei suoi caratteri sessuali". "Art. 3. Il tribunale, quando risulta necessario un adeguamento dei caratteri sessuali da realizzare mediante trattamento medico-chirurgico, lo autorizza con sentenza. In tal caso il tribunale, accertata la effettuazione del trattamento autorizzato, dispone la rettificazione in camera di consiglio”.
} 
Suécia. ${ }^{717}$ A Lei belga $\mathrm{n}^{\mathrm{o}}$ 10/55, de 10 de maio de 2007, igualmente manteve a submissão à operação como condição, em seu art. $2^{\circ}, \S 2^{\circ}, 1^{\circ}$ e $2^{\circ}$. 718

Simona Luciani, ${ }^{719}$ ao esboçar o contexto normativo europeu sobre a transexualidade, aponta a existência de um sistema flexível na Alemanha, que permite uma "pequena solução", por natureza reversível, e uma "grande solução", definitiva. A "pequena solução", segundo a autora prevista também na Holanda e na Áustria, permite a obtenção apenas da mudança do nome, sem qualquer alteração do gênero no registro civil, exigindo como requisito a pressuposição de que a aparência pertencente ao novo sexo não será mais modificada. ${ }^{720}$ Por outro lado, a mesma lei permite ao requerente a possibilidade de retroceder, ou seja, de voltar a usar o nome original (art. $10){ }^{721}$

No sistema alemão, a "grande solução", por sua vez, implica a alteração do sexo no registro civil, exigindo que a pessoa não esteja casada e a intervenção cirúrgica modificadora dos caracteres sexuais externos, como condição. ${ }^{722}$

A solução legislativa encontrada na Holanda, por lei de 24/04/1985, permite a mudança do sexo no registro à pessoa que ostente a firme convicção de pertencer ao sexo oposto, solteira e incapaz de gerar. ${ }^{723}$ Na Turquia, a lei de 11/05/1988 autoriza a alteração no registro, em caso de mudança de sexo constatada por comissão médica, determinando a intervenção do cônjuge no processo em caso do transexual ser casado. $^{724}$

\footnotetext{
${ }^{717}$ MORENO, Yolanda B. Bustos. La transexualidad, cit., p. 164/165.

718 “\$ 2. Lors de la déclaration, l'intéressé remet à l'officier de l'état civil une déclaration du psychiatre et $d u$ chirurgien, en qualité de médecins traitants, attestant: $1^{\circ}$ que l'intéressé a la convicion intime, constante et irréversible d'appartenir au sexe opposé à celui qui est indiqué dans l'acte de naissance; $2^{\circ}$ que l'intéressé a subi une réassignation sexuelle qui le fait correspondre au sexe opposé, auquel il a la conviction d'appartenir, dans toute la mesure de ce qui est possible et justifié du point de vue médical".

${ }^{719}$ LUCIANI, Simona. Transizioni familiari. Transessualimo, genitorialità e tutela del minore. Publicação virtual do Interattivamente. Centro di Psicologia Giuridica - Sessuologia Clinica - Psicoterapi. Disponível em: www.interattivamente.org/index.php/articoli-libri-e-recensioni/58-transizioni-familiari-transessualismogenitorialita-e-tutela-del-minore>, último acesso em 26/12/2011.

${ }^{720}$ A lei alemão transgendergesetz foi consultada em sua tradução para o italiano: Legge per la scelta o il cambio di nome e per la determinazione del sesso di appartenenza. Legge teddesca, disponível in www.azionetrans.it/leggetedesca.html, acesso em 10/09/2011: "art. 6: Cambiamento del nome in caso di disforia di genere -(..)Requisiti sono: essere cittadini tedeschi (ou residente, ou com permissão de permanecer no país por tempo indeterminado); E'inoltre da presupporre che la scelta di appartenenza all'altro sesso non verrà più modificata.

721 "art. 10: Diritto di retrocedere - Dalla decisione di cambiamento di nome si può retrocedere tramite richiesta scritta, se il richiedente sente in realtà di appartenere al sesso di origine".

${ }^{722}$ MORENO, Yolanda B. Bustos. La transexualidad, cit., p. 165.

${ }^{723}$ PERONA, Javier López-Galiacho. La problemática jurídica de la transexualidad, cit., p. 154.

${ }^{724}$ Idem, p. 154/155.
} 
Na França, embora não haja legislação específica, o Tribunal de Cassação Francês, a partir de 1992 e após a condenação daquele país pela Corte Europeia de Direitos Humanos, passou a admitir a mudança de nome e sexo no registro civil com base no respeito à vida privada, consagrado no art. $8^{\circ}$, da Convenção Europeia de Direitos Humanos, embora exigindo a submissão da pessoa à intervenção cirúrgica. ${ }^{725}$

Sessarego cita a Áustria e a Diamarca entre os países que preveem soluções pragamáticas e administrativas, independentemente de lei, e a Suíça como o local em que se atribui ao Poder Judiciário decidir sobre a mudança de sexo, em razão do vácuo legal. ${ }^{726}$

No sistema americano da Common Law, admite-se a alteração do registro, após a operação para a mudança de sexo, nos Estados de Illinois, Arizona, Lousiana e Califórnia, em diversas províncias do Canadá, na África do Sul, na Austrália e em Israel. $^{727}$

Nos termos do art. 1, (a), do Gender Recognition Act inglês, o requerimento para a mudança de sexo pode ser feito pela pessoa maior de 18 anos que esteja vivendo de acordo com o outro gênero, dispensando-se a cirurgia como condição: “(I) A pessoa de qualquer gênero que tenha no mínimo 18 anos pode fazer a solicitação do certificado de reconhecimento de gênero, sob o argumento de (a) estar vivendo de acordo com o outro sexo ou (b) ter mudado de gênero de acordo com a lei de país ou território fora do Reino Unido" (tradução livre). ${ }^{728}$

Perante a legislação inglesa, a estabilidade da identificação com o outro sexo pressupõe a demonstração de que a pessoa: 1) sofre ou sofreu de disforia de gênero comprovada por relatório médico; 2) vive de acordo com o gênero desejado há pelo menos dois anos completos na data do requerimento; e 3) pretende continuar a viver de acordo com o sexo de identificação até a morte (item 2 (1) e 3 (1), do Gender Recognition $A c t) .{ }^{729}$ Exige-se que a pessoa tenha se submetido ou esteja se submetendo a tratamento

\footnotetext{
${ }^{725}$ MORENO, Yolanda B. Bustos. La transexualidad. cit., p. 34 e p. 164/165.

${ }^{726}$ SESSAREGO, Carlos Fernández. El cambio de sexo y su incidencia en las relaciones familiares, cit., p. 36.

${ }_{727}$ PERONA, Javier López-Galiacho. La problemática jurídica de la transexualidad. cit., p. 155/156.

728 " (1) A person of either gender who is aged at least 18 may make an application for a gender recognition certificate on the basis of (a) living in the other gender, or (b) having changed gender under the law of a country or territory outside the United Kingdom".

${ }^{729}$ Diponível em: < www.legislation.gov.uk/ukpga/2004/7/section2 >, último acesso em 19/11/2011: (1) In the case of an application under section 1(1)(a), the Panel must grant the application if satisfied that the applicant (a) has or had gender dysphoria, (b) has lived in the acquired gender throughout the period of two years ending with the date on wich the application is made, (c) intends to continue to live in the acquired gender until death, and (d) complies with the requirements imposed by and under section 3.
} 
para a modificação das características sexuais e que tal tratamento tenha sido prescrito ou planejado. $^{730}$

Em 2007 foi promulgada a Lei Espanhola de Identidade de Gênero, no 3/2007. De acordo com a referida lei, é legitimada para requerer a alteração do sexo no registro de nascimento toda pessoa de nacionalidade espanhola, maior de idade e capaz $\left(\operatorname{art} .1^{\circ}\right.$ ). Os requisitos para tanto estão estabelecidos no art. $4^{\circ}$ e incluem o diagnóstico de disforia de gênero subscrito por médico ou psicólogo que ateste sua estabilidade e persistência (art. 4.1), além de tratamento médico por no mínimo dois anos, para a adequação das características físicas ao sexo reclamado, expressamente ressalvandose no art. 4.2: "Não será necessário para a autorização da retificação do sexo de uma pessoa no registro que o tratamento médico tenha incluído cirurgia de redesignação sexual" (tradução livre). ${ }^{731}$

Em Portugal, a Lei $n^{\text {o } 7 / 2011, \text { publicada em 15/03/2011, }}{ }^{732}$ criadora do "procedimento de mudança de sexo e de nome próprio no registo civil", estabelece que podem requerer a alteração de nome e sexo as pessoas maiores de 18 anos que apresentem diagnóstico de perturbação de identidade de gênero e que não se mostrem interditas ou inabilitadas por anomalia psíquica (art. $2^{\circ}$ ). O pedido, apresentado diretamente ao cartório, pode incluir desde logo o requerimento da lavratura de um novo assento de nascimento, devendo estar acompanhado de relatório subscrito por no mínimo um médico e um psicólogo, comprobatório da transexualidade (art. $3^{\circ}, 1$ e 2), sem qualquer alusão à necessidade de realização de cirurgia.

Mais claro o Projeto de Lei Argentino, Expediente $n^{\circ} 1736-\mathrm{D}-$ 2009, em tramitação na Câmara dos Deputados sob nº 029 (16/04/2009), cujo art. $8^{\circ}$ exige que se demonstre, por qualquer meio de prova, a existência da dissonância entre o sexo e o nome do registro e a identidade de gênero percebida pelo demandante, de modo estável e persistente, dispensando tal demonstração na hipótese de a pessoa ter se submetido à cirurgia de redesignação, acrescentando que “em nenhum caso será exigida a cirurgia de redesignação sexual para obter a retificação no registro do sexo e a mudança do nome" (tradução livre). ${ }^{733}$ Como noticiado pela imprensa, tal projeto de lei de identidade de

\footnotetext{
${ }^{730}$ MORENO, Yolanda B. Bustos. La transexualidad. cit., p. 164.

731 “4.2. No será necesario para la concesión de la rectificación registral de la mención del sexo de una persona que el tratamiento médico haya incluido cirugía de reasignación sexual".

${ }^{732}$ Disponível em: <dre.pt/pdf1sdip/2011/03/05200/0145001451.pdf>, último acesso em 20/11/2011.

${ }^{733}$ Artículo 8o: Son requisitos indispensables para acceder a la rectificación registral del sexo y cambio de nombre, que se constate: -La existencia de disonancia entre el sexo y el nombre inicialmente inscrito y la identidad de género autopercibida por la persona solicitante. - La estabilidad y persistencia de esta
} 
gênero foi aprovado na Câmara de Deputados por cento e dezessete votos a favor, dezessete contra e sete abstenções, em 30/11/2011, seguindo para o Senado, onde se encontra pendente de votação. ${ }^{734}$

Por fim, cabe anotar particularidade trazida no art. 4.2.2, lei espanhola, ao autorizar a alteração do nome e sexo da pessoa independentemente de qualquer transformação física. Trata-se da hipótese em que a alteração está impossibilitada por contraindicação médica ou em razão da idade do paciente. ${ }^{735}$ Nessa situação, diagnosticada a transexualidade e a impossibilidade de modificação corporal decorrente de fatores ligados à saúde, permite-se a alteração. Na análise de Yolanda Moreno, a lei sinaliza, assim, a superioridade do elemento psíquico sobre o físico, considerando suficiente a irreversibilidade da identificação psicológica, que tende a prevalecer. ${ }^{736}$

Por outro lado, lembra a autora que a Convenção nº 29 , adotada pela Assembleia Geral de Lisboa, em 16/09/1999, figurando como Estados signatários os membros da Comissão Internacional do Estado Civil, relativa ao reconhecimento das decisões entre países, permite que a alteração de sexo realizada em um Estado não seja reconhecida em outro, na hipótese de a adaptação física não ter sido realizada, anotando que tal convenção não foi ratificada pela Espanha. ${ }^{737}$

Pelo exposto, percebe-se que a exigência da cirurgia como condição para o reconhecimento da identidade de gênero ou sexual, mediante a retificação do nome e sexo no assento de nascimento do transexual, é questão que não encontra o mesmo tratamento nos países que expressamente legislaram sobre o tema, observando-se a tendência de dispensar a cirurgia nas legislações mais recentes, como a Espanhola (2007) e a Portuguesa (2011).

disonancia. La persona solicitante podrá aportar, a efectos de dicha constatación, todo medio de prueba fehaciente. No serán exigidos los requisitos precedentes cuando la persona haya procedido a la cirugía de redesignación sexual. En ningún caso se exigirá cirugía de reasignación sexual para acceder a la rectificación registral del sexo y cambio de nombre. Disponível in: <www.lgbt.org.ar/archivos/1736_Identidad_Augsburger.pdf >, acesso em 31/08/2011).

734 Jornal O Estado de São Paulo, edição de 02/12/201, p. A 26; notícia também disponível em: <noticias.r7.com/internacional/noticias/câmara-argentina-aprova-projeto-para-facilitar-mudanca-de-sexo-emdocumento-20111201.html>, último acesso em 12/12/2011.

735 “Art. 4.2.2. ...Los tratamientos médicos a los que se refiere la letra b) del apartado anterior no serán un requisito necesario para la concesión de la rectificación registral cuando concurran razones de salud o edad que imposibiliten su seguimiento y se aporte certificación médica de tal circunstancia”.

${ }_{736}$ MORENO, Yolanda B. Bustos. La transexualidad. cit., p. 174.

${ }^{737}$ Idem, p. 176 e $347 / 350$ (íntegra da Convenção). 
9) $\mathrm{O}$ direito à identidade de gênero ou sexual no Brasil: a ação dos Poderes Legislativo, Executivo e Judiciário

\section{9.a) A regulação da transexualidade pelo Poder Legislativo}

No Brasil, o primeiro Projeto de Lei sobre a transexualidade, $\mathrm{n}^{\circ}$ 70/1995, de autoria do Deputado Federal José Coimbra, destinava-se a regulamentar a mudança de prenome do transexual que tivesse se submetido à operação para mudança de sexo, determinando a anotação no registro civil de que se tratava de transexual. Na Comissão de Constituição e Justiça, o Projeto recebeu duas emendas de autoria do Deputado Régis de Oliveira, uma determinando a lavratura de novo registro de nascimento, com o novo nome e sexo, e outra, vedando a expedição de certidão, salvo a pedido do interessado ou por ordem judicial. ${ }^{738}$

Encontra-se em apenso ao referido Projeto o Projeto $\mathrm{n}^{\circ}$ 2.976/2008, que cria a possibilidade de se adotar no registro público um nome social ao lado do oficial; e o Projeto $\mathrm{n}^{\circ} 1281 / 2011$, que dispõe sobre a mudança de prenome da pessoa transexual que realizar cirurgia para a mudança de sexo. Não há qualquer previsão quanto à alteração do estado civil.

Em 21/02/2006, foi apresentado o Projeto de Lei $n^{\circ}$ 6.655/2006, aprovado por unanimidade na Câmara, em 21/08/2007, e enviado ao Senado em 12/09/2007, com proposta de alteração do art. 58, da Lei n ${ }^{\circ}$ 6.015/73 (Lei dos Registros Públicos), para incluir a hipótese de alteração do prenome decorrente de transexualidade no inciso I. Sua principal diferença consiste em admitir a substituição do prenome da pessoa reconhecida como transexual por laudo médico, mediante sentença, "ainda que não tenha sido submetido a procedimento médico-cirúrgico destinado à adequação dos órgãos sexuais". 739

Ainda que se vislumbre avanço no trato da transexualidade no curso do processo legislativo, trata-se de resultados ainda tímidos, mormente se comparados com as mais recentes legislações europeias.

No Brasil, existem apenas Projetos de lei, sem qualquer alusão à mudança de sexo, o que indica longo caminho a percorrer. Assim, percebe-se que não há,

\footnotetext{
${ }^{738}$ Projeto e emendas disponíveis em: <Imagem.camara.gov.br/Imagem/D/0/5/1/D000050375.TIF>, último acesso em 31/10/2011.

${ }^{739}$ Disponível em

<www.camara.gov.br/proposicoesWeb/prop_mostrarintegra?codteor=377166\&filename=PL+6655/2006 >, último acesso em 31/10/2011.
} 
no direito brasileiro, norma aprovada ou sequer em tramitação que preveja solução para a identidade de gênero dos transexuais.

Cabe anotar que, a par das propostas para a mudança do nome mediante a alteração da Lei dos Registros Públicos, uma regulamentação da transexualidade no âmbito dos direitos da personalidade melhor contribuiria para a tutela dos transexuais sob a ótica dos direitos humanos.

Para tanto, uma sugestão seria incluir no Projeto de Lei nº 6960 (Projeto Fiuza), reapresentado pelo deputado Léo Alcântara sob nº 276/2007, a identidade de gênero ou sexual, entre os direitos da personalidade, nas alterações proposta para o art. 11 do Código Civil.

De acordo com o Projeto, o caput do art. 11 do Código Civil passaria a ter a seguinte redação: "O direito à vida, à integridade físico-psíquica, à identidade, à honra, à imagem, à liberdade, à privacidade, à opção sexual e outros reconhecidos à pessoa são natos, absolutos, intransmissíveis, indisponíveis, irrenunciáveis, ilimitados, imprescritíveis, impenhoráveis e inexpropriáveis". 740

É verdade que as menções à identidade e à opção sexual, esta aparentemente mais ampla do que a orientação sexual, poderão ser utilizadas em interpretações favoráveis aos direitos dos transexuais. Contudo, mesmo assim, melhor seria a inclusão expressa do direito à identidade de gênero ou sexual entre os direitos da personalidade, de modo a deixar expresso o reconhecimento jurídico que se faz necessário.

Nessa esteira, cabe anotar que a ausência de lei não deixa de consubstanciar forma de discriminação, na medida em que a ignorância da realidade pelo legislador acaba por manter a marginalização e perpetuar a invisibilidade da violação de direitos daqueles que não são ignorados e, consequentemente, não reconhecidos.

Como ensina Flavia Piovesan, "persiste, contudo, uma lamentável lacuna na legislação brasileira, no tocante à discriminação de que são vítimas as mulheres, os homossexuais, os adolescentes, as pessoas portadoras do vírus HIV e outros grupos socialmente vulneráveis", do que resulta a "necessidade de avançar mais no campo legislativo nacional, a fim de que todas as formas de discriminação sejam efetivamente punidas". 741

\footnotetext{
www.camara.gov.br/proposicoesWeb/fichadetramitacao?idProposicao=343231, último acesso em $05 / 01 / 2012$

${ }^{741}$ PIOVESAN, Flavia. Temas de Direitos Humanos. $3^{a}$ ed. São Paulo: Saraiva, 2009, p. 188/189.
} 


\section{9.b) Ações do Poder Executivo: A regulação do uso do nome}

social e o estabelecimento da Política Nacional de Saúde Integral de Lésbicas, Gays, Bissexuais, Travestis e Transexuais (Política Nacional de Saúde Integral - LGBT)

Podem ser apontadas ações do Poder Executivo, voltadas ao reconhecimento da identidade sexual ou de gênero, a indicar o sentido progressivo da afirmação do direito.

Em Belo Horizonte, a Resolução nº 002/2008, do Conselho Municipal, estabeleceu, em seu art. $1^{\circ}$, a obrigação de inclusão nos registros dos diários de turma, nos boletins escolares e demais registros das instituições de ensino, entre parênteses e na frente do nome constante do registro civil, o nome social pelo qual o transexual se identifica, ou prefere ser chamado $\left(\operatorname{art} .1^{\circ}\right)$. As justificativas para tanto incluem caber à escola assegurar a presença e a permanência do aluno, zelando pelo respeito às diferenças individuais e tendo em vista o desafio de despertar o espírito de inclusão e a preocupação da escola com a formação plena de todos os alunos, independentemente de raça, cor, sexo, credo, religião, identidade de gênero ou orientação sexual (art. $2^{\circ}$ ).

No mesmo sentido, a Resolução n ${ }^{\circ}$, do Conselho Estadual de Educação de Goiás, de 03/04/2009, determina que as escolas incluam o nome social do transexual nos registros escolares internos, entendendo como nome social "a forma pela qual travestis e transexuais se reconhecem, são identificados, são reconhecidos e são denominados por sua comunidade e em sua inserção social" (art. $\left.1^{\circ}, \S 1^{\circ}\right)$.

No Estado de São Paulo, o Decreto Municipal $n^{\circ}$ 51.180, de 14/01/2010, dispõe sobre a inclusão do nome social do transexual e travesti nos registros municipais relativos a serviços prestados no âmbito da Administração Direta e Indireta, inclusive em crachás e documentos de identificação, estabelecendo o dever da Administração, de respeitar o nome social, "usando-o para se referir a essas pessoas, evitando, no trato social, a utilização do respectivo nome civil” (art. $3^{\circ}$ ).

No nível estadual, por sua vez, foi promulgado o Decreto $\mathrm{n}^{\circ}$ 55.588, em 17 de março de 2010, para disciplinar o tratamento nominal das pessoas transexuais e travestis nos órgãos públicos do Estado de São Paulo. Admitiu, entre seus Consideranda, a necessidade de ações efetivas do Estado para assegurar a inclusão social da população LGBT, reconhecendo "que toda pessoa tem direito ao tratamento correspondente a seu gênero".

No âmbito Federal, a Portaria $\mathrm{n}^{\mathrm{o}}$ 233, de 18/05/2010, do Ministério do Planejamento, Orçamento e Gestão, assegurou aos servidores públicos da 
Administração Pública Federal direta, autárquica e fundacional o uso do nome social adotado por travestis e transexuais (art. $1^{\circ}$ ), nas situações de cadastros, comunicações internas, correio eletrônico, crachá, lista de ramal do órgão e nome de usuário em sistema de informática $\left(\operatorname{art} .2^{\circ}\right)$.

Em que pese o sentido de reconhecimento que se revela nas normas do Executivo, ainda há trilha a percorrer para o efetivo reconhecimento do direito ao nome como correlato à identidade assumida pelo transexual, considerando que todas restringem o uso do nome social ao âmbito interno da escola ou órgão, mantendo o uso do nome civil nos documentos oficiais, como históricos escolares, certificados, diplomas, ou mesmo no verso dos crachás.

Além disso, tais normas limitam-se à admissão do uso do nome pelo qual o transexual é identificado, sem qualquer menção a respeito do sexo, cujo reconhecimento também consiste, como visto, em pretensão essencial para a tutela de sua dignidade.

No âmbito da saúde, o Ministério da Saúde instituiu a Política Nacional de Saúde Integral LGBT, pela Portaria MS/GM n 2.836 , de $1^{\circ}$ de dezembro de $2011,{ }^{742}$ em observância às determinações da $13^{a}$ Conferência Nacional de Saúde, para que fossem observadas a orientação sexual e a identidade de gênero na análise da determinação social da saúde. Entre os Consideranda, foram incluídas a preocupação com a discriminação que incide na determinação social da saúde, no processo de sofrimento e adoecimento decorrente do preconceito e do estigma social dirigido à população LGBT, o desenvolvimento social como condição imprescindível para a conquista da saúde, a necessidade de ampliação do processo transexualizador já instituído no âmbito do SUS e a "necessidade de fomento de ações e serviços de saúde que visem à superação do preconceito e da discriminação, por meio da mudança de valores, baseada no respeito às diferenças" (último Considerando).

Institui entre os objetivos específicos da Política Nacional de Saúde Integral LGBT estabelecidos no art. $2^{\circ}$, entre outros: VI) garantir acesso ao processo transexualizador na rede do SUS, nos moldes regulamentados e XXI) incluir ações educativas nas rotinas dos serviços de saúde voltadas à promoção da autoestima e eliminação do preconceito por orientação sexual, identidade de gênero, raça, cor e território.

\footnotetext{
${ }^{742}$ Disponível em: www.cremesp.org.br/library/modulos/legislacao/versao impressao.php?id=10395, último acesso em 12/12/2011.
} 
Estabelece como diretrizes dos planos, programas, projetos e ações da saúde (art. $3^{\circ}$ ), entre outras: "VII) inclusão da temática da orientação sexual e identidade de gênero de lésbicas, gays, bissexuais, travestis e transexuais, nos processos de educação permanente desenvolvidos pelo SUS, incluindo os trabalhadores da saúde, os integrantes dos Conselhos de Saúde e as lideranças sociais".

Por fim, no reconhecimento da identidade sexual como aspecto da personalidade e zelando pela proteção dos transexuais contra a violência e discriminação, o art. $4^{\circ}, X$, da Portaria, estabelece que compete ao Ministério da Saúde "incluir os quesitos de orientação sexual e de identidade de gênero, assim como os quesitos de raça-cor, nos prontuários clínicos, nos documentos de notificação de violência da Secretaria de Vigilância em Saúde do Ministério da Saúde (SVS/MS) e nos demais documentos de identificação e notificação do SUS".

\section{9.c) $O$ direito à identidade sexual na jurisprudência}

Os Tribunais têm reconhecido a identidade sexual como um bem jurídico a ser protegido, entre os direitos da personalidade.

Em decisão transitada em julgado em 07/12/2009, que deu provimento a Recurso Especial para permitir a alteração do nome e do sexo do transexual no registro civil, a Relatora consignou: "E a tendência mundial é a de alterar-se o registro adequando-se o sexo jurídico ao sexo aparente, ou seja, à identidade sexual, formada também por componentes psicossociais", acrescentando "Em última análise, afirmar a dignidade humana significa para cada um manifestar sua verdadeira identidade, o que inclui o reconhecimento da real identidade sexual, em respeito à pessoa humana como valor absoluto" (STJ, REsp 1.008.398 - SP (2007/0273360-5), Rel Min Nancy Andrigui, DJE 18/11/2009, p. 7 e 12).

Em outro precedente, o Relator, ao reformar acórdão que extinguira a ação por impossibilidade jurídica do pedido, reconheceu a viabilidade de alteração do sexo no registro em proteção da "identidade pessoal" do demandante: "5. Não entender juridicamente possível o pedido formulado na exordial significa postergar o exercício do direito à identidade pessoal e subtrair do indivíduo a prerrogativa de adequar o registro do sexo à sua nova condição física, impedindo, assim, a sua integração na sociedade" (STJ, REsp 737.993 - MG (2005/0048606-4), Rel Min João Otávio de Noronha, j. 10/11/2009). 
O Tribunal de Justiça do Estado de São Paulo igualmente vem admitindo a alteração do sexo no registro civil, no reconhecimento efetivo da identidade sexual, valendo conferir algumas Ementas:

"Retificação de registro civil. Cirurgia de redesignação sexual Alteração do registro de gênero, de masculino para feminino. Requerente que fez prova da cirurgia de redesignação sexual. Constrangimento desnecessário ao requerente a manutenção de sexo masculino no registro, após a alteração de prenome. Princípio da dignidade humana. Ação procedente. Recurso improvido" (Apelação Cível no $0015957-$ 43.2010.8.26.0664, 4 ${ }^{\mathrm{a}}$ Câmara de Direito Privado, Rel. Francisco Loureiro, j. 04/08/2011);

"Registro civil. Alteração de nome e sexo do requerente em virtude de sua condição de transexual. Admissibilidade. Desnecessidade de remessa de certidões complementares da justiça federal. Ausência de coincidência dos dados identificadores complementares dos réus nos feitos apontados na certidão. Caso em que inexiste qualquer prejuízo a terceiro. Alteração do sexo que se mostra de rigor ante as condições de gênero peculiares ao requerente. Acerto da determinação para a averbação da informação relativa à decisão judicial no assento de nascimento. Medida suficiente que alia a necessária preservação do interesse de terceiros ao resguardo do autor às eventuais situações de potencial constrangimento. Procedência da demanda mantida. Recurso de apelação improvido" (Apelação Cível no 0013923-23.2008.8.26.0161, 6 6 Câmara de Direito Privado, Rel. Vito Guglielmi, j. 28/04/2011); e

"Retificação de registro civil - assento de nascimento transexual - alteração na indicação do sexo - deferimento - necessidade da cirurgia para a mudança de sexo reconhecida por acompanhamento médico multidiscipunar concordância do Estado com a cirurgia que não se compatibiliza com a manutenção do estado sexual originalmente inserto na certidão de nascimento - negativa ao portador de disforia do gênero do direito à adequação do sexo morfológico e psicológico e a consequente redesignaçâo do estado sexual e do prenome no assento de nascimento que acaba por afrontar a lei fundamental - inexistência de interesse genérico de uma sociedade democrática em impedir a integração do transexual - alteração que busca obter efetividade aos comandos previstos nos arts. 1o, III, e 3o, IV, da Constituição Federal - recurso do ministério público negado, provido o do autor para o fim de acolher integralmente o pedido inicial, determinando a retificação de seu assento de nascimento não só no que diz respeito ao nome, mas também no que concerne ao sexo relatório" (Apelação Cível n 209.101-4/000, 1ª Câmara de Direito Privado, Rel. Elliot Akel, j. 09/04/2002). 
A análise da jurisprudência revela que o Poder Judiciário tem se inclinado a admitir a pretensão de alteração do nome e do sexo, na hipótese de transexual submetido à cirurgia de transgenitalização, com vistas a não impedir sua integração à sociedade (STJ-REsp 678.993-RS (2004/0098083-5), Rel. Min Carlos Alberto Menezes Direito, j. 22/03/2007).

Em relação à mudança de sexo do transexual não operado, temse conhecimento de uma decisão em que foi enfrentada a questão favoravelmente, embora o voto tenha ficado vencido. A Relatora Maria Berenice Dias decidia pela possibilidade da alteração, admitindo a retificação do sexo do transexual que mantinha seu órgão sexual não alterado, mas que há tempos ingeria hormônios, havia realizado cirurgia para tornar a voz mais aguda, usava vestimentas femininas diariamente e apresentava-se como mulher. Após analisar a prova, asseverou: "Diante dessas circunstâncias, o fato de o apelante ainda não ter se sumetido à cirurgia para alteração do sexo não pode constituir óbice ao deferimento do pedido em comento" (TJ/RS, Apelação Cível no 70013909874/2005, 7ª Câmara Cível, j. 05/04/2006, p. 5). Prevaleceu o entendimento do Revisor, desembargador Luiz Felipe Brasil Santos, ao ponderar: "enquanto não extirpados os órgãos sexuais masculinos do requerente este estará, em tese, apto a reproduzir como homem. Logo, deferir-se a modificação do registro, desde já, para que conste que é mulher, poderá ensejar situação verdadeiramente kafkiana, pois, podendo potencialmente vir a fecundar uma mulher, será pai. E teríamos então uma mulher pai!" (acórdão citado, p. 10/11).

O argumento é sensível e desperta perplexidade, não se pretendendo oferecer uma resposta que encerre a questão. Apenas que, para trazer novo elemento à discussão, a eventual ocorrência do fato aventado pelo Relator para negar a mudança de sexo ao transexual não operado não seria uma novidade, já existindo situações em que se anotam dois pais ou duas mães no assento de nascimento, no caso do deferimento de adoção por homossexuais.

No mais, a pretensão ao reconhecimento da identidade sexual sem cirurgia é uma realidade posta perante o Poder Judiciário, existindo ação pendente.

Em julho de 2009, a ABGLT - Associação Brasileira de Gays, Lésbicas, Bissexuais, Travestis e Transexuais, em parceria com a ANTRA - Articulação Nacional de Travestis e Transexuais, encaminhou ofício à Procuradoria Geral da República para que fosse garantido o "reconhecimento e uso do nome social de Travestis e 
Transexuais, sendo possível a mudança de prenome e sexo no registro civil de nascimento, no caso de já haver sido feita a cirurgia de transgenitalização ou não" "743 (sublinhei).

Provocado pela postulação, o Ministério Público Federal ajuizou uma Ação Direta de Inconstitucionalidade - ADI 4275-1/600, cujo pedido visa "a que seja proferida decisão de interpretação conforme a Constituição do art. 58 da Lei 6.015/73, na redação que lhe foi conferida pela Lei 9.708/98, reconhecendo o direito dos transexuais, que assim o desejarem, à substituição de prenome e sexo no registro civil, independentemente da cirurgia de transgenitalização". A ação encontra-se em tramitação, recentemente tendo sido admitida a intervenção do IBDFAM - Instituto Brasileiro de Direito de Família, como terceiro interessado. ${ }^{744}$

A pretensão envolve, assim, o reconhecimento do direito à identidade de gênero independentemente da anatomia do sexo, afinada com a concepção social de gênero desenvolvida no item próprio, segundo a qual o gênero se refere mais ao papel social desempenhado pela pessoa do que à intimidade do órgão sexual.

Indica, outrossim, o fortalecimento do trato da transexualidade sob o enfoque da identidade e dos direitos humanos, que se revela na demanda de alteração do gênero no registro, ainda que a pessoa não tenha se submetido à cirurgia de mudança de sexo. Percebe-se, assim, o deslocamento do debate sobre a identidade de gênero para além da licitude da cirurgia e dos limites do direito ao corpo, inserindo-o na temática dos direitos humanos sob a perspectiva da igualdade de direitos, não obstante o reconhecimento da diferença.

\section{0) Reflexos do direito à identidade de gênero ou sexual}

Lembra Javier Perona que o gênero é critério para a organização e regulamentação de vários aspectos da vida social, como o serviço militar, o casamento, o recolhimento em presídio, o sistema previdenciário e as relações de trabalho, além de trazer consequências para as relações familiares, como na hipótese de transexual casado ou com filhos anteriores. ${ }^{745}$

\footnotetext{
${ }^{743}$ STF, ADI 4275-1/600, p. 27.

${ }^{744}$ Despacho publicado em 22/06/2011. Disponível na consulta do extrato da ADI 4275, Relator Ministro Marco Aurélio, no endereço: www.stf.jus.br/portal/processo/verProcessoAndamento.asp, último acesso em 24/11/2011.

${ }^{745}$ PERONA, Javier López-Galiacho. La problemática jurídica de la transexualidad, cit., p. 126.
} 
Nessa esteira, a alteração do gênero de alguém afeta não só a própria pessoa, mas também todos aqueles que com ela estabeleceram relação jurídica em algum momento da vida.

Anota Hottois que os terceiros envolvidos na questão da mudança de identidade do transexual são: "os próximos (cônjuges, pais, filhos, etc.) ligados ao transexual segundo seu sexo e estado civil primitivos; são também as pessoas com as quais o transexual manteve um relacionamento significativo, contratual ou não; são, finalmente, a Sociedade em geral e sua Ordem simbólica, que postulam tradicionalmente que o indivíduo conserve durante toda a vida o sexo com que nasceu". ${ }^{746}$

Nesse contexto, essencial seria a promulgação de lei que regulamentasse os efeitos da transexualidade, na consideração de que as dificuldades suscitadas pela mudança de sexo, ainda que profundas, não parecem incontornáveis.

Tome-se o exemplo das questões previdenciárias.

Elimar Szaniawski entende que a redesignação civil do sexo não causará empecilho ao transexual, bastando-lhe comprovar a alteração para receber seu benefício de acordo com o novo sexo. ${ }^{747}$ À vista da diferença de prazos para a aposentadoria do homem e da mulher, acrescenta Luiz Alberto David Araújo a necessidade de proceder ao cálculo proporcional do tempo de serviço antes e depois da operação, de acordo com o regime legal próprio de cada sexo. ${ }^{748}$

As competições esportivas igualmente podem ser lembradas.

A fim de evitar a discriminação, sustenta Javier Perona que o transexual operado possa competir de acordo com seu novo sexo, ainda que admita haver uma vantagem biológica no caso da mulher transexual. ${ }^{749}$ A lei inglesa, de 2004, por seu turno, expressamente disciplinou a proibição ou restrição de pessoas que tenham mudado de sexo em competições esportivas, para assegurar uma competição justa e segura, excluindo a caracterização desta limitação como conduta discriminatória (Gender Recognition Act, 2004. (...) 19. Sport (1), (2), (3), (4) e (5)).

Interessante é a solução proposta por David Araújo, ao salientar que, para o esporte, o conceito de sexo não é mais estritamente biológico, ganhando relevância o índice hormonal. Pondera que há inclusive pessoas nascidas mulheres, recusadas em competições femininas diante dos resultados dos testes hormonais. A partir

\footnotetext{
${ }^{746}$ HOTTOIS, Gilbert. Verbete transexualismo, na Enciclopédia de bioética, p. 653.

${ }^{747}$ Limites e possibilidades do direito de redesignação do estado sexual, cit., p. 159.

${ }^{748}$ A proteção constitucional do transexual, cit. , p. 141/142.

${ }^{749}$ PERONA, Javier López-Galiacho. La problemática jurídica de la transexualidad, cit., p. 362.
} 
daí, entende que a participação do transexual na categoria do novo sexo dependeria menos do fato de ter ocorrido uma mudança e mais do índice hormonal encontrado, acrescentando que o avanço da Medicina Esportiva permite alcançar resultados bastante precisos, evitando injustiças. ${ }^{750}$

Feitas essas breves considerações, cabe agora enfrentar com mais vagar os três temas jurídicos que talvez suscitem as maiores dificuldades: o registro, o casamento e a filiação.

\section{0.a) O Registro Civil: conteúdo da anotação, forma, efeitos} temporais e publicidade

O Registro Civil, por conter presunção de veracidade e destinarse a dar publicidade ao estado da pessoa, atua como instrumento de reconhecimento da identidade no meio social, tratando-se de instituto relevante para a promoção de direitos do transexual.

Assim, quer se exija, quer não, a operação como condição para a mudança, o reconhecimento jurídico da identidade de gênero e a anotação do novo nome e sexo no registro trazem implicações sobre as quais é relevante refletir.

Na Idade Média, cabia à Igreja registrar os principais momentos da vida civil da pessoa: o nascimento, o casamento e o óbito. Já no século XIX, constatada a insuficiência dessa forma de anotação para o controle dos atos, quer em razão da predominância do batismo sobre o nascimento, quer em virtude do aumento de filiados a outras crenças, institui-se o registro pela Lei $1.144 / 1861 .^{751}$ O Decreto 9.886/1888 organizou o Registro Civil, atualmente regulado pela Lei n 6015/1973.

Por meio do registro, confere-se publicidade aos fatos jurídicos de interesse da pessoa e da sociedade, sendo-lhe reconhecida a função de "dar autenticidade, segurança e eficácia aos fatos jurídicos de maior relevância para a vida e os interesses dos sujeitos de direito". ${ }^{752}$ Sua prova não é absoluta, podendo ser anulado por erro ou falsidade. ${ }^{753}$

Daí a importância das certidões de Registro Civil, como meio de prova do estado da pessoa, como confirmação jurídica de que ela é quem aparenta ser, de que há harmonia entre sua identidade social e jurídica.

\footnotetext{
${ }^{750}$ A proteção constitucional do transexual, cit., p. 142/143.

${ }^{751}$ PEREIRA, Caio Mário. Instituições de Direito Civil, cit., p. 236/237.

${ }^{752}$ AMARAL, Francisco, Direito Civil. Introdução, cit., p. 279.

${ }^{753}$ PEREIRA, Caio Mário. Instituições de Direito Civil, cit., p. 237.
} 
Pondera Fábio Siebeneichler de Andrade que a disciplina quanto à alteração de sexo e demais repercussões no registro civil, expressa no art. 71, do Código Civil do Quebec, poderia ter servido de inspiração ao legislador brasileiro, entendendo injustificável que o Código Civil de 2002 não a tenha regulado de forma expressa, na concretização da dignidade enunciada na Constituição. ${ }^{754}$

A inexistência de lei, contudo, não dispensa refletir sobre o conteúdo da anotação, a forma, os efeitos temporais e a publicidade do registro, ainda que sem a pretensão de esgotamento.

\section{0.a.1) Conteúdo da anotação}

Antes de ingressar especificamente na questão relativa à forma do registro, cabe lembrar que a mudança de sexo nem sempre foi pensada em termos da oposição masculino/feminino e inicialmente se voltava à anotação da pessoa como transexual.

Em sentença referida por Benedito Silvério Ribeiro, o Magistrado Henrique Nelson Calandra, em 28/08/1992, reconheceu a mudança de nome e sexo de transexual operado na Suíça, com base nas características biológicas e psíquicas ostentadas pelo autor, que não mais se adequavam ao sexo original. $\mathrm{Na}$ época, a sentença transitada em julgado, contra a qual não foi interposto recurso, decidiu pela anotação "transexual" no campo destinado ao sexo, sob a seguinte fundamentação: "Creio que o mais acertado será, diante da omissão legislativa, fazer constar o que realmente o autor é à luz da ciência atual, ou seja, transexual. Embora possa até chocar, esta é a realidade do autor, não sendo possível diante da omissão do legislador lhe negar amparo, mantendo-o numa condição à margem do direito, ficando a Justiça petrificada e cega diante da sua situação, que embora possa ser considerada por alguns afrontosa ao que a sociedade considera normal, não pode ser ignorada". 755

Em que pese o avanço da decisão para a época, bem como o sentido de reconhecimento que expressa, praticamente não há divergência atual, na doutrina e jurisprudência, de que a melhor forma de promoção da igualdade pelo

\footnotetext{
${ }^{754}$ Considerações sobre a Tutela dos Direitos da Personalidade no Código Civil de 2002. in O novo Código Civil e a Constituição. Org. Ingo Wolfgang Sarlet, p. 111/112.

${ }^{755}$ RIBEIRO. Benedito Silvério. Análise de Casos que Implicam Alterações no Registro Civil. in Serviços Notariais e de Registro. Teses Apresentadas no Primeiro Simpósio Nacional de Serviços Notariais e Registrais de São Paulo, de 11 a 13 de setembro de 1996. Editado por Associação dos Notários e Registradores do Estado de São Paulo e Associação dos Serventuários de Justiça do Estado de São Paulo, p. 142.
} 
reconhecimento jurídico é aquela apta a inserir a pessoa como alguém pertencente ao sexo oposto, reconhecendo-a como "feminino" ou "masculino", a partir do gênero de identificação.

Maria de Fátima Freire de Sá e Bruno Torquato de Oliveira Naves não são favoráveis à criação de um terceiro sexo, sustentando que devem ser alterados judicialmente o prenome e o gênero do transexual, após a cirurgia de adequação, sob pena de discriminação ou segregação. São contrários a qualquer tipo de anotação, como "operado" ou transexual, entendendo que violaria o direito à intimidade das pessoas. ${ }^{756}$

Nessa medida, não bastaria a alteração do registro para constar "transexual", fazendo-se necessário o reconhecimento da identidade de gênero da pessoa com base em sua aparência física e em seu sexo psicológico.

Ao que parece, o que caracteriza a transexualidade é exatamente a identificação com o sexo oposto, inexistindo uma postulação de ser reconhecido como transexual, mas, sim, como alguém do sexo ao qual a pessoa se sente e acredita pertencer. Por isso, negar o reconhecimento mediante a atribuição de um terceiro sexo acabaria por acentuar a discriminação e a desigualdade de tratamento que se pretende combater.

Como pondera Luiz Alberto David Araújo, manter a inscrição "transexual" implica marcar a pessoa como anormal para sempre, em franca violação da igualdade. Nas palavras do professor: “O grilhão amarrado ao pé do transexual será sempre exibido, como pena perpétua, impedindo sua integração social". 757

\section{0.a.2) Forma para a mudança do prenome e do sexo no}

\section{Registro Civil}

As alterações do nome e do sexo, envolvendo mudança de estado, devem ser averbadas no registro civil, nos moldes dos artigos $9^{\circ}$ e 10 , do Código Civil brasileiro, do que resulta a importância do registro para a proteção dos direitos dos transexuais.

Na Espanha e Portugal, os procedimentos para as respectivas mudanças são administrativos (Lei 3/2007, art. 3, e Lei 7/2011, arts 1 e 2, respectivamente), iniciados diretamente no Cartório de Registro Civil.

\footnotetext{
${ }^{756}$ Transexualismo. in Manual de Biodireito, cit., p. 263 e p. 266.

${ }^{757}$ A proteção constitucional do transexual, cit., p. 135.
} 
No Brasil, na ausência de lei, faz-se necessário o ajuizamento de ação. Em que pese a Lei dos Registros Públicos prever a possibilidade de jurisdição voluntária, exige-se o procedimento contencioso na hipótese de mudança de sexo, ação de estado envolvendo direitos de terceiros, dada a extensão de seus efeitos jurídicos. ${ }^{758}$

O pedido deve ser instruído com as certidões dos distribuidores forenses da Justiça Estadual, Federal, Trabalhista, Militar e Eleitoral, além das certidões de protesto e atestado de antecedentes criminais, comunicando-se eventual retificação em caso de informação positiva, sem custos para o interessado. ${ }^{759}$

A competência é da Vara de Família, por envolver uma mudança de estado relativamente ao sexo, já tendo sido anulada sentença proferida pela Vara de Registros Públicos. ${ }^{760}$ A natureza da sentença é constitutiva. Em caso de procedência, caberá ao juízo comunicar a retificação aos órgãos competentes, como a Receita Federal, o Instituto de Identificação Civil e Circunscrição Militar. ${ }^{761}$

A forma para promover alterações do nome e sexo em registro já existente é a averbação, nos moldes do art. 10, do Código Civil. Trata-se de ato de caráter acessório, ${ }^{762}$ vinculado ao registro anterior, modificado pela averbação. Nesses termos, a averbação é feita à margem do registro original do livro de nascimento.

A lavratura de um novo registro não é necessária, até porque não há outro nascimento que justificasse um novo assento, mas apenas o reconhecimento da identidade sexual assumida no processo do desenvolvimento da personalidade de pessoa já existente.

A averbação não se confunde com anotação, esta última consistente em remissões recíprocas dos registros e averbações, feitos pelo oficial em seus livros (LRP, art. 106). Enquanto a averbação modifica o registro existente, a anotação destina-se a "recordar, para facilidade de buscas, os registros recíprocos". ${ }^{763}$ Assim, a

\footnotetext{
${ }^{758}$ MOTA, Júlia Cláudia Rodrigues da Cunha. O registro civil de pessoas naturais e o transexual. In Revista Forense nº 411 - 2010. Rio de Janeiro: Forense, 2010, p. 144.

${ }^{759}$ Idem, mesma página.

${ }^{760}$ RIBEIRO. Benedito Silvério. Análise de Casos que Implicam Alterações no Registro Civil. in Serviços Notariais e de Registro. Teses Apresentadas no Primeiro Simpósio Nacional de Serviços Notariais e Registrais de São Paulo, de 11 a 13 de setembro de 1996. Editado por Associação dos Notários e Registradores do Estado de São Paulo e Associação dos Serventuários de Justiça do Estado de São Paulo., p. 138.

${ }^{761}$ MOTA, Júlia Cláudia Rodrigues da Cunha. O registro civil de pessoas naturais e o transexual, cit., p. 154.

762 TEPEDINO, Gustavo; BARBOZA, Heloísa Helena; e MORAES, Maria Celina Bodin de. Código Civil Interpretado conforme a Constituição da República, p. 28

${ }^{763}$ CENEVIVA, Walter. Lei dos Registros Públicos Comentada. São Paulo: Saraiva, 1988, p. 219.
} 
utilização do termo averbação para tratar da mudança de nome e sexo do transexual afigura-se tecnicamente mais adequada.

Para a mudança no registro de imóveis do transexual proprietário, a fim de que passe a constar sua nova qualificação, nos termos do art. 167, II, 5, da Lei $n^{\circ} 6.015 / 73$, será suficiente a apresentação de certidão de objeto e pé contendo o nome e sexo anteriores para a averbação na matrícula do imóvel. ${ }^{764}$

\section{0.a.3) Efeitos temporais da averbação da mudança de} prenome e sexo no assento de nascimento: irretroatividade

Em relação aos efeitos temporais da averbação da mudança, a melhor solução é aquela que preserva válidos os efeitos do registro até a data do reconhecimento da identidade de gênero, mantendo uma perfeita paridade temporal entre a informação do registro e a identidade da pessoa.

A irretroatividade da mudança consta expressamente nas leis italiana, inglesa, espanhola, belga e portuguesa, reconhecendo-se a pessoa tanto sob o gênero natural quanto pela identidade sexual, a depender de como estava a inscrição no registro na data do fato. Assim, permanecem intactos os atos praticados até a data da mudança, admitindo-se a pessoa como pertencente ao outro sexo a partir da data da averbação da identidade sexual, com efeitos para o futuro (art. $4^{\circ}$, da Lei Italiana 164/1982; art. 9.2, do Recognition Gender Act do Reino Unido; art. 5 , da Lei Espanhola n ${ }^{\circ}$ 3/2007; art. $2^{\circ}$, $\S 4^{\circ}$, da Lei Belga ${ }^{\circ} 10 / 55$, de 2007; e art. $5^{\circ}$, da Lei Portuguesa 7/2011).

Acredita-se que anular o registro original ou admitir efeitos $e x$ tunc à mudança contribuiria para a insegurança jurídica, comprometendo a ordem pública, na medida em que desconsideraria a realidade dos vínculos estabelecidos até então, com base no outro sexo.

E, admitida a identidade sexual como algo construído pela pessoa, no exercício de sua liberdade e autonomia, no curso do desenvolvimento de sua personalidade desde o nascimento, não se pode negar a vida pretérita ou a veracidade dos fatos anteriores à consolidação da identidade de gênero.

Esse entendimento, sustenta-se, preserva a intimidade e a dignidade da pessoa transexual, em respeito à sua história passada e às relações jurídicas contraídas antes de obter sua identidade sexual.

\footnotetext{
${ }^{764}$ MOTA, Júlia Cláudia Rodrigues da Cunha. O registro civil de pessoas naturais e o transexual, cit., p.
} 149. 


\section{0.a.4) A publicidade da averbação da mudança de prenome} e sexo no assento de nascimento

Outra questão relevante refere-se à publicidade da averbação. $\mathrm{O}$ tema é complexo e demanda maior aprofundamento.

O registro assegura publicidade aos atos jurídicos. Daí a regra de que devem estar permanentemente abertos ao conhecimento de todos, com poucas exceções, do que decorre a obrigação do fornecimento de certidões pelo Oficial, ${ }^{765}$ nos termos do art. 16, da Lei $n^{\circ}$ 6015/73. Ressalva o art. 18 hipóteses de exceção, tratando-se de situações em que a expedição da certidão dependerá, excepcionalmente, de decisão judicial, assegurando-se o sigilo do registro, a fim de preservar a intimidade e a privacidade das pessoas. $^{766}$.

O art. 21, da mesma lei, estabelece a obrigação de o Oficial mencionar as alterações posteriores efetuadas no registro, por ocasião do fornecimento de certidões, sob pena de sua responsabilidade civil e penal.

A partir daí, discutem a doutrina e a jurisprudência sobre a divulgação do nome e sexo originais da pessoa transexual nas certidões de nascimento expedidas após a averbação da respectiva mudança.

São três as exceções à publicidade previstas na lei, nenhuma delas relativa à situação do transexual, ainda não regulamentada pelo legislador brasileiro.

A primeira hipótese consta do art. 45, superado pelo art. $227, \S$ $6^{\circ}$, da Constituição Federal, que vedou distinção entre os filhos sob o aspecto da filiação. A lei previa situação em que a certidão seria fornecida, sem o teor da averbação relativa à legitimação do filho em consequência do casamento dos pais. Vale anotar, então, a existência de previsão na lei de registros públicos da lavratura de certidão omissa em relação à integralidade do registro, em proteção à intimidade da pessoa do filho.

A segunda exceção legal à publicidade do registro de nascimento refere-se à alteração de nome provocada por fundada coação ou ameaça decorrente de colaboração com apuração de crime, hipótese em que não haverá a averbação do nome alterado (art. $57, \S 7^{\circ}$ ).

Já a terceira e última hipótese refere-se à adoção, na qual se lavra um novo registro em nome dos pais adotivos, com o cancelamento do assento

\footnotetext{
${ }^{765}$ CENEVIVA, Walter. Lei dos Registros Públicos Comentada, cit., p. 27 e 28.

766 SWENSSON, Walter Cruz. NETO, Renato Swensson. SWENSSON, Alessandra Seino Granja. Lei de Registros Públicos Anotada. 4ª ed. São Paulo: Juarez de Oliveira, 2006, p. 52.
} 
original (art. 96), não podendo o oficial fornecer certidão do mandado arquivado, "a não ser por determinação judicial e em segredo de justiça, para salvaguarda de direitos" (Lei n 6.015/73, art. 95, parágrafo único, parte final). A matéria atualmente é regulada pelo Estatuto da Criança e do Adolescente, que manteve a mesma disciplina quanto ao cancelamento do registro original, mas vedou a possibilidade do fornecimento de certidão, determinando que nenhuma observação sobre a origem do ato conste nas certidões do registro (ECA, art. 47, caput e parágrafos). Nesse caso, a verdade do ato desloca-se do registro para o processo judicial, que passa a ser o único documento a conter os antecedentes da filiação obtida pela adoção, garantindo-se o arquivamento do processo para consulta a qualquer tempo pelo adotado (ECA, art. 47, $\S 8^{\circ}$, e art. 48).

Diante de tal conjunto normativo, a que se recorre por analogia à falta de lei específica, a posição doutrinária intermediária, admitindo a divulgação da mudança de nome e sexo averbada na margem do registro, mediante requerimento de interessado e por ordem judicial, parece prevalecer.

$\mathrm{Na}$ ponderação de Elimar Szaniawski, é preciso encontrar um meio-termo entre o direito à identidade sexual e a publicidade da redesignação, "mediante certo sigilo e discrição, mas sem se impedir, totalmente, a terceiros de virem a conhecer, quando necessário, a transformação sexual sofrida artificialmente, por seu futuro cônjuge ou companheiro". ${ }^{767}$

Maria Helena Diniz, com base no direito da pessoa transexual ao esquecimento do estado anterior que causou tanto sofrimento, afirma que o mandado judicial de retificação deve determinar a averbação da mudança de prenome e sexo à margem do registro, bem como o seu arquivamento, aplicando analogamente a antiga redação do ECA, art. $47, \S 1^{\circ}$. Desse modo, entende que novas certidões não devem fazer menção à natureza das retificações procedidas, consignando apenas que o referido assento foi retificado por ordem judicial, em segredo de justiça, somente sendo possível o fornecimento de certidão de inteiro teor a critério da autoridade judiciária (analogia com a então disciplina do ECA, art. $\left.47, \S 5^{\circ}\right) .{ }^{768}$

\footnotetext{
${ }^{767}$ Limites e possibilidades do direito de redesignação do estado sexual, cit., p. 191.

${ }^{768}$ DINIZ, Maria Helena. O estado atual do biodireito, cit., p. 265/267.
} 
Sustenta Tereza Rodrigues Vieira que a mudança de sexo por decisão judicial fique averbada no livro de Registro de Nascimento, a fim de que somente seja conhecida por terceiros se for requerida uma certidão de inteiro teor. ${ }^{769}$

Entende Reinaldo Velloso dos Santos que a certidão não consignará o sexo e nome original no registro, mas tão somente o atual, com a observação do parágrafo único, do art. 21, da Lei n ${ }^{\circ} 6.015 .^{770}$

Propõe Luiz Alberto David Araújo, “o deferimento da alteração do sexo do transexual operado, sem qualquer menção a seu estado anterior nem a sua condição de transexual", ${ }^{771}$ o que parece traduzir posição minoritária.

A jurisprudência inclina-se no sentido de averbar a mudança de nome e sexo no assento de nascimento original, recusando a lavratura de um novo assento:

“APELAÇÃO - Retificação de registro civil - Transexual que se submeteu à cirurgia de adequação ao sexo feminino - Obediência ao princípio da dignidade da pessoa humana - Harmonização dos direitos e garantias fundamentais com a segurança jurídica e a verdade registrária - Modificação de nome e sexo que, no entanto devem ser processadas pela via da averbação, para que se preserve a continuidade do registro civil e os direitos de terceiro - Recurso provido" (Apelação Cível no 994.08.045777-8, $3^{\text {a }}$ Câmara de Direito de Privado, Rel Egidio Giacoia, j. 23/02/2010).

Na sentença proferida em ação ajuizada por Roberta Close foi autorizada a mudança de seu nome de Luís Roberto Gambine Moreira para Roberta Gambine Moreira, determinando que fosse incluída no registro civil a anotação de "operada". Em segundo grau, a sentença foi reformada, entendendo-se pela impossibilidade da alteração do nome em face da inviabilidade de modificação dos órgãos sexuais internos. Em 2001, Roberta Close ajuizou nova ação, sendo reconhecida mulher por sentença datada de 04/03/2005. O Ministério Público, desta vez, opinou favoravelmente, em procedimento de jurisdição voluntária, não sendo interposto qualquer recurso. A sentença transitada em julgado trouxe a seguinte ressalva: "Determino a fim de

\footnotetext{
${ }^{769}$ A bioética e o direito à adequação de sexo do transexual. in Bioética e Sexualidade. VIEIRA, Tereza (coord). São Paulo: Jurídica Brasileira, 2004, p. 118 (107-122).

${ }^{770}$ SANTOS, Reinaldo Velloso dos. Registro Civil das Pessoas Naturais. Porto Alegre: Fabris, 2006, p. 182.

${ }^{771}$ A proteção constitucional do transexual, cit., p. 141.
} 
resguardar possíveis interesses de terceiros que conste à margem do registro a anotação quanto ao fato de que a alteração de nome e de Estado, deu-se por força de sentença" ${ }^{772}$

Em relação à publicidade do registro que se concretiza no conteúdo das certidões, há certa divergência nos Tribunais, ora vedando-se qualquer anotação, ora determinando-se a consignação de que existem alterações realizadas por ordem judicial, de todo modo restringindo a divulgação de seu conteúdo à ordem judicial. Cabe trazer algumas dessas decisões, a título de ilustração.

No Recurso Especial n ${ }^{\circ}$ 1.008.398-SP, julgado em 15/10/2009, de relatoria da Ministra Nancy Andrighi, decidiu a Turma "que das certidões do registro público competente não conste que a referida alteração é oriunda de decisão judicial, tampouco que ocorreu por motivo de redesignação sexual do transexual". 773

Em acórdão da lavra do Ministro João Otávio de Noronha, ressalvou o Relator, após determinar a averbação das retificações de nome e sexo na margem do assento de nascimento: "Todavia, tal averbação deve constar apenas do livro de registros, não devendo constar nas certidões do registro público competente nenhuma referência de que a aludida alteração é oriunda de decisão judicial, tampouco que ocorreu por motivo de cirurgia de mudança de sexo, sob pena de manter a exposição do indivíduo a situações constrangedoras e discriminatórias" (REsp 737.993 - MG, j. 10/11/2009, p. 9, do acórdão). ${ }^{774}$

$\mathrm{Na}$ jurisprudência paulista, encontram-se os seguintes

precedentes:

"Registro civil. Alteração de nome e sexo do requerente em virtude de sua condição de transexual. Admissibilidade. Sentença, contudo, que determina a supressão da observação, na averbação, da origem da alteração do assento em decisão judicial. Impossibilidade. Garantia de direitos de terceiros. Precedentes da corte e deste relator. Necessidade de manutenção do vínculo entre a pessoa que juridicamente existe e aquela que formalmente existiu. Inexistência no caso, ademais, de situação de constrangimento. Averbação que terá lugar apenas no assento de nascimento. Decisão

\footnotetext{
772 In Vieira, Tereza Rodrigues. Reconhecimento do direito a adequação do nome e sexo de "Roberta Close". Reflexiones Bioéticas (Asociación Argentina de Bioética), Mar del Plata. Disponível em: http//www.aabioetica.org/mj1.htm).

773 Informativo de Jurisprudência do Superior Tribunal de Justiça, n. 0411. Período: 12 a 16 de outubro de 2009.

${ }^{774}$ Informativo de Jurisprudência do Superior Tribunal de Justiça, n. 0415. Período: 09 a 13 de novembro de 2009.
} 
alterada. Recurso provido" (Apelação Cível nº 0007869-83.2009.8.26.0168, 6 Câmara de Direito Privado, Rel Vito Guglielmi, j. 28/04/2011).

Nas palavras do relator:

"Note-se que o que se comunga é a orientação de que a averbação não necessite ser esclarecedora de que se trata de mudança de nome e sexo, de modo que só quem tenha efetivo interesse em saber qual o seu motivo, possa pedir certidão específica do registro. Omiti-la ou limitá-la à requisição judicial é permitir, em tese, que terceiros sejam induzidos a erro ao manter relacionamento jurídico com o requerente, e, sobretudo, afastar qualquer liame entre a pessoa que hoje existe e a que existiu (juridicamente, ressalte-se)".

"Na medida em que não se faz constar qualquer averbação se exclui qualquer vinculo entre a vida atual e a vida passada. Ainda que não se conheça, pelas certidões existentes, algum impeditivo à alteração, o certo é que o recorrente viveu com seu nome e sexo anterior e pode (e se supõe que deva) ser sujeito de direitos e obrigações. A falta de liame entre um e outro excluiu por completo a vida com o nome e sexo anterior" (Acórdão citado, p. 05).

E conclui: "Por fim, a certidão de nascimento, via de regra, é documento exigido em limitadíssimas hipóteses, de modo que o constrangimento no dia a dia da vida se mostra afastado com a utilização dos documentos de identidade e habilitação, por exemplo. Logo, a circunstância de ser produto de averbação decorrente de decisão judicial a alteração do nome e sexo deve permanecer, e bem a possibilidade de que, disso, certidão se extraia. Daí o provimento do recurso de apelação do Ministério Público" (fls 05, do mesmo Acórdão).

A legislação alienígena orienta-se no sentido da não publicidade da mudança de nome e sexo, condicionando-a à requisição da autoridade ou ao pedido do próprio interessado.

Esse o teor da lei espanhola (art 7), ${ }^{775}$ e da lei portuguesa, 7/2011, cujo art. $5^{\circ}$, ao alterar o art. $214^{\circ}$ do Código de Registo Português, determinou que as certidões integrais do assento em que averbada a mudança de nome e sexo só sejam fornecidas a requerimento do próprio, de seus herdeiros, ou de autoridades judiciais e policiais para investigação ou instrução criminal. A lei italiana determina que, após a

\footnotetext{
${ }^{775}$ Ley 3/2007: "Articulo 7. Publicidad. No se dará publicidad sin autorización especial de la rectificación registral de la mención relativa al sexo de la persona”.
} 
mudança, a certidão seja expedida apenas com a indicação do novo nome e sexo da pessoa (art. $5^{\circ}$, da Lei italiana $\left.n^{\mathrm{o}} 164 / 1982\right){ }^{776}$

Diante de tantos elementos, urge indagar sobre a melhor forma de harmonizar a dignidade do transexual com a publicidade dos registros perante o ordenamento brasileiro, especificamente quanto ao conteúdo das certidões extraídas do assento de nascimento modificado por averbação.

A questão igualmente poderia ser formulada em outros termos, sobre a aplicação do art. 21, caput e par. único, da Lei de Registros Públicos, à hipótese de mudança de nome e sexo decorrente da transexualidade. Ou seja, se a averbação de tal mudança deveria ser pública, ficar absolutamente sigilosa, ou se seria admitida tão somente a anotação de que "a presente certidão envolve elementos de averbação à margem do termo", nas certidões expedidas após a averbação.

Desde logo, pode-se afirmar que a publicidade irrestrita da mudança não se coaduna com a ótica dos direitos humanos, voltada à proteção da pessoa transexual contra a violência e a discriminação. De fato, permitir a divulgação indiscriminada da mudança acabaria por prorrogar um constrangimento incompatível com o sistema protetivo dos direitos humanos e com o princípio da dignidade da pessoa que o inspira. Significaria, ademais, a propagação de fatos particulares e íntimos, que não interessam ao público em geral, na violação da vida privada da pessoa.

Como consignado pelo Desembargador Maurício Vidigal, na Apelação Cível n. 514.688-4/6, julgada pela $10^{a}$ Câmara de Direito Privado do TJ/SP, em 31/03/2009: "Observe-se que a verdade tem valor inestimável, mas que, muitas vezes, em defesa dos interesses sociais, ela não pode ser revelada a todos. Se não existissem preconceitos, ela sempre poderia ser divulgada. Como infelizmente eles são inevitáveis no mundo atual, esconde-se parcialmente a verdade para que prevaleça a harmonia social e se combata o comportamento preconceituoso".

Por outro lado, a absoluta omissão quanto à existência da averbação, embora à primeira vista pareça sedutora, não se reveste da veracidade necessária para sustentar sua defesa. De fato, na pressuposição de que a identidade de gênero não é adquirida no momento do nascimento, mas, sim, o resultado do processo de individualização da pessoa, forçoso reconhecer o transcurso de uma parcela da vida sob a

\footnotetext{
776 Art. 5". "Le attestazioni di stato civile riferite a persona della quale sia stata giudizialmente rettificata l'attribuzione di sesso sono rilasciate con la sola indicazione del nuovo sesso e nome”.
} 
identidade original, que não deve ser apagada, em respeito à história da própria pessoa, que igualmente compõe sua dignidade.

Assim, afastadas as posições extremadas, opta-se pela tese intermediária.

De fato, à luz do quadro esboçado, acredita-se que a melhor alternativa é admitir a anotação do art. 21, parágrafo único, da Lei n 6015/73, de que "a presente certidão envolve elementos de averbação à margem do termo", sem especificar o teor de tais elementos. Trata-se de tornar pública a existência da alteração, sem demasiada exposição do transexual, haja vista que a certidão não conteria a informação da modificação do nome e do sexo do indivíduo, sem mencionar explicitamente a extensão e o conteúdo da alteração.

Na dicção de Júlia C. R. da Cunha Mota, mais acertado é o entendimento que mantém à margem do livro "todos os dados necessários à identificação da retificação realizada, entretanto esses dados só serão 'públicos' na eventual expedição de uma certidão verbum ad verbum, ou seja, a requerimento do próprio registrado ou por determinação judicial", 777

A solução proposta, quer-se crer, preserva a pessoa transexual e atende à veracidade e continuidade do registro. Torna pública a existência de mudança, mas não seu conteúdo. Assim, garante a proteção da vida privada e do interesse público, na medida em que mantém o segredo quanto ao objeto da alteração, ao mesmo tempo queassegura a possibilidade de acesso à integralidade da informação, pela via judicial, em caso de demonstração do legítimo direito de saber do interessado.

Admitir a anotação do parágrafo único, do art. 21, da Lei dos Registros Públicos, nas certidões de nascimento do transexual, outrossim, mostra-se coerente com a irretroatividade dos efeitos da averbação, em respeito à vida passada da pessoa. Divulgar-se-ia apenas a notícia de que "a presente certidão envolve elementos de averbação à margem do termo", com a indicação da respectiva data.

Assim, limitada a questão à técnica do registro em relação à forma e publicidade do reconhecimento da identidade sexual, conclui-se que a mudança de nome e sexo deve ser promovida por meio de averbação no assento de nascimento da pessoa, admitindo-se a anotação do art. 21, parágrafo único da Lei no 6015/1973, mas

\footnotetext{
${ }^{777}$ MOTA, Júlia Cláudia Rodrigues da Cunha. O registro civil de pessoas naturais e o transexual, cit., p.
} 151. 
assegurando-se a intimidade da pessoa transexual pelo sigilo do conteúdo da mudança, cuja publicidade estará restrita às hipóteses de pedido do interessado ou requisição judicial.

Importante trazer, ainda, objeção sempre lembrada nas decisões que negam a mudança do sexo no registro, baseadas na boa-fé de terceiros, com quem a pessoa que tenha se submetido à cirurgia de redesignação venha a estabelecer relações afetivas.

Argumenta-se que a alteração registral acabaria expondo aqueles que, na crença de se tratar de homem ou mulher natural, amparados na presunção de veracidade do registro, iniciassem envolvimento afetivo com pessoa transexual, podendo até chegar ao casamento.

Na leitura de Benedito Silvério Ribeiro, a retificação do assento do transexual para constar o sexo de identificação seria algo falso, "pois o habilitaria para o casamento e induziria terceiros a erro, além de que em seu organismo não estão presentes todas as características de tal sexo". 778

A regra de publicidade ora proposta aparentemente contribui para arrefecer a questão, na consideração de que a própria anotação do parágrafo único, do art. 21, da Lei dos Registros Públicos, mitiga o risco de enganos e enfraquece as objeções calcadas na indução a erro de terceiros.

De fato, ainda que não haja menção explícita quanto ao conteúdo da alteração, a expressão "a presente certidão envolve elementos de averbação à margem do termo" autoriza presumir a existência de uma mudança que dificilmente passará despercebida pelo futuro cônjuge, atendendo à segurança, veracidade e certeza dos registros, sem expor o transexual a constrangimentos desnecessários.

Especificamente quanto à ponderação dos valores envolvidos no cotejo entre a publicidade dos registros e o direito dos terceiros, Maria de Fátima Freire de Sá e Bruno Torquato de Oliveira Neves sustentam que o direito à intimidade da pessoa prevalece sobre princípio da publicidade. Afirmam, nesse diapasão, a obrigação do transexual de informar ao cônjuge, a fim de não caracterizar o error in persona, que autorizaria a anulação do casamento ou a separação judicial. ${ }^{779}$ Reconhecem os doutrinadores que a proteção aos terceiros de boa-fé é o argumento mais forte que se opõe

\footnotetext{
${ }^{778}$ Análise de Casos que Implicam Alterações no Registro Civil. in Serviços Notariais e de Registro. Teses Apresentadas no Primeiro Simpósio Nacional de Serviços Notariais e Registrais de São Paulo, de 11 a 13 de setembro de 1996. Editado por Associação dos Notários e Registradores do Estado de São Paulo e Associação dos Serventuários de Justiça do Estado de São Paulo, p. 142.

779 SÁ, Maria de Fátima Freire e NAVES, Bruno Torquato de Oliveira. Transexualismo. Manual de Biodireito, cit., p. 264.
} 
à alteração no registro do transexual, "porque busca o bem-estar do outro, e a dignidade humana não pode ser aferida senão na intersubjetividade". ${ }^{780}$ Contudo, mesmo assim, são favoráveis à mudança do estado civil, argumentando que a possibilidade de engano do parceiro já existe em situações outras, como no caso da bissexualidade e da homossexualidade, hipóteses tuteladas pelo Direito pela previsão de anulação por erro essencial.

Cumpre ponderar, também, que as relações afetivas obedecem a regras próprias, padrões de honestidade estabelecidos pelos sujeitos de acordo com seu caráter e formação, tratando-se de esfera da vida privada na qual não cabe ao Estado interceder, como inclusive expresso no art. 1.513, do Código Civil. ${ }^{781}$

Por isso, o risco de haver omissão no que toca à mudança de sexo, salvo melhor juízo, não autoriza negar o direito à identidade sexual e a averbação do novo sexo no registro civil, tratando-se de eventualidade presente na vida coletiva. A possibilidade de falseamento da verdade é da realidade da vida, estendida inclusive a outras hipóteses de ofensa à boa-fé do companheiro ou cônjuge, como adultério, alcoolismo e drogadição, por exemplo, sem que se cogite restringir direitos essenciais da personalidade aos faltosos.

Ao contrário, a sanção aplicável na hipótese de um parceiro enganar-se quanto à identidade do outro já é prevista pelo Direito, consistente na anulação do casamento por erro essencial, nos moldes do art. 1.557, I, do Código Civil, do que aparentemente resulta a inviabilidade de negar o direito à identidade sexual e ao respectivo registro da mudança de sexo, com base na proteção da boa-fé dos terceiros.

Daí se entender que o reconhecimento do direito à identidade sexual como projeção da pessoa, entre os direitos da personalidade, reclama a não publicidade do registro no que toca às mudanças de nome e sexo, embora se preveja a inclusão da anotação prevista no parágrafo único, do art. 21, da Lei no 6015/73, nas certidões respectivas.

Quanto aos reflexos da averbação da mudança do nome e do sexo em relação à pessoa do cônjuge e aos filhos anteriores, o tema será abordado nos itens relativos ao casamento e à filiação, respectivamente.

\footnotetext{
${ }^{780}$ Idem, p. 269.

781 Art. 1513. É defeso a qualquer pessoa, de direito público ou privado, interferir na comunhão de vida instituída pela família.
} 


\section{0.b) Casamento}

A abordagem dos direitos dos transexuais ao casamento pressupõe a divisão do tema em duas situações: a dos transexuais solteiros e a dos transexuais anteriormente casados. A análise, então, não se limita à possibilidade de casamento futuro, estendendo-se também aos reflexos da averbação da mudança de nome e sexo sobre o casamento anterior da pessoa.

\section{0.b.1) A situação do transexual solteiro}

Admitida a averbação da mudança de sexo no registro civil, desaparece o impedimento da igualdade entre os sexos como obstáculo ao casamento e à família, como exposto no item anterior. Daí a importância do reconhecimento da identidade sexual para o gozo de direitos.

Note-se que a efetivação da dignidade e a concretização da igualdade em relação às pessoas transexuais pressupõem assegurar-lhes possibilidades plenas de usufruírem o novo estado sexual, tratando-se de preocupação presente na legislação alienígena.

A garantia de direitos com base no estatuto do novo sexo é expressa na lei alemã, de 10 de setembro de 1980, cujo $\S 10$ estabelece que os direitos e obrigações referidos ao sexo serão regulamentados com base nas normas atinentes ao novo sexo. $^{782}$

Consta também na Recomendação do Conselho da Europa, de 29 de setembro de 1989, solicitando aos Estados que legislem sobre a transexualidade, de modo a proibir qualquer forma de discriminação, de restrição de liberdade e de direito fundamental, o que, na interpretação de Javier Perona, estende-se ao casamento. A Resolução do Parlamento Europeu, de 12 de setembro de 1989, outrossim, ao instar os Estados membros a elaborar normas contra a discriminação dos transexuais, sugeriu o reconhecimento jurídico da pessoa transexual e a correção do sexo no assento de nascimento, sem qualquer ressalva ou limitação. ${ }^{783}$

Essas orientações foram seguidas na elaboração da lei inglesa.

Nos termos do art. 9, do Gender Recognition Act, de 2004: "Após a expedição do certificado de reconhecimento de gênero definitivo, o gênero da pessoa passa a ser o gênero adquirido para todas as finalidades (assim, se o gênero adquirido é o masculino, a

\footnotetext{
${ }^{782}$ PERONA, Javier. La problemática jurídica de la transexualidad, cit., p. 338.

${ }^{783}$ Idem, p. 339.
} 
pessoa passa a ser considerada homem e, se o gênero adquirido for o feminino, a pessoa passa a ser considerada mulher)" (tradução livre) ${ }^{784}$ do que resultaria, em comparação com o que ocorre no Brasil, a aptidão para o casamento.

Do mesmo teor a legislação espanhola. Na dicção do art. 5.2, da Lei $\mathrm{n}^{\mathrm{o}} 3 / 2007$, a mudança no registro permitirá à pessoa exercer todos os direitos inerentes à sua nova condição, ${ }^{785}$ o que significa a possibilidade do gozo de direitos próprios do novo sexo, entre os quais o casamento. Nesse sentido, Yolanda Moreno alude ao princípio da equiparação plena com o novo sexo, introduzido pelo art. 5.2, vedando as limitações que o Tribunal Espanhol estendia ao casamento, antes da edição de referida lei. ${ }^{786}$

Entre nós, José Roberto Neves Amorim e Vanda Lúcia Cintra Amorim, após afirmarem que não se permite o casamento entre pessoas do mesmo sexo, ponderam que, admitida a adequação da pessoa ao seu gênero de identificação, de rigor concluir "que se permite a união matrimonial de pessoa que tenha obtido sua transformação sexual". ${ }^{787}$

Cabe, então, reiterar a necessidade de atribuir à pessoa transexual o direito ao casamento e à união estável com base no novo sexo, de modo a reconhecer de fato a identidade sexual como um direito da personalidade correlato à dignidade humana. É na garantia da igualdade dos mesmos direitos gozados por quem pertence a determinado sexo que se verifica a efetividade do direito à identidade sexual, vedando-se tratamentos discriminatórios no que toca ao casamento.

No Brasil, discute-se sobre a situação do outro cônjuge, que desconhecesse a situação anterior à cirurgia. Conclui a doutrina que a melhor opção é aquela que admite a anulação do casamento por erro essencial quanto à pessoa. ${ }^{788}$

Nesse sentido, afirma Adriana Dabus Maluf, ao sustentar que o casamento de um transexual com alguém que desconhecesse tal condição seria anulável, por erro essencial e pela presença de defeito físico irreparável (CC art. 1557, III) ${ }^{789}$

\footnotetext{
784 9. General (1) Where a full gender recognition certificate is issued to a person, the person's gender becomes for all purposes the acquired gender (so that, if the acquired gender is the male gender, the person's sex becomes that of a man and, if it is the female gender, the person's sex becomes that of a woman) ".

${ }^{785}$ Ley 3/2007: “Artículo 5 (...) 2.La rectificación registral permitirá a la persona ejercer todos los derechos inherentes a su nueva condición”.

${ }^{786}$ La transexualidad, cit., p. 304.

${ }^{787}$ Direito ao nome da pessoa física. Rio de Janeiro: Elsevier, 2010, p. 63.

${ }^{788}$ SANTOS, Reinaldo Velloso dos. Registro Civil das Pessoas Naturais. Porto Alegre: Fabris, 2006, p. 182.

${ }^{789}$ MALUF. Adriana Caldas do Rego Freitas Dabus. Casamento inexistente, nulo e anulável. in Revista do Advogado AAASP. Ano XXVIII, nº 98, julho de 2008, p.32.
} 
Elimar Szaniawski lembra a hipótese do transexual operado, que não obteve a modificação do registro civil, para quem o casamento estaria vedado em razão da identidade entre os sexos. ${ }^{790}$

Sob esse aspecto, cabe trazer as recentes decisões do Supremo Tribunal Federal, na ADI 4277 e na ADPF 132, que deram interpretação conforme à Constituição Federal, para excluir qualquer significado do art. 1.723, do Código Civil, que impeça o reconhecimento da união entre pessoas do mesmo sexo como entidade familiar. ${ }^{791}$ Com base em tal decisão, autorizado o reconhecimento do direito à família a transexuais que não tenham obtido a mudança do registro, nos mesmos moldes que se assegura o direito aos casais formados por pessoas do mesmo sexo.

No julgamento do caso paradigmático já analisado, Christine Goodwin contra Reino Unido, a Corte Europeia de Direitos Humanos, ao reconhecer a nova identidade do transexual, abandonou o critério biológico para definir o casamento, revelando uma aproximação compassiva dos direitos humanos e "uma interpretação não apenas 'dinâmica' ou 'consensual', mas antes 'construtiva' da Convenção. ${ }^{792}$ O Tribunal entendeu que, diante da evolução social do casamento, das mudanças que a medicina e a ciência trouxeram para entender a transexualidade, e do art. $9^{\circ}$ da Carta de Direitos Fundamentais da União Europeia, o qual não alude ao sexo dos cônjuges, não haveria fundamento para impedir ao transexual contrair casamento, concluindo pela violação do art. 12, da Convenção. ${ }^{793}$

Assim, conclui-se que a interpretação mais afinada com os direitos humanos é aquela que permite o casamento do transexual, independentemente da averbação da mudança de sexo no registro civil.

\section{0.b.2) A situação do transexual anteriormente casado}

Elimar Szaniawski, com apoio em Harry Benjamin, atenta para a hipótese do estado de latência da transexualidade, que acaba por se manifestar após o casamento e a existência de filhos. ${ }^{794}$ Indaga, então, sobre a possibilidade de o transexual casado realizar a cirurgia de redesignação sexual.

\footnotetext{
${ }_{790}^{79}$ Limites e possibilidades do direito de redesignação do estado sexual, cit., p. 127. www.stf.jus.br/portal/cms/verNoticiaDetalhe.asp?idConteudo=178931, último acesso em 01/12/2011.

792 ALMEIDA, Suzana. O respeito pela vida (privada e) familiar na jurisprudência do Tribunal Europeu dos Direitos do Homem: a tutela das novas formas de família, cit., p. 226.

${ }^{793}$ Idem, p. 238/239.

${ }^{794}$ Limites e possibilidades do direito de redesignação do estado sexual, cit., p. 122.
} 
Szaniawski defende que é possível o transexual casado submeter-se à intervenção corporal para a mudança de sexo, desde que obtenha o consentimento expresso e inequívoco do outro cônjuge. O casamento permanece válido, se não houver a alteração do sexo civil. Contudo, entende que a melhor alternativa é realizar a cirurgia somente em transexuais solteiros, viúvos ou previamente divorciados, acrescentando que, caso o divórcio não tenha ocorrido, caberá ao juiz, no ato do deferimento da mudança de prenome e de sexo no registro civil, decretar o divórcio do casal. $^{795}$

Adriana Dabus Maluf sustenta que a redesignação de um cônjuge na constância do casamento leva ao divórcio, pois não se pode impor ao outro uma convivência homossexual. Entende que não se pode falar em casamento inexistente, nulo ou anulável, à vista da anterior consumação, antes da cirurgia. ${ }^{796}$

A extinção do casamento é a solução dada pela lei italiana, que prevê a notificação do cônjuge e dos filhos, no processo judicial em que se pretende a mudança de nome e sexo (Lei $\mathrm{n}^{\circ} 164 / 1982$, art. $2^{\circ}$ ), sendo expressa ao determinar que a modificação do registro implica a dissolução do casamento ou a cessação dos efeitos civis do casamento religioso, remetendo à lei do divórcio (art. $4^{\circ}$, Lei 164/1982). ${ }^{797}$

No Reino Unido, a existência de casamento ou parceria civil implica a expedição de um certificado provisório de reconhecimento de gênero, apenas tornado definitivo após a dissolução da união ou do divórcio (Gender Recognition Act, 4 (3), 5 (6) (a) e $5(7)) .{ }^{798}$

$\mathrm{Na}$ Alemanha e na Turquia, permitido iniciar o procedimento judicial para a mudança de sexo apenas após o fim do casamento e a dissolução do vínculo matrimonial. $^{799}$

O estado de não casado deixou de ser exigido no Código Civil de Quebec. Referida lei especificamente trata da mudança do sexo, na Seção IV, do

\footnotetext{
${ }^{795}$ Idem, p. 125 e 126.

${ }^{796}$ MALUF. Adriana Caldas do Rego Freitas Dabus. Casamento inexistente, nulo e anulável. in Revista do Advogado AAASP. Ano XXVIII, nº 98, julho de 2008, p. 35.

${ }^{797}$ Art. 4 La sentenza di rettificazione di attribuzione di sesso non ha effetto retroattivo. Essa provoca lo scioglimento del matrimonio o la cessazione degli effetti civili conseguenti alla trascrizione del matrimonio celebrato com rito religioso. Si apllicano le disposizioni del codice civile e della legge $1^{\circ}$ dicembre 1970, $n$. 898, e successive modificazione. Disponível em: www.t-girl.it/1-dis/1.6-leg/1.6.1-legge 164-82.htm, último acesso em $1 \% 12 / 2011$.

7984 (3) "If the applicant is married or a civil partner, the certificate is to be an interim gender recognition certificate"; 5 (6) (a) "The Panel must grant the application if satisfied that the applicant is neither married nor a civil partner, and (b) otherwise must reject it"; 5 (7) "If the Panel grants the application it must issue a full gender recognition certificate to the applicant".

${ }^{799}$ MORENO, Yolanda. La transexualidad, cit., p. 299.
} 
Capítulo I, do Título Três, no art. 71. Na redação anterior, somente pessoas não casadas podiam fazer o requerimento para a mudança do nome e do sexo. ${ }^{800}$ Tal requisito foi retirado e não consta no novo texto do mesmo artigo, atualizado até 22 de julho de $2008 .{ }^{801}$

Aponta Yolanda Moreno que, perante a lei espanhola, a retificação no registro não afeta a situação matrimonial do transexual, que poderá ou não continuar casado, a critério dos cônjuges, haja vista que se admite o casamento entre pessoas do mesmo sexo naquele país. ${ }^{802}$

Pela lei portuguesa, igualmente, admite-se a retificação do registro do transexual casado, inclusive nos assentos de nascimento e de casamento do outro cônjuge, desde que com seu consentimento expresso (Lei $\mathrm{n}^{\circ} 7 / 2011$, art. $5^{\circ}$, naquilo que altera os arts. $69^{\circ}$ e $70^{\circ}$, do Código de Registo Civil), ${ }^{803}$ sinalizando a possibilidade de manutenção do casamento mesmo após a alteração de sexo.

$\mathrm{Na}$ Alemanha, a lei transgendergesetz expressamente prevê a alteração do nome do transexual no registro de nascimento, independentemente da cirurgia de redesignação de sexo. Nos termos do art. 11, a retificação do nome no próprio assento não produz modificações no registro de casamento, a não ser que haja requerimento conjunto de ambos os cônjuges. ${ }^{804}$ Já para a alteração do sexo, referente à "grande solução", a mesma lei exige que a pessoa não seja casada, tenha se divorciado ou requerido

\footnotetext{
800 "71 Every person who has successfully undergone medical treatments and surgical operations involving a structural modification of the sexual organs intended to change his secondary sexual characteristics may have the designation of sex which appears on his act of birth and, if necessary, his given names changed. Only an unmarried person of full age who has been domiciled in Québec for at least one year and is a Canadian citizen may make an application under this article".

801 "71 Every person who has successfully undergone medical treatments and surgical operations involving a structural modification of the sexual organs intended to change his secondary sexual characteristics may have the designation of sex which appears on his act of birth and, if necessary, his given names changed. Only a person of full age who has been domiciled in Québec for at least one year and is a Canadian citizen may make an application under this article".

${ }^{802}$ La transexualidad, cit., p. 299.

${ }^{803}$ Lei portuguesa $n^{\text {o }} 7 / 2011$ disponível em: <dre.pt/pdf1sdip/2011/03/05200/0145001451.pdf>, último acesso em 15/11/2011.

804 Texto do artigo obtido pela tradução italiana da lei alemã transgendergesetz: Legge per la scelta o il cambio di nome e per la determinazione del sesso di appartenenza. Legge teddesca, in www.azionetrans.it/leggetedesca.html, último acesso em 1\%/12/2011: Art. 11 - Matrimonio - Matrimonio e rapporti assimilati non vengono modificati dall'art. 6 di questa legge. Nel certificato di matrimonio e nel contratto matrimoniale il nome puó essere cambiato solo se entrambe le parti fanno richiesta contestuale. Sono competenti le stesse autorità competenti anche per il cambio di nome. Se una persona vuole contrarre matrimonio, può farlo solo nella forma Che è resa possible del sexo indicato nel suo atto di nascita, independentemente dal nome in vigore al momento. Deve essere comunque usato il nome in vigore al momento".
} 
a conversão do matrimônio em união de fato, estabelecendo o divórcio em consequência da mudança de sexo. ${ }^{805}$

Entre nós, esse é o entendimento de Maria Helena Diniz, para quem a cirurgia de conversão de sexo, para evitar constrangimento ao cônjuge, só poderá ser feita em transexual solteiro, viúvo ou divorciado. ${ }^{806}$ No mesmo sentido sustenta Ana Paula Barion Peres, acreditando que o casamento anterior, enquanto não desfeito, constituirá sempre um óbice à realização da cirurgia. ${ }^{807}$

Afirma Adriana Caldas do Rego Freitas Dabus Maluf, com apoio em Yussef Said Cahali, que a aquiescência do cônjuge não abalaria a validade do casamento, enquanto a falta de concordância configuraria conduta desonrosa e grave violação aos deveres do casamento, pois seria uma violação à personalidade do outro. ${ }^{808}$

$\mathrm{Na}$ hipótese de o transexual ser casado ou divorciado, seria necessário averbar a mudança de nome e sexo também no Registro Civil de casamento, uma vez que seu estado civil é comprovado pela certidão de casamento e não pela certidão de nascimento.

Contudo, em proteção à pessoa do cônjuge, sustenta Luiz Alberto David de Araújo que os assentos de casamento permaneçam os mesmos, salvo acordo entre as partes. ${ }^{809}$

Essa solução foi adotada pela Lei portuguesa $n^{\circ} 7 / 2011$, que alterou o art. $69^{\circ}$, do Código de Registo, para determinar que o fato da mudança de nome e sexo somente seja averbado na certidão de casamento, se houver o consentimento do outro cônjuge, prestado por escritura pública ou documento autenticado (art. $5^{\circ}$, da Lei $\mathrm{n}^{\mathrm{o}}$ $7 / 2011)^{810}$

\footnotetext{
805 Texto do artigo obtido pela tradução italiana da lei alemã transgendergesetz: Legge per la scelta o il cambio di nome e per la determinazione del sesso di appartenenza. Legge teddesca, in www.azionetrans.it/leggetedesca.html, último acesso em 1\%/12/2011: Art. 12 - Requisiti - Il tribunale, su richiesta di una persona Che non si riconosce nel sesso registrato nell'atto di nascita, decide riguardo all'appartenenza all'altro sesso della persona stessa quando: - è stato eseguito il cambio di nome - la persona non è sposata o ha fatto domanda di divorcio o ha fatto richiesta di trascrivere il matrimonio come unione di fatto - la persona dimostra di avere intrapreso le misure mediche necessarie per rassomigliare nelle caratteristiche esteriori al modello estetico del sesso di arrivo. La causa di divorzio viene fatta presso lo stesso tribunale competente per il cambio dello stato civile.Se il divorzio viene richiesto da una sola delle parti, allora diviene competente il tribunale che decide anche sul cambio di sesso. Se non viene raggiunto um accordo tra le parti il tribunale delibera lo scioglimento del matrimonio. Le altre norme previste dalla legge sul divorzio rimangono inviolate".

${ }^{806}$ O estado atual do biodireito. $4^{a}$ ed. São Paulo: Saraiva, 2007, p. 268.

${ }^{807}$ Transexualismo. O direito a uma nova identidade sexual, cit., p. 215.

${ }^{808}$ Casamento inexistente, nulo e anulável. in Revista do Advogado AAASP. Ano XXVIII, $\mathrm{n}^{\circ}$ 98, julho de 2008, p. 33 (12-37).

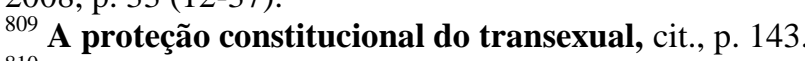

${ }^{810}$ Disponível em: <dre.pt/pdf1sdip/2011/03/05200/0145001451.pdf>, último acesso em 03/12/2011.
} 
Na hipótese de divórcio ou prole, sustenta Júlia C. R. da Cunha Mota que o pedido de alteração do prenome e do sexo deve ser indeferido, a fim de evitar constrangimentos às outras pessoas envolvidas, como o ex-cônjuge e os filhos. ${ }^{811}$

Constata-se, assim, a complexidade da situação, que encontra tratamentos variados pelos autores e legislações.

No Brasil, na ausência de lei, mais difícil se torna o enquadramento jurídico da questão, o qual se sugerirá, ciente de que a discussão ainda é incipiente e de que o tema precisa ser mais amadurecido.

Com base no exposto, razoável parece admitir tanto a operação, quanto a retificação de nome e sexo ao transexual casado, na perspectiva de que o casamento, na atualidade, volta-se à realização e não à opressão dos cônjuges. A doutrina, de fato, reiteradamente vem afirmando o enfraquecimento da importância institucional do matrimônio, prevalecendo, em seu lugar, uma concepção de casamento afinada com o desenvolvimento e a expansão da personalidade, em proteção da pessoa. Nesses moldes, ocorrendo a identificação com o sexo oposto no curso da vida, não deve o casamento anterior ser entendido como obstáculo ao acerto da identidade própria, sob pena do desvirtuamento da própria finalidade do casamento e da família.

Em resguardo ao outro cônjuge, cuja dignidade também é objeto de tutela, socorrem as legislações italiana, espanhola e portuguesa.

Assim, da ação proposta para a mudança de nome e sexo, deve ser notificado o cônjuge, abrindo-lhe oportunidade para se manifestar, decretando-se o divórcio se houver oposição e somente se procedendo às respectivas anotações na certidão de casamento, se houver o consentimento expresso do outro cônjuge.

\section{0.c) Filiação}

O tema da filiação pode ser abordado sob dois enfoques: de um lado, a possibilidade de admitir que o transexual tenha filhos futuros; e, de outro, a consequência do reconhecimento da identidade sexual em relação aos filhos anteriores. Inicia-se pela primeira abordagem, intimamente ligada à necessidade de cirurgia como condição para o reconhecimento da identidade sexual.

Como anota Elimar Szaniawski, a cirurgia transformadora, ao pressupor a retirada dos órgãos femininos internos e do órgão masculino externo, resulta na

${ }^{811}$ MOTA, Júlia Cláudia Rodrigues da Cunha. O registro civil de pessoas naturais e o transexual, cit., p. 154. 
impossibilidade física de procriar. ${ }^{812} \mathrm{Na}$ hipótese de prévia operação, destarte, eventual reprodução somente poderia ocorrer por meio da inseminação artificial homóloga ou heteróloga, de acordo com o estado da técnica e a legislação própria, mas sempre preservando a paridade entre o gênero de identificação e a função procriativa.

De todo modo, neste trabalho, em que o interesse maior se volta ao reconhecimento da identidade sexual, com e sem cirurgia, a possibilidade de reprodução por inseminação artificial não será abordada. O estudo limitar-se-á, assim, à hipótese de geração de filhos pelo transexual não operado, ou seja, à hipótese em que a identidade de gênero é reconhecida independentemente da cirurgia para a mudança de sexo, preservandose o aparelho reprodutor original, contraditório com o papel social assumido.

\section{0.c.1) A possibilidade de ter filhos após o reconhecimento}

\section{da identidade sexual}

Lembra Antonio Chaves que a impossibilidade de gerar pela esterilização ou a incapacidade de procriar por qualquer outro motivo é exigida pela Lei Sueca de 21/4/1972, como condição para que se proceda à verificação de que a pessoa pertença ao outro sexo. ${ }^{813}$ Segundo aquela legislação, a modificação do sexo no registro pode ser feita administrativamente, desde que a pessoa seja solteira e tenha se submetido à operação, ${ }^{814}$ do que resulta a impossibilidade de procriação futura.

Além da Suécia, com base na análise que efetua sobre o direito comparado, afirma Yolanda Moreno que a esterilização é requisito para a alteração do nome e do sexo no registro de nascimento da pessoa exigido na Holanda, Áustria e Finlândia, reconhecendo essa tendência no continente europeu. Na Alemanha e na Bélgica, a esterilização é exigida apenas para a alteração do sexo, mas não para a mudança do nome. Diversamente, Espanha, Inglaterra, Itália e Turquia não trazem esse requisito em suas legislações, ${ }^{815}$ podendo-se incluir Portugal nestes últimos, diante dos termos da recente Lei $\mathrm{n}^{\circ}$ 7/2011.

Mesmo sem cirurgia, a possibilidade de fecundação é remota. Argumenta-se que a exigência de esterilização seria inclusive desnecessária, pois a dificuldade de gerar resultaria do próprio tratamento hormonal a que se submete o

\footnotetext{
${ }^{812}$ Limites e possibilidades do direito de redesignação do estado sexual, cit., p. 139.

${ }^{813}$ Castração. Esterilização. Mudança artificial de sexo. Revista Forense, vol. 276, ano 77, out-dez/1981, p. 14 (p. 2-19).

${ }^{814}$ PERONA, Javier López-Galiacho. La problemática jurídica de la transexualidad, cit., p. 151.

${ }^{815}$ MORENO, Yolanda B. Bustos. La transexualidad, cit., p. 170.
} 
transexual. ${ }^{816}$ Nesse sentido, ressalta Yolanda Moreno a dificuldade da fecundação natural, em decorrência do tratamento hormonal. ${ }^{817}$

Mesmo assim, a realidade traz situações sensacionalistas, como a do homem grávido, valendo refletir sobre as consequências do reconhecimento da identidade sexual a pessoas não operadas, no que toca à procriação. Em última instância, o ponto implica pensar se seria ou não admitido ao transexual gerar em contradição com sua identidade sexual.

A questão não é simples e certamente merece maior reflexão por parte da doutrina e da jurisprudência. Envolve a ponderação, de um lado, do gozo dos direitos reprodutivos e, de outro, a perplexidade diante da incongruência entre o papel apropriado à identidade de gênero e a participação físico-biológica na procriação.

Em princípio, a resposta é negativa, pela impossibilidade de gerar em contradição com a identidade de gênero, em consequência dos deveres éticos de autorresponsabilização pelas expectativas criadas, ainda que se reconheça a dificuldade de exigir tal comportamento, se dispensada a cirurgia de mudança de sexo.

$\mathrm{Na}$ lição de Teubner, citado por Menezes Cordeiro, o comportamento contraditório configura-se um atentado "contra expectativas fundamentais de continuidade da auto-representação que respeitam também a identidade do parceiro e a sua relação bilateral". ${ }^{818}$ Assim, ainda que não se possa propriamente aplicar a figura do abuso do direito em relação aos direitos existenciais, ${ }^{819}$ a confiança inspirada na sociedade com base no comportamento, aparência e pretensão de reconhecimento exibida pela pessoa, desaguando no reconhecimento da identidade sexual, acaba por limitar as possibilidades individuais de ação, em prol da manutenção da expectativa legítima criada pelo comportamento anterior.

Menezes Cordeiro refere também à lição de Niklas Luhmann, para quem “toda a auto-representação obriga - só porque ela representa um 'auto' que será aproveitado para a identidade. Se se quer ficar o mesmo, deve-se permanecer como sempre se mostrou". 820

\footnotetext{
${ }^{816}$ Rel Maria Berenice Dias, TJ/RS, 7 a Câmara Cível, Apelação Cível n. 70013909874/2005, j. 05/04/2006, p. 11.

${ }_{817}$ MORENO, Yolanda B. Bustos. La transexualidad, cit., p. 170.

${ }^{818}$ Da boa-fé no direito civil. Coimbra: Almedina, 2001, p. 750/751.

819 SESSAREGO, Carlos Fernandéz. Abuso del derecho. Buenos Aires: Editorial Astrea, 1992, p. 168/170.

820 Apud MENEZES CORDEIRO, António Manuel da Rocha e. Da boa-fé no direito civil. Coimbra: Almedina, 2001, nota de rodapé no 396, p. 751.
} 
Transpostas as lições para o ponto analisado, tem-se que, assumida a identificação com o sexo oposto e atendida a pretensão de reconhecimento da identidade de gênero, a coerência de comportamento para a manutenção da mesma identidade, no sentido emprestado de Luhmann, pressupõe o não exercício da capacidade reprodutiva baseada no sexo físico e biológico rejeitado pela pessoa, sob pena de contradição que compromete a própria possibilidade de permanência da identidade sexual.

Note-se que tal limitação, ao que parece, não implica restrição indevida da liberdade, mas, ao contrário, volta-se à tutela da dignidade da identidade daquele que se pretende reconhecido pelo sexo oposto. Evita a exposição da pessoa transexual como uma aberração, além de proteger sua prole de constrangimentos, mantendo-se a coerência entre a identidade sexual e o papel exercido perante os filhos, como pai ou mãe, de acordo com a mesma identidade.

Cumpre anotar, outrossim, que admitida a transexualidade como uma identificação com o gênero contrário, que leva a pessoa a se sentir como pertencente ao outro sexo, razoável supor que essa identificação se reflita igualmente no que toca aos papéis de pai e mãe. Por isso, eventual gravidez de quem se assume socialmente como homem ou o fornecimento de esperma por quem se apresenta como mulher não deixa de significar uma contradição que suscita uma dúvida sobre a estabilidade da identificação e sobre a própria verdade da identidade sexual, o que novamente remete à importância do tratamento e do acompanhamento da pessoa por equipe multidisciplinar, por determinado período, até que se proceda à alteração do estado.

Cabe afirmar, por fim, que a conclusão de que deve ser evitada a procriação em contradição com a identidade sexual não significa, contudo, a impossibilidade de exercer a paternidade ou a maternidade. De fato, a limitação dela decorrente limita-se à reprodução natural, subsistindo a possibilidade da adoção.

Nesse sentido, sustenta Elimar Szaniawski que a melhor e mais justa solução para o transexual que deseje ser pai ou mãe é a adoção, pelo autor apontada como o método mais simples e saudável nessa situação. ${ }^{821}$ Ana Paula Barion Peres, no mesmo sentido, após considerar viável do ponto de vista médico a inseminação artificial, entende mais prudente que o transexual se valha do instituto da adoção. ${ }^{822}$

Nesse contexto, o direito do transexual à parentalidade poderia ser tutelado por meio da adoção, forma jurídica prevista no direito para atribuir a filiação a

${ }^{821}$ Limites e possibilidades do direito de redesignação do estado sexual, cit., p. 156.

${ }^{822}$ Transexualismo. O direito a uma nova identidade sexual. Rio de Janeiro: Renovar, 2001, p. 239. 
quem não pode ser mãe ou pai biológico. Na ação de adoção, por sua vez, caberia a observância do princípio do melhor interesse da criança, com vistas a atender sua condição peculiar de pessoa em desenvolvimento, sempre prevalente sobre o interesse dos adotandos.

\section{0.c.2) A situação dos filhos havidos anteriormente à}

\section{mudança de sexo}

A existência de filhos anteriores não é encarada como impedimento para a mudança de sexo pela doutrina ${ }^{823}$ nem pelas legislações Europeias.

Da regra adotada nos países europeus, sobre a irretroatividade da averbação da mudança do nome e do estado, resulta que a relação da pessoa transexual com seus filhos anteriores não é atingida, ${ }^{824}$ preservando-se os mesmos direitos e obrigações.

Nesse sentido, o art. 15 da lei alemã estabelece que a decisão de mudança de sexo no registro do genitor não altera o vínculo entre pais e filhos, ${ }^{825}$ assim como o art. $62, \S 8$, do Código Civil belga, ${ }^{826}$ e o n. 12, do Gender Recognition Act, do Reino Unido. ${ }^{827} \mathrm{Na}$ Turquia, é obrigatória a intervenção do cônjuge no processo em que se postula a mudança de sexo, para decidir sobre o poder familiar dos filhos comuns. ${ }^{828}$

Entre nós, Maria Helena Diniz sustenta que os direitos e deveres do transexual para com seus filhos permanecem inalterados, desde que não haja dano moral ou material à educação da prole, ressaltando a inexistência de causa de impedimento ao exercício do poder familiar. ${ }^{829}$

Nessa quadra, em que pese a ausência de efeitos imediatos provocados pela identidade de gênero na relação entre pais e filhos, a doutrina reconhece a

\footnotetext{
${ }^{823}$ ARAUJO, Luiz Alberto David. A proteção constitucional do transexual, cit., p. 145; SZANIAWSKI, Elimar. Limites e possibilidades do direito de redesignação do estado sexual. São Paulo: RT, 1999, p. 137. DINIZ, Maria Helena. O estado atual do biodireito, cit., p. 268/269.

${ }^{824}$ MORENO, Yolanda B. Bustos. La transexualidad, cit., p. 298/299.

${ }^{825}$ Texto do artigo obtido pela tradução italiana da lei alemã transgendergesetz: Legge per la scelta o il cambio di nome e per la determinazione del sesso di appartenenza. Legge teddesca, in www.azionetrans.it/leggetedesca.html, acesso em 01/12/2011: Art. 15 - Rapporti tra genitori e figli - La decisione sul cambio di sesso non modifica i rapporti giuridici tra genitori e figli e viceversa. La presente norma non vale per i figli adottivi se questi sono stati adottati dopo la sentenza del tribunale.

${ }^{826} \S 8$. L'acte portant mention du nouveau sexe ne modifie em rien les lien de filiation existants, ni le droit, pouvoirs et obligations qui en découlent. Toutes les actions concernant ces lien de filiation e le droits, pouvoirs et obligations qui en découlent peuvent encore être intentées aprés l'établissement de l'acte portant mention du nouveau sexe.

${ }^{827} 12$ Parenthood. The fact that a person's gender has become the acquired gender under this Act does not affect the status of the person as the father or mother of a child.

${ }^{828}$ PERONA, Javier López-Galiacho. La problemática jurídica de la transexualidad, cit., p. 154/155.

${ }^{829} \mathrm{O}$ estado atual do biodireito, cit., p, 268/269.
} 
possibilidade de advirem restrições ao poder familiar do transexual, sempre à luz do melhor interesse da criança, na hipótese de ficar demonstrado que o convívio possa prejudicar o desenvolvimento infantil.

Devem ser avaliados pelo juiz, caso a caso, a idade, a maturidade da criança, sua adaptação à nova situação do pai ou mãe e o grau de assimilação da situação de eventualmente vir a ter dois pais ou duas mães, sempre de modo a adequar o exercício do poder familiar ao melhor interesse. ${ }^{830}$ Como anota Luiz Alberto Davi Araújo, a gravidade dos efeitos da alteração do sexo varia de núcleo familiar para núcleo familiar, ${ }^{831}$ não se podendo, de antemão, fixar uma única fórmula de regulação dos direitos parentais do transexual, cuja extensão dependerá das circunstâncias do caso concreto.

Do emblemático elenco que Szaniawski traz, vale citar exemplos nos Estados Unidos, que ilustram a impossibilidade de estabelecer uma regra. No primeiro caso, a guarda foi deferida ao transexual, enquanto, no segundo, houve a suspensão da convivência pelo reconhecimento de que causaria danos psicológicos aos filhos, ${ }^{832}$ a corroborar a assertiva de que a definição jurídica da relação da pessoa transexual redesignada com seus filhos dependerá da hipótese concreta.

Resta indagar sobre os efeitos do registro do novo prenome e sexo no assento de nascimento dos filhos havidos anteriormente à mudança.

Sustenta Elimar Szaniawski que a existência da redesignação não deverá aparecer jamais nos documentos dos filhos, preservando a imutabilidade de seus assentos de nascimento. ${ }^{833}$ Luiz Alberto David Araújo, no mesmo sentido, entende que não há necessidade de fazer a averbação do novo nome no assento de nascimento dos filhos nascidos antes da mudança de sexo. ${ }^{834}$

Desse entendimento compartilha a registradora Júlia Claudia Cunha Mota, a fim de preservar a prole do constrangimento de ter dois pais ou duas mães anotadas em seu assento de nascimento, quando a família da criança sempre fora formada por um casal heterossexual e assim reconhecida no seio da sociedade. ${ }^{835}$

\footnotetext{
${ }^{830}$ PERONA, Javier López-Galiacho. La problemática jurídica de la transexualidad, cit., p. 310.

${ }^{831}$ A proteção constitucional do transexual, cit., p. 145.

${ }^{832}$ Limites e possibilidades do direito de redesignação do estado sexual, cit., p. 138.

${ }^{833}$ Idem, mesma página.

${ }^{834}$ A proteção constitucional do transexual, cit., p. 143.

${ }^{835}$ MOTA, Júlia Cláudia Rodrigues da Cunha. O registro civil de pessoas naturais e o transexual, cit., p. $151 / 152$.
} 
Não há dúvida de que a mudança de nome e sexo do pai ou da mãe, a certa altura da vida, pode ser fonte de exposição e angústia nos filhos. Nesse caso, o conflito de bens envolve, de um lado, a dignidade da pessoa transexual cujo reconhecimento da identidade de gênero implica consequências nos demais assentos em que figurar e, de outro, a dignidade dos filhos, a quem se garante o direito à genealogia natural em proteção da origem pessoal.

A ponderação não é simples, considerando que os bens jurídicos envolvidos, quais sejam, as dignidades de diferentes pessoas, possuem valores semelhantes. As normas aplicáveis aos registros auxiliam no desate da questão.

Considerando a já defendida irretroatividade da averbação para a mudança do nome e do sexo, a solução do conflito parece estar na proteção da pessoa do filho, mantendo intacto seu assento de nascimento, lavrado com base na identidade civil ostentada à época pelo pai ou pela mãe. Dessa forma, mantém-se a exata correspondência entre o registro e a realidade do momento do nascimento, atendendo aos princípios da veracidade e segurança dos registros.

Interessante a disposição da recente lei portuguesa, de 2011. Na regulação dos efeitos da identidade sexual sobre a pessoa dos filhos, referida lei, ao alterar o art. $69^{\circ}$, do Código de Registo daquele país, estabeleceu que a mudança de sexo e do prenome somente será averbada no assento de nascimento dos filhos maiores da pessoa que mudou de sexo, a requerimento daqueles (art. $5^{\circ}$, da Lei $\left.\mathrm{n}^{\mathrm{o}} 7 / 2011\right) .{ }^{836}$

Assim, a regra da não averbação cede perante o interesse do registrado, manifestado após a maioridade, em averbar a mudança da identidade dos pais no próprio documento, o que se afigura uma boa solução, válida de ser trazida para o ordenamento brasileiro.

${ }_{836}$ Disponível em: <dre.pt/pdf1sdip/2011/03/05200/0145001451.pdf>, último acesso em 03/12/2011. 


\section{Conclusão}

A identificação com o gênero contrário ao sexo biológico, que caracteriza a transexualidade, provoca perplexidade. Contudo, a imposição dos fatos deixa claro que se trata de realidade enfrentada por seres humanos, atualmente expostos à violência e discriminação, vítimas de preconceito e exclusão.

As ciências da saúde, preocupadas em aliviar o sofrimento dessas pessoas, vêm progressivamente se desenvolvendo, permitindo cada vez mais aproximar a aparência da pessoa ao seu sexo de identificação. Os resultados alcançados pelas terapias hormonais e cirúrgicas têm sido positivos, significando melhoras efetivas na qualidade de vida dos transexuais.

Por outro lado, permanece a lacuna legal no Brasil, no que toca à regulação dos efeitos jurídicos da transexualidade.

Essa omissão não é irrelevante e produz consequências sérias, contribuindo para a marginalização da pessoa transexual, na medida em que a mantém invisível perante as instituições de direito de seu País, tratada como se não existisse. Acentua, também, a vulnerabilidade do transexual, na consideração de que a menos-valia resultante da omissão estatal não passa despercebida pela sociedade, acabando por fomentar a violência e a discriminação. A ausência de legislação, outrossim, estimula o preconceito e a intolerância, por revelar a incapacidade do sistema para gerir, respeitar e assimilar a diferença.

Ainda que não haja lei específica, subsiste a possibilidade de construir a proteção necessária, com base nos princípios e regras do ordenamento, mormente considerando a positivação da dignidade humana, nacional $\mathrm{e}$ internacionalmente, como viga mestra do ordenamento.

A aplicação de um princípio nunca é simples.

Sua abstração e generalidade mostram-se incompatíveis com o método subsuntivo, tornando necessária a atividade hermenêutica, sempre sujeita às críticas calcadas no subjetivismo ou ideologia do intérprete.

Para operar com princípios de modo técnico e evitar o risco de desconsideração ou banalização de tão relevantes ideais e valores, auxilia um raciocínio que demonstre, passo a passo, as etapas percorridas para alcançar a solução, permitindo ligar o fato à norma, com segurança. 
Nesse diapasão, fixada a premissa da insuficiência da positivação da dignidade humana nos documentos internacionais e nacionais e a necessidade de uma tutela mais efetiva de proteção, outros fundamentos jurídicos foram buscados.

A liberdade e a igualdade, que ao lado da dignidade fundam a República Federativa do Brasil, igualmente consistem em normas carregadas de valores, suscitando múltiplos significados.

Foram desdobradas em conteúdos mais específicos, para facilitar sua aplicação. São eles: o livre desenvolvimento da personalidade e a vida privada, em relação à liberdade, e o combate à discriminação e ao preconceito, promovendo o reconhecimento jurídico do diferente, quanto à igualdade.

Da liberdade amplamente enunciada, chegou-se a uma compreensão dinâmica da personalidade, cujo desenvolvimento pressupõe uma esfera de intimidade e de segredo, que assegure condições para escolhas pessoais voltadas ao interesse pessoal e não ao atendimento da expectativa alheia.

Por outro lado, o homem é um ser social, razão pela qual a realização no isolamento não lhe basta. Nesses termos, a tutela da pessoa não se completa sem o direito de ser respeitado e acolhido pelo grupo, reconhecendo-se a possibilidade de ser diferente, sem que isso seja causa de exclusão ou discriminação.

Tais garantias conectam-se diretamente à dignidade humana, contribuindo para sua concretização ao permitir a expansão da personalidade e a singularização do homem, como ser único e distinto dos demais, ao mesmo tempo queinserido na comunidade e reconhecido como igual parceiro de interação.

Nesse panorama, pode-se situar a opção do transexual de viver como alguém pertencente ao sexo oposto, entre as escolhas asseguradas pelo direito de liberdade. De fato, se é verdade que o conflito de identidade de gênero não depende da vontade da pessoa (ainda que não se saiba a causa precisa), não menos verdadeiro que o caminho individual trilhado a partir daí resulta da escolha própria de cada um. Como visto, há pessoas que chegam inclusive a se casar e ter filhos antes de buscar o reconhecimento da identidade de gênero, a indicar a presença da liberdade e da autonomia humanas na opção pela identidade sexual.

Tal liberdade, como todos os direitos concorrentes, encontra limites impostos pelos demais valores do ordenamento, como a dignidade da pessoa humana e a ordem pública. Assim, não se confunde com uma escolha livre do sexo, ao 
modo de um acessório, típica de uma concepção de pessoa como objeto, incompatível com a dignidade humana.

Trata-se, isto sim, de liberdade a ser exercida a partir da constatação de conflito identitário grave, designado transexualidade, próprio do transexual primário, cuja caracterização foi objeto do Capítulo II.

Feita a opção e realizada a transformação corporal em extensão suficiente para modificar a aparência e fazer crer que a pessoa pertence ao sexo oposto, não se vislumbra interesse público relevante que justifique a divulgação da realidade anterior. Enquanto o coletivo se refere ao mundo compartilhado, àquilo que nos é comum e por todos comungado, a esfera particular, em oposição, apenas diz respeito ao sujeito, assegurando-lhe um perímetro de intimidade em que a própria pessoa permite quem pode ingressar.

É exatamente o reconhecimento de que essa esfera não é do interesse geral que leva à proibição de interferência do Estado na vida privada, situando-se o sexo fisio-biológico, tanto quanto a orientação sexual e a própria sexualidade, entre os fatos protegidos pelo resguardo e pelo segredo que se completam na noção de intimidade.

Daí a distinção entre sexo e identidade sexual, que se faz necessária diante da transexualidade. O elemento biológico, que identifica e caracteriza o aparelho e os órgãos sexuais naturais, porque integrante da vida privada, é ocultado, de modo que apareça somente a identidade de gênero, relacional, construída em interação e, bem por isso, relevante para o grupo.

Afirmar que o sexo natural se insere no âmbito da vida privada e pode ser omitido da sociedade suscita a questão de como compatibilizar o interesse individual com o coletivo, na consideração de que as normas jurídicas destinadas à identificação dos membros da coletividade são de ordem pública.

É dizer, embora o sexo original restrinja-se à intimidade, a individualização de cada pessoa com base em seu nome e estado civil, familiar e político, importa ao Estado e à sociedade.

Necessário, então, harmonizar o direito da pessoa de resolver seu conflito identitário e assumir sua identidade de gênero, como expressão da liberdade, com o interesse estatal que se faz presente na correta identificação das pessoas, sem a qual não há possibilidade da segurança e certeza necessárias para a vida coletiva. 
Essa harmonização, é o que se conclui, pode ser alcançada pelo reconhecimento jurídico da identidade de gênero ou sexual, entre os direitos da personalidade.

Tal direito possui uma dimensão privada, naquilo que resulta do desenvolvimento e da expansão da personalidade, e uma dimensão pública, relativa ao estado civil, que encerra elementos de individualização e identificação da pessoa perante a sociedade.

Em sua dupla face, exprime a liberdade, voltada à autorrealização, e realiza a igualdade, ao reconhecer o direito de ser coerentemente identificado àquele cuja identidade é marcada por uma contradição. Assim, permite o tratamento igual do diferente, no pressuposto de que a negativa do reconhecimento da identidade sexual não encontra fundamento racional que o justifique e, por isso, importa em preconceito e discriminação.

Com base na constatação da estabilidade da identificação com o sexo oposto e na transformação da aparência da pessoa, cuja imagem, comportamento e modo de vida não deixam dúvidas quanto ao sexo, permitem-se as mudanças do nome e do estado, que se completam pelas respectivas alterações no Registro Civil.

A alteração registrária encerra etapa crucial desse processo, na medida em que o registro é o meio de tornar conhecida a identidade do indivíduo, tratandose de relevante instrumento para a concretização da dimensão pública da identidade de gênero ou sexual.

De fato, sem a modificação do nome e do sexo no registro fica prejudicada a realização da igualdade pelo reconhecimento da identidade de gênero.

É exatamente a exibição de documentos compatíveis com a realidade apresentada que preservará o transexual das situações vexatórias, as quais, diante do constrangimento que causam, colocam a pessoa em situação de vulnerabilidade e exposição, contribuindo para que se torne (e seja mantida) vítima de violência e discriminação.

No mais, como consignado pela Corte Europeia de Direitos Humanos ao julgar o caso paradigmático, Christine Goodwin v. Reino Unido, em 2002, as dificuldades provocadas pela mudança registral quanto ao casamento e filiação, entre outros reflexos, não são insolúveis, mas viáveis de serem contornadas, em proteção ao bem maior da vida privada, pela Corte apontado como o principal fundamento para a proteção da pessoa transexual. 
Cabe, por fim, não perder de vista que a transexualidade, de fato, desafia nossas compreensões mais básicas sobre o masculino e o feminino.

Nessa esteira, jamais se pretendeu indicar conclusões ou pontos de chegada definitivos, ainda havendo muito a percorrer no campo da definição jurídica de todas as situações postas.

Apenas que, sob o ponto de vista da dignidade da pessoa transexual e da necessidade de sua proteção contra a violência e discriminação, não há como esperar. 


\section{BIBLIOGRAFIA}

ABBAGNANO, Nicola. Dicionário de Filosofia. Tradução da primeira edição coordenada e revista por Alfredo Bosi. Revisão da tradução e tradução dos novos textos Ivone Castilho Benedetti. $4^{\mathrm{a}}$ Ed. São Paulo: Martins Fontes, 2000.

ABREU, Laura Dutra de. Transexualismo: um olhar sobre a Cirurgia de Redesignação de Sexo e seus Reflexos Jurídicos. In CAMPOS, Diogo Leite de (ORG). Estudos sobre os Direitos das Pessoas. Coimbra: Almedina, 2007, p. 123-145.

AGUIAR, Joselia. Amores Silenciados. Como a política da elite do século XIX modelou a nossa sexualidade. São Paulo: Revista de Pesquisa FAPESP, $n^{\circ} 174$, p. 82-85, agosto de 2010

ALEXY, Robert. Teoria dos Direitos Fundamentais. Tradução de Virgílio Afonso da Silva. São Paulo: Malheiros Editores, 2008.

ALMEIDA, Fernando Dias Menezes de. Liberdade de reunião. São Paulo: Max Limonad, 2001.

ALMEIDA, Guilherme Assis de. Direitos humanos e não-violência. São Paulo: Atlas, 2001 .

ALMEIDA, Susana. O respeito pela vida (privada e) familiar na jurisprudência do Tribunal Europeu dos Direitos do Homem: a tutela das novas formas de família. Coimbra: Coimbra Editora, 2008.

AMARAL, Francisco, Direito Civil. Introdução. $7^{\text {a }}$ ed. Rio de Janeiro: Renovar, 2008.

AMARAL JUNIOR, Alberto do. JUBILUT, Liliana Lyra. O Direito Internacional dos Direitos Humanos e o Supremo Tribunal Federal. In AMARAL JUNIOR, Alberto do. JUBILUT, Liliana Lyra (orgs). O STF e o Direito Internacional dos Direitos Humanos. São Paulo: Quartier Latin, 2009, p. 30-49.

AMORIM, José Roberto Neves. AMORIM, Vanda Lúcia Cintra Amorim. Direito ao nome da pessoa física. $2^{a}$ ed. Rio de Janeiro: Elsevier, 2010.

ANDORNO, Roberto. "Liberdade" e "Dignidade" da pessoa: dois paradigmas opostos ou complementares na bioética? In MARTINS-COSTA, Judith e MOLLER, Letícia Ludwig. Bioética e responsabilidade. Rio de Janeiro: Editora Forense, 2009, p. 73-93.

ANDRADE, Fábio Siebeneichler de. Considerações sobre a tutela dos direitos da personalidade no Código Civil de 2002. In O novo Código Civil e a Constituição. Ingo Wolfgang Sarlet (org). $2^{\mathrm{a}}$ ed. Porto Alegre: Livraria do Advogado, 2006, p. 101-117.

APPIO, Eduardo. Direito das minorias. São Paulo: Revista dos Tribunais, 2009.

ARAÚJO, Luiz Alberto Davi. A proteção constitucional do transexual. São Paulo: Saraiva, 2000. 
ARENDT, Hannah. A Condição Humana. Tradução de Roberto Raposo. Posfácio de Celso Lafer. 10. ed. Rio de Janeiro: Forense Universitária, 2001.

ARON, Raymond. Estudos políticos. Tradução de Sergio Bath. Brasília: Universidade de Brasília, 1985.

ASCENSÃO, José de Oliveira. A terminalidade da vida. In Martins-Costa Judith e Möller Letícia Ludwig. Bioética e Responsabilidade. Rio de Janeiro: Forense, 2009, p. 423-445.

Pessoa, Direitos Fundamentais e Direito da Personalidade.

In Estudos de Direito da Bioética, José de Oliveira Ascensão (coord), vol III. Coimbra: Almedina, 2009, p. 51-75.

Coimbra Editora, 2000.

Direito Civil. Teoria Geral. Vol. I. $2^{\mathrm{a}}$ ed. Coimbra:

BANDEIRA DE MELLO, Celso Antônio. O conteúdo jurídico do princípio da igualdade. $3^{\mathrm{a}}$ ed., $17^{\mathrm{a}}$ tiragem. São Paulo: Malheiros editora, 2009.

BARBOZA, Heloisa Helena. Princípios do biodireito, in Barboza, Heloisa Helena; Meirelles, Jussara M. L. de; Barretto, Vicente de Paulo (orgs). Novos Temas de Biodireito e bioética. Rio de Janeiro: Renovar, 2003, p. 49-81.

(org) Bioética no Brasil. Espaço e Tempo.

Direito ao corpo e doação de gametas. In Rios, André Rangel

Responsabilidade Civil em Face de Pesquisas em Seres Humanos: Efeitos do Consentimento Livre e Esclarecido. In Martins-Costa Judith e Möller Letícia Ludwig. Bioética e Responsabilidade. Rio de Janeiro: Forense, 2009, p. 205-233.

BARRETO, Vicente de Paulo. Bioética, Responsabilidade e Sociedade Técnocientífica". In MARTINS-COSTA, Judith e MOLLER, Letícia Ludwig. Bioética e responsabilidade. Rio de Janeiro: Editora Forense, 2009, p. 1-22.

BAUMAN, Zygmunt. Identidade: entrevista a Benedetto Vecchi. Tradução de Carlos Alberto Medeiros. Rio de Janeiro: Jorge Zahar Editor, 2005.

A sociedade individualizada. Vidas contadas e histórias vividas. Tradução de José Gardel. Rio de Janeiro: Jorge Zahar Editor, 2009.

BENTO, Berenice Alves de Melo. Da transexualidade oficial às transexualidades. In Piscitelli, Adriana; Gregori, Maria Filomena; Carrara, Sergio (orgs). Sexualidade e saberes: convenções e fronteiras. Rio de Janeiro: Garamond, 2004, p. 143-172.

A reinvenção do corpo: sexualidade e gênero na experiência transexual. Rio de Janeiro: Garamond, 2006.

Brasiliense, 2008

O que é transexualidade? São Paulo: Editora 
Identidade Legal de Gênero: Reconhecimento ou autorização? In COSTA, Horácio e outros (org) Retratos do Brasil Homossexual. Fronteiras, subjetividades e desejos. São Paulo: Editora da Universidade de São Paulo: Imprensa Oficial, 2010, p. 71-82.

BERLIN, Isaiah. Quatro Ensaios sobre a liberdade. Brasília: Editora UNB, 1981.

BERLINGUER, Giovanni. Questões de vida (Ética, Ciência, Saúde). Título original "Questioni di Vita: Etica,scienza, salute. Torino, Giulio Einaudi, 1991. Tradução Maria Patrícia de Sabóia Orrico e Mauro Porru. APCE-HUCITEC-CEBES: Salvador, São Paulo, Londrina: 1993.

BOBBIO, Norberto. A Era dos Direitos. Tradução de Carlos Nelson Coutinho. Apresentação de Celso Lafer. Rio de Janeiro: Elsevier, 2004.

Elogio da Serenidade e outros escritos morais. Tradução de Marco Aurélio Nogueira. São Paulo: Unesp, 2000.

Teoria Geral da Política:a filosofia política e as lições dos clássicos.

Org Michelangelo Bovero. Tradução de Daniela Beccaccia Versiani. Rio de Janeiro: Elsevier, 2000.

O Positivismo Jurídico: Lições de filosofia do direito. Tradução de Márcio Pugliesi, Edson Bini, Carlos E. Rodrigues. São Paulo: Ícone, 1995.

BOITEUX, Elza Antonia Pereira Cunha. A constante axiológica dos direitos humanos. In Benevides, Maria Victoria de Mesquita, Bercovici, Gilberto, Melo, Claudinei. Direitos Humanos, Democracia e República. Uma homenagem a Fábio Konder Comparato. São Paulo: Quartier Latin, 2009, p. 381-397.

BORBA, Marina de Neiva. Bioética e Direito: Biodireito? Dissertação de mestrado em bioética, Centro Universitário São Camilo, 2010.

BORGES, Roxana Cardoso Brasileiro. Direitos da personalidade e autonomia privada. $2^{\mathrm{a}}$ ed. São Paulo: Saraiva, 2007.

BOVERO, Michelangelo.Identità individuali e collettive. In Ricerche politiche due. Identità, interessi e scelte collettive. il Saggiatore, Milano, 1983

BUTLER, Judith. Undoing Gender. New York: Routledge, 2004.

CAMPOS, Diogo Leite de. Lições de Direitos da Personalidade. $2^{\text {a }}$ ed. Coimbra: Coimbra Editora, 1995

CANARIS, Claus-Wilhelm. Pensamento Sistemático e Conceito de Sistema na Ciência do Direito. Tradução de Menezes Cordeiro. 2a ed. Lisboa: Calouste Gulbenkian, 1996

CANÇADO TRINDADE, Antônio Augusto. Tratado Internacional de Direitos Humanos. Volume I. $2^{\text {a }}$ ed. Porto Alegre: Sergio Fabris, 2003. 
Tratado de Direito Internacional dos

Direitos Humanos, vol. II. Porto Alegre: Sergio Fabris Editor, 1999.

CAPELO DE SOUZA, Rabindranath Valentino Aleixo. O direito geral de personalidade. Coimbra: Coimbra Editora, 1995.

CASTEL, Pierre-Henri. Algumas reflexões para estabelecer a cronologia do "fenômeno transexual” (1910-1995). Revista Brasileira de História. Vol. 21. no. 41. São Paulo: 2001. Disponível em: http://dx.doi.org/10.1590/S0102-01882001000200005, último acesso em 03/01/2012.

CENEVIVA, Walter. Lei dos Registros Públicos Comentada. São Paulo: Saraiva, 1988

CHAVES, Antônio. Direito à vida e ao próprio corpo (intersexualidade, transexualidade,transplantes), $2^{\text {a }}$ Ed. São Paulo: Revista dos Tribunais, 1994.

. Castração. Esterilização. Mudança artificial de sexo. Rio de Janeiro: Revista Forense, vol. 276, ano 77, p. 2-19, out.-dez./1981.

CHILAND, Colette. O transexualismo. Tradução Maria Stela Gonçalves. São Paulo: Edições Loyola, 2008.

COMPARATO, Fabio Konder. Ética: direito, moral e religião no mundo moderno. São Paulo: Companhia das Letras, 2006.

. O direito como parte da ética. In Alves, Alaôr Caffé; Lafer, Celso; Grau, Eros Roberto; Comparato, Fábio Konder; Telles Junior, Goffredo da Silva; Ferraz Junior, Tércio Sampaio. O que é Filosofia do Direito? Barueri, SP: Manole, 2004, p. 3-10.

2001 .

A afirmação histórica dos direitos humanos. São Paulo: Saraiva,

COSTA, Jurandir Freire. "O direito à espontaneidade”. Jornal Folha de São Paulo, edição de 09/09/2010.

COUTO, Edvaldo Souza. Transexualidade: o corpo em mutação. Salvador: Editora GGB, 1999.

D’AGOSTINO, Francesco. Bioética segundo o enfoque da filosofia do direito. Tradução de Luisa Raboline. São Leopoldo, RS: Editora Unisinos, 2006.

DALLARI, Sueli Gandolfi. A proteção do Direito à intimidade, a Confidencialidade e o Sigilo na Pesquisa em Saúde. In Benevides, Maria Victoria de Mesquita, Bercovici, Gilberto, Melo, Claudinei. Direitos Humanos, Democracia e República: Homenagem a Fábio Konder Comparato - São Paulo: Quartier Latin, 2009, p. 901-926.

DICIONÁRIO HOUAISS DA LÍNGUA PORTUGUESA. $1^{\mathrm{a}}$ ed. Rio de Janeiro:Objetiva, 2001. 
DE CUPIS, Adriano. Os direitos da personalidade. Tradução de Adriano Vera Jardim e António Miguel Caeiro. Lisboa: Livraria Morais Editora, 1961.

DINIZ, Maria Helena. O estado atual do biodireito. $4^{\text {a }}$ ed. São Paulo: Saraiva, 2007.

Dicionário Jurídico. São Paulo: Saraiva, vol 4, 1998.

DURAND, Guy. Introdução Geral à bioética. História, conceitos, instrumentos. Tradução de Nicolás Nyimi Campanário. Original: Introduction générale à la bioéthique. Saint-Laurent Quebec, Canadá: Éditions Fides. São Paulo: Centro Universitário São Camilo; Loyola, $2^{\text {a }}$ Ed., 2007.

DWORKIN, Ronald. Levando os direitos a Sério. Tradução de Nelson Boeira. São Paulo: Martins Fontes, 2002.

Encyclopedia of bioethics, editado por Stephen G. Post.

ESPELETA, Lydia Buisan. Bioética y principios básicos de ética médica. In Materiales de Bioética y Derecho. Coord. María Casado. Barcelona: Cedecs Editorial S. L., 1996.

FARALLI, Carla. A filosofia do direito contemporânea: temas e desafios. Tradução de Candice Premaor Gullo. Revisão da Tradução Silvana Cobucci Leite. São Paulo: WMF Martins Fontes, 2006.

FERREIRA FILHO, Manoel Gonçalves. Aspectos do Direito Constitucional Contemporâneo. $2^{\mathrm{a}}$ ed. São Paulo: Saraiva, 2009.

referentes a tratamento médico sem transfusão de sangue.

constitucionais e legais - Direitos Humanos Fundamentais. $6^{\mathrm{a}}$ ed. São

Paulo: Saraiva, 2004.

FIORAVANTI, Carlos. Limites Incertos. Grupo de pesquisa paulista caracteriza 23 disfunções orgânicas do desenvolvimento sexual. In Revista de Pesquisa FAPESP, $\mathrm{n}^{\circ}$ 170, p. 17-21, abril de 2010 .

FONSECA, José Roberto Franco da. Dimensão internacional dos direitos fundamentais da pessoa. Revista da Faculdade de Direito da USP, nº 88, p. 487-496, 1993.

FOUCAULT, Michel. História da Sexualidade. I A vontade do saber. Tradução de Maria Thereza da Costa Albuquerque e J.A. Guilhon Albuquerque. $2^{\text {a }}$ ed. Rio de Janeiro: Edições Graal, 1979.

FLORES. Joaquín Herrera Flores. La construcción De Las Garantías. Hacia Una Concepción Antipatriarcal De La Libertad Y La Igualdad. In Sarmento, Daniel, Ikawa, Daniela e Piovesan, Flavia. Igualdade, Diferença e Direitos Humanos. Rio de Janeiro: Lúmen Juris, 2008, p. 111-145. 
FRAGOSO, Heleno Claudio. Transexualismo - cirurgia. Lesão corporal. Revista de Direito Penal, nº 25, p. 25-34. Rio de Janeiro: Editora Forense, 1979.

FRASER, Nancy. Redistribuição, Reconhecimento e Participação: Por uma Concepção Integrada de Justiça. Tradução de Bruno Ribeiro Guedes e Letícia de Campos Velho Martel In Sarmento, Daniel, Ikawa, Daniela e Piovesan, Flavia. Igualdade, Diferença e Direitos Humanos. Rio de Janeiro: Lúmen Juris, 2008, p. 167-189.

GAMA, Guilherme Calmon Nogueira da. A nova filiação: o biodireito e as relações parentais: o estabelecimento da parentalidade-filiação e os efeitos jurídicos da reprodução assistida heteróloga. Rio de Janeiro: Renovar, 2003.

GAVO, Fernandéz Javier. 10 palavras-chave em bioética. São Paulo: Paulinas, 2000

GOMES, Orlando. Introdução ao direito civil, $19^{\text {a }} \mathrm{Ed}$. Atualizada por Edvaldo Brito e Reginalda Paranhos de Brito. Rio de Janeiro: Forense, 2008.

GONÇALVES, Diogo Costa. Pessoa e Direitos da Personalidade. Fundamentação ontológica da tutela. Coimbra: Almedina, 2008.

GROENINGA, Giselle Câmara. O direito à integridade psíquica e o livre desenvolvimento da personalidade. In "Família e Dignidade Humana" - Anais do V Congresso Brasileiro de Direito de Família.

HABERMAS, Junger. O futuro da natureza humana. Tradução de Karina Jannini. São Paulo: Martins Fontes, 2004.

Direito e Democracia: entre facticidade e validade. Vol I, $2^{\mathrm{a}}$ ed. Tradução de Flavio Beno Siebeneichler. Rio de Janeiro: Tempo Brasileiro, 2003.

O discurso filosófico da modernidade. Tradução de Luiz Sérgio Repa e Rodnei Nascimento. São Paulo: Martins Fontes, 2002.

HAMMARBERG, Thomas. Human Rights and gender identity. Estrasburgo, 29/07/2009. CommDH/IssuePaper(2009), II. International Human Rights Law. Disponível em: <wcd.coe.int/ViewDoc.jsp?id=1476365>, último acesso em 02/02/2012.

HONNETH, Axel. Luta por Reconhecimento. A gramática moral dos conflitos sociais. Tradução de Luiz Repa. 2a ed. São Paulo: Editora 34, 2009.

HOTTOIS, Gilbert. Missa, Jean-Nöel. Nova enciclopédia da bioética: medicina, ambiente e biotecnologia. Tradução Maria Carvalho. Lisboa: Instituto Piaget, 2003.

HURRELL, Andrew.On global order. Power, Values, and the Constitution of International Society. Nova York: Oxford University Press, 2007.

JONAS, Hans. O princípio responsabilidade. Ensaio de uma ética para a civilização tecnológica. Tradução Marijane Lisboa e Luiz Barros Montez. Rio de Janeiro: Contraponto: Ed. PUC-Rio, 2006. 
KANT, Immanuel. Fundamentação da metafísica dos costumes. Tradução Leopoldo Holzbach. São Paulo: Martin Claret, 2003.

KLABIN, Aracy Augusta Leme. Aspectos jurídicos do transexualismo. Revista da Faculdade de Direito da Universidade de São Paulo. Vol. 90, p. 197-241, 1995.

LAFER, Celso. A reconstrução dos direitos humanos: um diálogo com o pensamento de Hannah Arendt. São Paulo: Companhia das Letras, 2003.

Filosofia do Direito e princípios gerais. In Alves, Alaôr Caffé; Lafer, Celso; Grau, Eros Roberto; Comparato, Fábio Konder; Telles Junior, Goffredo da Silva; Ferraz Junior, Tércio Sampaio. O que é Filosofia do Direito? Barueri, SP: Manole, 2004, p. 51 73.

Magnoli (org).

. Declaração Universal dos Direitos Humanos, in História da Paz, Demétrio

. Ensaios sobre a liberdade. São Paulo: Perspectiva, 1980.

.A internacionalização dos Direitos Humanos. Barueri, SP: Manole, 2005.

.Comércio, Desarmamento, Direitos Humanos. São Paulo: Paz e Terra,

1999.

. Prefácio ao livro: LINDGREN ALVES. Os direitos humanos como tema global. São Paulo: Perspectiva, 1994

Prefácio ao livro: RAMOS, Elival da Silva. Ativismo Judicial: parâmetros dogmáticos. São Paulo: Saraiva, 2010.

Desafios: ética e política. São Paulo: Siciliano, 1995.

Ensaios Liberais. São Paulo: Siciliano, 1991.

LARENZ, Karl. Metodologia da Ciência do Direito. Tradução de José Lamego. $3^{\text {a }}$ Ed. Lisboa: Fundação Calouste Gulbenkian, 1997.

LIMONGI FRANÇA. Rubens. Do nome civil das pessoas naturais. $2^{\text {a }}$ ed. São Paulo: Revista dos Tribunais, 1964.

LOBATO, Maria Inês; KOFF, Walter José; MANENTI, Carlo; SEGER, Débora da Fonseca; SALVADOR, Jaqueline; FORTES, Maria da Graça Borges; PETRY, Analídia Rodolpho; SILVEIRA, Esalba; HENRIQUES, Alexandre Annes. Follow-Up of Sex Reassignment Surgery in Transsexuals: a Brazilian Cohort, Publicação on line, Arch Sex Behav (2006) 35:711-715 DOI 10.1007/s10508-006-9074-y.

LOPES, Dulce. Principais contributos da União Europeia e do Conselho da Europa em matéria de não deiscriminação. In Periódico do CIEDA e do CIEJD, em parceria com GPE, RCE e o CEIS20. nº 4 Janeiro/Junho 2011 - Semestral. ISSN 1647-6336. Disponível 
em: http://www.europe-direct-aveiro.aeva.eu/debatereuropa/, último acesso em 26/12/2011.

LOPES, José Reinaldo Lima. O direito ao reconhecimento para gays e lésbicas. Direitos Humanos, Fundamento, Proteção e Implementação. Perspectivas e desafios contemporâneos. Vol II. Flavia Piovesan e Daniela Ikawa (coord). Curitiba: Juruá, 2008, p. $945-962$.

LOPEZ, Teresa Ancona. O dano estético. Responsabilidade civil. $3^{\text {a }}$ ed. São Paulo: RT, 2004.

LORENZETTI, Ricardo Luis. Fundamentos do direito privado. Tradução de Vera Maria Jacob de Fradera. São Paulo: Editora Revista dos Tribunais, 1998.

Teoria da Decisão Judicial. Fundamentos de Direito. Tradução de Bruno Miragem. Notas e revisão da tradução de Claudia Lima Marques. São Paulo: Editora Revista dos Tribunais, 2009.

LUCIANI, Simona. Transizioni familiari. Transessualimo, genitorialità e tutela del minore. Publicação virtual: Interattivamente. Centro di Psicologia Giuridica - Sessuologia Clinica - Psicoterapi. Disponível em: www.interattivamente.org/index.php/articoli-libri-erecensioni/58-transizioni-familiari-transessualismo-genitorialita-e-tutela-del-minore>, último acesso em 26/12/2011.

MALUF. Adriana Caldas do Rego Freitas Dabus. Casamento inexistente, nulo e anulável. in Revista do Advogado AAASP. Ano XXVIII, no 98, p. 12-37, julho de 2008.

MASCARO, Alysson Leandro. Filosofia do Direito. São Paulo: Atlas, 2010.

MATTAR, Laura Davis. Reconhecimento jurídico dos direitos sexuais - uma análise comparativa com os direitos reprodutivos. In SUR - Revista Internacional de Direitos Humanos, $\quad$ n. $\quad 8, \quad$ disponível em www.surjournal.org/conteudos/getArtigo8.php?artigo=8,port,artigo_mattar.htm, acesso em 21/09/2011.

MAZZONI, Cosimo Marco. Diritti della personalità. In Lineamenti di Diritto Privato. Mario Bessone (org). $5^{\mathrm{a}}$ ed. Torino: G. Giappichelli Editore, 2000, p. 66-72.

MELLO, Cláudio Ari. Contribuição para uma teoria híbrida dos direitos da personalidade. In $\mathbf{O}$ novo código civil e a constituiçãa. Ingo Wolfgang Sarlet (org). $2^{\mathrm{a}}$ ed. Porto Alegre: Livraria do Advogado, 2006, p. 69-100.

MENEZES CORDEIRO, António. Da boa-fé no direito civil. Coimbra: Almedina, 2001.

MEYER, Dagmar E. Estermann. Corpo, violência e educação: uma abordagem de gênero. In Diversidade Sexual na Educação: problematizações sobre a homofobia nas escolas. (Org) Junqueira, Rogério Diniz. Brasília: Ministério da Educação, UNESCO, 2009.

MILL, John Stuart. Sobre a liberdade. Tradução Pedro Madeira. Lisboa: Edições 70, 2006. 
MILLOT, Catherine. Extrasexo: ensaio sobre o transexualismo. Tradução de Maria Celeste Marcondes e Nelson Luis Barbosa. São Paulo: Escuta, 1992.

MINIUCI, Geraldo. O reconhecimento da transexualidade. Artigo publicado na $31^{\mathrm{a}}$ edição do jornal Estado de Direito, de 17/08/2011. Disponível in: www.estadodedireito.com.br/2011/08/17/o-reconhecimento-da-transexualidade/, último acesso em 03/01/2012.

MIRANDA, Jorge. Manual de Direito Constitucional, $4^{\mathrm{a}}$ ed. Tomo IV. Coimbra: Coimbra Editora, 2008.

MONTEIRO FILHO, Raphael de Barros e outros. TEIXEIRA, Sálvio de Figueiredo (coord). Comentários ao novo código civil: das pessoas. Vol I. Rio de Janeiro: Forense, 2010 .

MORAES, Maria Celina Bodin de. O princípio da dignidade humana. In Maria Celina Bodin de Moraes (coordenadora). Princípios do direito civil contemporâneo. Rio de Janeiro: Renovar, 2006, p. 1-60.

MORENO, Yolanda B. Bustos. La transexualidad (De acuerdo a la Ley 3/2007, de 15 de marzo). Madri: Editorial Dykinson, 2008.

MOTA, Júlia Cláudia Rodrigues da Cunha. O registro civil de pessoas naturais e o transexual. Rio de Janeiro: Revista Forense n 411, p. 133-156, 2010.

MOTA PINTO, Carlos Alberto da. Teoria Geral do Direito Civil. Coimbra: Coimbra Editora, 1999.

NAGEL, Thomas. Uma Breve Introdução à filosofia. Tradução de Silvana Vieira. São Paulo: Martins Fontes, 2001.

PAMPLONA DA COSTA, Ronaldo. Homossexualidade: saúde x doença. In Bioética e sexualidade. Coord. Tereza Rodrigues Vieira. São Paulo: Editora Jurídica Brasileira, 2004.

PATON. H. J. The Categorical Imperative. A study in Kant's moral philosophy. Philadelphia: University of Pennsylvania Press, 1971.

PEREIRA, Caio Mário da Silva. Instituições de Direito Civil, vol I. $20^{\text {a }}$ ed. Revista e atualizada por Maria Celina Bodin de Moraes. Rio de Janeiro: Forense, 2004.

PERES, Ana Paula Ariston Barion. Transexualismo. O direito a uma nova identidade sexual. Rio de Janeiro: Renovar, 2001.

PERES, Wiliam Siqueira. Cenas de Exclusões Anunciadas: travestis, transexuais, transgêneros e a escola brasileira. In Diversidade Sexual na Educação: problematizações sobre a homofobia nas escolas. (Org) Junqueira, Rogério Diniz. Brasília: Ministério da Educação, UNESCO, 2009. 
PERLINGIERI, Pietro. La personalità umana nell'ordinamento giuridico. Camerino: Scuola di perfezionamento in diritto civile dell'Università di Camerino, 1972.

PERONA, Javier López-Galiacho. La problemática jurídica de la transexualidad. Madri: McGrow-Hill, 1998.

PESSINI, Leocir. Barchifontaine, Christian de Paul de. Problemas atuais de bioética. $9^{\text {a }}$ Ed. São Paulo: Centro Universitário São Camilo; Loyola, 2010.

PIOVESAN, Flavia. Temas de Direitos Humanos, 3ª ed. São Paulo: Saraiva, 2009.

Direitos Humanos e Direito Constitucional Internacional. $5^{\text {a }}$ ed. São Paulo: Max Limonad, 2002.

. Direitos Humanos e Justiça Internacional. São Paulo: Saraiva, 2011

PIOVESAN, Flavia. RUSSO JUNIOR. Rômolo. Direitos Humanos, Dignidade Humana e Direitos da Personalidade. In $\mathrm{O}$ Código Civil e sua interdisciplinariedade. Os reflexos do Código Civil nos demais ramos do direito. (coord) José Geraldo Brito Filomeno e outros. Belo Horizonte: Del Rey, 2004, p. 3-19.

PONTES DE MIRANDA. Tratado de Direito Privado. Vol. VII. $2^{\mathrm{a}}$ ed. Rio de Janeiro: Editor Borsoi, 1956.

RADBRUCH, Gustav. Introdução à ciência do direito. Tradução de Vera Barkow. São Paulo: Martins Fontes, 1999.

RAMOS, Andre de Carvalho. Processo Internacional dos Direitos Humanos: análise dos sistemas de apuração de violações de direitos humanos e implementação das decisões no Brasil. Rio de Janeiro: Renovar, 2002.

2001.

Direitos Humanos em Juízo. São Paulo: Max Limonad,

RAWLS, John. Justiça como eqüidade. Uma reformulação. Tradução de Claudia Berliner. São Paulo: Martins Fontes, 2003.

RIBEIRO. Benedito Silvério. Análise de Casos que Implicam Alterações no Registro Civil. In Serviços Notariais e de Registro. Teses Apresentadas no Primeiro Simpósio Nacional de Serviços Notariais e Registrais de São Paulo, de 11 a 13 de setembro de 1996. Editado por Associação dos Notários e Registradores do Estado de São Paulo e Associação dos Serventuários de Justiça do Estado de São Paulo, p. 115-142.

RICOEUR, Paul. Percurso do Reconhecimento. Tradução de Nicolás Nyimi Campanário. São Paulo: Edições Loyola, 2006.

RIOS, Roger Raupp. Direito da Antidiscriminação, Sexo, Sexualidade e Gênero: a Compreensão da Proibição Constitucional de Discriminação por Motivo de Sexo. In Sarmento, Daniel, Ikawa, Daniela e Piovesan, Flavia. Igualdade, Diferença e Direitos Humanos. Rio de Janeiro: Lúmen Juris, 2008, p. 695-717. 
RIPOLL, Julieta Lemaitre. O amor em tempos de cólera: direitos LGBT na Colômbia. Tradução de Pedro Maia Soares. In SUR - Revista Internacional de Direitos Humanos, v. 6 , n. 11, dez 2009, p. 79/97.

RODOTÀ, Stefano. A vida na sociedade da vigilância - a privacidade hoje. Organização, seleção e apresentação de Maria Celina Bodin de Moraes. Tradução de Danilo Doneda e Luciana Cabral Doneda. Rio de Janeiro: Renovar, 2008.

Préséntation Générale des problèmes liés au transsexualisme. In

Transsexualisme, médicine e droit. Actes XXIII Colloque de droit européen. Vrije Universiteit Amsterdam (Pays-Bas) 14-16 avril, 1993, p. 23. Disponível em: <books.google.com.br/books?id=5_ludHUsN-

AC\&printsec $=$ frontcovepage $\& \mathrm{q}=$ Transsexualisme $\% 2 \mathrm{C} \% 20$ médicine $\% 20 \mathrm{et} \% 20 \mathrm{droit} \& \mathrm{f}=\mathrm{tr}$ ue>, p. 17-24 último acesso em 16/12/2011.

SÁ, Maria de Fátima Freire de; NAVES, Bruno Torquato de Oliveira. Manual de Biodireito. Belo Horizonte: Del Rey, 2009.

SAADEH, Alexandre. Transexualidade. Boletim ICAPS, n. 231, p. 1, junho de 2005.

SALES, Dimitri Nascimento. Direito à visibilidade: direito humano da população GLBTT. In PIOVESAN, Flavia. IKAWA, Daniela. (coords) Direitos humanos: fundamento, proteção e implementação. Perspectivas e desafios contemporâneos, vol II. Curitiba: Juruá, 2008, p. 927-944.

SAMPAIO, José Adércio Leite. Direito à intimidade e à vida privada. Uma visão jurídica da sexualidade, da família, da comunicação e informações pessoais, da vida e da morte. Belo Horizonte: Del Rey, 1998.

SALUM, Alejandro Nasif. Histórica declaración sobre diversidad sexual en el Consejo de Derechos Humanos de la ONU. Disponível em: www.lgbt.org.ar/00,diversidad-02.php.

SANTOS, Maria Ignez Franco. A Identidade Pessoal e a Cirurgia de Redesignação de Sexo. In CAMPOS, Diogo Leite de (ORG). Estudos sobre os Direitos das Pessoas. Coimbra: Almedina, p. 159-178.

SANTOS, Reinaldo Velloso dos. Registro Civil das Pessoas Naturais. Porto Alegre: Fabris, 2006.

SARLET, Ingo Wolfgang. Dignidade da Pessoa Humana e direitos fundamentais na Constituição Federal de 1988, $8^{\text {a }}$ Ed. Porto Alegre: Livraria do advogado editora, 2010.

SESSAREGO, Carlos Fernández. El cambio de sexo y su incidencia en las relaciones familiares. In Revista de Direito Civil, Imobiliário, Agrário e Empresarial. Ano 15, vol. 56, p. 07-56. São Paulo: Revista dos Tribunais, abril-junho/1991.

Aires: Editorial Astrea, 1992.

Abuso del derecho. Prólogo de Guillermo Borda. Buenos 
SHIELD, Sonja. "The doctor won't see you now: rights of transgender adolescents to sex reassignment treatment". Disponível em: www.law.nyu.edu/ecm_dlv4/groups/public/@nyu_law_website_law_and_social_change/d ocuments/documents/ecm_pro_064020.pdf, último acesso em 13/12/2011.

SCHREIBER, Anderson. Direitos da Personalidade. São Paulo: Atlas, 2011.

SUTTER, Matilde Josefina. Determinação e mudança de sexo - aspectos médico-legais. São Paulo: Revista dos Tribunais, 1993.

SWENSSON, Walter Cruz. NETO, Renato Swensson. SWENSSON, Alessandra Seino Granja. Lei de Registros Públicos Anotada. 4ª ed. São Paulo: Juarez de Oliveira, 2006.

SZANIAWSKY, Elimar. Limites e possibilidades do direito de redesignação do estado sexual. São Paulo: Revista dos Tribunais, 1.998.

Tribunais, 1993.

Direitos de personalidade e sua tutela. São Paulo: Revista dos

TAYLOR, Charles. As fontes do self. A construção da identidade moderna. Tradução Adail Ubirajara Sobral e Dinah de Abreu Azevedo. 2a ed. São Paulo: Edições Loyola, 2005.

TEPEDINO, Gustavo. Temas de Direito Civil. Rio de Janeiro: Renovar, $4^{\mathrm{a}}$ ed., 2008.

TEPEDINO, Gustavo; BARBOZA, Heloísa Helena; e MORAES, Maria Celina Bodin de. In Código Civil Interpretado conforme a Constituição da República. Rio de Janeiro: Renovar, 2004.

VENOSA, Sílvio de Sálvio. Direito civil: parte geral. 10ª ed. São Paulo: Atlas, 2010.

VERÇOSA, Fabiane. Comentários ao caso Christine Goodwin v. The United Kingdom. In ARQUIVOS DE DIREITOS HUMANOS, vol. 05, Renovar, 2003.

VERDE, Jole Baldaro. GRAZIOTTIN, Alessandra. Transexualismo. O enigma da identidade. Tradução Sérgio Schirato. São Paulo: Paulus, 1997.

VIEIRA, Tereza Rodrigues. A bioética e o direito à adequação do sexo do transexual. In VIEIRA, Tereza Rodrigues (coord). Bioética e Sexualidade. São Paulo: Editora Jurídica Brasileira, 2004, p. 107-122.

Reconhecimento do direito a adequação do nome e sexo de "Roberta Close". Reflexiones Bioéticas (Asociación Argentina de Bioética), Mar del Plata. Disponível em: http//www.aabioetica.org/mj1.htm.

WEIS, Bruno. No corpo certo. IstoÉ, São Paulo, 29/07/1998.

ZAGREBELSKY, Gustavo. El Derecho Dúctil. Ley, Derechos, Justicia. 5. ed. Tradução de Marina Gascón. Madrid: Editorial Trotta, 2003. 